GEOLOGICAL SURVEY CIRCULAR 926

Bibliography of Borehole

Geophysics as Applied to

Ground-Water Hydrology 

Bibliography of Borehole

Geophysics as Applied to

Ground-Water Hydrology

By Ticie A. Taylor and Joyce A. Dey

GEOLOGICAL SURVEY CIRCULAR 926 
United States Department of the Interior DONALD PAUL HODEL, Secretary

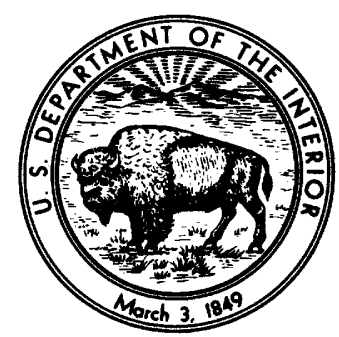

Geological Survey Dallas L. Peck, Director 


\section{CONTENTS}

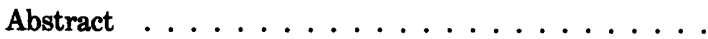

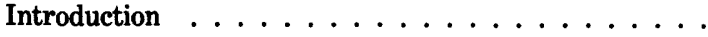

Acknowledgements ..............

Subject Headings ...............

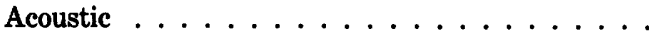

Acoustic televiewer .............

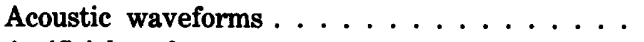

Artificial recharge $\ldots \ldots \ldots \ldots$

Borehole geophysics, general ........

Borehole geophysics, logging texts .......

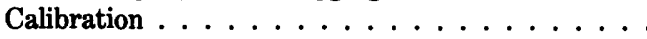

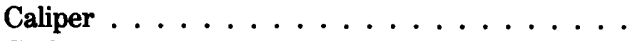

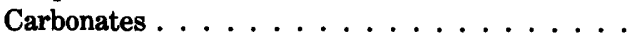

Casing and cement bond logs ........

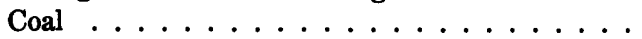

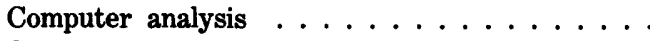

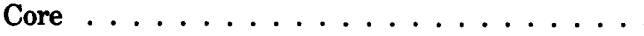

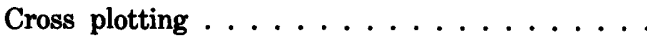

Dielectric measurements ...........

Digitizing $\operatorname{logs} \ldots \ldots \ldots \ldots \ldots$

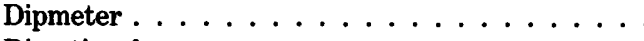

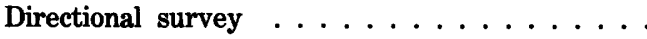

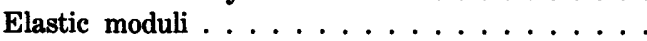

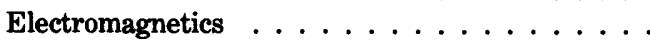

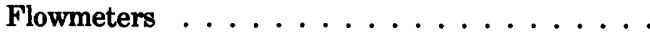

Fluid conductivity and resistivity .......

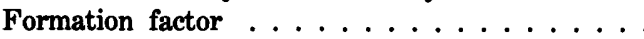

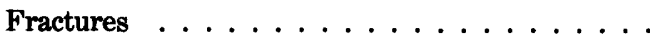

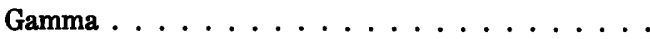

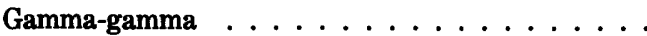

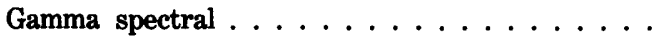

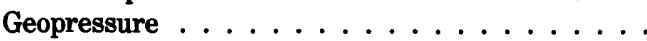

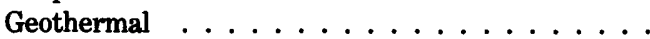

Gravimeter, borehole ............

Ground-water applications ..........

Guard $\log \ldots \ldots \ldots \ldots \ldots$

Hydraulic fracturing ............

Igneous and metamorphic rocks .........

Induced polarization
Page

1

1

2

2

2

5

5
Subject Headings-Continued Page

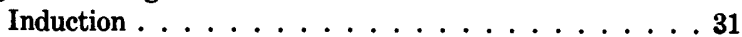

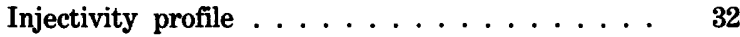

Instrumentation . . . . . . . . . . . . . . 32

Interpretation manuals ............. 32

Lithology and thickness ............ 32

Logging while drilling ............ 33

Magnetic ................. 33

Mineral exploration by logging ........ 33

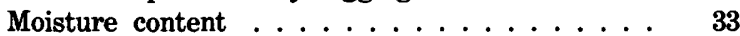

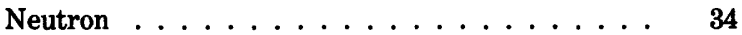

Neutron activation ........................ 37

Nuclear magnetic resonance . . . . . . . . . . . 39

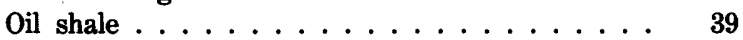

Permafrost . . . . . . . . . . . . 39

Permeability ................ 40

Petroleum production ........... 40

Porosity ................. 41

Pressure measurements ........... 42

Programs for well log analyses for hand-held calculators .................. 42

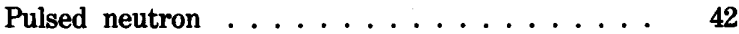

Radar ................... 43

Redox logging ............... 44

Resistivity ................. 44

Saline water problems ............ 46

Shale and clay effects ............ 46

Spontaneous potential ............ 47

Statistical methods .............. 47

Stress measurements . . . . . . . . . . . 48

Subsidence .................. 48

Television ...................... 48

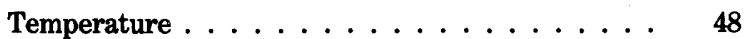

Tracers ............................. 50

Waste disposal, general ........... 51

Waste disposal, radioactive .......... 52

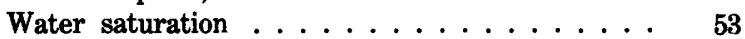

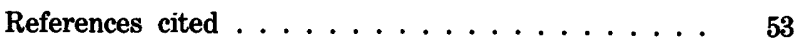

Author index ................. 55 

. 


\title{
BIBLIOGRAPHY OF BOREHOLE GEOPHYSICS AS APPLIED TO GROUND-WATER HYDROLOGY
}

\author{
By T. A. TAYLOR and J. A. DeY
}

\begin{abstract}
Most of the references on borehole geophysies that are relevant to ground-water hydrology are contained in this bibliography, but it does not include every reference that is available under each subject heading; the literature is much too extensive to compile a complete listing.

Some of the references may appear under more than one subject heading because the references commonly relate to more than one main topic. Many articles have been cross-referenced in order to assist the reader in locating an article. For example, the article entitled, "Application of the acoustic televiewer to the characterization of hydraulic fractures in geothermal wells" is listed under both "Acoustic televiewer," and "Geothermal".

The bibliography is intended to lead the reader to other articles on borehole-geophysical logging and related subjects, because each article cited also will have a list of references, which may be more specialized, covering many subjects with related applications, such as physics, mathematics, chemistry, geology, electronics, acoustics, hydrology, and surface geophysics. However, not all of these related subject headings could be included in this bibliography.
\end{abstract}

\section{INTRODUCTION}

A bibliography was developed to help Earth scientists who were having difficulty in locating and obtaining adequate information on borehole geophysics as applied to ground-water hydrology. Because many of the articles on this broad subject are published in technical journals or proceedings/ transactions that have a limited distribution, a system to categorize these publications for easy referral was developed. The U.S. Geological Survey has been developing this listing for 20 years for agency use, but the numerous requests for copies of the listing made it imperative that it be published.

The original listings subsequently have been entered into a computer, which makes it easier to modify and update by adding new articles as they become available. Furthermore, a user can quick- ly obtain a listing of references on a specific topic, or by a specific author, without searching through hundreds of pages of reference listings. Because this bibliography is stored in a computer, it can and will be updated as the need occurs.

The organization is for the users' convenience. Subject headings, as listed in the table of contents, comprise the main divisions of the publication. Author citations are listed alphabetically under each subject, giving complete title and publication data. The subject headings primarily deal with the principal method of well logging or the dominant application of the publication within the broad field of ground-water hydrology, such as waste disposal, geothermal, and oil shale, or both. An author index for the papers cited has been included at the end of this publication, as a further aid to the user.

No specific time period was established for articles to be included, but a cutoff date of July 1983 was necessary. Nor do the articles have a geographic boundary - many of the articles have been written by authors world-wide. Most of these articles are in English, or have been translated into English. However, a few articles in the original French were included, which have not been formally translated, but have been indicated by placing the label "(French)" in the listing.

The large volume of published material currently available makes it impossible for any one individual or small group to review and list all publications related to borehole geophysics as applied to ground-water hydrology. Other, professional, retrieval methods such as abstracting and indexing of journal articles (U.S. Department of Commerce, 1981) and developing computer-based storage and retrieval systems (University of Tulsa, 1983) are additional tools for meeting this need. 


\section{ACKNOWLEDGEMENTS}

Many people contributed to this bibliography; special thanks is due W. Scott Keys, Chief, Borehole Geophysics Research Project, for his many contributions, suggestions, corrections, and support. Pat Salwerowicz and Robin Simpson also deserve credit and recognition for their help in computer processing and updating.

\section{SUBJECT HEADINGS}

\section{ACOUSTIC}

Abou-Sayed, A. S., Lingle, Richard, and Jones, A. H., 1978, Sonic wave mode conversion during three-dimensional logging: American Society of Mechanical Engineers Paper 78PET-22, 4 p.

Albright, J. N., and others, 1978, Acoustic methods for detecting water-filled fractures using commercial logging tools, in Symposium on Enhanced Oil and Gas Recovery, Tulsa, Okla., 1978, Proceedings: U.S. Department of Energy, v. 1, no. F-6, p. 6/1-6/13.

Albright, J. N., and Pearson, C. F., 1980, Transmission of acoustic signals through hydraulic fractures: Society of Professional Well Log Analysts Annual Logging Symposium, 21st, Lafayette, La., 1980, Transactions, p. R1R18.

Anderson, R. A., Ingram, D. S., and Zanier, A. M., 1972, Fracture pressure gradient determination from well logs: Society of Petroleum Engineers of the American Institute of Mining, Metallurgical, and Petroleum Engineers Paper SPE 4135, 15 p.

Anderson, W. L., and Walker, Terry, 1961, Application of open hole acoustic amplitude measurements: Society of Petroleum Engineers of the American Institute of Mining, Metallurgical, and Petroleum Engineers Paper SPE 122, $6 \mathrm{p}$.

Arditty, P. C., Arens, G., and Staron, P., 1981, EVA-A long spacing sonic tool for evaluation of velocities and attenuations: Society of Exploration Geophysicists Annual Meeting, 51st, Los Angeles, Calif., 1981, Proceedings, Paper S11.1, p. 2587-2607.

Baker, L. J., 1981, The effect of the invaded zone in full waveform acoustic logging: Society of Exploration Geophysicists Annual Meeting, 51st, Los Angeles, Calif., 1981, Proceedings, Paper S11.2, p. 2609-2625.

Berezkin, V. M., 1963, The relationship between rock density and elastic wave propagation velocity: Razvedochnaya $\mathrm{i}$ Promyslovaya Geofizika, v. 49 , p. $86-87$, issued by the U.S. Department of Commerce, National Technical Information Service, Report TT-65-12825, 3 p.

Berry, J. E., 1959, Acoustic velocity in porous media: Journal of Petroleum Technology, v. 11, no. 10, p. 262-270.

Biot, M. A., 1956, Theory of propagation of elastic waves in a fluid-saturated porous solid, I-Low-frequency range; and II-Higher frequency range: Journal of the Acoustical Society of America, v. 28, no. 2, p. 168-191.

Boss, F. E., 1970, How the sonic log is used to enhance the seismic reference service velocity survey: Canadian Logging Society Journal, v. 3, no. 1, p. 17-31.
Broding, R. A., and Poole, J. L., 1960, Collection and processing of digitized acoustic log data: Geophysics, v. 25, no. 4, p. 939-947.

Brown, H. D., Grijalva, V. E., and Raymer, L. L., 1970, New developments in sonic wave train display and analysis in cased holes: Society of Professional Well Log Analysts Annual Logging Symposium, 11th, Los Angeles, Calif., 1970, Transactions, p. F1-F24.

Burke, J. A., and others, 1979, Pseudovelocity of transformation from resistivity well $\log$ data: Society of Exploration Geophysicists Annual Meeting, 49th, New Orleans, La., 1979, Proceedings, p. 1-31.

Caldwell, J. W., and Strabala, J. M., 1970, Application of modern well logging methods to salt solution cavities: Northern Ohio Geological Society Symposium on Salt, 3d, Cleveland, Ohio, 1969, Proceedings, v. 2, p. 341-352.

Carroll, R. D., 1966, Rock properties interpreted from sonic velocity logs: Proceedings of the American Society of Civil Engineers, Journal of the Soil Mechanics and Foundations Division, v. 92, no. SM2, p. 43-51.

Castagna, J. P., Anderson, Richard, and Brock, Dennis, 1981, Shear waves on sonic log waveforms: Society of Exploration Geophysicists Annual Meeting, 51st, Los Angeles, Calif., 1981, Proceedings, Paper S11.6, p. 2627-2646.

Chaney, P. E., Zimmerman, C. W., and Anderson, W. L., 1966, Some effects of frequency upon the character of acoustic logs: Journal of Petroleum Technology, v. 18, no. 4, p. 407-411.

Chang, Hsi-Tien, 1981, Acoustic cement bond logging diagnostics for geothermal applications: Geothermal Resources Council Transactions, v. 5, p. 279-282.

Cheng, C. H., and Toksoz, M. N., 1980, Modeling of full wave acoustic logs: Society of Professional Well Log Analysts Annual Logging Symposium, 21st, Lafayette, La., 1980, Transactions, p. J1-J12.

Cheng, C. H., Toksoz, M. N., and Willis, M. E., 1981, Velocity and attenuation from full waveform acoustic logs: Society of Professional Well Log Analysts Annual Logging Symposium, 22d, Mexico City, Mexico, 1981, Transactions, p. 01-019.

Christensen, M. D., 1963, The 3-D velocity log-Characteristic and use: Tulsa, Okla., Seismograph Service Corporation, Birdwell Division, 20 p.

1964, A theoretical analysis of wave propagation in fluid filled drill holes for the interpretation of 3 dimensional velocity logs: Society of Professional Well Log Analysts Annual Logging Symposium, 5th, Midland, Tex., 1964, Transactions, p. K1-K30.

1966, The determination of the in-situ elastic properties of rock salt with a 3-dimensional velocity log: Northern Ohio Geological Society Symposium on Salt, 2d, Cleveland, Ohio, 1965, Proceedings, v. 2, p. 104-115.

Core Laboratories, Inc., 1960, The continuous velocity log and acoustic core measurements: Technical Memorandum no. 16, $17 \mathrm{p}$.

Crawford, G. E., Hoyer, W. A., and Spann, M. M., 1973, Frequency response and resonance in acoustic logging: Log Analyst, v. 14, no. 1, p. 3-15.

Evans, H. B., and Cotterell, C. H., 1967, Synthesis of modulus logs from acoustic parameters_-Some preliminary results: Society of Professional Well Log Analysts Annual Logging Symposium, 8th, Denver, Colo., 1967, Transactions, p. AA1-AA33. 
Fehler, M. C., and Pearson, C. F., 1981, Acoustic radiation patterns for borehole sources: Society of Professional Well Log Analysts Annual Logging Symposium, 22d, Mexico City, Mexico, 1981, Transactions, p. MM1-MM17.

Feves, Michael, Simmons, Gene, and Siegfried, R. W., 1977, Microcracks in crustal igneous rocks-Physical properties, in Earth's crust: American Geophysical Union, issued by the U.S. Department of Commerce, National Technical Information Service, Report ADA078984, p. 95-117.

Froelich, Benoit, Pittman, Dennis, and Seeman, Bruno, 1981, Cement evaluation tool-A new approach to cement: Society of Petroleum Engineers of the American Institute of Mining, Metallurgical, and Petroleum Engineers Paper SPE 10207, 9 p.

Gardner, G. H. F., and Harris, M. H., 1968, Velocity and attentuation of elastic waves in sands: Society of Professional Well Log Analysts Annual Logging Symposium, 9th, New Orleans, La., 1968, Transactions, p. M1-M19.

Gardner, G. H. F., Wyllie, M. R. J., and Droschak, D. M., 1964, Effects of pressure and fluid saturation on the attenuation of elastic waves in sands: Journal of Petroleum Technology, v. 16, no. 2, p. 189-198.

Geyer, R. L., and Myung, J. I., 1970, The 3-D velocity log-A tool for in-situ determination of elastic moduli of rocks: Tulsa, Okla., Seismograph Service Corporation, Birdwell Division, $36 \mathrm{p}$.

Gowd, T. N., and Rummel, F., 1980, Effect of confining pressure on fracture behavior of a porous rock: International Journal of Rock Mechanics, Mineral Sciences, and Geomechanics Abstracts, v. 17, p. 225-229.

Gratsinskiy, V. G., 1969, Fast-response equipment for acoustic logging: Lenningrad, USSR, Izvestiya, Earth Physics, no. 12, December, p. 62-72.

Gregory, A. R., 1965, Ultrasonic pulsed-beam transmission and reflection methods for measuring rock propertiesSome theoretical and experimental results: Society of Professional Well Log Analysts Annual Logging Symposium, 6th, Dallas, Tex., 1965, Transactions, p. B1-B17.

Guy, J. O., Youmans, A. H., and Smith, W. D. M., 1971, The sidewall acoustic neutron log: Society of Professional Well Log Analysts Annual Logging Symposium, 12th, Dallas, Tex., 1971, Transactions, p. X1-X16.

Guyod, Hubert, and Shane, L. E., 1969, Geophysical well logging - Introduction to geophysical well logging; acoustical logging: Houston, Tex., Hubert Guyod, 256 p.

Hartley, K. B., 1981, Factors affecting sandstone acoustic compressional velocities and an examination of empirical correlations between velocities and porosities: Society of Professional Well Log Analysts Annual Logging Symposium, 22d, Mexico City, Mexico, 1981, Transactions, p. PP1-PP21.

Hoffard, S. H., 1980, Feasibility of using an acoustic velocity meter to measure flow in the Chipps Island Channel, Suisun Bay, California: U.S. Geological Survey Open-File Report 80-697, 33 p.

Jankowsky, W., 1969, Empirical investigation of some factors affecting elastic wave velocities in carbonate rocks: European Association of Exploration Geophysicists Meeting, 31st, Venice, Ițaly, 1969, Proceedings, p. 103-118.

Khalevin, N. I., 1960, Measurement of rock porosity by sonic well logging: Razvedochnaya i Promyslovaya Geofizika, v. 30, p. 3-9, and Glen Ridge, N. J., Associated Technical Services, Inc., 5 p.
Kithas, B. A., 1976, Lithology, gas detection, and rock properties from acoustic logging systems: Society of Professional Well Log Analysts Annual Logging Symposium, 17th, Denver, Colo., 1976, Transactions, p. R1-R15.

Kitsunezaki, Choro, 1980, A new method for shear-wave logging: Geophysics, v. 45, no. 10, p. 1489-1506.

Kokesh, F. P., and Blizard, R. B., 1959, Geometrical factors in sonic logging: Geophysics, v. 24, no. 1, p. 64-76.

Kokesh, F. P., and others, 1964, A new approach to sonic logging and other acoustic measurements: Society of Petroleum Engineers of the American Institute of Mining, Metallurgical, and Petroleum Engineers Paper SPE 991, $11 \mathrm{p}$.

Lingle, Richard, and Jones, A. H., 1977, Comparison of log and laboratory measured $\mathrm{P}$-wave and $\mathrm{S}$-wave velocities: Society of Professional Well Log Analysts Annual Logging Symposium, 18th, Houston, Tex., 1977, Transactions, p. N1-N12.

McCann, D. M., and McCann, Clive, 1977, The application of borehole acoustic logging techniques in engineering geology: Log Analyst, v. 18, no. 3, p. 30-37.

McCoy, J. N., 1962, Analyzing well performance: Society of Petroleum Engineers of the American Institute of Mining, Metallurgical, and Petroleum Engineers Paper SPE 337, $15 \mathrm{p}$.

Millican, M. L., 1959, The sonic log and the Delaware sand: Society of Petroleum Engineers of the American Institute of Mining, Metallurgical, and Petroleum Engineers Paper $1251-\mathrm{G}, 4 \mathrm{p}$.

Morris, R. L., Grine, D. R., and Arkfeld, T. E., 1963, The use of compressional and shear acoustic amplitudes for the location of fractures: Society of Petroleum Engineers of the American Institute of Mining, Metallurgical, and Petroleum Engineers Paper SPE 723, 13 p.

Muir, D. M., and Latson, B. F., 1962, Oscillographs of acoustic energy and their application to log interpretation: Houston, Tex., Pan Geo Atlas Corp., 11 p.

Muir, D. M., and Zoeller, W. A., 1967, New acoustic tool logs cased holes: Oil and Gas Journal, v. 65, no. 43, p. 106-111.

Myers, A. J., 1963, Sonar measurements of brine cavity shapes: Northern Ohio Geological Society Symposium on Salt, 1st, Cleveland, Ohio, 1962, Proceedings, p. 546-554.

Myung, J. I., and Baltosser, R. W., 1972, Fracture evaluation by the borehole logging method: U.S. National Committee on Rock Mechanics Annual Symposium, 13th, Urbana, Ill., 1972, Proceedings, p. 31-56.

Myung, J. I., and Helander, D. P., 1974, Borehole investigation of rock quality and deformation using the $3-D$ velocity log: Northern Ohio Geological Society Symposium on Salt, 4th, Houston, Tex., 1974, Proceedings, v. 2, p. 141-152.

Narasimhan, T. N., Houston, W. N., and Nur, A. M., 1980, The role of pore pressure in deformation in geologic processes: Geology, v. 8, p. 349-351.

Nolte, Ernest, 1968, Sonar tool surveys under-ground cavities: Oil and Gas Journal, v. 66, no. 38, p. 76-78.

Norel, Guy, 1974, Ultrasonic logging techniques: Society of Professional Well Log Analysts European Symposium, 3d, London, England, 1974, Transactions, p. C1-C11.

Norel, Guy, and Desbrandes, Robert, 1973, Une nouvelle diagraphie des sondages par reflexion ultrasonique [A new logging method using ultrasonic reflection]: Revue De L'Institut Francais Du Petrole, v. 28, no. 4, p. 587-604. 
Omnes, Gildas, 1979, Logs from P and S vertical seismic profiles: Society of Petroleum Engineers of the American Institute of Mining, Metallurgical, and Petroleum Engineers Paper SPE 8364, 7 p.

Overton, H. L., and Smith, Dale, 1966, Acoustic travel time in cored basalt: Log Analyst, v. 7, no. 2, p. 25-28.

Park, H. S., and Roetman, E. L., 1980, Transmission of acoustical signals through porous media: Society of Petroleum Engineers of the American Institute of Mining, Metallurgical, and Petroleum Engineers Paper SPE 9090, 22 p.

Paulsson, B. N. P., and King, M. S., 1980, Ultrasonic and acoustic emission results from the Stripa heater experiments, part I-A cross-hole investigation of a rock mass subjected to heating: Swedish Nuclear Fuel Supply Company and Lawrence Berkeley Laboratory, issued by the U.S. Department of Commerce, National Technical Information Service, Report LBL-10975, p. 1-26.

Pickett, G. R., 1960, The use of acoustic logs in the evaluation of sandstone reservoirs: Geophysics, v. 25 , no. 1, p. 250 274.

1963, Acoustic character logs and their applications in formation evaluation: Journal of Petroleum Technology, v. 15 , no. 6 , p. $659-667$.

Pickett, G. R., and Reynolds, E. B., 1969, Evaluation of fractured reservoirs: Society of Petroleum Engineers Journal, v. 9, no. 1, p. 28-38.

Rachiele, R., 1980, Ultrasonic and acoustic emission results from the Stripa heater experiments, part II-Acoustic emission monitoring during cool-down of the Stripa heater experiment: Swedish Nuclear Fuel Supply Company and Lawrence Berkeley Laboratory, issued by the U.S. Department of Commerce, National Technical Information Service, Report LBL-10975, p. 27-29.

Rechtien, R. D., 1970, A high frequency wave generator for application to cavity delineation: Northern Ohio Geological Society Symposium on Salt, 3d, Cleveland, Ohio, 1969, Proceedings, v. 2, p. 357-366.

Reynolds, E. B., Timko, D. J., and Zanier, A. M., 1972, Potential hazards of acoustic log-shale pressure plots: Society of Petroleum Engineers of the American Institute of Mining, Metallurgical, and Petroleum Engineers Paper SPE 4020, $8 \mathrm{p}$.

Robinson, W. S., 1975, Field results-Noise logging techniques: Baroid News Bulletin, v. 26, no. 1, p. 10-15.

Runge, R. J., and Powell, N. J., 1967, The effect of sampling rate on sonic log span adjustment: Society of Professional Well Log Analysts Annual Logging Symposium, 8th, Denver, Colo., 1967, Transactions, p. D1-D19.

Schoenberg, Michael, and others, 1981, Space-time dependence of acoustic waves in a borehole: Journal of the Acoustical Society of America, v. 70, no. 5, p. 1496-1507.

Scott, J. H., 1981, Tests of a hole-to-hole acoustic pulse measurement system: U.S. Geological Survey Open-File Report 81-1087, 22 p.

Scott, J. H., and Sena, Joe, 1974, Acoustic logging for mining applications: Society of Professional Well Log Analysts Annual Logging Symposium, 15th, McAllen, Tex., 1974, Transactions, p. P1-P11.

Seismic Service Corporation, 1971, Borehole U-3 JF, Nevada Test Site, interval velocity determination: Tulsa, Okla., Birdwell Division, 12 p.
Shane, L. E., 1970, Attentuation of acoustic logging signals: Log Analyst, v. 11, no. 6, p. 3-10.

Shanks, R. T., and others, 1976, A review of fracture detection with well logs: Society of Petroleum Engineers of the American Institute of Mining, Metallurgical, and Petroleum Engineers Paper SPE 6159, 16 p.

Shirley, D. J., and Anderson, A. L., 1975, In situ measurements of marine sediment acoustical properties during coring in deep water: Institute of Electrical and Electronics Engineers, Transactions on Geoscience Electronics, v. GE-13, no. 4, p. 163-169.

Shuck, L. Z., and Keech, R. W., 1974, Noise characteristics of oil wells and reservoirs: Society of Petroleum Engineers of the American Institute of Mining, Metallurgical, and Petroleum Engineers Paper SPE 5147-B, 12 p.

Stierman, D. J., Healy, J. H., and Kovach, R. L., 1979, Pressure-induced velocity gradient-An alternative to a $\mathrm{Pg}$ refractor in the Gabilan Range, central California: Bulletin of the Seismological Society of America, v. 69, no. 2, p. $397-415$.

Stierman, D. J., and Kovach, R. L., 1979, An in situ velocity study -The Stone Canyon well: Journal of Geophysical Research, v. 84 , no. B2, p. $672-678$.

Stierman, D. J., and Zappe, S. O., 1981, Lateral P-velocity gradients near major strike-dip faults in California: Science, v. 213 , no. 4504 , p. 207-209.

Stripling, A. A., 1958, Velocity log characteristics: American Institute of Mining, Metallurgical, and Petroleum Engineers Transactions, v. 213, p. 207-212.

Suhler, S. A., Winnie, D. D., and Owen, T. E., 1974, A laboratory model dry-hole velocity probe and permissible system design for operation in coal mines: Southwest Research Institute Final Technical Report, 73 p., issued by the U.S. Bureau of Mines.

Tatham, R. H., 1982, $V_{p} / V_{s}$, and lithology: Geophysics, v. 47, no. 3, p. 336-344.

Thurber, C. H., 1957, Velocity surveys aid in seismic interpretation: World Oil, v. 145 , no. 6 , p. $78-82$.

1959, geoacoustic spectrum: Oil and Gas Journal, v. 57, no. 42 , p. 228-236.

1961, Acoustic log integration: Houston, Tex., Pan Geo Atlas Corporation, PGAC Service Report, 3 p.

Thurber, C. H., and Latson, B. F., 1960, Acoustic log checks casing cement jobs: Petroleum Engineer, v. 32, no. 13, p. B84, B88.

Timur, Aytekin, 1978, Rock physics: The Arabian Journal for Science and Engineering, Special Issue, p. 5-30.

Timur, Aytekin, and others, eds., 1978, Acoustic logging (reprint volume): Houston, Tex., Society of Professional Well Log Analysts, $341 \mathrm{p}$.

Tixier, M. P., Alger, R. P., and Doh, C. A., 1959, Sonic logging: Journal of Petroleum Technology, v. 11, no. 5, p. 106-114.

Tixier, M. P., Alger, R. P., and Tanguy, D. R., 1960, New developments in induction and sonic logging: Journal of Petroleum Technology, v. 12, no. 5, p. 79-87.

Tixier, M. P., Loveless, G. W., and Anderson, R. A., 1973, Estimation of formation strength from the mechanical properties log: Journal of Petroleum Technology, v. 27, no. 3, p. 283-293. 
Vogel, C. B., and Herolz, R. A., 1977, The CAD, a circumferential acoustical device for well logging: Society of Petroleum Engineers of the American Institute of Mining, Metallurgical, and Petroleum Engineers Paper SPE 6819, 5 p.

Walker, Terry, 1964, The interpretation of the fracture finding micro-seismogram log: Society of Professional Well Log Analysts Annual Logging Symposium, 5th, Midland, Tex., 1964, Transactions, p. I1-I7.

Welex Division, 1965, Some factors affecting acoustic measurements: Houston, Tex., Halliburton Company, Technical Tips and Techniques no. 4, 12 p.

White, J. E., 1967, The Hula Log-A proposed acoustic tool: Society of Professional Well Log Analysts Annual Logging Symposium, 8th, Denver, Colo., 1967, Transactions, p. I1I25.

Wiercinski, G. M., 1978, The acoustical determination of cement sheath thickness in cased oil wells [University of Oklahoma, Ph. D. dissertation]: University Microfilms, International, Publication 781923, $91 \mathrm{p}$.

Wylie, K. M., 1968, Seismic analysis-The bit breakthrough in ripping rock: Testing World, no. 22, p. 4-5.

Yu, T. R., and Telford, W. M., 1973, An ultrasonic system for fracture detection in rock faces: Canadian Institute of Mining and Petroleum Engineers Transactions, v. 66, no. 729, p. 96-101.

Zanier, A. M., and Overton, H. L., 1970, Use of acoustic logging technique for determination of intergrain cementation properties: Society of Professional Well Log Analysts Annual Logging Symposium, 11th, Los Angeles, Calif., 1970, Transactions, p. K1-K11.

Zhadin, V. V., 1960, The study of attenuation of longitudinal and transverse waves by means of the seismic logging methods: Geologiya i Geofizika, no. 3, p. 80-93, and Glen Ridge, N. J., Associated Technical Services, Inc., 14 p.

Zoeller, W. A., 1966, Dual porosity logging-A means to better evaluation of porosity in the Permian Basin: Log Analyst, v. 6, no. 5, p. 50-59.

\section{ACOUSTIC TELEVIEWER}

Broding, R. A., 1981, Volumetric scanning well logging: Society of Professional Well Log Analysts Annual Logging Symposium, 22d, Mexico City, Mexico, 1981, Transactions, p. B1-B17.

Glenn, E. E., and others, 1971, New borehole televiewer can be run through tubing: World Oil, v. 172 , no. 1, p. $63-65$.

Jageler, A. H., 1980, New well logging tools improve formation evaluation: World Oil, v. 190 , no. 4 , p. 89-103.

Keys, W. S., 1979, Borehole geophysics in igneous and metamorphic rocks: Society of Professional Well Log Analysts Annual Logging Symposium, 20th, Tulsa, Okla., 1979, Transactions, p. 001-0026.

1980, Application of the acoustic televiewer to the characterization of hydraulic fractures in geothermal wells: Geothermal Reservoir Stimulation Symposium, San Francisco, Calif., 1980, Proceedings, p. 176-202.

Keys, W. S., and others, 1979, In situ stress measurements near the San Andreas Fault in central California: Journal of Geophysical Research, v. 84, no. B4, p. 1583-1591.
Keys, W. S., and Sullivan, J. K., 1979, Role of borehole geophysics in defining the physical characteristics of the Raft River geothermal reservoir, Idaho: Geophysics, v. 44 , no. 6 , p. 1116-1141.

Schaller, H. E., Kilpatrick, Robert, and Stratton, Robert, 1972, The acoustiviewer-A new method for inspection of down-hole tubular goods: Society of Petroleum Engineers of the American Institute of Mining, Metallurgical, and Petroleum Engineers Paper SPE 4000, 5 p.

Wiley, Ralph, 1980, Borehole televiewer-Revisited: Society of Professional Well Log Analysts Annual Logging Symposium, 21st, Lafayette, La., 1980, Transactions, p. HH1HH16.

Wonn, J. W., 1979, Development of an acoustic sensor for a geothermal borehole televiewer: U.S. Department of Energy, issued by the U.S. Department of Commerce, National Technical Information Service, Report ALO-5391T2, 264 p.

Zemanek, Joseph, and others, 1969, The borehole televiewerA new logging concept for fracture location and other types of borehole inspection: Journal of Petroleum Technology, v. 21, no. 6, p. 762-774.

1970, Formation evaluation by inspection with the borehole televiewer: Geophysics, v. 35, no. 2, p. 254-269.

Zoback, M. D., and Anderson, R. N., 1982, Ultrasonic borehole televiewer investigation of oceanic crustal layer 2A, Costa Rica Rift: Nature, v. 295, p. 375-379.

\section{ACOUSTIC WAVEFORMS}

Chen, S. T., 1982, The full acoustic wave train in a laboratory model of a borehole: Geophysics, v. 47, no. 11, p. 15121520 .

Cheng, C. H., and Toksoz, M. N., 1982, Generation, propagation and analysis of tube waves in a borehole: Society of Professional Well Log Analysts Annual Logging Symposium, 23d, Corpus Christi, Tex., 1982, Transactions, p. P1-P20.

Fons, Lloyd, 1963, Acoustic scope pictures: Society of Petroleum Engineers of the American Institute of Mining, Metallurgical, and Petroleum Engineers Paper SPE 724, $12 \mathrm{p}$.

Gladwin, M. T., and Stacey, F. D., 1974, An elastic degradation of acoustic pulses in rock: Physics of the Earth and Planetary Interiors, v. 8, p. 332-336.

Grady, D. E., Hollenbach, R. E., and Schuler, L. W., 1978, Compression wave studies on calcite rock: Journal of Geophysical Research, v. 83, no. B6, p. 2839-2849.

Gregory, A. R., Kendall, K. K. and Lawal, A. S., 1980, Study effects of geopressured-geothermal subsurface environment on elastic properties of Texas Gulf Coast sandstones and shales using well logs, core data, and velocity surveys: University of Texas, issued by the U.S. Department of Commerce, National Technical Information Service, Report DOE/ET/28468-T1, 170 p.

Huang, C. F., and Hunter, J. A., 1980, Identification and correlation of tube wave vents shown on borehole seismograms: Chalk River, Ontario, Atomic Energy of Canada Limited, Scientific Documentation Distribution Office, Technical Record TR $\_32,14 \mathrm{p}$. 
1981, The correlation of tube wave events with open fractures in fluid-filled boreholes: Chalk River, Ontario, Atomic Energy of Canada Limited, Scientific Documentation Distribution Office, Technical Record TR-162, 41 p.

Johnston, D. H., and Toksoz, M. N., 1980, Thermal cracking and amplitude dependent attenuation: Journal of Geophysical Research, v. 85, no. B2, p. 937-942.

Jones, A. H., and others, 1977, Rock mechanics studies related to massive hydraulic fracturing of eastern United States Devonian shales: Salt Lake City, Utah, TerraTek, Inc., Report TR77-16, 72 p.

Kjartansson, Einar, 1979, Constant Q-wave propagation and attenuation: Journal of Geophysical Research, v. 84, no. B9, p. 4737-4747.

Koerperich, E. A., 1977, Investigation of acoustic boundary waves and interference patterns as techniques for detecting fractures: Society of Petroleum Engineers of the American Institute of Mining, Metallurgical, and Petroleum Engineers Paper SPE 6820, 12 p.

1979, Shear wave velocities determined from long and short spaced borehole acoustic devices: Society of Petroleum Engineers of the American Institute of Mining, Metallurgical, and Petroleum Engineers Paper SPE 8237, $12 \mathrm{p}$.

Lebreton, F., and others, 1978, Logging tests in porous media to evaluate the influence of their permeability on acoustic waveforms: Society of Professional Well Log Analysts Annual Logging Symposium, 19th, El Paso, Tex., 1978, Transactions, p. Q1-Q25.

Lytle, R. J., and Portnoff, M. R., 1982, Cross-borehole seismic probing to locate high-contrast anomalies: Lawrence Livermore Laboratory, issued by the U.S. Department of Commerce, National Technical Information Service, Report UCID-19247, 54 p.

McKenzie, C. K., Stacey, G. P., and Gladwin, M. T., 1982, Ultrasonic characteristics of a rock mass: International Journal of Rock Mechanics, Mineral Sciences, and Geomechanics Abstracts, v. 19, p. 25-30.

Nations, J. F., 1974, Lithology and porosity from acoustic shear and compressional wave transit time relationships: Log Analyst, v. 15, no. 6, p. 3-8.

Nur, A. M., and others, 1979, Effects of fluid saturation on waves in porous rock and relation to hydraulic permeability: Society of Petroleum Engineers of the American Institute of Mining Metallurgical, and Petroleum Engineers Paper SPE 8235, 8 p.

Ohta, Y., and others, 1980, S-wave velocity measurements in deep soil deposit and bedrock by means of an elaborated down-hole method: Bulletin of the Seismological Society of America, v. 70, no. 1, p. 363-377.

Paillet, F. L., 1980, Acoustic propagation in the vicinity of fractures which intersect a fluid-filled borehole: Society of Professional Well Log Analysts, Annual Logging Symposium, 21st, Lafayette, La., 1980, Transactions, p. DD1DD33.

1981, Predicting the frequency content of acoustic waveforms obtained in boreholes: Society of Professional Well Log Analysts Annual Logging Symposium, 22d, Mexico City, Mexico, 1981, Transactions, p. SS1-SS29.
Rader, Dennis, 1982, Acoustic logging-The complete waveform and its interpretation, in Fitch, A. A., ed., Developments in geophysical exploration methods-3: London, England, Elsevier Applied Science Publishers, p. 151-193.

Ramananantoandro, R., 1979, Estimation of the dispersion of compressional waves in rocks from ultrasonic to seismic frequencies: Journal of Geophysics, v. 46, p. 451-454.

Rechtien, R. D., 1970, A high frequency wave generator for application to cavity delination: Northern Ohio Geological Society Symposium on Salt, 3d, Cleveland, Ohio, 1969, Proceedings, v. 2, p. 357-366.

Setser, G. G., 1982, Fracture detection by circumferential propagation of acoustic energy: Society of Petroleum Engineers of the American Institute of Mining, Metallurgical, and Petroleum Engineers Paper SPE 10204, 8 p.

Siegfried, R. W., and Castagna, J. P., 1982, Full waveform sonic logging techniques: Society of Professional Well Log Analysts Annual Logging Symposium, 23d, Corpus Christi, Tex., 1982, Transactions, p. I1-I25.

Smith, P. G., and Greenkorn, R. A., 1971, Theory of acoustical wave propagation in porous media: Journal of the Acoustical Society of America, v. 52, no. 1, p. 247-253.

Spencer, J. W., Jr., 1979, Bulk and shear attenuation in Berea sandstone-The effects of pore fluids: Journal of Geophysical Research, v. 84, no. B13, p. 7521-7523.

Staal, J. J., and Robinson, J. D., 1977, Permeability profiles from acoustic logging: Society of Petroleum Engineers of the American Institute of Mining, Metallurgical, and Petroleum Engineers Paper SPE 6821, 4 p.

Stephansson, Ove, Lande, G., and Bodare, A., 1979, A seismic study of shallow jointed rocks: International Journal of Rock Mechanics, Mineral Sciences, and Geomechanics Abstracts, v. 16, no. 5, p. 319-327.

Stokoe, K. H., and Woods, R. D., 1972, In situ shear wave velocity by cross-hole method: Proceedings of the American Society of Civil Engineers, Journal of Soil Mechanics and Foundations Division, v. 98, no. SM5, p. $443-460$.

Stoll, R. D., 1979, Experimental studies of attenuation in sediments: Journal of the Acoustical Society of America, $v$. 66 , no. 4, p. $1152-1160$.

Toksoz, M. N., and Cheng, C. H., 1978, Modeling of seismic velocities in porous rocks and its application to seismic exploration: The Arabian Journal for Science and Engineering, Special Issue, p. 109-131.

Walker, Terry, and Riddle, George, 1963, Field investigation of full wave recording of the acoustic signal: Log Analyst, v. 4, no. 1, p. 1-24.

Waters, K. H., Palmer, S. P., and Farrell, W. E., 1978, Fracture detection in crystalline rock using ultrasonic shear waves: Lawrence Berkeley Laboratory, issued by the U.S. Department of Commerce, National Technical Information Service, Report LBL-7051, 45 p.

\section{ARTIFICIAL RECHARGE}

Keys, W. S., and Brown, R. F., 1971, The use of well logging in recharge studies of the Ogallala Formation in west Texas, in Geological Survey Research 1971: U.S. Geological Survey Professional Paper 750-B, p. B270-B277. 
1978, The use of temperature logs to trace the movement of injected water: Ground Water, v. 16, no. 1, p. 32-48.

Reeder, H. O., and others, 1976, Artificial recharge through a well in fissured carbonate rock, West St. Paul, Minnesota: U.S. Geological Survey Water-Supply Paper 2004, 80 p.

Schneider, A. D., Jones, O. R., and Signor, D. C., 1971, Recharge of turbid water to the Ogallala aquifer through a dual-purpose well: College Station, Tex., Texas A \& M University, Texas Agricultural Experiment Station Publication MP-1001, $10 \mathrm{p}$.

Signor, D. C., and Hauser, V. L., 1968, Artificial ground water recharge through basins in the Texas High Plains: College Station, Tex., Texas A \& M University, Texas Agricultural Experiment Station Publication MP-895, 8 p.

\section{BOREHOLE GEOPHYSICS, GENERAL}

Aguilera, Roberto, 1979, Uncertainty in log calculations can be measured: Oil and Gas Journal, v. 77 , no. 37, p. 126128.

Aguilera, Roberto, and van Poolen, H. K., 1979, Choice of completion method affects productivity: Oil and Gas Journal, v. 77, no. 8, p. 106-108.

Alger, R. P., 1960, Modern logging programs and interpretation methods in Formation Evaluation Symposium, Houston, Tex., 1960, Proceedings: Dallas, Tex., Society of Petroleum Engineers of the American Institute of Mining, Metallurgical, and Petroleum Engineers p. II59-II82.

1962, Interpretation of the Dakota sandstone of the San Juan Basin: Society of Professional Well Log Analysts Annual Logging Symposium, 3d, Houston, Tex., 1962, Transactions, p. 1-19.

Alger, R. P., and Crain, E. R., 1966, Defining evaporite deposits with electric well logs: Northern Ohio Geological Society Symposium on Salt, 2d, Cleveland, Ohio, 1965, Proceedings, v. 2, p. 116-130.

Amato, R. V., and Bebout, J. W., 1978, Geological and operational summary, COST no. GE-1 well, Southeast Georgia Embayment area, South Atlantic OCS: U.S. Geological Survey Open-File Report 78-668, 122 p.

Anderson, W. B., 1964, Potential uses for borehole logs in mineral exploration: Canadian Institute of Mining and Metallurgy Bulletin, v. 67 , no. 743 , p. 164-168.

Baltosser, R. W., and Lawrence, H. W., 1970, Application of well logging techniques in metallic mineral mining: Geophysics, v. 35, no. 1, p. 143-152.

Bardsley, S. R., and Algermissen, S. T., 1963, Evaluating oil shale by $\log$ analysis: Quarterly of the Colorado School of Mines, v. 58, no. 4, p. 175-184.

Barlai, Zoltan, 1970, Some principal questions of well logging evaluation of hydrocarbon-bearing sandstones with a high silt and clay content-Experience gained by the field application of a new method: Society of Professional Well Log Analysts Annual Logging Symposium, 11th, Los Angeles, Calif., 1970, Transactions, p. 01-064.

Barsukov, 0. A., and others, 1965, Radioactive investigations of oil and gas wells: New York, Macmillan, $299 \mathrm{p}$.

Bicker, A. R., Jr., and Mellen, F. F., 1964, Well logging by Mississippi Geological Survey: Mississippi Geological Survey Bulletin 104, p. 111-127.
Bird, J. M., 1966, Well log applications and interpretation in a brine field: Northern Ohio Geological Society Symposium on Salt, 2d, Cleveland, Ohio, 1965, Proceedings, v. 2, p. $57-69$.

Blankennagel, R. K., 1968, Geophysical logging and hydraulic testing, Pahute Mesa, Nevada Test Site: Ground Water, v. 6 , no. 4, p. 24-31.

Bosworth, A. F., 1966, Logging techniques in the oil industry, in Drilling for scientific purposes: International Upper Mantle Symposium, Ottawa, Ontario, 1965, Geological Survey of Canada Paper 66-13, p. 58-73.

Breitenbach, E. A., 1965, A new technique for approximating drilling fluid filtration: Society of Professional Well Log Analysts Annual Logging Symposium, 6th, Dallas, Tex., 1965, Transactions, p. I1-I12.

Brown, D. L. and others, 1977, Preliminary data for Madison Limestone test well no. 2, $\mathrm{SE}^{1 / 4 \mathrm{SE}^{1 / 4}}$ sec. 18 , T. $1 \mathrm{~N}$., R. 54 E., Custer County, Montana: U.S. Geological Survey Open-File Report 77-863, 134 p.

Brown, H. D., Cunningham, J. D., and Salisch, H. A., 1971, South Lake Maracaibo log analysis: Society of Professional Well Log Analysts Annual Logging Symposium, 12th, Dallas, Tex., 1971, Transactions, p. Q1-Q15.

Brown, H. D., and Salisch, H. A., 1967, Logging programs in northeastern South America: Society of Professional Well Log Analysts Annual Logging Symposium, 8th, Denver, Colo., 1967, Transactions, p. H1-H27.

Brown, J. S., 1966, Formation evaluation in heavy oil sands: Society of Professional Well Log Analysts Annual Logging Symposium, 7th, Tulsa, Okla., 1966, Transactions, p. B1B14.

Caldwell, J. W., and Strabala, J. M., 1970, Application of modern well logging methods to salt solution cavities: Northern Ohio Geological Society Symposium on Salt, 3d, Cleveland, Ohio, 1969, Proceedings, v. 2, p. 341-352.

Caldwell, R. L., 1967, Well logging in the USSR: Society of Professional Well Log Analysts Annual Logging Symposium, 8th, Denver, Colo., 1967, Transactions, p. C1C30.

1969, Isotope technology development-Nuclear logging methods: Isotopes and Radiation Technology, v. 6, no. 3, p. 257-273.

Caldwell, R. L., Desai, K. P., and Mills, W. R., Jr., 1974, Geophysical well logging using nuclear techniques: International Atomic Energy Agency Panel on Nuclear Techniques in Geochemistry and Geophysics, Vienna, Austria, 1974, Proceedings, p. 3-19.

Campbell, R. M., 1967, Introduction to a review of $\log$ interpretation methods used in the Niger Delta: Society of Professional Well Log Analysts Annual Looging Symposium, 8th, Denver, Colo., 1967, Transactions, p. Y1-Y4.

Carroll, R. D., and Cunningham, M. J., 1978, Geophysical investigations in connection with the Dining Car Event, U12e.18 Tunnel, Rainier Mesa, Nevada Test Site: U.S. Geological Survey, issued by the U.S. Department of Commerce, National Technical Information Service, Report USGS-474-246, 28 p. 
Carroll, R. D., and Muller, D. C., 1973, Techniques for the quantitative determination of alluvial physical properties from geophysical logs, Southern Yucca Flat, Nevada Test Site: U.S. Geological Survey, issued by the U.S. Department of Commerce, National Technical Information Service, Report USGS-474-175, 113 p.

Carter, V. B., 1966, Supplementing sample logs: Ground Water, v. 4 , no. 3, p. 49-51.

Clayton, C. G., 1967, A survey of the application of radiation techniques in oil and mineral boreholes: Wantage Berkshire, England, Isotope Research Division, Report AERE-R5368, 59 p.

Commission on Standardization of Laboratory and Field Tests, 1981, Suggested methods for geophysical logging of boreholes: International Journal of Rock Mechanics, Mineral Sciences, and Geomechanics Abstracts, v. 18, no. 1, p. $67-84$.

Connell, J. G., and Shapiro, R. M., 1974, Logging operations in sour gas wells: Society of Petroleum Engineers of the American Institute of Mining, Metallurgical, and Petroleum Engineers Paper SPE 5197, 9 p.

Connor, D. C., and Kelland, D. G., 1974, Piper Field, UK North Sea-Evaluation of Jurassic reservoir sands by interpretive $\log$ analysis correlated with core data: Society of Professional Well Log Analysts European Symposium, 3d, London, England, 1974, Transactions, p. A1-A14.

Cook, J. C., and Clements, J. R., 1970, NQR borehole logging for evaporate minerals: Northern Ohio Geological Society, Symposium on Salt, 3d, Cleveland, Ohio, 1969, Proceedings, v. 2, p. 353-356.

Coolidge, J. E., and others, 1962, NML resolves difficult logging logging problems: Society of Professional Well Log Analysts Annual Logging Symposium, 3d, Houston, Tex., 1962, Transactions, $24 \mathrm{p}$.

Crosby, J. W., III, 1973, Geophysical logging capabilities and procedures of boreholes in nuclear power plant site investigations: Pullman, Washington, Washington State University Report no. 73/15-84, 23 p.

Czubek, J. A., 1970, Recent Russian and European developments in nuclear geophysics applied to mineral exploration and mining, in Scott, J. H., ed., Nuclear methods of field exploration for natural resources, American Chemical Society Spring Meeting, Houston, Tex., 1970, Transactions, Paper no. 15, 73 p.; Log Analyst, v. 12, no. 6, p. $20-34$.

Dakhnov, V. N., 1959, Geophysical well logging: Quarterly of the Colorado School of Mines, v. 57, no. 2, 445 p.

1964, Geophysical well logging: Neftyanoye Khozyaystvo (Petroleum Economy), v. 42, no. 9-10, p. 121-123.

Daniels, J. J., and Scott, J. H., 1980, Borehole geophysical measurements for hole UE25-3, Nevada Test Site, Nuclear Waste Isolation Program: U.S. Geological Survey Open-File Report 80-126, 32 p.

Daniels, J. J., Scott, J. H., and Hite, R. J., 1979, Analysis of borehole geophysical data in an evaporite sequence at Salt Valley, Utah: Society of Professional Well Log Analysts Annual Logging Symposium, 20th, Tulsa, Okla., 1979, Transactions, p. M1-M19.
Daniels, J. J., Scott, J. H., and Olhoeft, G. R.,, 1981, Interpreting Precambrian metamorphic geology from geophysical well logs: Society of Professional Well Log Analysts Annual Logging Symposium, 22d, Mexico City, Mexico, 1981, Transactions, p. T1-T17.

Desbrandes, Robert, 1973, What's new in downhole operating technology: World Oil, v. 176, no. 7, p. 74-75, 78.

Dietl, H., and others, 1966, Observations on the utilization of the scattering of gamma rays and neutrons to investigate underground aquifers, in Radioisotope instruments in industry and geophysics: International Atomic Energy Agency Symposium, Warsaw, Poland, 1965, Proceedings, v. 2 , p. $435-447$.

Dodd, P. H., 1966, Quantitative logging and interpretation systems to evaluate uranium deposits: Society of Professional Well Log Analysts Annual Logging Symposium, 7th, Tulsa, Okla., 1966, Transactions, p. P1-P21.

Doll, H. G., 1955, Filtrate invasion in highly permeable sands: Petroleum Engineer, v. 27, no. 1, p. B53-B66.

Duda, J. R., and Pierce, C. I., 1968, A comparison between $\log$ and core analyses from Appalachian area oil wells: Producers Monthly, v. 32, no. 5, p. 2-3, 22-23.

Dyck, A. V., ed., 1975, Borehole geophysics applied to metallic mineral prospecting-A review: Geological Survey of Canada Paper 75-31, 66 p.

Dyck, J. H., 1973, Some applications of borehole logging to Quaternary research-A study in southern Saskatchewan: Geoexploration, v. 11, no. 4, p. 233-247.

Dyck, J. H., Keys, W. S., and Meneley, W. A., 1972, Application of geophysical logging to groundwater studies in southern Saskatchewan: Canadian Journal of Earth Sciences, v. 9, no. 1, p. 78-94.

Edmundson, H. N., and Raymer, L. L., 1979, Radioactive logging parameters of common minerals: Society of Professional Well Log Analysts Annual Logging Symposium, 20th, Tulsa, Okla., 1979, Transactions, p. 01-020.

Edwards, J. M., Ottinger, N. H., and Haskell, R. E., 1967, Nuclear log evaluation of potash deposits: Society of Professional Well Log Analysts Annual Logging Symposium, 8th, Denver, Colo., 1967, Transactions, p. L1-L12.

Edwards, L. M., and Shane, L. E., 1965, Some human-electrical factors of a quality logging service: Society of Professional Well Log Analysts Annual Logging Symposium, 6th, Dallas, Tex., 1965, Transactions, p. E1-E13.

Emerson, D. W., and Haines, B. M., 1974, The interpretation of geophysical well logs in water bores in unconsolidated sediments: Bulletin of the Australian Society of Exploration Geophysicists, v. 5, no. 3, p. 89-118.

Emerson, D. W., and Webster, S. S., 1970, Interpretation of geophysical logs in bores in unconsolidated sediments, Phase 1: Australian Water Resources Council Research Project 68/7, 222 p.

Evans, H. B., 1970, Status and trends in logging: Geophysies, v. 35 , no. 1 , p. 93-112.

Evans, H. B., and others, 1966, Logging observation wells in an in-situ combustion test: Society of Professional Well Log Analysts Annual Logging Symposium, 7th, Tulsa, Okla., 1966, Transactions, p. DD1-DD37. 
Ferronsky, V. I., and others, 1969, Radioisotope investigative methods in engineering geology and hydrogeology: U.S. Atomic Energy Commission, issued by the U.S. Department of Commerce, National Technical Information Service, Report AEC-tr-7230, $254 \mathrm{p}$.

Fertl, W. H., 1977, Use caution with movable oil plot: Oil and Gas Journal, v. 75, no. 2, p. 65-69.

Fertl, W. H., and Timko, D. J., 1970, Distinction of oil and gas in clean and shaly sands as derived from well logs: Society of Professional Well Log Analysts Annual Logging Symposium, 11th, Los Angeles, Calif., 1970, Transactions, p. I1-I20.

Fetzner, R. W., Henson, W. L., and Feigl, F. J., 1966, Athabasca oil sand evaluation using core and log analysis and geological data processing methods: Society of Professional Well Log Analysts Annual Logging Symposium, 7th, Tulsa, Okla., 1966, Transactions, p. A1-A12.

Garb, F. A., 1978, Clean sand $\log$ analysis and shaly formation sonic-density log analysis,pt. 3 of Property evaluation with hand held computers: Petroleum Engineer International, v. 50 , no. 3 , p. $50,62-80$.

Glanville, C. R., 1970, Log interpretation of thinly-bedded, oilproductive sands with unusually low resistivities: Society of Professional Well Log Analysts Annual Logging Symposium, 11th, Los Angeles, Calif., 1970, Transactions, p. M1-M27.

Gross, Freeman, 1969, Applied and engineering aspects of composite production logging: Society of Petroleum Engineers of the American Institute of Mining, Metallurgical, and Petroleum Engineers Paper SPE 2650, 10 p.

Guyod, Hubert, 1966, Interpretation of electric and gamma ray logs in water wells: Log Analyst, v. 6, no. 5, p. $29-44$.

Hammack, G. W., and Fertl, W. H., 1974, How well logs can be misinterpreted: World Oil, v. 179, no. 7, p. 69-73.

1974, Anomalies observed on well logs: Log Analyst, v. 15 , no. 5 , p. $3-15$.

Hartley, K. B., 1979, Evaluation of wireline down log information and effects of increased log speeds on data quality: Society of Petroleum Engineers of the American Institute of Mining, Metallurgical, and Petroleum Engineers Paper SPE 8363, $10 \mathrm{p}$.

Hassen, B. R., 1980, New technique estimates drilling filtrate invasion: Society of Petroleum Engineers of the American Institute of Mining, Metallurgical, and Petroleum Engineers Paper SPE 8791, 8 p.

Hawkins, W. K., and Gearhart, Marvin, 1968, Use of logging in uranium prospecting: Society of Professional Well Log Analysts Annual Logging Symposium, 9th, New Orleans, La., 1968, Transactions, p. T1-T13.

Hearst, J. R., and Carlson, R. C., 1970, Well-logging research for geonuclear technology: Nuclear Applications and Technology, v. 8, p. 276-282.

Heflin, H. D., Neil, B. E., and DeVries, M. R., 1976, Log evaluation in the California Miocene formations: Society of Petroleum Engineers of the American Institute of Mining, Metallurgical, and Petroleum Engineers Paper SPE $6160,18 \mathrm{p}$.

Heise, Horst, 1965, Well logging opens new methods for exploration: Oilweek, v. 16 , no. 25 , p. 20-23.
Helander, D. P., Graves, R. W., and Martinez, S. J., 1967, Sources of "lost" information for log analysts: Society of Professional Well Log Analysts Annual Logging Symposium, 8th, Denver, Colo., 1967, Transactions, p. G1G19.

Hilchie, D. W., 1977, Nuclear well logging for petroleum: Developments in Economic Geology, no. 7, p. 201-213.

Hossin, A., and others, 1970, Application to the Hassi-Messoud Cambrian reservoir of a new quantitative interpretation method for shaly sands: Society of Professional Well Log Analysts Annual Logging Symposium, 11th, Los Angeles, Calif., 1970, Transactions, p. H1-H28.

International Atomic Energy Agency, 1971, Nuclear well logging in hydrology: Vienna, Austria, Technical Report Series no. $126,88 \mathrm{p}$.

1974, Nuclear techniques in geochemistry and geophysics: Panel on Nuclear Techniques in Geochemistry and Geophysics, Vienna, Austria, 1974, Proceedings, 271 p.

Jack, R. S., 1973, The role of the CNL-FDC combination in distinguishing oil, water and gas zones, Texas Gulf Coast: Society of Petroleum Engineers of the American Institute of Mining, Metallurgical, and Petroleum Engineers Paper SPE 4509, $6 \mathrm{p}$.

Jeffries, F. S., 1964, Wireline logs_The infant oil finding technique: Log Analyst, v. 5, no. 1, p. 41-52.

1968, Reservoir volume calculations with a well data system: Log Analyst, v. 9, no. 3, p. 3-11.

Jenkins, J. C., 1969, Practical applications of well logging to mine design: Society of Mining Engineer of the American Institute of Mining, Metallurgical, and Petroleum Engineers Paper 69-F-73, 29 p.

Johnson, A. I., 1963, Geophysical logging of boreholes for hydrologic studies: U.S. Geological Survey Open-File report, $11 \mathrm{p}$.

Johnson, H. M., 1960, Duties of a logging co-ordinator in an operating company: Geophysics, v. 25, no. 4, p. 734-747.

1962, A history of well logging: Geophysies, v. 27, no. 4 , p. $507-527$.

Jones, Bob, 1967, Case histories of subsurface log data exploration patterns in eastern Powder River basin, Wyoming: Society of Professional Well Log Analysts Annual Logging Symposium, 8th, Denver, Colo., 1967, Transactions, p. E1-E16.

Jones, P. H., and Skibitzke, H. E., 1956, Subsurface geophysical methods in ground-water hydrology, in v. 3 of Landsberg, H. E., ed., Advances in Geophysies: New York, Academic Press, p. 2411-300.

Keller, G. V., 1966, Geophysical well logging in the Soviet Union-A review: Society of Professional Well Log Analysts Annual Logging Symposium, 7th, Tulsa, Okla., 1966, Transactions, p. D1-D40.

Kelley, D. R., 1969, A summary of major geophysical logging methods: Pennsylvania Geological Survey Bulletin M61, 82 p.

Keys, W. S., 1967, Aquifer evaluation with radioisotope well logs: American Water Resources Association National Symposium on Ground-Water Hydrology, San Francisco, Calif., 1967, Proceedings, p. 319_328. 
Keys, W. S., and MacCary, L. M., 1973, Location and characteristics of the interface between brine and fresh water from geophysical logs of boreholes in the upper Brazos River basin, Texas: U.S. Geological Survey Professional Paper 809-B, p. B1-B23.

King, E. E., and Fertl, W. H., 1978, Improved analysis methods solve new logging problems: Oil and Gas Journal, v. 76, no 20 , p. $59-62$.

Kirkpatrick, J. R., 1979, Results of downhole geophysical logging hole 396B, DSDP Leg 46, in Initial report of the Deep Sea Drilling Project: Washington, D.C., U.S. Government Printing Office, v. 46, p. 401-417.

Labo, J., 1978, A practical introduction to borehole geophysies: Society of Exploration Geophysicists Annual Meeting, 48th, San Francisco, Calif., 1978, Proceedings, p. 1-44.

Lamont, Norman, 1966, Spectrum of formation: Petroleum Engineer, v. 38 , no. 4 , p. $60-63$, 100-104.

1966, Spectrum of formation, pt. 2-Evaluation and how to use it: Petroleum Engineer, v. 38, no. 6, p. 90-104.

1969, Are all those logs really necessary?: Log Analyst, v. 10 , no. 3 , p. $44-47$.

Lavers, B. S., Smits, L. J. M., and van Baaren, C., 1974, Some fundamental problems of formation evaluation in the North Sea: Society of Professional Well Log Analysts European Symposium, 3d, London, England, 1974, Transactions, p. G1-G12.

Lawson B. L., Hoyer, W. A., and Pickett, G. R., eds., 1978, Gamma ray, neutron, and density logging (Reprint Volume): Houston, Tex., Society of Professional Well Log Analysts, 260 p.

Lebourg, M., Campbell, A. T., and Witterholt, E. J., 1967, Detection of deep formation "damage": Society of Professional Well Log Analysts Annual Logging Symposium, 8th, Denver, Colo., 1967, Transactions, p. Q1-Q22.

Lebreton, F., and others, 1963, Formation evaluation with nuclear and acoustic logs: Society of Professional Well Log Analysts Annual Logging Symposium, 4th, Oklahoma City, Okla., 1963, Transactions, p. IX1-IX18.

Lehr, J. H., 1971, An introduction to ground water geophysics, part 1: Water Well Journal, v. 25, no. 7, p. 43-60.

1971, Applied use of geophysics, part 2: Water Well Journal, v. 25, no. 8, p. 35-50.

Lindseth, R. O., 1966, Application of signal theory to well log interpretation: Society of Professional Well Log Analysts Annual Logging Symposium, 7th, Tulsa, Okla., 1966, Transactions, p. S1-S21.

Lukes, Jiri, 1973, Filtration properties of rocks determined from digital well-logging measurements: Acta Universitatis Carolinae-Geologica no. 4, p. 289-304.

Mardock, E. S., 1960, Radioactivity logging and its future potential: Geophysics, v. 25, no. 4, p. 883-890.

Millican, M. L., Raymer, L. L., and Alger, R. P., 1964, Wellsite recording of movable oil plot: Society of Professional Well Log Analysts Annual Logging Symposium, 5th, Midland, Tex., 1964, Transactions, p.F1-F11.

Misk, Andre, and Poupon, Andre, 1966, Logging problems in the North Sea: Society of Professional Well Log Analysts Annual Logging Symposium, 7th, Tulsa, Okla., 1966, Transactions, p. G1-G18.

Moore, E. J., and Desai, K. P., 1970, A multi-pad acoustic-resistivity dipmeter tool: $\log$ Analyst, v. 11, no. 2, p. 45-46.
Moran, J. H., and Gianzero, S. C., 1982, Electrical anistrophy-Itseffect on well logs, in Fitch, A. A., ed., Developments in geophysical exploration methods-3: London, England, Elsevier Applied Science Publishers, p. 195-238.

Nelner, S. H., 1966, Logisties and problems of Arctic and subArctic logging: Society of Professional Well Log Analysts Annual Logging Symposium, 7th, Tulsa, Okla., 1966, Transactions, p. Y1-Y7.

Nelson, P. H., and others, 1979, Preliminary report on geophysical and mechanical borehole measurements at Stripa: U.S. Department of Commerce, National Technical Information Service, Report LBL-8280, 165 p.

Oliver, D., 1977, The use of wireline logging to investigate problems in water supply boreholes: Society of Professional Well Log Analysts European Symposium, 5th, Paris, France, 1977, Transactions, p. 1-14.

Paul, R. H., 1967, Log interpretation in complex gas bearing reefs, northeast British Columbia: Society of Professional Well Log Analysts Annual Logging Symposium, 8th, Denver, Colo., 1967, Transactions, p. J1-J13.

Pichugin, N. I., and Aripzhanov, A. A., 1965, Geophysical investigations during hydrogeological experimentations in boreholes: Uzbek Geological Journal, no. 2, p. 18-23.

Pickett, G. R., 1969, Principles for application of borehole measurements in petroleum engineering: Log Analyst, v. 10, no. 3, p. 22-23.

1970, Applications for borehole geophysics in geophysical exploration: Geophysics, v. 35, no. 1, p. 81-92.

1973, Pattern recognition as a means of formation evaluation: Log Analyst, v. 14, no. 4, p. 3-11.

Pirson, S. J., 1965, The education of a well $\mathrm{log}$ analyst: Society of Professional Well Log Analysts Annual Logging Symposium, 6th, Dallas, Tex., 1965, Transactions, p. D1-D11.

1966, Oil finding by systematic well $\log$ analysis: Log Analyst, v. 6, no. 5, p. 4-17.

1970 , environmental logging and mapping in the search for minerals: Log Analyst, v. 11, no. 2, p. 23-44.

Pirson, S. J., Trunz, J. P., Jr., and Gomez-N., P., 1967, Fracture intensity mapping from well logs and from structure maps: Society of Professional Well Log Analysts Annual Logging Symposium, 8th, Denver, Colo., 1967, Transactions, p. B1-B23.

Poupon, Andre, and Gaymard, R., 1970, The evaluation of clay content from logs: Society of Professional Well Log Analysts Annual Logging Symposium, 11th, Los Angeles, Calif., 1970, Transactions, p. G1-G21.

Poupon, Andre, Strecker, I., and Gartner, J., 1967, A review of log interpretation methods used in the Niger Delta: Society of Professional Well Log Analysts Annual Logging Symposium, 8th, Denver, Colo., 1967, Transactions, p. Z1-Z53.

Ransom, R. C., ed., 1975, Glossary of terms and expressions used in well logging: Houston, Tex., Society of Professional Well Log Analysts, 74 p.

Rhodehamel, E. C., 1975, Geophysical logs from a geologic test hole near Charleston, South Carolina: U.S. Geological Survey Open-File Report 75-247, 4 p.

Robertson, R. A., 1966, Formation evaluation in foreign operations: Society of Professional Well Log Analysts Annual Logging Symposium, 7th, Tulsa, Okla., 1966, Transactions, p. Z1-Z12. 
Robinson, W. S., 1974, Field results from the noise logging technique: Society of Petroleum Engineers of the American Institute of Mining, Metallurgical, and Petroleum Engineers Paper SPE 5088, 8 p.

Rodermund, C. G., Alger, R. P., and Tittman, Jay, 1961, Logging empty holes: Oil and Gas Journal, v. 59, no. 24, p. 119-124.

Rosen, R. L., 1979, Well log response in unconsolidated sands and determination of pore water salinity: Golden, Colorado School of Mines, M.S. Thesis T-2216, $143 \mathrm{p}$.

Salisch, H. A., and Brown, H. D., 1966, Log interpretation in Bolivia: Society of Professional Well Log Analysts Annual Logging Symposium, 7th, Tulsa, Okla., 1966, Transactions, p. E1-E20.

Schlumberger, Conrad, Schlumberger, Marcel, and Leonardson, E. G., 1932, Electrical coring-A method of determining bottom-hole data by electrical measurements: American Institute of Mining, Metallurgical, and Petroleum Engineers Technical Publication 462, p. 3-38.

Schmalz, B. L., and Keys, W. S., 1962, Retention and migration of radioactive isotopes in the lithosphere at the $\mathrm{Na}$ tional Reactor Testing Station, Idaho: U.S. Atomic Energy Commission, issued by the U.S. Department of Commerce, National Technical Information Service, Report IDO-12026, $25 \mathrm{p}$.

Scott, J. H., and Sena, Joe, 1973, Prediction of geologic and hydrologic conditions ahead of rapid excavation operations by inhole geophysical techniques: U.S. Bureau of Mines, issued by the U.S. Department of Commerce, National Technical Information Service, Report AO-771689/GA, 33 p.

Scott, J. H., and Tibbetts, B. L., 1974, Well-logging techniques for mineral deposit evaluation-A review: U.S. Bureau of Mines Report IC8627, $45 \mathrm{p}$.

Segesman, F. F., 1980, Well-logging method: Geophysics, v. 45 , no. 11 , p. $1667-1684$.

Shamey, L. J., and Adams, W. M., 1973, Three-dimensional zone model log interpretation: Honolulu, University of Hawaii, Water Resources Research Center Technical Report 69, $20 \mathrm{p}$.

Sheriff, R. E., 1970, Glossary of terms used in well logging: Geophysics, v. 35, no. 6, p. 1116-1139.

Sorber, H. W., 1966, Some logging and perforating procedures in NW-Germany: Society of Professional Well Log Analysts Annual Logging Symposium, 7th, Tulsa, Okla., 1966, Transactions, p. F1-F19.

Stein, Nathan, 1975, Mechanical properties of friable sands from conventional log data: Society of Petroleum Engineers of the American Institute of Mining, Metallurgical, and Petroleum Engineers Paper SPE 5500, 12 p.

Tate, T. K., Robertson, A. S., and Gray, D. A., 1970, The hydrogeological investigation of fissure-flow by borehole logging techniques: Quarterly Journal of Engineering Geology, v. 2, no. 3, p. 195-215.

Taylor, K. 0., 1975, Use of automated logging units for predicting abnormally pressured formations and well correlation: Southwestern Petroleum Short Course Association Annual Meeting, 22d, Lubbock, Tex., 1975, Proceedings, p. 1-8.
Threadgold, Philip, 1967, Well logging in Middle Eastern and similar large reservoirs: Society of Professional Well Log Analysts Annual Logging Symposium, 8th, Denver, Colo., 1967, Transactions, p. F1-F20.

1971, Some problems and uncertainties in log interpretation: Society of Professional Well Log Analysts Annual Logging Symposium, 12th, Dallas, Tex., 1971, Transactions, p. W1-W19.

Timur, Aytekin, 198\%, Advances in well logging: Journal of Petroleum Technology, v. 34, no. 6, p. 1181-1185.

Tixier, M. P., 1962, Modern log analysis: Journal of Petroleum Technology, v. 14, no. 12, p. 1327-1336.

Tixier, M. P., and Alger, R. P., 1967, Log evaluation of nonmetallic mineral deposits: Society of Professional Well Log Analysts Annual Logging Symposium, 8th, Denver, Colo., 1967, Transactions, p. R1-R22.

Tixier, M. P., Alger, R. P., and Tanguy, D. R., 1960, New developments in induction and sonic logging: Journal of Petroleum Technology, v. 12, no. 5, p. 79-87.

Towle, Guy, 1965, The log analyst with a service company: Society of Professional Well Log Analysts Annual Logging Symposium, 6th, Dallas, Tex., 1965, Transactions, p. J1J5.

Veneziani, I. I., and others, 1972, The redox log: Society of Professional Well Log Analysts Annual Well Logging Symposium, 13th, Tulsa, Okla., 1972, Transactions, p. D1D19.

Walter, F., ed., 1976, Geophysical well logging for geohydrological purposes in unconsolidated formations: Delft, Netherlands, Netherlands Organization for Applied Scientific Research, Groundwater Survey TNO, $67 \mathrm{p}$.

Wyllie, M. R. J., 1960, Log interpretation in sandstone reservoirs: Geophysics, v. 25, no. 4 , p. 748-778.

Zablocki, C. J., 1966, Some applications of geophysical logging methods in mineral exploration drill holes: Society of Professional Well Log Analysts Annual Logging Symposium, 7th, Tulsa, Okla., 1966, Transactions, p. U1-U13.

Zanier, A. M., and Pert, D. M., 1971, The salinity $\log -\mathbf{A}$ tool to determine reservoir producing properties: Society of Professional Well Log Analysts Annual Logging Symposium, 12th, Dallas, Tex., 1971, p. K1-K11.

\section{BOREHOLE GEOPHYSICS, LOCGING TEXTS}

Barsukov, O. A., and others, 1965, Radioactive investigations of oil and gas wells: New York, MacMillan, 299 p.

Davis, J. C., 1973, Statistics and data analysis in geology: New York, John Wiley, 550 p.

Desbrandes, Robert, 1968, Theorie et interpretation des diagraphies (French): Paris, France, Editions Technip, 545 p.

Guyod, Hubert, and Shane, L. E., 1969, Geophysical well logging-Introduction to geophysical well logging; acoustical logging: Houston, Texas, Hubert Guyod, v. 1, 256 p.

Hilchie, D. W., 1978, Applied openhole log interpretation: Golden, Colo., D. W. Hilchie, Inc., 309 p.

1979, Old electrical log interpretation: Golden, Colo., D. W. Hilchie, Inc., $163 \mathrm{p}$.

Keller, G. V., and Frischknecht, F. C., 1970, Electrical methods in geophysical prospecting: New York, Pergamon, 519 p. 
Lynch, E. J., 1962, Formation evaluation: New York, Harper and Row, $428 \mathrm{p}$.

Pirson, S. J., 1963, Handbook of well $\log$ analysis for oil and gas formation evaluation: Englewood Cliffs, N. J., Prentice-Hall, $325 \mathrm{p}$.

1970, Geologic well log analysis: Houston, Tex., Gulf Publishing Company, 370 p.

Wyllie, M. R. J., 1963, The fundamentals of well log interpretation (3d ed., revised): New York, Academic Press, 238 p.

\section{CALIBRATION}

American Petroleum Institute, 1963, Recommended practice for standard calibration and form for nuclear logs (2d ed.): Dallas, Tex., Division of Production, Publication API RP33, 12 p.

Cochrane, J. E., 1966, Principles of log calibration and their application to log accuracy: Journal of Petroleum Technology, v. 18 , no. 7 , p. 817-826.

Crew, M. E., 1979, MULTIPIT, a method for calibration of logging systems: Society of Professional Well Log Analysts Annual Logging Symposium, 20th, Tulsa, Okla., 1979, Transactions, p. II1-II15.

Crew, M. E., and Berkoff, E. W., 1970, TWOPIT, a different approach to calibration of gamma-ray logging equipment: Log Analyst, v. 11, no. 6, p. 26-32.

Knox, C. C., 1975, Quality control of well logs: Log Analyst, v. 16 , no. 3 , p. 14-20.

Lang, W. H., Jr. 1980, Porosity log calibrations: Log Analyst, v. 21 , no. 2 , p. 14-19.

Mathews, M. A., 1980, Calibration models for fractured igneous rock environments: Society of Professional Well Log Analysts Annual Logging Symposium, 21st, Lafayette, La., 1980, Transactions, p. L1-L11.

Merkel, R. H., and Snyder, D. D., 1977, Application of calibrated slim hole logging tools to quantitative formation evaluation: Society of Professional Well Log Analysts Annual Logging Symposium, 18th, Houston, Tex., 1977, Transactions, p. X1-X21.

Scott, J. H., 1980, Pitfalls in determining the dead time of nuclear well-logging probes: Society of Professional Well Log Analysts Annual Logging Symposium, 21st, Lafayette, La., 1980, Transactions, p. H1-H11.

Sherman, Harold, and Locke, Stanley, 1975, Depth of investigation of neutron and density sondes for 35-percent-porosity sand: Canadian Well Logging Society Formation Evaluation Symposium, 5th, Calgary, Alberta, 1975, Transactions, p. B1-B10.

Snodgrass, J. J., 1976, Calibration models for geophysical borehole logging: U.S. Bureau of Mines Report of Investigations RI8148, $21 \mathrm{p}$.

Stephen, W. F., 1982, Participatory $\log$ quality control: Society of Professional Well Log Analysts Annual Logging Symposium, 23d, Corpus Christi, Tex., 1982, Transactions, p. D1-D11.

Waller, W. C., Cram, M. E., and Hall, J. E., 1975, Mechanics of log calibration: Canadian Well Logging Society Formation Evaluation Symposium, 5th, Calgary, Alberta, 1975, Transactions, p. BB1-BB8.
Wells, L. E., Sanyal, S. K., and Mathews, M. A., 1979, Matrix and response characteristics for sonic, density, and neutron: Society of Professional Well Log Analysts Annual Logging Symposium, 20th, Tulsa, Okla., 1979, Transactions, p. Z1-Z25.

\section{CALIPER}

Dawson-Grove, G. E., 1969, Sonar caliper applications in western Canada: Society of Professional Well Log Analysts Annual Logging Symposium, 10th, Houston, Tex., 1969, Transactions, p. E1-E14.

Hilchie, D. W., 1968, Caliper logging-Theory and practice: Log Analyst, v. 9, no. 1, p. 3-12.

Thomas, H. E., and Smith, J. W., 1970, Caliper location of leached zones in Colorado oil shale: Log Analyst, v. 11, no. 4, p. 12-16.

\section{CARBONATES}

Beck, J. A., Schultz, A. L., and Fitzgerald, D. D., 1977, Reservoir evaluation of fractured Cretaceous carbonates in south Texas: Society of Professional Well Log Analysts Annual Logging Symposium, 18th, Houston, Tex., 1977, Transactions, p. M1-M25.

Camargo, Orlando, and Fons, Lloyd, 1965, Logging considerations for Mississippi lime evaluation in Oklahoma: Log Analyst, v. 6, no. 3, p. 55-61.

Chombart, L. G., 1960, Well logs in carbonate reservoirs: Geophysies, v. 25 , no. 4 , p. $779-853$.

MacCary, L. M., 1971, Resistivity and neutron logging in Silurian dolomite of northwest Ohio, in Geological Survey Research 1971: U.S. Geological Survey Professional Paper 750-D, p. D190-D197.

1978, Interpretation of well logs in a carbonate aquifer: U.S. Geological Survey Water-Resources Investigations $78-8,35$ p.

Pickett, G. R., and Artus, D. S., 1970, Prediction from logs of recoverable hydrocarbon volume, Ordovician carbonates-Williston basin: Geophysics, v. 35, no. 1, p. 113-123.

Traugott, M. O., 1970, Log evaluation of a heterogeneous carbonate reservoir-Cato San Andres Field: Society of Professional Well Log Analysts Annual Logging Symposium, 11th, Los Angeles, Calif., 1970, Transactions, p. E1-E8.

White, E. J., and Marchant, L. C., 1970, Reservoir rock characteristics of the Madison Limestone in the Williston basin: Log Analyst, v. 11, no. 5, p. 17-25.

\section{CASING AND CEMENT BOND LOGS}

Ahmed, A. E., 1977, A neutron logging method for locating the top of cement behind borehole casing: Journal of Petroleum Technology, v. 29, no. 9, p. 1089-1090.

Baltosser, R. W., and Honea, Cecil, 1976, The improved Birdwell casing finder: Society of Petroleum Engineers of the American Institute of Mining, Metallurgical, and Petroleum Engineers Paper SPE 6161, 12 p.

Cuthbert, J. F., and Johnson, W. M., Jr., 1974, New casing inspection log: Society of Petroleum Engineers of the American Institute of Mining, Metallurgical, and Petroleum Engineers Paper SPE 5090, 12 p. 
Edwards, J. M., and Stroud, S. G., 1963, A report on field results of the electromagnetic casing inspection log: Society of Petroleum Engineers of the American Institute of Mining, Metallurgical, and Petroleum Engineers Paper SPE 664, 8 p.

1965, New electronic casing caliper log introduced for corrosion detection: Society of Petroleum Engineers of the American Institute of Mining, Metallurgical, and Petroleum Engineers Paper SPE 1327, 7 p.

Fertl, W. H., Pilkington, P. E., and Odd, R. A., 1974, Cement bond logging in the North Sea area: Society of Professional Well Log Analysts European Symposium, 3d, London, England, 1974, Transactions, p. 01-020.

Fertl, W. H., Pilkington, P. E., and Scott, J. B., 1973, A look at cement bond logs: Society of Petroleum Engineers of the American Institute of Mining, Metallurgical, and Petroleum Engineers Paper SPE 4512, 12 p.

Kendall, H. A., 1965, Application of SP curves to corrosion detection: Journal of Petroleum Technology, v. 17, no. 9, p. 1029-1032.

Lindsey, R. A., 1974, Casing potential logging related to VERTILOG corrosion logging: Chicago, Ill., National Association of Corrison Engineers, International Corrosion Forum, Paper 66, $6 \mathrm{p}$.

Muir, D. M., and Rollman, E. E., 1970, New look at bond logging: Petroleum Engineer, v. 42, no. 2, p. 72, 78.

Pickett, G. R., 1966, Prediction of interzone fluid communication behind casing by use of the cement bond log: Society of Professional Well Log Analysts Annual Logging Symposium, 7th, Tulsa, Okla., 1966, Transactions, p. J1-J27.

Ruedrich, R. A., Perkins, T. K., and O'Brian, D. E., 1974, Precise joint length determination using a multiple casing collar locator tool: Society of Petroleum Engineers of the American Institute of Mining, Metallurgical, and Petroleum Engineers Paper SPE 5087, 15 p.

Stroud, S. G., and Fuller, C. A., 1961, New electromagnetic inspection device permits improved casing corrosion evaluation: Society of Petroleum Engineers Annual Fall Meeting, 36th, Dallas, Tex., 1961, Proceedings, p. 1-4.

Upp, J. E., 1966, The use of the cement bond log in well rehabilitation: Society of Professional Well Log Analysts Annual Logging Symposium, 7th, Tulsa, Okla., 1966, Transactions, p. X1-X11.

Williams, G. B., 1970, Sonic principles applied to formation fracture location and cement bond logging: Canadian Well Logging Society Journal, v. 3, no. 1, p. 7-15.

Winn, R. H., Anderson, T. O., and Carter, L. G., 1961, A progress report on the interpretation of cement bond logs: Society of Petroleum Engineers of the American Institute of Mining, Metallurgical, and Petroleum Engineers Paper SPE 132, 7 p.

1962, A preliminary study of factors influencing cement bond logs: Journal of Petroleum Technology, v. 14, no. 4, p. $369-372$.

\section{COAL}

Bond, L. O., Alger, R. P., and Schmidt, A. W., 1969, Well log applications in coal mining and rock mechanics: Society of Mining Engineers of the American Institute of Mining, Metallurgical, and Petroleum Engineers Paper 69F13, 11 p.
Daniels, J. J., and Scott, J. H., 1980, Computer-assisted interpretation of geophysical well logs in a coal depositional environment, Illinois Basin, Kentucky: U.S. Geological Survey Bulletin 1509, 44 p.

Flores, R. M., Toth, J. C., and Moore, T. A., 1982, Use of geophysical logs in recognizing depositional environments in the Tongue River Member of the Fort Union Formation, Powder River area, Wyoming and Montana: U.S. Geological Survey Open-File Report 82-576, 44 p.

Hoffman, G. L., Jordan, G. R., and Wallis, G. R., 1982, Geophysical borehole logging handbook for coal exploration: Edmonton, Alberta, The Coal Mining Research Centre, $270 \mathrm{p}$.

Kowalski, J. J., and Fertl, W. H., 1977, Application of geophysical well logs: Society of Petroleum Engineers of the American Institute of Mining, Metallurgical, and $\mathrm{Pe}$ troleum Engineers Paper SPE 5503, 16 p.

Miller, W. R., 1976, Water in carbonate rocks of the Madison Group in southeastern Montana-A preliminary evaluation: U.S. Geological Survey Water-Supply Paper 2043, $51 \mathrm{p}$.

Nelms, C. A., 1976, Application of electrical well-logging techniques to identifying coal beds in the Powder River basin, Wyoming: U.S. Geological Survey Open-File Report 76$581,58 \mathrm{p}$.

Peeters, M., and Kempton, N. H., 1977, Wireline logging for coal exploration in Australia: Log Analyst, v. 18, no. 3, p. 24-29.

Samworth, J. R., 1974, The radiation density log applied to the resolution of thin beds in coal measures: Society of Professional Well Log Analysts European Symposium, 3d, London, England, 1974, Transactions, p. R1-R12.

U.S. Geological Survey, and Montana Bureau of Mines and Geology, 1977, Geophysical logs for Powder River and Dawson Counties, Montana, chapter $\mathrm{C}$ of Preliminary report of 1977 coal drilling in eastern Montana and northeastern Wyoming: U.S. Geological Survey Open-File Report 77-721-C, 79 p.

\section{COMPUTER ANALYSIS}

Althaus, Voy, 1970, Computer program for constructing abnormal formation fluid pressure prediction charts: Society of Professional Well Log Analysts Annual Logging Symposium, 11th, Los Angeles, Calif., 1970, Transactions, p. L1-L18.

Anderson, W. B., 1970, Computer processing of well logs: Canadian Well Logging Society Journal, v. 3, no. 1, p. $85-88$.

Atwood, J. W., Killpack, T. J., and Glenn, W. E., 1980, Computer system for digitizing, analyzing, and plotting log data (A user's guide to WELLOG, Rev. 1): U.S. Department of Energy, issued by the U.S. Department of Commerce, National Technical Information Service, Report DOE/ID/12079-1, 70 p.

Branisa, Frank, 1973, Filtering of well log curves: Geophysics, v. 39 , no. 4 , p. $545-549$.

Breitenbach, E. A., 1965, The universal log interpretation computer program: Society of Professional Well Log Analysts Annual Logging Symposium, 6th, Dallas, Tex., 1965, Transactions, p. J1-J20. 
Buckner, G. O., 1964, Field digital recording of well log data: Society of Professional Well Log Analysts Annual Logging Symposium, 5th, Midland, Tex., 1964, Transactions, p. H1-H7.

1967, Film strip scanner for computer input: Society of Professional Well Log Analysts Annual Logging Symposium, 8th Denver, Colo., 1967, Transactions, p. V1V10.

1972, Minicomputer field taping and computing system [abs.]: Society of Professional Well Log Analysts Annual Logging Symposium, 13th, Tulsa, Okla., 1972, Transactions, p. Z1.

Coates, G. R., Schulze, R. P., and Throop, W. H., 1982 , Volan-An advanced computational log analysis: Society of Professional Well Log Analysts Annual Logging Symposium, 23d, Corpus Christi, Tex., 1982, Transactions, p. A1-A24.

Collins, H. N., and Pilles, D., 1981, Benefits of linear bivariate $\log$ analysis models: Society of Petroleum Engineers of the American Institute of Mining, Metallurgical, and Petroleum Engineers Paper SPE 10105, 12 p.

Connolly, E. T., 1974, Digital log analysis-Recognition and treatment of field recording errors: Society of Professional Well Log Analysts Annual Logging Symposium, 15th, McAllen, Tex., 1974, Transactions, p. S1-S45.

Daniels, J. J., and Scott, J. H., 1980, Computer-assisted interpretation of geophysical well logs in a coal depositional environment, Illinois Basin, Kentucky: U.S. Geological Survey Bulletin 1509, 44 p.

deVergie, P. C., 1968, The computer as a tool in exploration and ore reserves analysis: Grand Junction, Colo., U.S. Atomic Energy Commission, $44 \mathrm{p}$.

Doveton, J. H., and Cable, H. W., 1980, KOALA, Kansas online automated log analysis system ABECEDARIUM and flight manual: Kansas Geological Survey, University of Kansas, 190 p.

Eaton, F. M., and others, 1976, The CYBER Service Unit: Society of Petroleum Engineers of the American Institute of Mining, Metallurgical, and Petroleum Engineers Paper SPE 6158, 10 p.

Evans, H. B., 1965, The universal log interpretation computer program-Nuclear log evaluation: Society of Professional Well Log Analysts Annual Logging Symposium, 6th, Dallas, Tex., 1965, Transactions, p. K1-K35.

Ferm, J. C., and Berger, J. T., 1979, A computer graphics system preparing coal bore hole data for mapping: Computer Graphics, v. 2, no. 8, p. 20-27.

Ferm, J. C., Smith, G. C., and Berger, J. T., 1982, A computer assisted logging and map preparation system utilizing the three-digit code core book: Rocky Mountain Coal Symposium, Denver, Colo., 1982, Proceedings, p. 1-15.

Finklea, E. E., 1965, Current status of the art of machine data processing of logging information: Society of Professional Well Log Analysts Annual Logging Symposium, 6th, Dallas, Tex., 1965, Transactions, p. E1-E17.

Ford, M. E., Bains, A. J., and Tarron, R. D., 1974, Log analysis by linear programming: Society of Professional Well Log Analysts European Symposium, 3d, London, England, 1974, Transactions, p. B1-B20.
Frost, Elton, Jr., and Fertl, W. H., 1980, Interactive digital wellsite formation evaluation-The Prolog system: Society of Petroleum Engineers of the American Institute of Mining, Metallurgical, and Petroleum Engineers Paper SPE $8919,21 \mathrm{p}$.

1980, A computerized well site log analysis system, part 1: Log Analyst, v. 21, no. 6, p. 10-22.

1981, Prolog wellsite analysis, part 2: Log Analyst, v. 22 , no. 1 , p. $14-32$.

Gans, Philip, 1963, Log analysis on a small computer: Society of Professional Well Log Analysts Annual Logging Symposium, 4th, Oklahoma City, Okla., 1963, Transactions, p. I1-I19.

1966, Quantitative well log analysis via computer driven graphic terminals: Society of Professional Well Log Analysts Annual Logging Symposium, 7th, Tulsa, Okla., 1966, Transactions, p. EE1-EE15.

Gill, Dan, 1970, Application of a statistical zonation method to reservoir evaluation and digitized-log analysis: Bulletin of the American Association of Petroleum Geologists, v. 54 , no. 5 , p. $719-729$.

Head, M. P., 1977, Wellsite computer analysis-A program for complex lithologies: Society of Petroleum Engineers of the American Institute of Mining, Metallurgical, and Petroleum Engineers Paper SPE 6824, 7 p.

Head, M. P., and Gearhart, Marvin, 1977, Wellsite formation analysis using the DDL computer: Society of Petroleum Engineers of the American Institute of Mining, Metallurgical, and Petroleum Engineers Paper SPE 6541, 8 p.

Horn, M. K., 1963, A computer method for retrieving water resistivity data: Society of Professional Well Log Analysts Annual Logging Symposium, 4th, Oklahoma City, Okla., 1963, Transactions, p. III1-III18.

Horn, M. K., and Slack, H. A., 1962, COMLOG-A comprehensive computer system for log interpretation: Journal of Petroleum Technology, v. 14, no. 10, p. 1109-1114.

Horvath, S. B., 1973, The accuracy of petrophysical parameters as derived by computer processing: Log Analyst, v. 16 , no. 6 , p. $16-25$.

Jeffries, F. S., 1966, A computer test for errors in acoustictype logs: Log Analyst, v. 7, no. 2, p. 13-16.

1966, Computer correlation of wireline log parameters and core analysis parameters: Log Analyst, v. 7, no. 3, p. 6-14.

1967, Reservoir volume calculations with a well data system: Society of Professional Well Log Analysts Annual Logging Symposium, 8th, Denver, Colo., 1967, Transactions, p. A1-A17.

Jeffries, F. S., and Kemp, E. M., 1963, Computer reconciliation of sonic $\log$ and core analyses in the Boundary Lake field: Society of Professional Well Log Analysts Annual Logging Symposium, 4th, Oklahoma City, Okla., 1963, Transactions, p. IV1-IV18.

Johnson, H. M., 1965, An automated approach to formation evaluation: Society of Professional Well Log Analysts Annual Logging Symposium, 6th, Dallas, Tex., 1965, Transactions, p. $1-3$.

Keener, M. H. L., 1965, Computer coordinated core and log interpretation: Society of Professional Well Log Analysts Annual Logging Symposium, 6th, Dallas, Tex., 1965, Transactions, p. G1-G16. 
Keys, W. S., 1967, Magnetic tape recording of geophysical logs, in U.S. Geological Survey Research 1967: U.S. Geological Survey Professional Paper 575-C, p. C242C246.

Kulinkovich, A. E., Sokhranov, N. N., and Churinova, I. M., 1964, The location of bed boundaries and identification of sandstones on the basis of electric well logging data with the aid of digital computers: Prikladnaya Geofizika, no. 39, p. 107-113, and Glen Ridge, N.J., Associated Technical Services, Inc., 8 p.

Kwon, Byung-Doo, 1977, Spectral analysis of geophysical logs for correlation [University of Indiana, $\mathrm{Ph}$. D dissertation]: University Microfilms International, Publication 78-05604, 256 p.

Kwon, Byung-Doo, Blakely, R. F., and Rudman, A. J., 1978, Power spectral analysis, pt. 2 of Fortran program for correlation of stratigraphic time series: Indiana Geological Survey Occasional Paper 26, 50 p.

Logan, M. H., and others, 1968, Computer determination of true dip and strike for planar structures intersected by an inclined drill hole: Denver, Colo., U.S. Bureau of Reclamation Report 109573, $40 \mathrm{p}$.

Matiisen, A., 1974, Well log compuation and data transmission using time-share computers: Society of Professional Well Log Analysts European Symposium, 3d, London, England, 1974, Transactions, p. F1-F11.

Matuszak, D. R., 1963, Construction of porosity, Rwa, Rw, water saturation, permeability, and travel time versus resistivity plots by the IBM 704 computer: Society of Professional Well Log Analysts Annual Logging Symposium, 4th, Oklahoma City, Okla., 1963, Transactions, p. II1II15.

1966, Stratigraphic trend studies by electronic computer: World Oil, v. 163, no. 2, p. 61-65, 92.

1972, Stratigraphic correlation of subsurface geologic data by computer: Mathematical Geology, v. 5, no. 4, p. 331-343.

Mayer, C., and Sibbit, A., 1980, Global, a new approach to computer-processed log interpretation: Society of Petroleum Engineers of the American Institute of Mining, Metallurgical, and Petroleum Engineers Paper SPE 9431, $14 \mathrm{p}$.

McFadzean, T. B., 1972, Cross-plotting-A neglected technique in log analysis: Canadian Well Logging Society Journal, v. 5, no. 1 , p. 69-99.

McVicar, B. M., 1969, Digital log analysis-Some multivariate and time series approaches: Canadian Society of Exploration Geophysicists Journal, v. 4, no. 1, p. 85-112.

Merkel, R. H., MacCary, L. M., and Chicko, R. S., 1976, Computer techniques applied to formation evaluation: Log Analyst, v. 17, no. 3, p. 3-10.

Miller, C. W., 1980, Wellbore user's manual: Lawrence Berkeley Laboratory, issued by the U.S. Department of Commerce, National Technical Information Service, Report LBL-10910, 48 p.

Moran, J. H., and others, 1962, A progress report on machine interpretation of well logs: Society of Professional Well Log Analysts Annual Logging Symposium, 3d, Houston, Tex., 1962, Transactions, p. 1-27.

Morrison, L. S., and Watson, Robert, 1961, The electronic computer and geophysics: Geophysics, v. 26 , no. 1 , p. 40 44.
Neinast, G. S., and Knox, C. C., 1973, Normalization of well log data: Society of Professional Well Log Analysts Annual Logging Symposium, 14th, Lafayette, La., 1973, Transactions, p. I1-I19.

Offshore Service Technology, 1981, A program for the log analyst's interpretation: v. 14 , no. 10 , p. 14-16.

Olea, R. A., 1981, Log II-A general purpose automated well log evaluation system: Kansas Geological Survey Petrophysical Service Series no. 1, $107 \mathrm{p}$.

Patterson, J. A., deVergie, P. C., and Meehan, R. J., 1964, Application of automatic data processing techniques to uranium ore reserve estimation and analysis, in International Symposium on Applications of Statistics Operations Research and Computers in the Mineral Industry, Golden, Colo., 1964, Proceedings: Golden, Colo., Colorado School of Mines, $30 \mathrm{p}$.

Ratliff, J. R., Williams, F. G., and Hall, J. D., 1971, Applications of the SARABAND sand-shale technique in North America: Society of Professional Well Log Analysts Annual Logging Symposium, 12th, Dallas, Tex., 1971, Transactions, p. P1-P23.

Roberts, H. V., and Campbell, R. L., Jr., 1974, Application of CORIBAND to the micaceous Jurassic sandstones of the northern North Sea basin: Society of Professional Well Log Analysts European Symposium, 3d, London, England, 1974, Transactions, p. D1-D12.

Rudman, A. J., and Blakely, R. F., 1976, Fortran program for correlations of stratigraphic time series: Indiana Geological Survey Occasional Paper 14, 31 p.

Rudman, A. J., Blakely, R. F., and Henderson, G. J., 1975, Frequency domain methods of stratigraphic correlation: American Institute of Mining, Metallurgical, and Petroleum Engineers Offshore Technology Conference, 7th, Houston, Tex., 1975, Proceedings, Paper OTC 2269, p. 265-269.

Rudman, A. J., and Lankston, R. W., 1973, Stratigraphic correlation of well logs by computer techniques: American Association of Petroleum Geologists, v. 57, no. 3, p. 577588.

Schmidt, A. W., and others, 1967, Computerized log analysis for efficiently evaluating gas wells and gas storage reservoirs: Society of Professional Well Log Analysts Annual Logging Symposium, 8th, Denver, Colo., 1967, Transactions, p. S1-S23.

1971, Applications of the CORIBAND technique in complex lithologies: Log Analyst, v. 13, no. 1, p. 19-36.

Schuitz, W. E., and Thadani, S. G., 1981, Applications of digital filtering techniques to nuclear well logs: Society of Professional Well Log Analysts Annual Logging Symposium, 22d, Mexico City, Mexico, 1981, Transactions, p. UU1UU13.

Scientific Software, 1974, LOGCAL, A comprehensive well log analysis system: Denver, Colo., 36 p.

Scott, J. H., 1962, The GAMLOG computer program: U.S. Atomic Energy Commission Report RME 143, 43 p.

1963, Computer analysis of gamma-ray logs: Geophysies, v. 28 , no. 3 , p. $457-465$.

1978, A computer program for borehole compensation of dual-detector density well logs: U.S. Geological Survey Open-File Report 78-515, 7 p. 
1978, A Fortran algorithm for correcting normal resistivity logs for borehole diameter and mud resistivity: U.S. Geological Survey Open-File Report 78-669, 12 p.

1983, Computer analysis of digital well logs: U.S. Geological Survey Circular 879, 13 p.

Shier, D. E., 1975, Analyzing digitized well logs locates Smackover strat traps: World Oil, v. 180, no. 6, p. 66-70.

Souder, W. W., and Pickett, G. R., 1972, A computerized method for the zonation of digitized well logs: Society of Petroleum Engineers of the American Institute of Mining, Metallurgical, and Petroleum Engineers Paper SPE 4019, 8 p.; 1974, Log Analyst, v. 15, no. 3, p. 3-8.

Tixier, M. P., and others, 1965, Automated log computation at well-site-Formation analysis logs: Journal Petroleum Technology, v. 17, p. 11-18.

Tuman, V. S., and Bollman, Dorothy, 1961, Application of computers to the interpretation of well logs: Journal of Petroleum Technology, v. 13, no. 4, p. 311-318.

Vercellino, W. C., and others, 1976, Clastic formation evaluation program in cased holes for both fresh and saline formation waters to determine hydrocarbon content: Petroleum Society, Canadian Institute of Mining Annual Technical Meeting, 27th, Calgary, Canada, 1976, Paper no. 7610, $21 \mathrm{p}$.

Walton, W. C., and Prickett, T. A., 1963, Hydrogeologic electric analog computers: Proceedings of the American Society of Civil Engineers, Journal of the Hydraulies Division, v. 89 , no. HY6, p. 67-91.

Watt, H. B., 1978, Epilogs, a complete analysis of complex and sandstone reservoirs: Dresser Atlas Technical Memorandum, v. 6, no. 1,8 p.

Wells, J. C., and Walstrom, J. E., 1962, A computer program for obtaining approximate porosity and water saturation from resistivity and velocity logs in consolidated sand or sandstone reservoirs: Society of Professional Well Log Analysts Annual Logging Symposium, 3d, Houston, Tex., 1962, Transactions, p. 1-15.

Wilson, D. A., and Hensel, W. M., 1976, Computer log analysis + core = improved formation evaluation in West Howard-Glasscock unit: Society of Petroleum Engineers of the American Institute of Mining, Metallurgical, and Petroleum Engineers Paper SPE 6188, 12 p.

Zangwill, John, 1982, Depth matching-A computerized approach: Society of Professional Well Log Analysts Annual Logging Symposium, 23d, Corpus Christi, Tex., 1982, Transactions, p. EE1-EE17.

\section{CORE}

Aufricht, W. R., and Koepf, E. H., 1957, The interpretation of capillary pressure data from carbonate reservoirs: Journal of Petroleum Technology, Technical Note 442, v. 9, no. 10 , p. $1-4$.

Collins, H. N., 1974, Log-core correlations in the Athabasca oil sands: Society of Petroleum Engineers of the American Institute of Mining, Metallurgical, and Petroleum Engineers Paper SPE 5037, 18 p.

Corey, J. C., and Hayes, D. W., 1970, Determination of density and water content of marine sediment in an unextruded core using fast neutron and gamma ray attenuation: Deep-Sea Research, v. 17, no. 5, p. 917-922.
Czubek, J. A., 1976, Comparison of nuclear well logging data with the results of core analysis: International Atomic Energy Agency Panel on Nuclear Techniques in Geochemistry and Geophysics, Vienna, Austria, 1976, Proceedings, p. 93-106.

Evans, W. M., 1973, A system for combined determination of dynamic and static elastic properties, permeability, porosity, and resistivity of rocks [University of Texas, $\mathrm{Ph}$. D. dissertation]: University Microfilms, International, Publication 75-4491, 247 p.

Gauntt, J. C., and Jenkins, R. E., 1963, The use of core analysis data to explain the abnormally low resistivities of some hydrocarbon-productive Simpson Series sands in central Oklahoma: Society of Professional Well Log Analysts Annual Logging Symposium, 4th, Oklahoma City, Okla., 1963, Transactions, p. XV1-XV24.

Granberry, R. J., and Wilshusen, R. C., 1962, Improved interpretation of formation productivity by combined use of core analysis and electric log data: Gulf Coast Association of Geological Societies Transactions, v. 12, p. 213-221.

Hunt, G. R., and others, 1979, Initial report of the Petrophysics Laboratory: U.S. Geological Survey Circular $789,74 \mathrm{p}$.

Jorda, R. M., 1980, Use of data obtained from core tests in the design and operation of spent brine injection wells in geopressured or geothermal systems: Sandia National Laboratory, issued by the U.S. Department of Commerce, National Technical Information Service, Report SAND80 $7047,160 \mathrm{p}$.

Keller, G. V., 1981, Elastic, mechanical, and electrical properties of low-porosity rocks: Log Analyst, v. 22, no. 6, p. 13-21.

Koepf, E. H., and Granberry, R. J., 1961, The use of sidewall core analysis in formation evaluation: Journal of Petroleum Technology, v. 13 , no. 5, p. 419-424.

Lee, J. W., 1971, Well bore storage-How it affects pressure buildup and pressure drawdown tests: Society of Professional Well Log Analysts Annual Logging Symposium, 12th, Dallas, Tex., 1971, Transactions, p. E1-E15.

Marchant, L. C., and White, E. J., 1968, Comparison of $\log$ and core analysis results for an extremely heterogeneous carbonate reservoir: Society of Professional Well Log Analysts Annual Logging Symposium, 9th, New Orleans, La., 1968, Transactions, p. L1-L16.

Mattax, C. C., McKinley, R. M., and Clothier, A. T., 1975, Core analysis of unconsolidated and friable sands: Journal of Petroleum Technology, v. 27, no. 12, p. 1423-1432.

Miesch, E. P., and Albright, J. C., 1967, A study of invasion diameter: Society of Professional Well Log Analysts Annual Logging Symposium, 8th, Denver, Colo., 1967, Transactions, p. 01-014.

Reudelhuber, F. O., and Furen, J. E., 1957, Interpretation and application of side wall core analysis data: Gulf Coast Association of Geological Societies Transactions, v. 7, p. 83-87.

Swanson, B. F., and Thomas, E. C., 1980, The measurement of petrophysical properties of unconsolidated sand cores: Log Analyst, v. 21, no. 5, p. 22-31.

Trudgen, Patricia, and Hoffman, Frank, 1967, Statistically analyzing core data: Journal of Petroleum Technology, v. 19 , no. 4, p. $497-503$. 


\section{CROSS PLOTtNinc}

Bateman, R. M., 1977, The fluid identification plot: Society of Professional Well Log Analysts Annual Logging Symposium, 18th, Houston, Tex., 1977, Transactions, p. C1C16.

Burke, J. A., Schimdt, A. W., and Campbell, R. L., Jr., 1969, The litho-porosity cross plot-A method of determining rock characteristics for computation of log data [abs.]: Society of Professional Well Log Analysts Annual Logging Symposium, 10th, Houston, Tex., 1969, Transactions, p. Y1.

Lang, W. H., Jr., 1973, Porosity-resistivity cross-plotting: Log Analyst, v. 14, no. 1, p. 16-20.

McFadzean, T. B., 1972, Cross-plotting-A neglected technique in log analysis: Canadian Well Logging Society Journal, v. 5, no. 1 , p. 69-99.

Pickett, G. R., and Ikwuakor, K. C., 1979, Interrelations, integration, and interpretational intercourse: Canadian Well Logging Society Formation Evaluation Symposium, 7th, Calgary, Canada, 1979, Transactions, p. U1-U16.

Sanyal, S. K., 1973, Formation evaluation from conventional well logs in the Gulf Coast area: Society of Petroleum Engineers of the American Institute of Mining, Metallurgical, and Petroleum Engineers Paper SPE 4641, 12 p.

Sanyal, S. K., and Ellithorpe, J. E., 1978, A generalized resistivity-porosity crossplot concept: Society of Petroleum Engineers of the American Institute of Mining, Metallurgical, and Petroleum Engineers Paper SPE 7145, 10 p.

\section{DIELECTRIC MEASUREMENTS}

Freedman, R., and Vogiatzis, J. P., 1979, Theory of microwave dielectric constant logging using the electromagnetic wave propagation method: Geophysics, v. 44 , no. 5, p. 969-986.

Hall, H. E., 1981, Potential use of dielectric constant log as exploration tool: Oil and Gas Journal, v. 79, no. 4, p. 276281.

Lysne, P. C., and others, 1981, Dielectric log interpretationProberesponses and dielectric properties of rocks: U.S. Department of Commerce, National Technical Information Service, Report CONF-810616-1, 16 p.

Meador, R. A., and Cox, P. T., 1975, Dielectric constant logging, a salinity independent estimation of formation water volume: Society of Petroleum Engineers of the American Institute of Mining, Metallurgical, and Petroleum Engineers Paper SPE 5504, $15 \mathrm{p}$.

Poley, J. P., Nooteboom, J. J., and deWaal, P. J., 1978, Use of V. H. F. dielectric measurements for borehole formation analysis: Log Analyst, v. 19, no. 3, p. 8-30.

Wharton, R. P., and Delano, J. M., 1981, An EPT interpretation procedure and application in fresh water, shaly, oil sands: Society of Professional Well Log Analysts Annual Logging Symposium, 22d, Mexico City, Mexico, 1981, Transactions, p. E1-E28.

\section{DIGITIZING LOGS}

Arnoult, E. B., Jr., 1974, Logical considerations in well log digitizing: Log Analyst, v. 15, no. 2, p. 3-17.
Best, D.L., Gardner, J. S., and Dumanoir, J. L., 1978, A computer-wellsite log computation: Society of Professional Well Log Analysts Annual Logging Symposium, 19th, El Paso, Tex., 1978, Transactions, p. Z1-Z32.

Brown, M. P., Hynes, S. D., and Wedderburn, L. A., 1981, Guidebook to the South Florida Water Management District's geophysical logging and digitized data processing techniques: South Florida Water Management District, Groundwater Division Technical Memorandum, 112 p.

Browne, E. J. P., 1973, Interactive graphics and data storage in large scale log analysis: Society of Petroleum Engineers of the American Institute of Mining, Metallurgical, and Petroleum Engineers Paper SPE 4426, 12 p.

Connolly, E. T., 1975, Digital log analysis-Recognition and treatment of field recording errors: Log Analyst, v. 16, no. 2, p. 13-32.

Crosby, J. W., III, and Logan, J. D., 1967, A data acquisition system for radiation well logs: American Geophysical Union Pacific Northwest Region Annual Meeting, 14th, Moscow, Idaho, 1967, Proceedings, p. 1-22.

Eaton, F. M., and Decker, G. J., 1965, Digital transmission of well logs by radio and telephone: Society of Petroleum Engineers of the American Institute of Mining, Metallurgical, and Petroleum Engineers Paper SPE 1325, 7 p.

Gearhart, Marvin, Hallenburg, J. K., and Foote, R. S., 1970, Well site digitizing equipment for mineral exploration: Society of Petroleum Engineers of the American Institute of Mining, Metallurgical, and Petroleum Engineers Paper SPE 2923, $12 \mathrm{p}$.

Gordon, Edward, 1962, Automatic digitizing of well logs: Society of Professional Well Log Analysts Annual Logging Symposium, 3d, Houston, Tex., 1962, Transactions, p. 123.

Hancock, R. L., and Bowden, J. C., 1981, Design of a borehole data-acquisition transmission system: U.S. Department of Energy, issued by the U.S. Department of Commerce, National Technical Information Service, Report DE81028936, $185 \mathrm{p}$.

Keys, W. S., 1967, Magnetic tape recording of geophysical logs, in Geological Survey Research, 1967: U.S. Geological Survey Professional Paper 575-C, p. C242-C246.

Lang, J. G., 1966, Moderate speed data logging using pulse groups on magnetic tape: Electronic Engineering, v. 38, no. 460 , p. $381-383$.

Neinast, G. S., and Knox, C. C., 1974, Normalization of well log digitizing: Log Analyst, v. 15, no. 2, p. 19-25.

Tinch, D. H., and others, 1965, Application of magnetic tapes to well logging: Society of Petroleum Engineers of the American Institute of Mining, Metallurgical, and Petroleum Engineers Paper SPE 1182, $10 \mathrm{p}$.

Work, P. L., Simmons, R. W., and Foster, J. T., 1976, Digitized logs evaluate data in raw form from existing fields to show reservoir parameters: Oil and Gas Journal v. 74, no. 6, p. 63-64.

Work, P. L., Stevens, O. D., and Meadow, H. M., 1972, Digital well $\operatorname{logs}+$ digital computer $=$ exploration tool: Oil and Gas Journal, v. 70, no. 7, p. 112-118.

Work, P. L., Stevens, O. D., and Simmons, R. W., 1974, Digitized well logs in Morrow sand exploration: Oil and Gas Journal, v. 72, no. 7, p. 61-63. 


\section{DIPMETER}

Bricaud, J. M., and Poupon, Andre, 1959, Continuous dipmeter survey, the poteclinometer and the micro-focused devices: World Petroleum Congress Meeting, 5th, New York, 1959, Proceedings, p. 1-9.

Cox, J. W., 1970, The high resolution dipmeter reveals dip-related borehole and formation characteristics: Society of Professional Well Log Analysts Annual Logging Symposium, 11th, Los Angeles, Calif., 1970, Transactions, p. D1-D25.

Fitzgerald, D. D., Theriod, J. C., and York, P. L., 1980, Dipmeter validity in deviated boreholes: Log Analyst, v. 21, no. 3, p. 8-18.

Gilreath, J. A., and Maricelli, J. J., 1971, Detailed stratigraphic control through dip computations: Bulletin of the American Association of Petroleum Geologists, v. 48, no. 12, p. 1902-1910.

Hepp, V., and Dumestre, A. C., 1975, Cluster-A method for selecting the most probable dip results from dipmeter surveys: Society of Petroleum Engineers of the American Institute of Mining, Metallurgical, and Petroleum Engineers Paper SPE 5543, 17 p.

Holt, O. R., 1972, Structural geologic considerations in diplog interpretation: Society of Professional Well Log Analysts Annual Logging Symposium, 13th, Tulsa, Okla., 1972, Transactions, p. Q1-Q30.

Holt, O. R., Schoonover, L. G., and Wichmann, P. A., 1977, True vertical depth, true vertical thickness and true stratigraphical thickness logs: Society of Professional Well Log Analysts Annual Logging Symposium, 18th, Houston, Tex., 1977, Transactions, p. Y1-Y19.

Marshall, A. G. B., 1976, The "cluster" program applied to dipmeter interpretation in South East Asia: South East Asia Petroleum Exploration Society, v. 3, p. 50-72.

Matthews, R. R., and others, 1965, Supplementary computer programs for dipmeter analysis: Society of Professional Well Log Analysts Annual Logging Symposium, 6th, Dallas, Tex., 1965, Transactions, v. 2, p. D1-D19.

Moran, J. H., and others, 1961, Automatic computation of dipmeter logs digitally recorded on magnetic tapes: Society of Petroleum Engineers of the American Institute of Mining, Metallurgical, and Petroleum Engineers Paper SPE 174, 19 p.

Rider, M. H., 1978, Dipmeter log analysis-An essay: Society of Professional Well Log Analysts Annual Logging Symposium, 19th, El Paso, Tex., 1978, Transactions, p. G1G18.

Schooner, L. G., 1973, Accurate method of low angle dip calculations: Society of Professional Well Log Analysts Annual Logging Symposium, 14th, Lafayette, La., 1973, Transactions, p. S1-S15.

Shields, C., 1974, The dipmeter used to recognize depositional environments: Society of Professional Well Log Analysts European Symposium, 3d, London, England, 1974, Transactions, p. H1-H12.

Vincent, Ph., Gartner, J. E., and Attali, G., 1979, An approach to detailed dip determination using correlation by pattern recognition: Journal of Petroleum Technology, v. 31 , no. 2, p. 232-240.

\section{DIRECTIONAL SURVEY}

Dailey, Patrick, 1977, A guide to wellbore survey calculations: Drilling, v. 38 , no. 8 , p. 52, 53, 56, 57, 59, $118,119$.

Peveraro, Roberto, 1979, Vertical depth correction methods for deviation survey and well log interpretation: Society of Professional Well Log Analysts European Symposium, 6th, London, England, 1979, Transactions, p. P1-P22.

Wilson, G. J., 1968, An improved method for computing directional surveys: Journal of Petroleum Technology, v. 20, no. 8 , p. $871-876$.

\section{ELASTIC MODULI}

Kumar, J., 1976, The effect of Poisson's ratio on rock properties: Society of Petroleum Engineers of the American Institute of Mining, Metallurgical, and Petroleum Engineers Paper SPE 6094, 6 p.

Myung, J. I.; and Helander, D. P., 1972, Correlation of elastic moduli dynamically measured by in-situ and laboratory techniques: Log Analyst, v. 13, no. 6, p. 22-33.

\section{ELECTROMACNETICS}

Calvert, T. J., Rau, R. N., and Wells, L. E., 1977, Electromagnetic propagation-A new dimension of logging: Society of Petroleum Engineers of the American Institute of Mining, Metallurgical, and Petroleum Engineers Paper SPE 6542, $15 \mathrm{p}$.

Cook, J. C., 1970, Electromagnetic exploration within salt domes: Northern Ohio Geological Society Symposium on Salt, 3d, Cleveland, Ohio, 1970, Proceedings, v. 2, p. 386390.

Dyck, A. V., 1981, A method for quantitative interpretation of wideband, drill-hole EM surveys in mineral exploration [University of Toronto, $\mathrm{Ph}$. D. dissertation]: Research in Applied Geophysies, no. 23, 170 p.

Dyck, A. V., and West, G. F., 1979, The use of simple models in interpreting drillhole EM surveys in mineral exploration: Society of Exploration Geophysicists Annual Meeting, 49th, New Orleans, La., 1979, Proceedings, p. 1-30.

Lytle, R. J., and others, 1978, Electromagnetic cross-borehole survey of a site proposed for an urban transit station: Lawrence Livermore Laboratory, issued by the U.S. Department of Commerce, National Technical Information Service, Report UCRL-52484, 19 p.

Wharton, R. P., and Delano, J. M., Jr., 1981, An EPT interpretation procedure and application in fresh water, shaly, oil sands: Society of Professional Well Log Analysts Annual Logging Symposium, 22d, Mexico City, Mexico, 1981, Transactions, p. E1-E28.

Wharton, R. P., and others, 1980, Electromagnetic propagation logging-Advances in technique and interpretation: Society of Petroleum Engineers of the American Institute of Mining, Metallurgical, and Petroleum Engineers Paper SPE 9267, $12 \mathrm{p}$.

\section{FLOWMETERS}

Arnold, J. S., 1950, An electromagnetic flowmeter for transient flow studies: Scientific Instruments, v. 22, no. 1, p. 43-47. 
Bates, Audie, and Blanks, G. L., 1977, Application of a trifunctional annular production $\log$ in deep wells in west Texas and New Mexico: Southwestern Petroleum Short Course Association Annual Meeting, Lubbock, Tex., 1977, Proceedings, p. $63-68$.

Bennett, G. D., and Patten, E. P., Jr., 1960, Borehole geophysical methods for analyzing specific capacity of multiaquifer wells: U.S. Geological Survey Water-Supply Paper 1536-A, p. 1-25.

Bird, J. M., and Bullard, H. M., 1961, Use of subsurface flowmeter and fluid density analyzer for studying fluid flow in producing and injection wells: University Petroleum Engineering Conference, Urbana, Ill., 1961, Proceedings, p. $1-4$.

Britt, E. L., 1976, Theory and applications of the borehole audio tracer survey: Society of Professional Well Log Analysts Annual Logging Symposium, 17th, Denver, Colo., 1976, Transactions, p. BB1-BB35.

Brown, A. E., 1969, Today's ultrasonic flowmeter is a versatile measuring tool: Oil and Gas Journal, v. 67, no. 34, p. 9295.

Chapman, H. T., and Robinson, A. E., 1962, A thermal flowmeter for measuring velocity of flow in a well: U.S. Geological Survey Water-Supply Paper 1544-E, p. E1E12.

Dudgeon, C. R. Green, M. J., and Smedmor, W. J., 1975, Heat-pulse flowmeter for boreholes: England, Medmenham, Marlow, Bucks, Water Research Centre Technial Report TR4, $69 \mathrm{p}$.

Fowlis, W. W., and others, 1971, The measurement of time-dependent fluid temperature and flow speed fields-Techniques, apparatus and results: Pittsburgh, Pa., Symposium on Flow, Paper no. 2-2-54, 23 p.

Godbey, J. K., 1962, New flowmeter gives water-injection profiles: Oil and Gas Journal, v. 60, no. 11, p. 92-95.

Hess, A. E., 1982, A heat-pulse flowmeter for measuring low velocities in boreholes: U.S. Geological Survey Open-File Report 82-699, 44 p.

James, W. G., 1951, An induction flowmeter design suitable for radioactive liquids: Scientific Instruments, v. 22, no. 12 , p. 989-1002.

Kading, H. W., 1976, Horizontal-spinner-A new production logging technique: Log Analyst, v. 17, no. 5, p. 3-7.

Matveev, B. K., 1958, Determination of the velocity and direction of flow of ground waters for the data of a single well: Razvedka I Okhrana Nedr 24 , no. 12, p. 44-47, and Glen Ridge, N. J., Associated Technical Services, Inc., p. 1-4.

McKinley, R. M., Bower, F. M., and Rumble, R. C., 1972 , The structure and interpretation of noise from flow behind cemented casing: Society of Petroleum Engineers of the American Institute of Mining, Metallurgical, and Petroleum Engineers SPE Paper 3969, p. 1-12.

Oil and Gas Journal, 1971, Flowmeter promises high accuracy: v. 69 , no. 34 , p. $115-116$.

Piety, T. G., and Wiley, B. F., 1952, Flowmeter for water injectivity profiling: World Oil, v. 134, no. 6, p. 176-188.

Schimschal, Ulrich, 1981, Flowmeter analysis at Raft River, Idaho: Ground Water, v. 19, no. 1, p. 93-97.

Selecki, A., and Filipek, S., 1966, The single-well method for determining the direction of flow of ground-water using a neutron source: International Journal of Applied Radiation and Isotopes, Technical Notes, v. 17, p. 351-352.
Slichter, C. S., 1905, Description of underflow meter used in measuring the velocity and direction of movement of underground water, in Fuller, M. L., ed., Contributions to the hydrology of eastern United States, 1904: U.S. Geological Survey Water-Supply Paper 110, p. 17-31.

Smoot, G. F., and Novak, C. E., 1968, Calibration and maintenance of vertical-axis type current meters: U.S. Geological Survey Techniques of Water-Resources Investigations, Book 8, Chapter B2, 15 p.

Syms, M. C., 1980, Interpretation of flowmeter and temperature logs from geothermal wells: New Zealand, Department of Scientific and Industrial Research Report 168, 63 p.

1982, Down hole flowmeter analysis using an associated caliper log: Ground Water, v. 20, no. 5, p. 606-610.

Syms, M. C., and Syms, P. H., 1981, Water flow and temperature logs from wells in the Wairakei and Broadlands geothermal fields: New Zealand Department of Scientific and Industrial Research, Geophysics Division Report 183, 84 p.

Syms, M. C., Syms, P. H., and Bixley, P. F., 1982, Interpretation of flow measurement in geothermal wells without caliper data: Log Analyst, v. 23, no. 2, p. 34-45.

Thomas, H. E., 1971, The hot-film flow $\log -\mathrm{A}$ formation evaluation tool designed for shallow in-situ oil shale experiments: Society of Petroleum Engineers of the American Institute of Mining, Metallurgical, and Petroleum Engineers Paper SPE 3501, 12 p.

Thomas, H. E., and Sterner, T. E., 1972, Hot-film flow logging as applied to in-situ oil shale and mining experiments: Society of Professional Well Log Analysts Annual Logging Symposium, 13th, Tulsa, Okla., 1972, Transactions, p. L1-L14.

Turkowa, Boguslawa, and otners, 1967, A single-well method for determining the direction and velocity of flow of underground waters-Results of in-the-field investigations: Nukleonika, v. 12 , no. 1-2, p. 55-61.

Van Rooy, D. L., and Vesperman, F. A., 1981, A generalized, constrained, N-pass method for interpreting FBS and CFS flowmeters: Society of Professional Well Log Analysts Annual Logging Symposium, 22d, Mexico City, Mexico, 1981, Transactions, p. W1-W21.

Witterholt, E. J., and Fischer, J. S., 1972, The utility of flowprofile logging for interpretation of pressure tests: Society of Professional Well Log Analysts Annual Logging Symposium, 13th, Tulsa, Okla., 1972, Transactions, p. S1-S17.

Wurzel, P., and Ward, P. R. B., 1965, Measurement with radio-active isotopes of groundwater flow direction in a single borehole: The Rhodesia, Zambia, and Malawi Journal of Agricultural Research, v. 3, no. 2, p. 87-93.

\section{FLUID CONDUCTIVITY AND RESISTIVITY}

Alger, R. P., 1964, Interpretation of electric logs in fresh water wells in unconsolidated formations: Society of Professional Well Log Analysts Annual Logging Symposium, 7th, Tulsa, Okla., 1966, Transactions, p. CC1-CC25.

Brown, K. W., 1940, Use and limitations of conductivity measurements of well water quality: Journal of the American Water Works Association, v. 32, no. 4, p. 675-687. 
Denver Well Logging Society, 1964, Rocky Mountain formation water resistivities: Denver, Colo., Petroleum Information, $117 \mathrm{p}$.

Desai, K. P., and Moore, E. J., 1969, Equivalent $\mathrm{NaCl}$ determination from ionic concentrations: Log Analyst, v. 10, no. 3 , p. 12-21.

MacCary, L. M., 1980, Use of geophysical logs to estimate water-quality trends in carbonate aquifer: U.S. Geological Survey Water-Resources Investigations 80-57, $29 \mathrm{p}$.

1981, Apparent water resistivity, porosity, and groundwater temperature of the Madison Limestone and underlying rocks in parts of Montana, Nebraska, North Dakota, South Dakota, and Wyoming: U.S. Geological Survey Open-File Report 81-629, 43 p.

Moore, E. J., 1966, A graphic description of new methods for determining equivalent $\mathrm{NaCl}$ concentration from chemical analysis: Society of Professional Well Log Analysts Annual Logging Symposium, 7th, Tulsa, Okla., 1966, Transactions, p. M1-M34.

Oduolowu, O. A., 1977, A case study of the determination of connate water resistivity, $R_{w}$, by repeat logging, in the Powder River basin, Wyoming: Log Analyst, v. 18, no. 6, p. $27-31$.

Schuster, C. L., and Dobecki, T. L., 1979, Instrumentation for formation evaluation and advanced logging techniques: Sandia National Laboratory, issued by the U.S. Department of Commerce, National Technical Information Service, Report SAND-79-0313, 16 p.

Society of Professional Well Log Analysts, 1969, Formation water resistivity data South Louisiana, offshore and adjacent areas: Lafayette, La., Lafayette Chapter, $67 \mathrm{p}$.

Tate, T. K., and Robertson, A. S., 1971, Investigations into high salinity groundwater at the Woodfield Pumping Station, Wellington, Shropshire: Natural Environment Research Council, Water Supply Papers of the Institute of Geological Sciences, Research Report 6, 21 p.

Tate, T. K., Robertson, A. S., and Gray, D. A., 1971, Borehole logging investigations in the Chalk of the Lambourn and Winterbourne valleys of Berkshires: Natural Environment Research Council, Water Supply Papers of the Institute of the Geological Sciences, Research Report 5,23 p.

\section{FORMATION FACTOR}

Carothers, J. E., 1968, A statistical study of the formation factor relation: Log Analyst, v. 9, no . 5, p. 13-20.

Newcome, Roy, Jr., 1975, Formation factors and their use in estimating water quality in Mississippi aquifers: U.S. Geological Survey Water-Resources Investigations 2-75, issued by the U.S. Department of Commerce, National Technical Information Service, Report PB-242 801/AS, 17 p.

Perez-Rosales, Candelario, 1975, Generalization of Maxwell equation for formation factors: Society of Petroleum Engineers of the American Institute of Mining, Metallurgical, and Petroleum Engineers Paper SPE 5502, 10 p.

Porter, C. R., and Carothers, J. E., 1970, Formation factorporosity relation derived from well log data: Society of Professional Well Log Analysts Annual Logging Symposium, 11th, Los Angeles, Calif., 1970, Transactions, p. A1-A19.
Raiga-Clemenceau, Jean, 1977, The cementation exponent in the formation factor-porosity relations-The effect of permeability: Society of Professional Well Log Analysts Annual Logging Symposium, 18th, Houston, Tex., 1977, Transactions, p. R1-R13.

Rivero-Gomez, Orlando, 1978, The formation resistivity factor-A qualitative permeability tool: Petroleum Engineer International, v. 50, no. 1, p. 91-98.

Sawyer, W. K., Pierce, C. I., and Lowe, R. B., 1971, Electrical and hydraulic flow properties of Appalachian petroleum reservoir rocks: Ontario Petroleum Institute, Inc., Annual Conference, 10th, Toronto, Canada, 1971, Proceedings, Technical Paper 5, 22 p.

\section{FRACTURES}

Aguilera, Roberto, 1973, Detection and evaluation of naturally fractured reservoirs from logs: Society of Petroleum Engineers of the American Institute of Mining, Metallurgical, and Petroleum Engineers Paper SPE 4398, 8 p.

Aguilera, Roberto, and Acevedo, Luis, 1982, FCL-A computerized well-log interpretation process for the evaluation of naturally fractured reservoirs: Journal of Canadian Petroleum Technology, v. 21, no. 1, p. 31-37.

Aguilera, Roberto, and van Poolen, H. K., 1977, Current status on the study of naturally fractured reservoirs: Log Analyst, v. 18, no. 3, p. 3-23.

1978, Geologic aspects of naturally fractured reservoirs explained: Oil and Gas Journal, v. 76 , no. 51, p. 46-51.

1978, How to evaluate naturally fractured reservoirs from various well logs: Oil and Gas Journal, v. 76, no. 52, p. 202-208.

Babcock, E. A., 1978, Measurement of subsurface fractures from dipmeter logs: Bulletin of the American Association of Petroleum Geologists, v. 62, no. 7, p. 1111-1126.

Denoo, Stan, 1978, Several ways exist for locating reservoir fractures: Oil and Gas Journal, v. 76, no. 41, p. 80-82.

Etnyre, Lee, 1981, Fracture identification in the Panoma Field Council Grove formation: Log Analyst, v. 22, no. 6, p. 3-6.

Evans, R. D., and McGhee, John, 1981, Characterization of fluid flow in naturally fractured reservoirs: U.S. Department of Energy, issued by the U.S. Department of Commerce, National Technical Information Service, Report $\mathrm{DOE} / \mathrm{BC} / 10255-4,53 \mathrm{p}$.

Fraser, C. D., and Pettitt, B. E., 1962, Results of a field test to determine the type and orientation of a hydraulically induced formation fracture: Journal of Petroleum Technology, v. 14 , no. 5 , p. $463-466$.

Gowd, T. N., and Rummel, F., 1980, Effect of confining pressure on fracture behavior of a porous rock: International Journal of Rock Mechanics, Mineral Sciences, and Geomechanics Abstracts, v. 17, no. 4, p. 225-229.

Haartenbaum, B. A., and Rawson, G., 1980, Topical report on subsurface fracture mapping from geothermal wellbores: U.S. Department of Energy, issued by the U.S. Department of Commerce, National Technical Information Service, Report DOE/ET/27013-T1, 131 p.

Heflin, J. D., 1979, Fracture detection in West Coast reservoirs using well logs: Society of Petroleum Engineers of the American Institute of Mining, Metallurgical, and Petroleum Engineers Paper SPE 7976, 16 p. 
Kehrman, R. F., 1978, Fracture characterization study: Boulder, Colo., Westinghouse Electric Corp., 24 p.

Keys, W. S., 1980, The application of the acoustic televiewer to the characterization of hydraulic fractures in geothermal wells: Geothermal Resources Council Geothermal Reservoir Stimulation Symposium, San Francisco, Calif., 1980, Proceedings, p. 176-202.

King, M. S., and McConnell, B. V., 1973, Fracture evaluation with acoustic logs in dry boreholes: Symposium on Rock Mechanics, 15th, Custer State Park, S. Dak., 1973, Proceedings, p. 273-292.

Kintzinger, P. R., West, F. G., and Aamodt, R. L., 1977, Downhole electrical detection of hydraulic fractures in GT2 and EE-1: Los Alamos Scientific Laboratory, issued by the U.S. Department of Commerce, National Technical Information Service, Report LA-6890-MS, 13 p.

Koelle, A. R., and Landt, J. A., 1980, Induction logging device: U.S. Department of Commerce, National Technical Information Service, Report PAT-APPL 6-607 856, 24 p.

Ladeira, F. L., and Price, N. J., 1981, Relationship between fracture spacing and bed thickness: Journal of Structural Geology, v. 3, no. 2, p. 179-183.

McCoy, R. L., Kumar, R. M., and Pease, R. W., 1980, Identifying fractures with conventional well logs: World Oil, v. 191, no. 7 , p. 91-98.

Myung, J. I., and Caldwell, John, 1971, Fracture investigation by wireline logging methods: Ontario Petroleum Institute, Inc., Annual Conference, 10th, Ontario, Canada, 1971, Technical Paper 9, 26 p.

Paillet, F. L., 1980, Acoustic propagation in the vicinity of fractures which intersect a fluid-filled borehole: Society of Professional Well Log Analysts Annual Logging Symposium, 21st, Lafayette, La., 1980, Transactions, p. DD1DD33.

1981, A comparison of fracture characterization techniques applied to near-vertical fractures in a limestone reservoir: Society of Professional Well Log Analysts Annual Logging Symposium, 22d, Mexico City, Mexico, 1981, Transactions, p. XX1-XX29.

Ramirez, A. L., Deadrick, F. J., and Lytle, R. J., 1982, Crossborehole fracture mapping using electromagnetic geotomography: Lawrence Livermore Laboratory, issued by the U.S. Department of Commerce, National Technical Information Service, Report UCRL-53255, 58 p.

Rasmus, J. C., 1981, Fluid evaluation of fracture hydrocarbon intervals in the Twin Creek formation of the Yellow Creek field: Society of Petroleum Engineers/Department of Energy Low Permeability Symposium, Denver, Colo., 1981, Paper SPE/DOE 9857, p. 301-304.

Rigby, F. A., 1980, Fracture identification in an igneous geothermal reservoir-Surprise Valley, California: Society of Professional Well Log Analysts Annual Logging Symposium, 21st, Lafayette, La., 1980, Transactions, p. Z1Z9.

Shanks, R. T., and others, 1976, A review of fracture detection with well logs: Society of Petroleum Engineers of the American Institute of Mining, Metallurgical, and Petroleum Engineers Paper SPE 6159, 16 p.
Smith, M. B., and others, 1976, The azimuth of deep, penetrating fractures in the Wattenberg field: Society of Petroleum Engineers of the American Institute of Mining, Metallurgical, and Petroleum Engineers Paper SPE 6092, $12 \mathrm{p}$.

Stierman, D. J., Healy, J. H., and Kovach, R. L., 1979, Pressure-induced velocity gradient-An alternative to a Pg refractor in the Gabilan Range, central California: Bulletin of the Seismological Society of America, v. 69, no. 2, p. $397-415$.

Suau, Jean, and Gartner, J. E., 1980, Fracture detection from well logs: Log Analyst, v. 21, no. 2, p. 3-13.

Walker, Terry, and Kessler, Calvin, 1977, Detection of natural fractures with well logs: Houston, Tex., Halliburton Company, Welex Division, Report L-38, 11 p.

Warpinski, N. R., and others, 1981, Direct observation of a sand-propped hydraulic fracture: Sandia National Laboratory, issued by the U.S. Department of Commerce, National Technical Information Service, Report SAND 81$0225,63 \mathrm{p}$.

Williams, G. B., 1970, Sonic principles applied to formation fracture location and cement bond logging: Canadian Well Logging Society Journal, v. 3, no. 1, p. 7-15.

\section{GAMMA}

Blanchard, A., and Dewan, J. T., 1953, The calibration of gamma ray logs: Petroleum Engineer, v. 25, no. 9, p. B76B80.

Bunker, C. M., 1965, Subsurface measurements of natural gamma radioactivity, Nevada Test Site and vicinity, Nye, Lincoln, and Clark Counties, Nevada: U.S. Geological Survey Report TEI-858, $74 \mathrm{p}$.

Campbell, J. L. P., 1951, Radioactivity well logging anomalies: Petroleum Engineer, v. 23, no. 6, p. B7-B12.

Conaway, J. G., 1980, Direct determination of the gamma-ray logging system response function in field boreholes: Geoexploration, v. 18, p. 187-199.

Conaway, J. G., Bristow, Quentin, and Killeen, P. G., 1980, Optimization of gamma-ray logging techniques for uranium: Geophysics, v. 45, no. 2, p. 292-311.

Conaway, J. G., and Killeen, P. G., 1978, Quantitative uranium determinations from gamma-ray logs by application of digital time series analysis: Geophysics, v. 43, no. 6, p. 1204-1221.

Czubek, J. A., 1962, Natural gamma-ray logging for the density logging purposes: Nuclear Geophysicists Conference, Cracow, Poland, 1962, Proceedings, v. 1, p. 289-302.

1962, Quantitative interpretation of gamma-ray logs: Nuclear Geophysicists Conference, Cracow, Poland, 1962, Proceedings, v. 1, p. 237-274.

1968, Natural selective gamma logging, a new log of direct uranium determination: Nukleonika, v. 13, no. 1 , p. 89-105.

Dahl, J. B., and Odegaard, H., 1970, Areal measurements of water equivalent of snow deposits by means of natural radioactivity in the ground, in Isotopes in hydrology: International Atomic Energy Symposium, Vienna, Austria, 1970, proceedings, p. 191-210.

Donovan, W. S., and Hilchie, D. W., 1981, Natural gamma ray emissions in the muddy $\mathrm{J}$ formation in eastern Wyoming: Log Analyst, v. 22, no. 2, p. 17-22. 
Droullard, R. F., and Dodd, P. H., 1965, Gamma-ray logging techniques in uranium evaluation: Grand Junction, U.S. Atomic Energy Commission, Operations Branch Technical Memorandum 232, $22 \mathrm{p}$.

Duray, J. R., 1976, A brief review of the basis for, and the procedures currently utilized in, gross gamma-ray log calibration: Bendix Field Engineering Corporation, issued by the U.S. Department of Commerce, National Technical Information Service, Report GJBX-61, 13 p.

Fowler, Fred, 1958, Radiometric, instruments-types, uses and reliability: Wyoming Mining Association Meeting, Casper, Wyo., 1958, Proceedings, p. 1-5.

Granberry, R. J., Jenkins, R. E., and Bush, D. C., 1968, Grain density values of cores from some Gulf Coast formations and their importance in formation evaluation: Society of Professional Well Log Analysts Annual Logging Symposium, 9th, New Orleans, La., 1968, Transactions, p. N1-N19.

Hale, L. A., 1967, Phosphate exploration using gamma-radiation logs, Dry Valley, Idaho, in Anatomy of the western phosphate field: Intermountain Association of Geologists Annual Field Conference, 15th, 1967, Guidebook, p. 147159.

Hallenburg, J. K., 1973, Interpretation of gamma ray logs: Log Analyst, v. 16, no. 6, p. 3-12.

Hawkins, W. K., and Gearhart, Marvin, 1968, Use of logging in uranium prospecting: Society of Professional Well Log Analysts Annual Logging Symposium, 9th, New Orleans, La., 1968, Transactions, p. T1-T13.

Heslop, A., 1974, Gamma-ray log response of shaly sandstones: Log Analyst, v. 15, no. 5, p. 17-21.

Johnstone, C. W., 1965, Detection of natural gamma radiation in petroleum exploration boreholes, in Adams, J. A. S., and Lowder, W. M., eds., The natural radiation environment: Chicago, University of Chicago Press, p. 115-127.

Killeen, P. G., 1982, Gamma-ray logging and interpretation, in Fitch, A. A., ed., Developments in geophysical exploration methods-3: London, England, Elsevier Applied Science Publishers, p. 95-150.

Killion, H. W., 1966, Fluid migration behind casing revealed by gamma ray logs: Log Analyst, v. 6, no. 5, p. 46-49.

Kokesh, F. P., 1951, Gamma-ray logging: Oil and Gas Journal, v. 50 , no. 12 , p. $284-301$.

Larionov, V. V., 1963, Experience in using radiometric data from drill holes for evaluating reservoir properties of beds in the search for subsurface stores of gas in the Kaluga region: New York, Consultants Bureau Enterprises, Inc., Transactions of the Ministry of Intermediate and Higher Specialized Education, Industrial and Exploratory Geophysical Prospecting, of the Russian Soviet Federated Socialist Republic, no. 31, p. 1-9.

McDonald, W. J., and Palmatier, E. D., 1969, Predicting nuclear log response: Journal of Petroleum Technology, v. 21, no. 11 , p. 1421-1426.

Nelson, P. H., Rachiele, R., and Smith, A., 1980, The effect of radon transport in groundwater upon gamma-ray borehole logs: Swedish Nuclear Fuel Supply Company and Lawrence Berkeley Laboratory, issued by the U.S. Department of Commerce, National Technical Information Service, Report LBL-11180, 117 p.
Norris, S. E., 1972, The use of gamma logs in determining the character of unconsolidated sediments and well construction features: Groundwater, v. 10, no. 6, p. 14-21.

Pirson, S. J., Alparone, N., and Avadisian, A., 1966, Implications of $\log$ derived radioactivity anomalies associated with oil and gas fields: Society of Professional Well Log Analysts Annual Logging Symposium, 7th, Tulsa, Okla., 1966, Transactions, p. V1-V25.

Rabe, C. L., 1958, A relation between gamma radiation and permeability, Denver-Julesburg Basin [Neb.]: American Institute of Mining, Metallurgical, and Petroleum Engineers Transactions, 1957, v. 210, p. 358-360.

Sano, S. I., and Kanaya, H., 1966, Observation of partial shrinkage of strata, in Radioisotope instruments in industry and geophysics: International Atomic Energy Agency, Symposium, Warsaw, Poland, 1965, Proceedings, v. 2, p. 279-291.

Scott, J. H., 1963, Computer analysis of gamma-ray logs: Geophysics, v. 28 , no. 3 , p. $457-465$.

Scott, J. H., and others, 1961, Quantitative interpretation of gamma-ray logs: Geophysics, v. 26, no. 2, p. 182-191.

Sippel, R. F., and Hodges, H. D., 1958, LPG-storage well logging: Petroleum Engineer, v. 30, no. 4, p. B118-B123.

Skibitzke, H. E., 1954, The gamma ray logging method in groundwater hydrology: Geological Society of America Regional Meeting, Los Angeles, Calif., 1954, Proceedings, p. $1-4$.

Zorski, Tomasz, 1980, Application of discrete Fourier transform in solving the inverse problem in gamma-ray logging: Acta Geophysica Polonica, v. 28, no. 1, p. 57-66, and Tulsa, Okla., University of Tulsa, Petroleum Abstract no. 238,751 .

\section{CAMMA-CAMMA}

Alger, R. P., and others, 1962, Formation density log applications in liquid-filled holes: Society of Petroleum Engineers of the American Institute of Mining, Metallurgical, and Petroleum Engineers Paper SPE 435, 19 p.

Andrassy, Laszlo, 1980, Approximate graphical and numerical determination of densities corrected for borehole diameter: Geofizikai Kozlemenyek, no. 26, p. 79-88, issued by the University of Tulsa, Petroleum Abstract no. 313,586.

Atal, B. S., Rai, Lajpat, and Bhatnagar, A. S., 1970, Density logging in boreholes using gamma-backscatter technique: National Symposium on Radiation Physies, Bombay, India, 1970, Proceedings, issued by the U.S. Department of Commerce, National Technical Information Service, Report CONF-701138, p. 623-629.

Baker, P. E., 1958, Density logging with gamma rays: American Institute of Mining, Metallurgical, and Petroleum Engineers Transactions, 1957, v. 210, p. 289-294.

Baldwin, W. F., and others, 1966, Slim hole logging in Colorado oil shale: Society of Professional Well Log Analysts Annual Logging Symposium, 7th, Tulsa, Okla., 1966, Transactions, p. C1-C17.

Bishop, J. M., 1970, Utilization of density logs to delineate desaturated zones and estimate porosity in cased holes: Society of Petroleum Engineers of the American Institute of Mining, Metallurgical, and Petroleum Engineers Paper SPE 3185, 12 p. 
Bunker, C. M., and Bradley, W. A., 1961, Measurement of bulk density of drill core by gamma-ray absorption, in Short papers in the geologic and hydrologic sciences: U.S. Geological Survey Professional Paper 424-B, p. B310-313.

Campbell, J. L. P., and Wilson, J. C., 1958, Density logging in the Gulf Coast area: Journal of Petroleum Technology, v. 10, no. 7, p. 21-25.

Chudy, Stephen, 1981, Photon log: Society of Professional Well Log Analysts Annual Logging Symposium, 22d, Mexico City, Mexico, 1981, Transactions, p. GG1-GG15.

Corey, J. C., and Hayes, D. W., 1970, Determination of density and water content of marine sediment in an unextruded core using fast neutron and gamma ray attenuation: Deep-Sea Research, v. 17, no. 5, p. 917-922.

Courtois, Guy, and others, 1963, Gamma sonde finds interface in propane storage reservoir: Nucleonics, v. 21 , no. 1 , p. $76,78$.

Czubek, J. A., 1966, Application du principe de similitude a la mesure gamma-gamma de densite [Application of the similitude principle to gamma-gamma density measurements] (French): Paris, Villeme, France, Secretariat General du Gouvernement, Documentation Francaise, Direction de la Documentation, Report CEA-R 3099, 32 p.

1966, Physical possibilities of gamma-gamma logging, in International Atomic Energy Agency Symposium on Radioisotope Instruments in Industry and Geophysics: Warsaw, Poland, 1965, Proceedings, v. 2, p. 249-275.

Davidson, J. M., Biggar, J. W., and Nielsen, D. R., 1963, Gamma-radiation attenuation for measuring bulk density and transient water flow in porous materials: Journal of Geophysical Research, v. 68 , no. 16, p. $4777-4783$.

Diad'kin, I. G., 1955, On the theory of gamma-gamma logging of drill holes: Izvestia Akademii Nauk SSSR Seriia Geofizicheskaia, v. 1, no. 4, p. 323-331, issued by the U.S. Department of Commerce, National Technical Information Service, Report TT 65-64385, 16 p.

Dodd, P. H., and Droullard, R. F., 1966, A logging system and computer programme to determine rock density of uranium deposits in International Atomic Energy Agency Symposium on Radioisotope Instruments in Industry and Geophysics: Warsaw, Poland, 1965, Proceedings, v. 2, p. 205-224.

Edwards, J. M., 1959, Quantitative evaluation of the density $\log$ in the Rocky Mountain area: Journal of Petroleum Technology, v. 11, no. 12, p. 29-34.

Evans, H. B., 1965, GRAPE-A device for continuous determination of material density and porosity: Society of Professional Well Log Analysts Annual Logging Symposium, 6th, Dallas, Tex., 1965, Transactions, p. B1-B25.

Felder, Benjamin, and Boyeldieu, Claude, 1979, The lithodensity log: Society of Professional Well Log Analysts European Symposium, 6th, London, England, 1979, Transactions, p. 01-020.

Fishel, K. W., and Mayer, Robert, Jr., 1978, Extremely high resolution density coal logging techniques: International Coal Exploration Symposium, 2d, Denver, Colo., 1978, p. 1-17.

Gardner, J. S., and Dumanoir, J. L., 1980, Litho-density log interpretation: Society of Professional Well Log Analysts Annual Logging Symposium, 21st, Lafayette, La., 1980, Transactions, p. N1-N23.
Gardner, R. P., and Roberts, K. F., 1967, Gamma ray gauges for measuring soil density, in Density and moisture content measurements by nuclear methods-National Cooperative Highway Research Program Report 43, part 1: Washington, D. C., National Academy of Sciences, p. 1-19.

Gardner, W. H., Campbell, G. S., and Calissendorff, C., 1972, Systematic and random errors in dual gamma energy soil bulk density and water content measurements: Soil Science Society of America Journal, v. 36, no. 3, p. 393-398.

Head, M. P., and Barnett, M. E., 1980, Digital log calibration-The compensated density log: Society of Petroleum Engineers of the American Institute of Mining, Metallurgical, and Petroleum Engineers Paper SPE 9343, 11 p.

Hearst, J. R., 1976, Effects of mudcake and sonde angle on a simple two-detector density sonde: Log Analyst, v. 17, no. 3, p. 11-15.

Hearst, J. R., and Carlson, R. C., 1969, The RIDS-A density logger for rough holes: Geophysics, v. 34, no. 2, p. 222 234.

Herkelrath, W. N., and Miller, E. E., 1976, High performance gamma system for soil columns: Soil Science Society of America Journal, v. 40, no. 2, p. 331-332.

Hicks, Bill, 1975, Special logging techniques of underground storage and solution mining wells: Northern Ohio Geological Society Symposium on Salt, 4th, Houston, Tex., 1975, Proceedings, v. 2, p. 227-230.

Hirakawa, Seiichi, Fujinaga, Yoshinobu, and Ohkuma, Hiroshi, 1971, Simulation of gamma-ray multiple scattering in rocks: Bulletin of the Japanese Petroleum Institute, v. 13 , no. 2 , p. $267-272$.

Jenkins, R. E., 1963, Gamma-gamma density log: Dallas, Tex., Core Laboratories, Inc., Technical Memorandum 19, 7 p.

Lara, J. M., 1968, Gamma probe calibration tests: Denver, Colo., U.S. Bureau of Reclamation, $18 \mathrm{p}$.

Maus, L. D., 1974, In-situ sediment composition measurement using scattered gamma radiation [University of Rhode Island $\mathrm{Ph}$. D. dissertation]: University Microfilms, International, Publication 74-24,692, 208 p.

Pickell, J. J., and Heacock, J. G., Jr., 1960, Density logging: Geophysics, v. 25, no. 4, p. 891-904.

Preiss, Kenneth, 1968, In situ measurement of marine sediment density by gamma radiation: Deep-Sea Research, v. 15 , no. 5 , p. $637-641$.

1968, Non-destructive laboratory measurement of marine sediment density in a core barrel using gamma radiation: Deep-Sea Research, v. 15, no. 3, p. 401-407.

1970, Relation between energy and error due to nuclear statistics for density measurement by gamma ray transmission: Soil Science, v. 110, no. 3, p. 151-156.

Preiss, Kenneth, and Lahat, A., 1970, A gamma ray density probe designed for foundation exploration in loess development: Beer-Sheva, Israel, Negev Institute of Arid Zone Research, Division of Engineering Sciences Departmental Report 105, 42 p.

Preiss, Kenneth, and Livmat, R., 1972, Note on the behaviour of backscattered gamma ray photons in the scattering medium: Beer-Sheva, Israel, Negev Institute of Arid Zone Research, Division of Engineering Sciences Departmental Report 120, 24 p. 
Preiss, Kenneth, and Supe, C., 1970, Measurement of density of asphalt layers by backscattering of Am-241 gamma radiation: Beer-Sheva, Israel, Negev Institute for Arid Zone Research, Division of Engineering Sciences Departmental Report 107, 38 p.

Robbins, S. L., 1979, Density determinations from borehole gravity data from a shallow lignite zone within the Denver Formation near Watkins, Colorado: Society of Professional Well Log Analysts Annual Logging Symposium, 20th, Tulsa, Okla., 1979, Transactions, p. JJ1-JJ20.

Rodermund, C. G., Alger, R. P., and Tittman, Jay, 1961, Logging empty holes: Society of Professional Well Log Analysts Annual Logging Symposium, 2d, Dallas, Tex., 1961, Transactions, p. $1-4$.

Roney, J. R., 1973, Gamma scattering in marine sediments [University of Rhode Island, Ph. D. dissertation]: University Microfilms, International, Publication 73-31,020, 201 p.

Samworth, J. R., 1974, The radiation density log applied to the resolution of thin beds in coal measures: Society of Professional Well Log Analysts European Symposium, 3d, London, England, 1974, Transactions, p. R1-R12.

Samworth, R. J., 1979, Slimline dual detector density logging-A semi-theoretical approach to correction and compensation: Society of Petroleum Engineers of the American Institute of Mining, Metallurgical, and Petroleum Engineers Paper SPE 8365, 8 p.

Schmoker, J. W., 1981, Organic-matter content of Appalachian Devonian shales determined by use of wire-line logsSummary of work done 1976-80: U.S. Geological Survey Open-File Report 81-181, 32 p.

Scott, J. H., 1977, Borehole compensation algorithms for a small-diameter, dual-detector, density well-logging probe: Society of Professional Well Log Analysts Annual Logging Symposium, 18th, Houston, Tex., 1977, Transactions, p. S1-S17.

Smith, J. W., Thomas, H. E., and Trudell, L. G., 1968, Geologic factors affecting density logs in oil shale: Society of Professional Well Log Analysts Annual Logging Symposium, 9th, New Orleans, La., 1968, Transactions, p. P1P17.

Smith, W. D. M., 1969, Log density, porosity: Oilweek, v. 20 , no. 44 , p. 24-25, 28-29.

Society of Professional Well Log Analysts, Houston Chapter, 1967, Gamma-gamma density logging: Log Analyst, v. 8, no. 3 , p. 31-36.

Taylor, Denis, and Kansara, Mohan, 1966, Measuring density with the nuclear back-scatter method: Nucleonics, v. 24, no. 6 , p. 54-56.

Tittman, Jay, and Wahl, J. S., 1962, Formation density logging gamma-gamma principles and practice: Nuclear Geophysicists Conference, Cracow, Poland, 1962, Proceedings, p. 339-391.

1965, The physical foundations of formation density logging (gamma-gamma): Geophysics, v. 30 , no. 2 , p. 284 293.

Utkin, V. I., and Burdin, Yu.B., 1975, Accuracy of analog registration in gamma-gamma logging: Akademiya Nauk SSSR, Ural Nauchno Tsentr, Sverdlosk, USSR, p. 52-57, issued by the U.S. Department of Commerce, National Technical Information Service, Report UCRL-TRANS$11329,8 \mathrm{p}$.
Varvarin, G. B., Kuznetsov, G. A., and Filippov, E. M., 1966, Investigations into eliminating the effect on the gammagamma log of zones adjacent to the tool: Akademii Nauk SSSR, Seriya, Geologiya 1 Geofizika, v. 6, p. 106-114.

Wahl, J. S., and others, 1964, The dual spacing formation density log: Society of Petroleum Engineers of the American Institute of Mining, Metallurgical, and Petroleum Engineers Paper SPE 989, 8 p.

\section{CAMMA SPECTRAL}

Adams, J. A. S., 1964, Laboratory gamma-ray spectrometer for geochemical studies, in Adams, J. A. S., and Lowder, W. M., eds., The natural radiation environment: Chicago, University of Chicago Press, p. 485-497.

Adams, J. A. S., and Fryer, G. E., 1964, Portable gamma-ray spectrometer for field determination of thorium, uranium, and potassium, in Adams, J. A. S., and Lowder, W. M., eds., The natural radiation environment: Chicago, University of Chicago Press, p. 577-596.

Adams, J. A. S., and Lowder, W. M., 1964, Properties of the uranium and thorium series, in Adams, J. A. S., and Lowder, W. M., eds., The natural radiation environment: Chicago, University of Chicago Press, p. 1033-1036.

Baranov, V. I., and Khristianova, L. A., 1966, Radioactivity of ocean deposits, in Chemistry of the earth's crust: U.S.S.R., Academy of the Sciences, v. 1, p. 425-432.

Bowman, W. W., 1978, Development of a borehole probe detector for measurement of radionuclide transport in ground water, in Savannah River Laboratory environmental transport and effects research, annual report: U.S. Department of Commerce, National Technical Information Service, Report DP-1526, p. 111-112.

Boynton, G. R., 1975, Canister cryogenic system for cooling germanium semiconductor detectors in borehole and marine probes: Nuclear Instruments and Methods in Physics Research, v. 123, no. 3, p. 599-603.

Brannon, H. R., Jr., and Osoba, J. S., 1956, Spectral gammaray logging [Texas]: Journal of Petroleum Technology, v. 8 , no. 2 , p. $30-35$.

Bristow, Quentin, 1977, A system for the offline processing of borehole gamma-ray spectrometry data on a nova minicomputer, in Report of activities, part A: Geological Survey of Canada Paper 77-1A, p. 87-89.

Brodzinski, R. L., 1981, In situ subterranean determination of actinides by high resolution gamma-ray spectrometry: International Atomic Energy Agency, issued by the U.S. Department of Commerce, National Technical Information Service, Report PNL-SA-8992, 14 p.

Brodzinski, R. L., and Nielson, H. L., 1980, A well logging technique for the in situ determination of ${ }^{90} \mathrm{Sr}$ : Nuclear Instruments and Methods of Physics Research 173, p. 299-301.

Bunker, C. M., and Bush, C. A., 1981, Radioelement distribution in a 3.06-kilometer drill hole in Precambrian crystalline rocks, Wind River Mountains, Wyoming, in Shorter contributions to isotope research in the Western United States, 1980: U.S. Geological Survey Professional Paper 1199-A-E, p. 7-14.

Caldwell, R. L., and others, 1963, Gamma-ray spectroscopy in well logging: Geophysics, v. 28, no. 4, p. 617-632. 
Christell, Roland, Ljunggren, K., and Landstrom, Ove, 1976, Brief review of developments in nuclear geophysics in Sweden: Nuclear Geophysics in Sweden, p. 21-45.

Close, D. A., Evans, M. L., and Jain, Mahavir, 1980, Gammaray spectral calculations for uranium borehole logging: Los Alamos Scientific Laboratory, issued by the U.S. Department of Commerce, National Technical Information Service, Report LA-8417-MS, 60 p.

Conaway, J. G., and Bristow, Quentin, 1981, Pitfalls in quantitative gamma ray logging-Calibration sleeves and ${ }^{241} \mathrm{Am}$ temperature stabilization: Society of Professional Well Log Analysts Annual Logging Symposium, 22d, Mexico City, Mexico, 1981, Transactions, p. X1-X10.

Conaway, J. G., and Killeen, P. G., 1980, Gamma-ray spectral logging for uranium: Canadian Mining and Metallurgical Bulletin, v. 73 , no. 813 , p. $115-123$.

Doig, Ronald, 1968, The natural gamma-ray flex-In-situ analysis: Geophysics, v. 33, no. 2, p. 311-328.

Duffey, D., El-Kady, A., and Senftle, F. E., 1970, Analytical sensitivities and energies of thermal-neutron-capture gamma rays: Nuclear Instruments and Methods of Physics Research, v. 80, no. 1 , p. 149-171.

Ebert, P. J., and Lauzon, A. F., 1966, Measurement of gamma ray induced secondary electron current from various elements: Transactions of the Institute of Electrical and Electronics Engineers, Nuclear Science Series, v. 13, p. 735741.

Eldridge, J. S., and Oakes, T. W., 1978, Gamma-ray determinations with a portable analyzer: Oak Ridge National Laboratory, issued by the U.S. Department of Commerce, National Technical Information Service, Report CONF$780110-6,8$ p.

Evans, H. B., and others, 1979, A borehole gamma ray spectrometer for uranium exploration: Society of Professional Well Log Analysts Annual Logging Symposium, 20th, Tulsa, Okla., 1979, Transactions, p. X1-X33.

Evans, M. L., 1981, A computer model for calculating gammaray pulse-height spectra for logging applications: Los Alamos Scientific Laboratory, issued by the U.S. Department of Commerce, National Technical Information Service, Report CONF-810228-1, 13 p.

Fertl, W. H., 1979, Gamma ray spectral data assists in complex formation evaluation: Log Analyst, v. 20, no. 5, p. 3-37.

Fertl, W. H., and Rieke, H. H., III, 1979, Gamma ray spectral evaluation techniques identify fractured shale reservoirs and source rock characteristics: Society of Petroleum Engineers, of the American Institute of Mining, Metallurgical, and Petroleum Engineers Paper SPE 8454, 14 p.

Fertl, W. H., Welker, D. W., and Hopkinson, E. C., 1978, The Dresser Atlas spectralog-A look at basic principles, field applications and interpretive concepts of gamma ray spectral logging: Soviet-American Formation Evaluation Symposium, Ufa, Bashkiria, U.S.S.R., 1978, Technical paper, $40 \mathrm{p}$.

George, D. D., and others, 1978, A borehole gamma-ray spectrometer for uranium exploration: U.S. Department of Energy, issued by the U.S. Department of Commerce, National Technical Information Service, Report GJBX82(78), 53 p.
Gilchrist, W. A., Jr., and others, 1982, Application of gamma ray spectroscopy to formation evaluation: Society of Professional Well Log Analysts Annual Logging Symposium, 23d, Corpus Christi, Tex., 1982, Transactions, p. B1-B28.

Goldman, L. H., and Marr, H. E., 1979, Applications of high resolution gamma ray spectroscopy to well logging: Society of Professional Well Log Analysts Annual Logging Symposium, 20th, Tulsa, Okla., 1979, Transactions, 8 p.

Grasty, R. L., 1979, Gamma ray spectrometric methods in uranium exploration-Theory and operational procedures in Geophysics and geochemistry in the search for metallic ores: Geological Survey of Canada Economic Geology Report 31, p. 147-161.

Grasty, R. L., and Darnley, A. G., 1971, The calibration of gamma-ray spectrometers for ground and airborne use: Geological Survey of Canada Paper 71-17, p. 1-27.

Heath, R. L., 1964, Scintillation spectrometry gamma-ray spectrum catalogue (2d ed., v. 2): U.S. Atomic Energy Commission, issued by the U.S. Department of Commerce, National Technical Information Service, Report IDO-16880-2, $287 \mathrm{p}$.

Heath, R. L., and others, 1965, The calculation of gamma-ray shapes for sodium iodide scintillation spectrometersComputer programs and experimental problems: U.S. Atomic Energy Commission, issued by the U.S. Department of Commerce, National Technical Information Service, Report IDO-17017, 158 p.

Heflin, J. D., and Nettleton, K. A., 1980, Formation evaluation utilizing gamma ray spectral analysis: Society of $\mathrm{Pe}-$ troleum Engineers of the American Institute of Mining, Metallurgical, and Petroleum Engineers Paper SPE 9042, $7 \mathrm{p}$.

Keys, W. S., Senftle, F. E., and Tanner, A. B., 1979, Use of $\mathrm{NaI}(\mathrm{Tl})$ and germanium detectors for in situ gamma-ray spectral monitoring of boreholes at nuclear waste-disposal sites: U.S. Geological Survey Open-File Report 79-1220, $23 \mathrm{p}$.

Killeen, P. G., 1979, Gamma ray spectrometric methods in uranium exploration-Application and interpretation, in Geophysics and geochemistry in the search for metallic ores: Geological Survey of Canada Economic Geology Report 31, p. 163-229.

Killeen, P. G., and Carmichael, C. M., 1970, Gamma-ray spectrometer calibration for field analysis of thorium, uranium and potassium: Canadian Journal of Earth Sciences, v. 7, no. 4, p. 1093-1098.

Lock, G. A., and Hoyer, W. A., 1971, Natural gamma-ray spectral logging [abs.]: Society of Professional Well Log Analysts Annual Logging Symposium, 12th, Dallas, Tex., 1971, Transactions, p. AA1.

Lovborg, Lief, 1967, A portable $\gamma$-spectrometer for field use: Danish Atomic Energy Commission, Research Establishment Riso Report no. 168, 36 p.

Lovborg, Leif, and others, 1972, Drill-core scanning for radioelements by gamma-ray spectrometry: Geophysics, v. 37, no. 4, p. $675-693$.

Mahdavi, Azizeh, 1964, The thorium, uranium, and potassium contents of Atlantic and Gulf Coast beach sands, in Adams, J. A. S., and Lowder, W. M., eds., The natural radiation environment: Chicago, University of Chicago Press, p. 87-114. 
Mathews, M. A., Koizumi, C. J., and Evans, H. B., 1978, DOE-Grand Junction logging model data synopsis: U.S. Department of Energy, issued by the U.S. Department of Commerce, National Technical Information Service, Report GJBX-76(78), 52 p.

Moll, S. H., 1980, Spectral gamma logging in the Copper Mountain Uranium District-A case study in fractured quartz monzonite: Society of Professional Well Log Analysts Annual Logging Symposium, 21st, Lafayette, La., 1980, Transactions, p. 01-019.

Moxham, R. M., and Tanner, A. B., 1977, High-resolution gamma-ray spectrometry in uranium exploration: U.S. Geological Survey Journal of Research, v. 5, no. 6, p. 783795.

Nielson, H. L., Wogman, N. A., and Brodzinski, R. L., 1977, In situ subterranean gamma-ray spectroscopy: Nuclear Instruments and Methods of Physics Research, v. 143, p. 385-389.

Nix, D. W., Powers, R. P., and Kanipe, L. G., 1979, Application of germanium detectors to environmental monitoring: Tennessee Valley Authority, issued by the U.S. Department of Commerce, National Technical Information Service, Report EPA-600/7-79-054, 123 p.

Quirein, J. A., Gardner, J. S., and Watson, J. T., 1982, Combined natural gamma ray spectrallith-density measurements applied to complex lithologies: Society of Petroleum Engineers of the American Institute of Mining, Metallurgical, and Petroleum Engineers Paper SPE 11143, 14 p.

Rhodes, D. F., and Mott, W. E., 1966, Quantitative interpretation of gamma-ray spectral logs: Geophysics, v. 31, no. 2, p. 410-418.

Schenewerk, P. A., and others, 1980, Natural gamma-ray spectral logging aids_-Granite Wash Reservoir evaluation: Society of Professional Well Log Analysts Annual Logging Symposium, 21st, Lafayette, La., 1980, Transactions, p. BB1-BB23.

Schimschal, Ulrich, 1980, Quantitative effects of lithology, borehole environment, and probe design in gamma spectral logging with scintillation crystals: Log Analyst, v. 21, no. 5, p. 3-10.

1980, Scintillation detectors in gamma spectral logging-Geometry, absorption, and calibration: U.S. Geological Survey Open-File Report 80-688, 33 p.

1981, Mathematical model of gamma-ray spectrometry borehole logging for quantitative analysis: U.S. Geological Survey Open-File Report 81-402, 26 p.

Senftle, F. E., 1980, Application of gamma-ray spectral analysis to subsurface mineral exploration, in Muelke, G. K., ed., Short course in neutron activiation analysis in the geosciences: Mineralogical Association of Canada Short Course Handbook, v. 5, chap. 8, p. 211-254.

Serra, Oberto, Baldwin, J. L., and Quirein, J. A., 1980, Theory interpretation and practical applications of natural gamma ray spectroscopy: Society of Professional Well Log Analysts Annual Logging Symposium, 21st, Lafayette, La., 1980, Transactions, p. Q1-130.

Stromswold, D. C., and Kosanke, K. L., 1978, Calibration and error analysis for spectral radiation detectors: Transactions of the Institute of Electrical and Electronics Engineers, Nuclear Science Series, v. NS-25, no. 1, p. 782786.
1979, Spectral gamma-ray logging, I-Energy stabilization methods: Society of Professional Well Log Analysts Annual Logging Symposium, 20th, Tulsa, Okla., 1979, Transactions, p. DD1-DD20.

Stromswold, D. C., and Wilson, R. D., 1981, Calibration and data correction techniques for spectral gamma-ray logging: Society of Professional Well Log Analysts Annual Logging Symposium, 22d, Mexico City, Mexico, 1981,Transactions, p. M1-M18.

Stuart, T. P., 1977, Limiting values for radionuclide concentration in the soil from remote spectrometer measurements: U.S. Department of Commerce, National Technical Information Service, Report EGG-1183-1716, 31 p.

Tanner, A. B., Moxham, R. M., and Senftle, F. E., 1977, Assay for uranium and determination of disequilibrium by means of in situ high-resolution gamma-ray spectrometry: U.S. Geological Survey Open-File Report 77-571, 22 p.

West, F. G., and Laughlin, A. W., 1976, Spectral gamma logging in crystalline basement rocks: Geology, v. 4, p. 617618.

West, Leon, Umbarger, C. J., and Dempsey, Thomas, 1978, A germanium detector system for the detection of transuranics at low-activity concentrations in soil: Los Alamos Scientific Laboratory, issued by the U.S. Department of Commerce, National Technical Information Service, Report CONF-780110-10, $12 \mathrm{p}$.

Westaway, Peter, Hertzog, R. C., and Plasek, R. E., 1980, The gamma spectrometer tool inelastic and capture gamma-ray spectroscopy for reservoir analysis: Society of Petroleum Engineers of the American Institute of Mining, Metallurgical, and Petroleum Engineers Paper SPE 9461, $16 \mathrm{p}$.

Wichmann, P. A., McWhirter, V. C., and Hopkinson, E. C., 1975, Field results of the natural gamma ray spectralog: Canadian Well Logging Society Formation Evaluation Symposium, 5th, Calgary, Alberta, 1975, Transactions, p. S1-S12.

Wiley, Ralph, and Zittel, R. J., 1982, Natural gamma ray data of various sandstones: Society of Professional Well Log Analysts Annual Logging Symposium, 23d, Corpus Christi, Tex., 1982, Transactions, p. K1-K20.

Wilson, R. D., and others, 1979, Spectral gamma-ray logging, II-Borehole correction factors: Society of Professional Well Log Analysts Annual Logging Symposium, 20th, Tulsa, Okla., 1979, Transactions, p. EE1-EE16.

Wilson, R. D., and others, 1979, Spectral gamma-ray logging, III-Thin bed and formation effects: Society of Professional Well Log Analysts Annual Logging Symposium, 20th, Tulsa, Okla., 1979, Transactions, p. FF1-FF17.

Wilson, R. D., and Stromswold, D. C., 1981, Spectral gammaray logging studies: Bendix Field Engineering Corporation, issued by the U.S. Department of Commerce, National Technical Information Service, Report GJBX21(81), $187 \mathrm{p}$.

Wollenberg, H. A., and Smith, A. R., 1964, Studies in terrestrial gamma radiation in Adams, J. A. S., and Lowder, W. M., eds., The natural radiation environment: Chicago, University of Chicago Press, p. 513-566.

Youngblood, W. E., 1981, The application of natural gamma ray spectrometry $\log$ as an aid in $\log$ evaluation in Saudi Arabia: Society of Petroleum Engineers of the American Institute of Mining, Metallurgical, and Petroleum Engineers Paper SPE 9615, 11 p. 


\section{GEOPRESSURE}

Chiarelli, Andre, 1975, Use compaction profiles to predict abnormal pressures: World Oil, v. 180, no. 6, p. 101-110.

Fertl, W. H., and Timko, D. J., 1970, Association of salinity variations and geopressures in soft and hard rock: Society of Professional Well Log Analysts Annual Logging Symposium, 11th, Los Angeles, Calif., 1970, Transactions, p. J1-J23.

Hottmann, C. E., and Johnson, R. K., 1965, Estimation of formation pressures from log-derived shale properties: Journal of Petroleum Technology, v. 17, no. 6, p. 717-722.

Jones, P. H., 1978, Geopressured-geothermal test of the EDNA Delcamre no. 1 well, Tigre Lagoon field, Vermilion Parish, Louisiana-Geology of the Tigre Lagoon Field, Planulina Basin: U.S. Department of Energy, issued by the U.S. Department of Commerce, National Technical Information Service, Report ORO-4937-T2, $49 \mathrm{p}$.

Lane, R. A., and Macpherson, L. A., 1974, A review of geopressure evaluation from well logs-Louisiana Gulf Coast: Society of Petroleum Engineers of the American Institute of Mining, Metallurgical, and Petroleum Engineers, Paper SPE 5033, 16 p.

Ritch, H. J., and Kozik, H. G., 1971, Petrophysical study of overpressured sandstone reservoirs, Vicksburg Formation, McAllen Ranch Field, Hidalgo County, Texas: Society of Professional Well Log Analysts Annual Logging Symposium, 12th, Dallas, Tex., 1971, Transactions, p. BB1-BB14.

\section{CEOTHERMAL}

Aamodt, R. L., and Riecker, R. E., 1980, Basic research needed for the development of geothermal energy: Los Alamos Scientific Laboratory, issued by the U.S. Department of Commerce, National Technical Information Service, Report LA-8562-MS, 19 p.

Adorni, N., and others, 1980, Construction of a probe for measuring temperature and pressure in deep wells: Geothermics, v. 9 , no. 3/4, p. 251-259.

Archuleta, J. R., 1977, Downhole geothermal sondes: Geothermal Resources Council Transactions, v. 1, p. 7-8.

Archuleta, J. R., and Todd, B. E., 1978, Hot dry rock geothermal energy development project cable-head assembly: Los Alamos Scientific Laboratory, issued by the U.S. Department of Commerce, National Technical Information Service, Report LA-7325-MS, 8 p.

Baker, L. E., Campbell, A. B., and Hughen, R. L., 1975, Well-logging technology and geothermal applications-A survey and assessment with recommendations: Sandia National Laboratory Energy Report SAND 75-0275, 75 p.

Ball, L. W., 1977, Developments in geothermal logging technology: Geothermal Resources Council Transactions, v. 2, p. 11.

Cochran, L. E., 1979, Formation evaluation in the geothermal environment, the Geysers steam field, California: Society of Petroleum Engineers of the American Institute of Mining, Metallurgical, and Petroleum Engineers Paper SPE 8452,12 p.

Davis, D. G., and Sanyal, S. K., 1979, Case history report on East Mesa and Cerro Prieto geothermal field: Los Alamos Scientific Laboratory, issued by the U.S. Department of Commerce, National Technical Information Service, Report LA-7889-MS, 181 p.
Dennis, B. R., 1980, Borehole survey instrumentation development for geothermal applications: Society of Professional Well Log Analysts Annual Logging Symposium, 21st, Lafayette, La., 1980, Transactions, p. D1-D16.

Ehring, T. W., and others, 1978, Formation evaluation concepts for geothermal resources: Society of Professional Well Log Analysts Annual Logging Symposium, 19th, El Paso, Tex., 1978, Transactions, p. FF1-FF14.

Elliott, D. G., 1977, Comparison between theoretical and experimental well flow and analysis of self-flowing versus pumping: Geothermal Resources Council Transactions, v. 1 , p. 89-90.

Enniss, D. 0., and others, 1978, Capabilities to determine rock properties at simulated geothermal conditions: American Society of Mechanical Engineers Energy Technology Conference, Houston, Tex., 1978, Proceedings, p. 1-8.

Ershaghi, Iraj, Dougherty, E. E., and Handy, L. L., 1981, Formation evaluation in liquid dominated geothermal reservoir: U.S. Department of Energy, issued by the U.S. Department of Commerce, National Technical Information Service, Report DOE/ET/28384-T1, 104 p.

Ershaghi, Iraj, Ghaemian, Shahed, and Abdassah, Doddy, 1981, Lithology and hydrothermal alteration determination from well logs for the Cerro Prieto wells: Los Alamos National Laboratory, issued by the U.S. Department of Commerce, National Technical Information Service, Report LA-9075-MS, 28 p.

Ershaghi, Iraj, and others, 1979, Application of oilfield well $\log$ interpretation techniques to the Cerro Prieto geothermal field: Society of Professional Well Log Analysts Annual Logging Symposium, 20th, Tulsa, Okla., 1979, Transactions, p. PP1-PP11.

Fertl, W. H., 1980, Geophysical well logs applied to geothermal resource evaluation: Revue de L'Institute Francais du Petrole, v. 35, no. 3, p. 461-468.

Fuchs, R. L., and Huttrer, G. W., 1975, Geothermal energySlow growing industry finally heats up, part 1: Engineering and Mining Journal, v. 176, no. 1, p. 89-93.

1975, Geothermal. energy-The challenges that lie ahead, part 2: Engineering and Mining Journal, v. 176, no. 2 , p. 87-82.

Glenn, W. E., Hulen, J. B., and Nielson, D. L., 1981, A comprehensive study of LASL well C/T-2, Roosevelt Hot Springs KGRA, Utah, and applications to geothermal well logging: Los Alamos Scientific Laboratory, issued by the U.S. Department of Commerce, National Technical Information Service, Report LA-8686-MS, 175 p.

Glenn, W. E., Ross, H. P., and Atwood, J. W. 1980, Review of well logging in the Basin and Range known geothermal resource areas: Society of Petroleum Engineers of the American Institute Mining, Metallurgical, and Petroleum Engineers Paper SPE 9496, 17 p.

Goss, Ronald, Comb, Jim, and Timur, Aytekin, 1975, Prediction of thermal conductivity in rocks from other physical parameters and from standard geophysical well logs: Society of Professional Well Log Analysts Annual Logging Symposium, 16th, New Orleans, La., 1975, Transactions, p. MM1-MM21.

Hallenburg, J. K., and others, eds., 1982, Geothermal log interpretation handbook: Tulsa, Okla., Society of Professional Well Log Analysts, 538 p. 
Hannah, J. L., 1975, The potential of low temperature geothermal resources in northern California: California Division of Oil and Gas Report TR13, $53 \mathrm{p}$.

Keys, W. S., 1976, Borehole geophysics in geothermal wellsProblems and progress: Workshop on Geothermal Reservoir Engineering, 2d, Stanford, Calif., 1976, Proceedings, p. 66-74.

1980, Application of the acoustic televiewer to the characterization of hydraulic fractures in geothermal wells: Geothermal Reservoir Well Stimulation Symposium, San Francisco, Calif., 1980, Proceedings, p. 176-202.

1982, Borehole geophysics in geothermal exploration, in Fitch, A. A., ed., Developments in geophysical exploration methods -3: London, England, Elsevier Applied Science Publishers, p. 195-238.

Keys, W. S., and Sullivan, J. K., 1979, Role of borehole geophysics in defining the physical characteristics of the Raft River geothermal reservoir, Idaho: Geophysics, v. 64 , no. 6, p. 1116-1141.

Kratz, H. R., Day, E. A., and Ginn, W. G., 1979, Improved geothermal well logging tools using no downhole electronics: Systems Science and Software, issued by the U.S. Department of Commerce, National Technical Information Service, Report SSS-R-79-3947, 51 p.

Lamers, M. D., 1979, Measurement requirements and methods for geothermal reservoir system parameters (an appraisal): Lawrence Berkeley Laboratory, issued by the U.S. Department of Commerce, National Technical Information Service, Report LBL-9090, $42 \mathrm{p}$.

Lyons, D. J., and van de Kamp, P. C., 1980, Subsurface geological and geophysical study of the Cerro Prieto geothermal field Baja California, Mexico: Lawrence Berkeley Laboratory, issued by the U.S. Department of Commerce, National Technical Information Service, Report LBL$10540,95 \mathrm{p}$.

Mathews, M. A., Arney, Barbara, and Sayer, Suzanne, 1979, Log comparison from geothermal calibration/test well C/T: Society of Professional Well Log Analysts Annual Logging Symposium, 20th, Tulsa, Okla., 1979, Transactions, p. RR1-RR25.

McDonald, W. J., Leon, P. A., and Pittard, Gerard, 1981, Evaluation of equipment and methods to map lost circulation zones in geothermal wells: Sandia National Laboratory, issued by the U.S. Department of Commerce, National Technical Information Service, Report SAND80-7057, 208 p.

Meidav, T., and Furgerson, R., 1972, Resistivity studies of the Imperial Valley geothermal area, California: Geothermics, v. 1, no. 2, p. 47-62.

Murphy, H. D., and others, 1976, Preliminary assessment of a geothermal energy reservoir formed by hydraulic fracturing: Society of Petroleum Engineers of the American Institute of Mining, Metallurgical, and Petroleum Engineers Paper SPE 6093, $10 \mathrm{p}$.

Pettitt, R. A., 1975, Testing, drilling and logging of geothermal test hole GT-2, phase III: Los Alamos Scientific Laboratory, issued by the U.S. Department of Commerce, National Technical Information Service, Report LA-5965PR, $13 \mathrm{p}$.

Potter, R. M., 1977, Hydraulic fracture initiation sites in open boreholes identified by geophysical logs: Workshop on Geothermal Reservoir Engineering, 3d, Stanford, Calif., 1977, Proceedings, p. 36-42.
Randall, Walter, 1974, An analysis of the subsurface structure and stratigraphy of the Salton Sea geothermal anomaly, Imperial Valley, California [University of California, $\mathrm{Ph}$. D. dissertation]: University Microfilms, International, Publication 77-14407, 78 p.

Rigby, F. A., 1980, Fracture identification in an igneous geothermal reservoir-Surprise Valley, California: Society of Professional Well Log Analysts Annual Logging Symposium, 21st, Lafayette, La., 1980, Transactions, p. Z1Z9.

1981, Application of geothermal well log data for evaluation of reservoir potential: Los Alamos Scientific Laboratory, issued by the U.S. Department of Commerce, National Technical Information Service, Report LA-8778MS, $69 \mathrm{p}$.

Rigby, F. A., and Reardon, P., 1979, Benefit cost analysis for research in geothermal log interpretation: Los Alamos Scientific Laboratory, issued by the U.S. Department of Commerce, National Technical Information Service, Report LA-7922-MS, 100 p.

Rigby, F. A., and Zebal, G. P., 1981, Case history on geothermal well log interpretation Surprise Valley-California: Los Alamos Scientific Laboratory, issued by the U.S. Department of Commerce, National Technical Information Service, Report LA-8598-MS, 58 p.

Ross, E. W., and others, 1982, Nuclear logging and geothermal $\log$ interpretation-Formation temperature sonde evaluation: Los Alamos Scientific Laboratory, issued by the U.S. Department of Commerce, National Technical Information Service, Report LA-9159-MS, $46 \mathrm{p}$.

Sandquist, G., and others, 1977, Geothermal down hole velocity measurement device: Geothermal Resources Council Transactions, v. 1, p. 275-276.

1977, On evaluating the energy capacity and lifetime of fracture dominated geothermal reservoirs: Intersociety Energy Conversion Engineering Conference, 12th, Washington, D. C., 1977, Proceedings, p. 1-6.

Sanyal, S. K., 197\%, Analysis of geothermal well logs; Workshop on Geothermal Reservoir Engineering, 3d, Stanford, Calif., 1977, Proceedings, p. 81-84.

Sanyal, S. K., Juprasert, Sirisak, and Jubache, Michael, 1979, An evaluation of a rhyolite-basalt-volcanic ash sequence from well logs: Society of Professional Well Log Analysts Annual Logging Symposium, 20th, Tulsa, Okla., 1979, Transactions, p. TT1-TT7.

Sanyal, S. K., Wells, W. E., and Bickham, R. E., 1980, Geothermal well $\log$ interpretation state-of-the art: Los Alamos Scientific Laboratory, issued by the U.S. Department of Commerce, National Technical Information Service, Report LA-8211-MS, 321 p.

Sethi, D. K., and Fertl, W. H., 1980, Geophysical well logging operations and log analysis in geothermal well Desert Peak no. B-23-1: Los Alamos Scientific Laboratory, issued by the U.S. Department of Commerce, National Technical Information Service, Report LA-8254-MS, 69 p.

Stefansson, Valgardur, and Steingrimsson, Benedikt, 1980, Geothermal logging, I-An introduction to techniques and interpretation: National Energy Authority, Reykjavik, Iceland, issued by the U.S. Department of Commerce, National Technical Information Service, Report N81 32698/5, 117 p. 
Stevens, H. H., Jr., Ficke, J. F., and Smoot, G. F., 1975, Water temperature-Influential factors, field measurement, and data presentation: U.S. Geological Survey Techniques of Water-Resources Investigations, Book 1, Chapter D1, 65 p.

Stoker, R. C., Goldman, Dennis, and Kunze, J. F., 1977, Deducing production zones from well logs: Geothermal Resources Council Transactions, v. 1, p. 279-280.

Syms, M. C., and Syms, P. H., 1981, Water flow and temperature logs from wells in the Wairakei and Broadlands geothermal fields: New Zealand Department of Scientific and Industrial Research, Geophysics Division Report no. 183, $84 \mathrm{p}$.

Syms, M. C., Syms, P. H., and Bixley, P. P., 1982, Interpretation of flow measurement in geothermal wells without caliper data: Log Analyst, v. 23, no. 2, p. 34-45.

Takahashi, P. K., and Chen, B. H., 1975, Geothermal reservoir engineering: Geothermal Energy Magazine, v. 3, no. 10 , p. 7-23.

Takahashi, P. K., and others, 1975, State-of-the-art of geothermal reservoir engineering: American Society of Civil Engineers, Journal of the Power Division, Proceedings, v. 101, no. POI, p. 111-126.

West, F. G., and Laughlin, A. W., 1976, Spectral gamma logging in crystalline basement rocks: Geology, v. 4, no. 10, p. $617-618$.

Witherspoon, P. A., and others, 1978, Mexican-American cooperative program at the Cerro Prieto geothermal field: Lawrence Berkeley Laboratory, issued by the U.S. Department of Commerce, National Technical Information Service, Report LBL-7095, 33 p.

Wonn, J. W., 1977, Acoustic sensor development for geothermal borehole televiewer: Pittsburg, Pa., Westinghouse Research and Development Center, 4 p.

\section{GRAVIMETER, BOREHOLE}

Byerley, K. A., and Schmoker, J. W., 1977, Density and porosity estimates from borehole gravity data in Castle Pines No. 3, No. 2, and No. 1 water wells, Douglas County, Colorado: U.S. Geological Survey Open-File Report 77-875, $17 \mathrm{p}$.

Hearst, J. R., and Carlson, R. C., 1982, Measurement and analysis of gravity in boreholes, in Fitch, A. A., ed., Developments in geophysical exploration methods-3: London, England, Elsevier Applied Science Publishers, p. $269-303$.

Hearst, J. R., Kasameyer, P. W., and Owen, L. B., 1978, Potential uses for a high-temperature borehole gravimeter: Lawrence Livermore Laboratory, issued by the U.S. Department of Commerce, National Technical Information Service, Report UCRL $-52421,8 \mathrm{p}$.

Howell, L. G., Heintz, K. O., and Barry, A., 1966, The development and use of a high-precision downhole gravity meter: Geophysics, v. 31, no. 4, p. 764-772.

Jageler, A. H., 1975, Improved hydrocarbon reservoir evaluation through use of borehole gravimeter data: Society of Petroleum Engineers of the American Institute of Mining, Metallurgical, and Petroleum Engineers Paper SPE 5511, $19 \mathrm{p}$.

Jones, B. R., 1972, Downhole gravity tool spots distant porosity: World Oil, v. 175, no. 2, p. 56-59.
Lukavchenko, P. I., 1962, Observations with gravimeters in wells and shafts: Razvedochnaya i Promyslovaya Geofizika, no. 43, p. 52-64.

McCulloh, T. H., 1965, A confirmation by gravity measurements of an underground density profile based on core densities: Geophysies, v. 30, no. 6, p. 1108-1132.

1966, Gravimetric effects of petroleum accumulationsA preliminary summary: U.S. Geological Survey Circular $530,4 \mathrm{p}$.

1966, The promise of precise borehole gravimetry in petroleum exploration and exploitation: U.S. Geological Survey Circular 531, $12 \mathrm{p}$.

Rasmussen, N. F., 1975, Borehole gravimeter finds bypassed oil, gas: Oil and Gas Journal, v. 73, no. 39, p. 100-104.

1977, Gravity logs promise new applications: Petroleum Engineer, v. 49, no. 7, p. 21-24.

Robbins, S. L., 1979, Description of a special logging truck built for the U.S. Geological Survey for borehole gravity surveys: U.S. Geological Survey Open-File Report 79$1511,72 \mathrm{p}$.

Schmoker, J. W., 1977, Density variations in a quartz diorite determined from borehole gravity measurements, San Benito County, California: Log Analyst, v. 18 , no. 2, p. 32 38.

Schmoker, J. W., and others, 1979, Preliminary porosity estimates on south-Florida Cenozoic carbonate rocks based on borehole gravity measurements: U.S. Geological Survey Open-File Report 79-1652, 18 p.

\section{GROUND-WATER APPLICATIONS}

Barraclough, J. T., and others, 1967, Hydrology of the National Reactor Testing Station, Idaho, 1966: U.S. Geological Survey, issued by the U.S. Department of Commerce, National Technical Information Service, Report TID-4500, $95 \mathrm{p}$.

Barraclough, J. T., Teasdale, W. E., and Jensen, R. G., 1967, Hydrology of the National Reactor Testing Station, Idaho-Annual progress report, 1965: U.S. Geological Survey, issued by the U.S. Department of Commerce, National Technical Information Service, Report ID0-22048, $107 \mathrm{p}$.

Bays, C. A., and Folk, S. H., 1942, Geophysical surveys in water wells: The Illinois Well Driller, v. 12, no. 4, p. 7-9.

1944, Geophysical logging of water wells in northeastern Illinois: Journal of Western Society of Engineers, v. 49, no. 3, p. 248-266.

Blankennagel, R. K., 1967, Hydraulic testing techniques of deep drill holes at Pahute Mesa, Nevada Test Site: U.S. Geological Survey open-file report, Special Studies I-1, 50 p.

Davis, R. W., 1967, A geophysical investigation of hydrologic boundaries in the Tueson basin, Pima County, Arizona [University of Arizona Ph. D. dissertation]: University Microfilms International, Publication 67-12,295, 64 p.

Drost, Walter, and others, 1974, Iostope methods in groundwater hydrology: Brussels, Belgium, Eurostop Office Information and Documentation Service Series, Booklet 61, Monograph 16, $176 \mathrm{p}$.

Johnson, A. I., 1964, An outline of equipment useful for hydrologic studies: U.S. Geological Survey open-file report, 24 p. 
Jones, P. H., 1968, Geochemical hydrodynamics-A possible key to the hydrology of certain aquifer systems in the northern part of the Gulf of Mexico: International Geological Congress, 23d, Prague, 1968, Proceedings, v. 17, p. 113-125.

1968, Hydrodynamics of geopressure in the northern Gulf of Mexico basin: Society of Petroleum Engineers of the American Institute of Mining, Metallurgical, and Petroleum Engineers Paper SPE 2207, 12 p.

1970, Hydrology of Quaternary delta deposits of the Mississippi River, in Symposium on the Hydrology of Deltas: Gentbrugge, Belgium, International Association of Scientific Hydrology-UNESCO Publication 90, v. 1, p. 49-63.

Keys, W. S., 1967, The application of radiation logs to groundwater hydrology, in Isotopes in hydrology-A symposium, Vienna, 1966, Proceedings: Vienna, Austria, International Atomic Energy Agency, p. 477-487.

1967, Well logging in ground-water hydrology: Society of Professional Well Log Analysts Annual Logging Symposium, 8th, Denver, Colo., 1967, Transactions, p. K1K21.

Keys, W. S., 1970, Borehole geophysics as applied to groundwater, in Mining and groundwater geophysics, 1967: Geological Survey of Canada Economic Geology Report 26, p. 598-612.

McGuinness, C. L., 1967, Ground-water research in the U.S.A.: Earth Science Reviews, v. 3, no. 3, p. 181-202.

Meyer, W. R., 1962, Use of a neutron moisture probe to determine the storage coefficient of an unconfined aquifer, in Geological Survey Research 1962: U.S. Geological Survey Professional Paper 450-E, p. E174-E176.

Morris, T. S., 1952, Investigating ground water supplies with electric well logs: Water Well Journal, v. 6 , no. 3 , p. 12 , 32, 34, 36.

Nelson, P. H., 1982, Advances in borehole geophysics for hydrology: Geological Society of America Special Paper 189, p. 207-219.

Olmsted, F. H., 1962, Chemical and physical character of ground water in the National Reactor Testing Station, Idaho: U.S. Atomic Energy Commission, issued by the U.S. Department of Commerce, National Technical Information Service, Report IDO-22043-USGS, 81 p.

Schimschal, Ulrich, 1981, The relationship of geophysical measurements to hydraulic conductivity at the Brantley Damsite, New Mexico: Geoexploration, v. 19, no. 2, p. 115-125.

Shuter, Eugene, and Pemberton, R. R., 1978, Inflatable straddle packers and associated equipment for hydraulic fracturing and hydrologic testing: U.S. Geological Survey Water-Resources Investigations 78-55, $20 \mathrm{p}$.

Stevens H. H., Jr., Ficke, J. F., and Smoot, G. F., 1975, Water temperature-Influential factors, field measurement and data presentation: U.S. Geological Survey Techniques of Water-Resources Investigations, Book 1, Chapter D1, $65 \mathrm{p}$.

Worthington, P. F., 1975, Procedures for the optimum use of geophysical methods in groundwater development programs: Bulletin of the Association of Engineering Geologists, v. 12 , no. 1, p. $23-38$.

1975, Quantitative geophysical investigations of granular aquifers: Geophysical Surveys, v. 2, no. 3, p. 313-366.
1976, Hydrogeophysical properties of parts of the British Trias: Geophysical Prospecting, v. 24, no. 4, p. 672-695.

Worthington, P. F., and Griffiths, D. H., 1975, The application of geophysical methods in the exploration and development of sandstone aquifers: Quarterly Journal of Engineering Geology, v. 8, no. 2, p. 73-102.

\section{CUARD LOC}

Doll, H. G., 1951, The laterolog-A new resistivity logging method with electrodes using an automatic focusing system: American Institute of Mining, Metallurgical, and Petroleum Engineers, Transactions, v. 192, p. 305-316.

1953, The microlaterolog: American Institute of Mining, Metallurgical, and Petroleum Engineers, Transactions, v. 198 , p. 17-32.

Guyod, Hubert, 1963, An investigation of the factors affecting the response of laterolog-type logging systems (LL3 and LL7): Society of Petroleum Engineers of the American Institute of Mining, Metallurgical, and Petroleum Engineers Paper SPE 714, 11 p.

1966, Examples of current distribution about laterolog sondes: Log Analyst, v. 7, no. 1, p. 27-32.

Jackson, P. D., 1981, Focussed electrical resistivity arraysSome theoretical and practical experiments: Geophysical Prospecting, v. 29, no. 4, p. 601-626.

Suau, J., and others, 1972, The dual laterolog- $R_{x o}$ tool: Society of Petroleum Engineers of the American Institute of Mining, Metallurgical, and Petroleum Engineers Paper SPE 4018, 12 p.

Zenor, H. M., and others, 1966, Focus log geometrical factors: Society of Professional Well Log Analysts Annual Logging Symposium, 7th, Tulsa, Okla., 1966, Transactions, p. R1R17.

\section{HYDRAULIC FRACTURING}

Blanks, G. L., 1976, Incorporation of temperature with gamma ray logging techniques in analyzing fracture placement: Stimulation of Low Permeability Reservoirs Symposium, Golden, Colo., 1976, Proceedings, p. 105-134.

Daniel, Gene, and White, Jerry, 1980, Fundamentals of fracturing: Society of Petroleum Engineers of the American Institute of Mining, Metallurgical, and Petroleum Engineers Paper SPE 9064, 8 p.

Gale, J. E., and Welhan, J. A., 1975, Hydrogeology of fractured media in the Halifax area: Environment Canada Report Series no. 42, p. 17-29.

Greenfield, R. J., and Shuck, L. Z., 1977, Hydraulic fracture mapping using electrical potential measurements: In Situ, v. 1, no. 2, p. 147-169.

Hanson, M. E., and others, 1977, Update on the LLL gas stimulation program: Annual ERDA Symposium on Enhanced Oil and Gas Recovery, 3d, Tulsa, Okla., 1977, Proceedings, UCRL-79587, $37 \mathrm{p}$.

Hubbert, M. K., and Willis, D. G., 1958, Mechanics of hydraulic fracturing: American Institute of Mining, Metallurgical, and Engineers Petroleum Transactions, 1957, v. 210, p. 153-166. 
Power, D. V., and others, 1975, Detection of hydraulic fracture orientation dimensions in cased wells: Society of Petroleum Engineers of the American Institute of Mining, Metallurgical, and Petroleum Engineers Paper SPE 5626, 7 p.

Shuter, Eugene, and Pemberton, R. R., 1978, Inflatable straddle packers and associated equipment for hydraulic fracturing and hydrologic testing: U.S. Geological Survey Water-Resources Investigations $78-55,20 \mathrm{p}$.

Tindell, W. A., and Neal, J. K., 1980, Evolution of fracturing in the Oak Hill field: Society of Petroleum Engineers of the American Institute of Mining, Metallurgical, and Petroleum Engineers Paper SPE 9067, 12 p.

Wolff, R. G., and others, 1975, Stress determination by hydraulic fracturing in subsurface waste injection: Journal of the American Water Works Association, v. 67, no. 9, p. 519-524.

Zoback, M. D., Healy, J. H., and Roller, J. C., 1977, Preliminary stress measurements in central California using the hydraulic fracturing technique: Pure Applied Geophysics, v. 115, no. 1-2, p. 135-152.

\section{IGNEOUS AND METAMORPHIC ROCKS}

Brotzen, Otto, Duran, Oscar, and Magnusson, K. A., 1980, Evaluation of geophysical borehole studies: Geological Survey of Sweden Report Prav 4.14, 47 p.

Crosby, J. W., III, and Anderson, J. V., 1971, Some applications of geophysical well logging to basalt hydrogeology: Ground Water, v. 9, no. 5, p. 12-20.

Daniels, J. J., Scott, J. H., and Hagstrum, J. T., 1981, Interpretation of geophysical well-log measurements in drill holes UE25a-4, $-5,-6$, and -7 , Yucca Mountain, Nevada Test Site: U.S. Geological Survey Open-File Report 81$389,31 \mathrm{p}$.

Davis, C. E., and Tammemagi, H. Y., 1981, A case history of a very deep borehole in the Canadian Shield: Atomic Energy of Canada Technical Record, $60 \mathrm{p}$.

Keller, G. V., Grose, L. T., and Pickett, G. R., 1978, Research on the physical properties of geothermal reservoir rock: U.S. Department of Energy, issued by the U.S. Department of Commerce, National Technical Information Service, Report COO-2908-3, 21 p.

Keys, W. S., 1979, Borehole geophysics in igneous and metamorphic rocks: Society of Professional Well Log Analysts Annual Logging Symposium, 20th, Tulsa, Okla., 1979, Transactions, p. 001-0026.

Nelson, P. H., and Glenn, W. E., 1975, Influence of bound water on the neutron log in mineralized igneous rocks: Society of Professional Well Log Analysts Annual Logging Symposium, 16th, New Orleans, La., 1975, Transactions, p. M1-M9.

Peterson, F. L., and Lao, Chester, 1970, Electric well logging of Hawaiian basaltic aquifers: Ground Water, v. 8, no. 2, p. 11-18.

Sembodo, P. B. V. D., 1973, Notes of formation evaluation in the Jatibarang volcanic reservoir: Indonesian Petroleum Association Annual Convention, 2d, Jakarta, 1973, Proceedings, p. 131-147.

\section{INDUCED POLARIZATION}

Bacon, L. O., 1965, Induced-polarization logging in the search for native copper: Geophysics, v. 30, no. 2, p. 246-256.

Bodmer, Rene, Ward, S. H., and Morrison, H. F., 1968, On induced electrical polarization and groundwater: Geophysics, v. 33, no. 5, p. 805-821.

Dakhnov, V. N., Latishova, M. G., and Ryapolov, V. A., 1967, Well logging by means of induced polarization (electrolytic logging): Log Analyst, v. 8, no. 3, p. 3-18.

Hauck, A. M., III, 1970, A reconnaissance downhole induced polarization and resistivity survey method: Society of Engineering Geologists Annual Meeting, New Orleans, La., 1970, Proceedings, p. 1-12.

Keller, G. V., 1967, Induced polarization well logging: Society of Professional Well Log Analysts Annual Logging Symposium, 8th, Denver, Colo., 1967, Transactions, p. W1W16.

Komarov, S. G., and Kotov, P. T., 1968, On determining formation permeability from induced polarization: Log Analyst, v. 9, no. 3, p. 12-17.

Lahman, H. S., and Vozoff, Keeva, 1967, The induced polarization technique for geophysical exploration: Cambridge, Mass., Geoscience Inc., 21 p.

Vacquier, Victor, and others, 1957, Prospecting for ground water by induced electrical polarization: Geophysics, v. 22, no. 3 , p. $660-687$.

\section{INDUCTION}

Boganik, V. N., 1966, Some data on the single-coil and two-coil systems for magnetic logging: Izvestiya Vysshikh Uchebnykh Zavedenij, Geologiya i Razvedka, v. 9, no. 11, p. 128-131, Glen Ridge, N.J., Associated Technical Services, $4 \mathrm{p}$.

Duesterhoeft, W. C., Jr., Hartline, R. E., and Thomsen, H. S., 1961, The effect of coil design on the performance of the induction log: Journal of Petroleum Technology, v. 13, no. 11, p. 1137-1150.

Dumanoir, J. L., Tixier, M. P., and Martin, Maurice, 1958, Interpretation of the induction-electrical $\log$ in fresh mud: American Institute of Mining, Metallurgical, and Petroleum Engineers Transactions, 1957, v. 210, p. 202-217.

Howard, A. Q., Jr., 1978, Effect of borehole fluid on induction fields of an encapsulated magnetic loop: Los Alamos Scientific Laboratory, issued by the U.S. Department of Commerce, National Technical Information Service, Report LA-7516-MS, 9 p.

Pirson, S. J., 1963, The inductively focused-current logs, in Handbook of well $\log$ analysis for oil and gas formation evaluation: Englewood Cliffs, N.J., Prentice-Hall, p. 159 175.

Tixier, M. P., and others, 1963, Dual induction-laterolog-A new tool for resistivity analysis: Society of Petroleum Engineers of the American Institute of Mining, Metallurgical, and Petroleum Engineers Paper SPE-713, 18 p.

Wait, J. R., and Hill, D. A., 1977, Electromagnetic shielding of sources within a metal-cased bore hole: Institute of Electrical and Electronics Engineers, Geoscience Electronics Transactions, v. GE-15, no. 2, p. 108-112. 
Woodhouse, Richard, and Taylor, P. A., 1974, The varying radial geometrical factors of the induction log: Society of Petroleum Engineers of the American Institute of Mining, Metallurgical, and Petroleum Engineers Paper SPE 4823, 8 p.

Woodhouse, Richard, Threadgold, Philip, and Taylor, P. A., 1975, The radial response of the induction tool: Log Analyst, v. 16, no. 1, p. 3-9.

\section{INJECTIVITY PROFILE}

Bearden, W. G., and others, 1970, Interpretation of injectivity profiles in irregular boreholes: Journal of Petroleum Technology, v. 22, no. 9, p. 1089-1097.

Ford, W. O., Jr., 1962, How new injectivity profiling method works: World Oil, v. 155, no. 2, p. 43-47.

Wiley, Ralph, and Cocanower, R. D., 1975, A quantitative technique for determining injectivity profiles using radioactive tracers: Society of Petroleum Engineers of the American Institute of Mining, Metallurgical, and Petroleum Engineers Paper SPE 5513, 9 p.

\section{INSTRUMENTATION}

Arkadyev, E. A., and others, 1976, New versatile nuclear and acoustic logger: Geofizikai Kozlemenyek, v. 24, p. 83-89.

Atkinson, Asher, and Pointer, Ralph, 1976, Logging services used for large diameter boreholes: Society of Petroleum Engineers of the American Institute of Mining, Metallurgical, and Petroleum Engineers Paper SPE 6155, 8 p.

Brown and Root, Inc., 1964, Scientific and technical progress for National Science Foundation Project Mohole: U.S. Department of Commerce, National Technical Information Service, Report PB175056, 64 p.

Idler, G. E., 1980, Modification of an electronic downhole water sampler: Ground Water, v. 18, no. 6, p. 532-535.

Johnson, A. I., 1963, Portable equipment for borehole geophysical exploration: U.S. Geological Survey open-file report, $24 \mathrm{p}$.

1964, An outline of equipment useful for hydrologic studies: U.S. Geological Survey open-file report, $24 \mathrm{p}$.

Lytle, R. J., and Dines, K. A., 1978, An impedance camera-A system for determining the spatial variation of electrical conductivity: Lawrence Livermore Laboratory, issued by the U.S. Department of Commerce, National Technical Information Service, Report UCRL 52413,11 p.

Scott, J. H., and Farstad, A. J., 1977, Electrical resistivity well-logging system with solid-state electronic circuitry: U.S. Geological Survey Open File Report 77-144, 27 p.

Seigel, H. O., and Nargolwalla, S. S., 1975, Nuclear logging system obtains 'bulk samples' from small boreholes: Engineering and Mining Journal, v, 176, no. 6, p. 101-103.

\section{INTERPRETATION MANUALS}

Birdwell Division, 1973, Geophysical well log interpretation: Tulsa, Okla., Seismograph Service Corp., 168 p.

Dresser Industries, 1981, Relating diplogs to practical geology: Houston, Tex., Dresser Atlas Division, 69 p.

1981, Log interpretation charts: Houston, Tex., Dresser Atlas Division, 116 p.
1982, Well logging and interpretation techniques-The course for home study: Houston, Tex., Dresser Atlas Division, 492 p.

Gearhart Industries, Inc., 1982, Log interpretation reference data handbook: Fort Worth, Tex., 226 p.

1982, Formation evaluation data handbook: Fort Worth, Tex., 240 p.

1982, Open hole log analysis: Fort Worth, Tex., Wireline Services Division, 136 p.

Guyod, Hubert, 1944, Fundamentals of electric log interpretation: Houston, Tex., Halliburton Co., Welex Division, 42 p.

1944, Guyod's electrical well logging: Houston, Tex., Halliburton Co., Welex Division, Bulletin A132, 103 p.

Hallenburg, J. K., and others, eds., 1982, Geothermal log interpretation handbook: Tulsa Okla., Society of Professional Well Log Analysts, 538 p.

Keys, W. S., and MacCary, L. M., 1971, Application of borehole geophysics to water-resources investigations: U.S. Geological Survey Techniques of Water-Resources Investigations, Book 2, Chapter E1, $126 \mathrm{p}$.

Pickett, G. R., 1972, Practical formation evaluation: Golden, Colo., 160 p.

Schlumberger Well Surveying Corporation, 1972, Principles of $\log$ interpretation: Houston, Tex., 112 p.

1974, Applications of $\log$ interpretation: Houston, Tex., $116 \mathrm{p}$.

1978, Log interpretation chartbook: Houston, Tex., 83 p.

1979, Log interpretation chartbook-English and metric: Houston, Tex., $97 \mathrm{p}$.

1981, Fundamentals of dipmeter interpretation: Houston, Tex., v. 1, $61 \mathrm{p}$.

Welex Division, 1968, Charts for the interpretation of well logs: Houston, Tex., Halliburton Co., 73 p.

\section{LITHOLOOY AND THICKNESS}

Bedwell, J. L., 1974, Textural parameters of clastic rocks from borehole measurements and their application in determining depositional environments [Colorado School of Mines, Ph. D. dissertation]: University Microfilms, International, Publication no. T 1621, 215 p.

Heslop, A., 1971, Mixed-lithology analysis using MN product: Canadian Well Logging Society Journal, v. 4, no. 1, p. 85-93.

Itoh, Toshinobu, and Hirakawa, Seiichi, 1973, Some aspects on well $\log$ interpretation of lithological analysis of shaly sand: Bulletin of the Japan Petroleum Institute, v. 15, no. 2, p. 172-179.

Mooney, R. T., III, 1980, The stratigraphy of the Floridan aquifer system east and northeast of Lake Okeechobee, Florida: South Florida Water Management District Technical Publication 80-9, 45 p.

Poupon, Andre, and Gaymard, R., 1970, The evaluation of clay content from logs: Society of Professional Well Log Analysts, Annual Logging Symposium, 11th, Los Angeles, Calif., 1970, Transactions, p. G1-G20.

Sharp, J. E., 1969, Structural geology and shaft construction [University of Arizona, M.S. thesis]: University Microfilms, International, Publication no. E 9791, 82 p. 


\section{LOCGING WHILE DRILLING}

Ainsworth, Cliff, 1978, Gentrix venting-pulse system solves erosion power problems, pt. 10 of Measurements while drilling - State of the art: Oil and Gas Journal, v. 76, no. 31, p. $153-160$.

Gearhart Industries, 1978, Gearhart-Owen uses negative pressure pulse, pt. 7 of Measurements while drilling-State of the art: Oil and Gas Journal, v. 75, no. 24, p. 70-72.

Godbey, J. J., 1978, System uses internal copper tubing, pt. 8 of Measurements while drilling-State of the art: Oil and Gas Journal, v. 76, no. 27, p. 72-76.

Institut Francais du Petrole, 1978, Flexodrill monitors borehole continuously, pt. 5 of Measurements while drilling-State of the art: Oil and Gas Journal, v. 76, no. 20, p. 69-71.

Kolker, M., and others, 1978, Raytheon downhole information system-Electromagnetic borehole measurements while drilling system, Final report: U.S. Department of Energy, issued by the U.S. Department of Commerce, National Technical Information Service, Report COO/2816-2, $70 \mathrm{p}$.

McDonald, W. J., 1978, MWD looks best for directional work and drilling efficiency, pt. 1 of Measurements while drilling -State of the art: Oil and Gas Journal, v. 76, no. 13, p. 141-147.

1978, Four different systems used for MWD, pt. 2 of Measurements while drilling-State of the art: Oil and Gas Journal, v. 76, no. 14, p. 115-124.

Oil and Gas Journal, 1978, Majors do basic research on MWD, pt. 9 of Measurements while drilling-State of the art: v .76, no. 36, p. 63-64.

1978, Acoustic, EM systems due in 1979, conclusion of Measurements while drilling -State of the art: v. 76, no. 36, p. 119-123.

Patton, B. J., and others, 1977, Development and successful testing of a continuous-wave, logging-while-drilling telemetry system: Journal of Petroleum Technology, v. 29, no. 10 , p. $1215-1222$.

Roberts, W. F., Jr., and Johnson, H. A., 1978, System is available for measuring hole direction, pt. 6 of Measurements while drilling - State of the art: Oil and Gas Journal, v. 76, no. 22, p. 68-76.

Spinnler, R. F., and Stone, F. A., 1978, MWD program nearing commerciality, pt. 4 of Measurements while drillingState of the art: Oil and Gas Journal, v. 76, no. 18, p. $59-66$.

Traynor, B. V., Jr., 1978, Electrodril demonstration program shows promise, pt. 3 of Measurements while drillingState of the art: Oil and Gas Journal, v. 76, no. 16, p. 109-129.

\section{MAGNETIC}

Douglas, A. C., and Millett, M. R., 1978, Total intensity magnetometer logging as a stratigraphic tool in Tertiary volcanic rock: Lawrence Livermore Laboratory, issued by the U.S. Department of Commerce, National Technical Information Service, Report UCRL -52617, 11 p.

Emilia, D. A., Allen, J. W., and Chessmore, R. B., 1981, The DOE/Simplec magnetic susceptibility logging system: Society of Professional Well Log Analysts Annual Logging Symposium, 22d, Mexico City, Mexico, 1981, Transactions, p. S1-S37.
Parker, R. L., and Daniell, G. J., 1979, Interpretation of borehole magnetometer data: Journal of Geophysical Research, v. 84, no. B10, p. 5467-5479.

Scott, J. H., Seeley, R. L., and Barth, J. J., 1981, A magnetic susceptibility well-logging system for mineral exploration: Society of Professional Well Log Analysts Annual Logging Symposium, 22d, Mexico City, Mexico, 1981, Transactions, p. CC1-CC21.

Silva, J. B. C., and Hohman, G. W., 1981, Interpretation of three-component borehole magnetometer data: Geophysics, v. 46, no. 12 , p. 1721-1731.

\section{MINERAL EXPLORATION BY LOCGING}

Clayton, C. G., and Packer, T. W., 1974, The use of energy dispersive $\mathrm{x}$-ray fluorescence techniques for analyzing borehole samples: Society of Professional Well Log Analysts European Logging Symposium, 3d, London, England, 1974, Transactions, p. Q1-Q20.

Czubek, J. A., 1971, Recent Russian and European developments in nuclear geophysics applied to mineral exploration and mining: $\log$ Analyst, v. 12, no. 6, p. $20-34$.

Daniels, J. J., and others, 1977, Borehole geophysical investigations in the South Texas uranium district: U.S. Geological Survey Journal of Research, v. 5, no. 3, p. 343-357.

Scott, J. H., and Daniels, J. J., 1976, Non-radiometric borehole geophysical detection of geochemical halves surrounding sedimentary uranium deposits, in Exploration for uranium ore deposits-A symposium, Vienna, 1976, Proceedings: Vienna, Austria, International Atomic Energy Agency, p. 379-390.

Scott, J. H., and others, 1975, Hole-to-hole geophysical measurement research for mineral exploration: Society of Professional Well Log Analysts Annual Logging Symposium, 16th, New Orleans, La., 1975, Transactions, p. KK1KK23.

Scott, J. H., and Tibbetts, B. L., 1974, Well-logging techniques for mineral deposit evaluation-A review: U.S. Bureau of Mines Information Circular 8627, $45 \mathrm{p}$.

Threadgold, Philip, 1970, Applications of well-logging techniques to mining exploration boreholes, in Mining and petroleum geology: Commonwealth Mining and Metallurgical Congress, 9th, London, England, 1969, Proceedings, p. 731-747.

\section{MOISTURE CONTENT}

Atkinson, Asher, 1971, A method to determine the in-situ content of alluvium and tuff formations at the Nevada Test Site: Tulsa, Okla., Seismograph Service Corp., Birdwell Division, $8 \mathrm{p}$.

Carroll, R. D., and Muller, D. C., 1973, Techniques for the quantitative determination of alluvial physical properties from geophysical logs, Southern Yucca Flat, Nevada Test Site: U.S. Geological Survey, issued by the U.S. Department of Commerce, National Technical Information Service, Report USGS-474-175, $113 \mathrm{p}$.

Gardner, W. H., Campbell, G. S., and Calissendorff, C., 1972, Systematic and random errors in dual gamma energy soil bulk density and water content measurements: Soil Science Society of America Journal, v. 36, no. 3, p. 393-398. 
Isaacson, R. E., Brownell, L. E., and Hanson, J. C., 1974, Soil moisture transport in arid site vadose zones: Atlantic Richfield Hanford Company, issued by the U.S. Department of Commerce, National Technical Information Service, Report ARH-2983, 95 p.

Wilson, L. G., 1981, Monitoring in the vadose zone, pt. 1Storage changes: Ground Water Monitoring Review, v. 1, no. 3 , p. 32-41.

\section{NEUTRON}

Abeele, W. V., 1978, The influence of access hole parameters on neutron moisture probe readings: Los Alamos Scientific Laboratory, issued by the U.S. Department of Commerce, National Technical Information Service, Report LA-7241MS, 5 p.

Alger, R. P., and others, 1971, The dual spacing neutron logCNL: Society of Petroleum Engineers of the American Institute of Mining, Metallurgical, and Petroleum Engineers Paper SPE 3565, $15 \mathrm{p}$.

Allen, L. S., Caldwell, R. L., and Mills, W. R., Jr., 1965, Borehole models for nuclear logging: Society of Petroleum Engineers Journal, v. 5, no. 2, p. 109-112.

Allen, L. S., and others, 1967, Dual-spaced neutron logging for porosity: Geophysies, v. 32, no. 1, p. 60-68.

Allen, L. S., and others, 1972, Some features of dual-spaced neutron porosity logging: Society of Professional Well Log Analysts Annual Logging Symposium, 13th, Tulsa, Okla., 1972, Transactions, p. G1-G11.

Ansell, K. H., and Hall, E. G., 1971, Recent developments in $(\alpha n)$ sources, in Neutron sources and applications: U.S. Department of Commerce, National Technical Information Service, Report CONF-710402, v. 2, p. I90-I99.

Arnold, D. M., and Smith, H. D., Jr., 1981, Experimental determination of environmental corrections for a dual-spaced neutron porosity log: Society of Professional Well Log Analysts Annual Logging Symposium, 22d, Mexico City, Mexico, 1981, Transactions, v. 2, p. VV1-VV24.

Belcher, D. J., Cuykendall, T. R., and Sack, H. S., 1950, The measurement of soil moisture and density by neutron and gamma-ray scattering: Civil Aeronautics Administration Technical Development Report no. 127, 20 p.

Buckner, G. O., 1965, Numerical application of neutron lifetime interpretation: Society of Professional Well Log Analysts Annual Logging Symposium, 6th, Dallas, Tex., Transactions, v. 2, p. F1-F14.

Caldwell, R. L., 1969, Nuclear logging methods: Isotope and Radiation Technology, v. 6, no. 3, p. 257-273.

Caldwell, R. L., Allen, L. S., and Mills, W. R., Jr., 1966, Theoretical and experimental model results in neutron lifetime logging, in Radioisotope instruments in industry and geophysics: International Atomic Energy Agency Symposium, Warsaw, Poland, 1965, Proceedings, v. 2, p. $69-83$.

Cameron, J. F., ed., 1970, Neutron moisture gauges: International Atomic Energy Agency Technical Reports Series no. $112,96 \mathrm{p}$.

Corey, J. C., Boulogne, A. R., and Horton, J. H., 1970, Determination of soil density and water content by fast neutrons and gamma rays: Water Resources Research, v. 6, no. 1, p. 223-229.
Cotecchia, Vincenzo, and others, 1968, Influence of the physical and chemical properties of soil on measurements of water content using neutron probes: Water Resources Research, v. 4, no. 5, p. 1023-1028.

Currie, R. L., McCrosson, F. J., and Parks, P. B., 1971, Flux enhancement with ${ }^{252} \mathrm{Cf}$ source in a subcritical assembly, in Neutron sources and applications: U.S. Department of Commerce, National Technical Information Service, Report CONF-710402, v. 2, p. I136-I147.

Davis, R. R., and others, 1981, A dual porosity CNL logging system: Society of Petroleum Engineers of the American Institute of Mining, Metallurgical, and Petroleum Engineers Paper SPE 10296, 7 p.

Denoo, Stan, 1978, Neutron density log is a valuable open-hole porosity tool: Oil and Gas Journal, v. 76, no. 39, p. 96, 101-102.

Dewan, J. T., and others, 1973, Thermal neutron decay log ging using dual detection: Log Analyst, v. 14, no. 5, p. 13-25.

Dewan, J. T., Stone, O. L., and Morris, R. L., 1960, Results of chlorine logging in cased holes: Society of Petroleum Engineers of the American Institute of Mining, Metallurgical, and Petroleum Engineers Paper 1561-G, 14 p.

1961, Chlorine logging in cased holes: Journal of Petroleum Technology, v. 13 , no. 6 , p. 531-537.

Edwards, J. M., and Simpson, A. I., 1955, A method for neutron derived porosity determination for thin beds: American Institute of Mining, Metallurgical, and Petroleum Engineers Transactions, v. 204, p. 1-6.

Elkington, P. A. S., Stouthamer, P., and Brown, J. R., 1982, Rock strength predictions from wireline logs: International Journal of Rock Mechanics, Mineral Sciences, and Geomechanical Abstracts, v. 19, no. 2, p. 91-97.

Ellis, D. V., Ullo, J. J., and Sherman, Harold, 1981, Comparison of calculated and measured responses of a dual-detector epithermal neutron porosity device: Society of Petroleum Engineers of the American Institute of Mining, Metallurgical, and Petroleum Engineers Paper SPE 10294, $8 \mathrm{p}$.

Enrique, H. J., and Salisch, H. A., 1972, The dual spacing neutron log (CNL) in Venezuela: Society of Professional Well Log Analysts Annual Logging Symposium, 13th, Tulsa, Okla., 1972, Transactions, p. T1-T21.

Fearon, R. E., and Mardock, E. S., 1952, The quantitative interpretation of radioactivity logs: Oil and Gas Journal, v. 50, no. 46, p. $188,190-194$.

Feldman, I. I., 1963, The discovery of manganese beds by neutron methods of examining boreholes: New York, Consultants Bureau Enterprises, Inc., Industrial and Exploratory Geophysical Prospecting, Transactions of the Ministry of Intermediate and Higher Specialized Education of the Russian Soviet Federated Socialist Republic, no. 31 , p. $44-46$.

1963, The discovery and study of boron-bearing beds by neutron methods of investigating boreholes: New York, Consultants Bureau Enterprises, Inc., Industrial and Exploratory Geophysical Prospecting, Transactions of the Ministry of Intermediate and Higher Specialized Education of the Russian Soviet Federated Socialist Republic, no. 31 , p. $47-52$. 
1965, Identification and description of boron deposits from neutron logging: International Geology Review, v. 7, no. 1, p. 11-16.

Ferronsky, V. I., 1971, Neutron techniques in ground water exploration in Neutron sources and applications: U.S. Department of Commerce, National Technical Information Service, Report CONF-710402, v. 3, p. III4-III58.

Gardner, R. P., and Roberts, K. F., 1967, Neutron gauges for measuring soil moisture content, in Density and moisture content measurements by nuclear methods-National Cooperative Highway Research Program Report 43, Part II: Washington, D.C., National Academy of Sciences, p. $20-40$.

Gardner, Wilford, and Kirkham, Don, 1951, Determination of soil moisture by neutron scattering: Soil Science, v. 73, no. 5 , p. 391-401.

Givens, W. W., Caldwell, R. L., and Mills, W. R., Jr., 1968, Cyclic activation logging: Log Analyst, v. 9, no. 3, p. 1821.

Greacen, E. L., and Schrale, G., 1976, The effect of bulk density on neutron meter calibration: Australian Journal of Soil Research, v. 14, no. 2, p. 159-169.

Grosmangin, Michel, and Walker, E. B., 1958, Gas detection by dual-spacing neutron logs in the Greater Oficina area, Venezuela: American Institute of Mining, Metallurgical, and Petroleum Engineers Transactions, 1957, v. 210, p. 140-147.

Guy, J. O., Youmans, A. H., and Smith, W. D. M., 1971, The sidewall acoustic neutron log: Society of Professional Well Log Analysts Annual Logging Symposium, 12th, Dallas, Tex., 1971, Transactions, p. X1-X16.

Hall, J. E., and others, 1980, A new thermal neutron decay logging system-TDT-M: Society of Petroleum Engineers of the American Institute of Mining, Metallurgical, and Petroleum Engineers Paper SPE 9462, 12 p.

Hearst, J. R., 1968, Effects of medium variations on the measurement of in-situ hydrogen content: Geophysics, v. 33, no. 4 , p. $657-667$.

1974, Effects of bulk density on calculated neutron log response: Nuclear Instruments and Methods, v. 117, no. 1, p. 141-151.

1974, On the comparison of the data from an epithermal neutron log to water content measured from in situ samples in Yucca Flat, Nevada Test Site: U.S. Department of Commerce, National Technical Information Service, Report UCID-16475, 12 p.

1975, Neutron logging in partially saturated media: Society of Professional Well Log Analysts Annual Logging Symposium, 16th, New Orleans, La., Transactions, 1975, p. I1-I19.

1979, Calibration of a neutron $\log$ in partially saturated media: Society of Professional Well Log Analysts Annual Logging Symposium, 20th, Tulsa, Okla., 1979, Transactions, v. 1, p. B1-B28.

Hearst, J. R., Kasameyer, P. W., and Dreiling, L. A., 1981, Calibration of a neutron $\log$ in partially saturated media, Part II-Error analysis: Society of Professional Well Log Analysts Annual Logging Symposium, 22d, Mexico City, Mexico, 1981, Transactions, v. 2, p. QQ1-QQ47.
Holgate, M. M., 1960, The microlog as a porosity datum for the neutron $\log$ in the Swan Hills Field, Alberta: Canadian Mining and Metallurgical Bulletin, v. 53, no. 579, p. 502506.

Horonjeff, Robert, and Goldberg, Irving, 1953, Field measurements of soil moisture and density with radioactive materials: Highway Research Board Annual Meeting, 32d, Washington, D.C., 1953, Proceedings, p. 500-511.

Johnson, A. I., 1962, Methods of measuring soil moisture in the field: U.S. Geological Survey Water-Supply Paper 1619-U, p. U1-U25.

Kok, K. D., Artigas, Ricardo, and Ray, J. W., 1971, Effects of source encapsulation materials on the thermal-neutron flux from a Cf source in a water moderator, in Neutron sources and applications: U.S. Department of Commerce, National Technical Information Service, Report CONF710402, v. 2, p. I84-I89.

Kreft, Andrzej, 1973, The question of the fast neutron absorption in moisture measurements by the neutron method: Warsaw, Nuclear Energy Information Center of the Polish Government, Commissioner for Use of Nuclear Energy, Palace of Culture and Science, Report 33/I, $18 \mathrm{p}$.

Kukharenko, N. K., and Basin, Y. N., 1961, Modernization of radioactivity apparatus: Yadernaya Geofizika 19-26, issued by the U.S. Department of Commerce, National Technical Information Service, Report AEC-TR-6577, 11 p.

Lane-Wells Company, 1964, The neutron lifetime log workbook: Houston, Tex., 10 p.

Lehnert, K., 1962, On the calibration and interpretation of neutron-gamma logs in the German Democratic Republic: Nuclear Geophysicists Conference, Cracow, Poland, 1962, Proceedings, v. 1, p. 147-164.

Majerczyk, J., and Zuber, A., 1966, The influence of composition of soils on readings of neutron moisture meters, in Radioisotope instruments in industry and geophysics: International Atomic Energy Agency Symposium, Warsaw, Poland, 1965, Proceedings, v. 2, p. 383-397.

Marquis, G. L., 1964, The neutron lifetime log: Houston, Tex., Lane-Wells Co., 15 p.

McDonnell, W. R., and others, 1971, Preparation of industrial ${ }^{252} \mathrm{Cf}$ neutron sources at Savannah River Laboratory, in Neutron sources and applications: U.S. Department of Commerce, National Technical Information Service, Report CONF-710402, v. 2, p. I72-I83.

McHenry, J. R., 1962, Theory and application of neutron scattering in the measurement of soil moisture: Soil Science, v. 95 , no. 5, p. $294-307$.

McKinlay, P. F., and Tanner, H. L., 1973, The shale compensated chlorine log: Society of Petroleum Engineers of the American Institute of Mining, Metallurgical, and Petroleum Engineers Paper SPE 4511, 5 p.

McKinney, F. E., 1969, Measuring moisture with gamma radiation: Isotopes and Radiation Technology, v. 7 , no. 1, p. $29-35$.

Meyer, G. L., 1971, Applications of neutron sources to groundwater hydrology, in Neutron sources and applications: U.S. Department of Commerce, National Technical Information Service, Report CONF-710402, v. 1, p. III21III36. 
Meyer, W. R., 1962, Use of a neutron moisture probe to determine the storage coefficient of an unconfined aquifer, in Geological Survey Research 1962: U.S. Geological Survey Professional Paper 450-E, p. E174-E176.

Mooring, J. F., 1961, The spectral $\log$ for chlorine detection: Society of Professional Well Log Analysts Annual Logging Symposium, 2d, Dallas, Tex., 1961, Transactions, p. 1-13.

Nelligan, W. B., and Antkiw, Stephen, 1976, Accurate thermal neutron decay time measurements with the dual-spacing TDT-A laboratory study: Society of Petroleum Engineers of the American Institute of Mining, Metallurgical, and Petroleum Engineers Paper SPE 6156, 12 p.

Nelson, P. H., and Glenn, W. E., 1975, Influence of bound water on the neutron log in mineralized igneous rock: Society of Professional Well Log Analysts Annual Logging Symposium, 16th, New Orleans, La., 1975, Transactions, p. M1-M19.

Olgaard, P. L., 1965, On the theory of the neutronic method for measuring the water content in soil: Riso, Roskilde, Denmark, Atomic Energy Commission, Riso Report 97, $44 \mathrm{p}$.

Paap, H. J., and Scott, H. D., 1971, The use of ${ }^{252} \mathrm{Cf}$ as a neutron source for well logging, in Neutron sources and applications: U.S. Department of Commerce, National Technical Information Service, Report CONF-710402, v. 3, p. III30-III35.

Peterson, F. L., 1974, Neutron well logging in Hawaii: Honolulu, University of Hawaii, Water Resources Research Center Technical Report no. 75, 42 p.

Petroleum Engineer, 1957, Porosity evaluation of radiation logs: v. 29, no. 11, p. B95-B102.

Preiss, Kenneth, and Haccoun, A., 1970, A feasibility study of a method for measuring chloride content of water in a borehole by neutron moderation: Beer-Sheva, Israel, Negev Institute for Arid Zone Research, Division of Engineering Sciences Departmental Report 109, 17 p.

Przewlocki, K., 1962, The model study of the neutron methods for the soil water determination: Nuclear Geophysicists Conference, Cracow, Poland, 1962, Proceedings, p. 835849.

Rabson, W. R., 1958, Neutron log tools require calibration and standardization: Drilling, v. 20, no. 2, p. 71.

1959, Chlorine detection by the spectral log: Petroleum Engineer, v. 31, no. 3, p. B102-B111.

1965, PH-125, Epithermal neutron log porosity evaluation: Houston, Tex., Pan Geo Atlas Corp., 21 p.

Ralston, D. R., 1967, Influence of water well design on neutron logging: Tempe, University of Arizona, M.S. thesis, $101 \mathrm{p}$.

Robinson, J. D., 1974, Neutron decay time in the subsurfaceTheory, experiment, and an application to residual oil determination: Society of Petroleum Engineers of the American Institute of Mining, Metallurgical, and Petroleum Engineers Paper SPE 5119, 17 p.

Ross, E. W., and others, 1982, Nuclear logging and geothermal log interpretation-Formation temperature sonde evaluation: Los Alamos Scientific Laboratory, issued by the U.S. Department of Commerce, National Technical Information Service, Report LA-9159-MS, 46 p.
Rybach, L., and Youmans, A. H., 1968, New nuclear logging methods: Sonderdruck aus Bulletin der Schweizerischer Petroleum-Geologen und Ingenieure, v. 35 , no. 86 , p. 34 51.

Sanders, L. C., Wormald, M. R., and Clayton, C. G., 1974, Formation evaluation by neutron interaction techniques: Society of Professional Well Log Analysts European Symposium, 3d, London, England, 1974, Transactions, p. L1L17.

Segesman, F. F., and Liu, Olive, 1971, The excavation effect: Society of Professional Well Log Analysts Annual Logging Symposium, 12th, Dallas, Tex., 1971, Transactions, p. N1N24.

Senftle, F. E., and others, 1983, Water analyses in salt deposits used for radioactive waste depositories: International Journal of Applied Radiation and Isotopes, v. 34, no. 1 , p. $389-396$.

Smith, H. D., Jr., 1979, Neutron logging: Houston, Tex., Welex Division Technical Brochure EL1016, 17 p.

Steinman, D. K., and others, $1980,{ }^{252} \mathrm{Cf}$-based direct uranium logging system: U.S. Department of Commerce, National Technical Information Service, Report IRT0053-016-I, $103 \mathrm{p}$.

Tanner, A. B., and others, 1971, A borehole sonde using a ${ }^{252} \mathrm{Cf}$ source and a $\mathrm{Ge}[\mathrm{Li}]$ detector cooled by a melting cryogen, in Neutron sources and applications: U.S. Department of Commerce, National Technical Information Service, Report CONF-710402, v. 3, p. III1-III6.

Tittle, C. W., 1961, Theory of neutron logging: Geophysics, v. 26 , no. 1 , p. $27-39$.

1962, Some problems in the theory of neutron logging: Nuclear Geophysicists Conference, Cracow, Poland, 1962, v. 1, Proceedings, p. 73-94.

Tittman, Jay, 1955, Moderation of neutrons in $\mathrm{SiO}_{2}$ and $\mathrm{CaCO}_{2}$ : Journal of Applied Physics, v. 26, no. 4, p. 394 398.

Tittman, Jay, and others, 1965, The sidewall epithermal neutron porosity log: Society of Petroleum Engineers of the American Institute of Mining, Metallurgical, and Petroleum Engineers Paper SPE 1180, 20 p.

Truman, R. B., and others, 1972, Progress report on interpretation of the dual-spacing neutron $\log (\mathrm{CNL})$ in the U.S.: Society of Professional Well Log Analysts Annual Logging Symposium, 13th, Tulsa, Okla., 1972, Transactions, p. U1U34.

Ullo, J. J., 1981, Response of the dual spacing neutron log (CNL) to gas: Society of Petroleum Engineers of the American Institute of Mining, Metallurgical, and Petroleum Engineers Paper SPE 10295, 11 p.

U.S. Forest Service, 1965, Access tubes and timers for use with nuclear soil moisture meters: Columbus, Ohio, U.S. Forest Service Research Note CS-30, 4 p.

1965, Checking the calibration of nuclear soil moisture and density measuring equipment: Columbus, Ohio, U.S. Forest Service Research Note CS-31, 4 p.

1965, Volumes of field soil and of water measured by subsurface nuclear probes: Columbus, Ohio, U.S. Forest Service Research Note CS-32, 5 p. 
Utegenov, S. M., 1964, The effects of mineral composition of hydrochemical sediments on the resolving power of neutron-gamma logging and determination of boron content in these sediments: Izvestiya Akademii Nauk Kazakhskoj SSR, Seriya Geologicheskaya, v. 1, p. 70-73, issued by the U.S. Department of Commerce, National Technical Information Service, Report TT-65-12269, 8 p.

Van Bavel, C. H. M., Nielsen, D. R., and Davidson, J. M., 1961, Calibration and characteristics of two neutron moisture probes: Soil Science Society of America Proceedings, v. 25 , no. 5 , p. $329-333$.

Veach, C. L., and Wheatley, J. C., 1977, A look at the development of neutron logging: Southwestern Petroleum Short Course Association Annual Meeting, 24th, Lubbock, Tex., 1977, Proceedings, p. 105-112.

Wahl, J. S., and others, 1968, The thermal neutron decay time log: Society of Petroleum Engineers of the American Institute of Mining, Metallurgical, and Petroleum Engineers Paper SPE 2252, 15 p.

Walters, E. J., 1968, Statistical study of neutron logs for correlation studies: Society of Professional Well Log Analysts Annual Logging Symposium, 9th, New Orleans, La., 1968, Transactions, p. F1-F15.

Wichmann, P. A., 1973, Notes on the accuracy of the neutron lifetime measurement: Log Analyst, v. 14, no. 3, p. 11-18.

Wichmann, P. A., Youmans, A. H., and Hopkinson, E. C., 1967, Advances in neutron lifetime logging: Journal of Petroleum Technology, v. 19, no. 4, p. 479-486.

Wilson, B. F., and Wichmann, P. A., 1974, The compensated neutron $\log$ and the effects of environment: Society of Petroleum Engineers of the American Institute of Mining, Metallurgical, and Petroleum Engineers Paper SPE 5118, $18 \mathrm{p}$.

Wilson, R. G., 1971, Methods of measuring soil moisture: Ottawa, Canada, Canadian National Committee for the International Hydrological Decade Technical Series no. 1, 20 p.

Winn, R. H., 1957, Log interpretation in heterogeneous carbonate reservoirs: Journal of Petroleum Technology, v. 9, no. 9 , p. $268-274$.

Wood, R. D., 1966, The gamma ray-neutron log: Houston, Tex., Lane-Wells Co., 16 p.

Woolson, W. A., and Gritzner, M. L., 1979, Evaluation models for uranium exploration by active neutron logging: Society of Professional Well Log Analysts Annual Logging Symposium, 20th, Tulsa, Okla., 1979, Transactions, v. 2, p. BB1-BB25.

Yakubson, K. L., and Guberman, Sh. A., 1963, Experimental investigation of space-energy distribution of neutrons in a model bed: New York, Consultants Bureau Enterprises, Inc., Industrial and Exploratory Geophysical Prospecting, Transactions of the Ministry of Intermediate and Higher Specialized Education of the Russian Soviet Federated Socialist Republic, no. 31, p. 47-52.

Yemel'yanov, V. A., and others, 1963, Neutron method for measuring soil moisture content and its future: Soviet Soil Science, no. 7, p. 708-714.

Youmans, A. H., Bishop, W. D., and Wichmann, P. A., 1970, Applications of the neutron lifetime $\log$ in new wells: Society of Professional Well Log Analysts Annual Logging Symposium, 11th, Los Angeles, Calif., 1970, Transactions, p. N1-N20.
Youmans, A. H., and Hopkinson, E. C., 1964, The neutron lifetime log: Society of Professional Well Log Analysts Annual Logging Symposium, 5th, Midland, Tex., 1964, Transactions, p. M1-M26.

Youmans, A. H., Hopkinson, E. C., and Wichmann, P. A., 1966, Neutron logging in theory and practice: Society of Professional Well Log Analysts Annual Logging Symposium, 7th, Tulsa, Okla., 1966, Transactions, p. Q1-Q17.

Youmans, A. H., and Monaghan, Ralph, 1958, Stability requirements for scintillation counters used in radioactivity logging: American Institute of Mining, Metallurgical, and Petroleum Engineers Transactions, 1957, v. 210, p. 231234.

Youmans, A. H., and others, 1963, A study of neutron logs for chlorine detection: Society of Professional Well Log Analysts Annual Logging Symposium, 4th, Oklahoma City, Okla., 1963, Transactions, p. V1-V20.

Youmans, A. H., and others, 1964, Neutron lifetime, a new nuclear log: Journal of Petroleum Technology, v. 16, no. 3, p. $319-328$.

Zuber, A., and Cameron, J. F., 1966, Neutron soil moisture gauges: Atomic Energy Review, v. 4, no. 4, p. 143-167.

\section{NEUTRON ACTIVATION}

Baker, P. E., 1957, Neutron capture gamma-ray spectra of earth formations: Journal of Petroleum Technology, v. 9, no. 3, p. 97-101.

Caldwell, R. L., Mills, W. R., Jr., and Hickman, J. B., Jr., 1960 , Gamma radiation from inelastic scattering of $14-\mathrm{Mev}$ neutrons by the common earth elements: Nuclear Science and Engineering, v. 8, p. 172-182.

Caldwell, R. L., and others, 1966, Combination neutron experiment for remote analysis: Science, v. 152, no. 3721, p. 457-465.

Culver, R. B., Hopkinson, E. C., and Youmans, A. H., 1974, Carbon/oxygen $(\mathrm{C} / 0)$ logging instrumentation: Society of Petroleum Engineers Journal, v. 14, no. 5, p. 463-470.

Czubek, J. A., 1972, Pulsed neutron method for uranium well logging: Geophysics, v. 37, no. 1, p. 160-173.

Duffey, D., El-Kady, A., and Senftle, F. E., 1970, Analytical sensitivities and energies of thermal-neutron-capture gamma rays: Nuclear Instruments and Methods of Physics Research, v. 80, no. 1, p. 149-171.

Engesser, F. C., and Thompson, W. E., 1967, Gamma rays resulting from interactions of $147 \mathrm{MeV}$ neutrons with various elements: Journal of Nuclear Energy, v. 21, p. 487507.

Flaum, Charles, and Pirie, Gordon, 1981, Determination of lithology from induced gamma-ray spectroscopy: Society of Professional Well Log Analysts Annual Logging Symposium, 22d, Mexico City, Mexico, 1981, Transactions, p. H1-H16.

Fletcher, J. W., and Walter, Jerry, 1978, A practical shale compensated chlorine log: Society of Professional Well Log Analysts Annual Logging Symposium, 19th, El Paso, Tex., 1978, Transactions, p. GG1-GG11.

Gallagher, M. J., 1970, Portable x-ray spectrometer for rapid ore analysis, in Mining and petroleum geology: Institution of Mining and Metallurgy Commonwealth Mining and Metallurgical Congress, 9th, London, England, 1969, Proceedings, v. 2, p. 691-729. 
Givens, W. W., Mills, W. R., Jr., and Caldwell, R. L., 1970, Cyclic activation analysis: Nuclear Instruments and Methods in Physies Research, v. 80, no. 1, p. 95-103.

Givens, W. W., and others, 1976, Uranium assay logging using a pulsed 14-Mev neutron source and detection of delayed fission neutrons: Geophysics, v. 41, no. 3, p. 468-490.

Gorshkov, G. V., and Tsvetkov, O. S., 1966, Neutron radiation of natural formations, in Vinogradov, A. P., ed., Chemistry of the Earth's crust: Jerusalem, Israel, S. MonsonWinery Bindery, Ltd., v. 2, p. $433-449$.

Hilchie, D. W., 1974, Neutron accelerator well logging, in Morgan, I. L., and Duggan, J. L., eds., Conference on Application of Small Accelerators, 3d, Denton, Tex., 1974, Proceedings: U.S. Department of Commerce, National Technical Information Service, Report CONF-741040-P2, v. 2, p. 166-173.

Hertzog, R. C., 1980, Laboratory and field evaluation of an inelastic neutron scattering and capture gamma ray spectrometry tool: Society of Petroleum Engineers of the American Institute of Mining, Metallurgical, and Petroleum Engineers Paper SPE 7430, 13 p.

Isenhour, T. L., and Morrison, G. H., 1966, Modulation technique for neutron capture gamma ray measurements in activation analysis: Analytical Chemistry, v. 38, no. 2, p. 162-167.

Jameson, J. B., and others, 1977, Dual-spacing TDT applications in marginal conditions: Journal of Petroleum Technology, v. 29, no. 9, p. 1067-1077.

Jensen, C. M., and others, 1977, Borehole logging with neutron activation, a laboratory assessment: U.S. Bureau of Mines Open-File Report 147-77, 40 p.

Keys, W. S., and Boulogne, A. R., 1969, Well logging with Californium-252: Society of Professional Well Log Analysts Annual Logging Sympsoium, 10th, Houston, Tex., 1969, Transactions, p. P1-P25.

Landstrom, Ove, Christell, Roland, and Koski, Keijo, 1972, Field experiments on the application of neutron activation techniques to in situ borehole analysis: Geoexploration, v. 10 , no. 1 , p. 23-29.

Landstrom, Ove, Samsahl, K., and Wenner, C. G., 1967, An investigation of trace elements in marine and lacustrine deposits by means of a neutron activation method: Stockholm, Sweden, Aktiebolaget Atomenergi, Publication AE296, 40 p.

Landstrom, Ove, and Wenner, C. G., 1966, Neutron activation analysis of natural water: Stockholm, Sweden, Aktiebolaget Atomenergi, Publication AE-204, 27 p.

Lawrence, T. D., 1979, Continuous carbon/oxygen log interpretation techniques: Society of Petroleum Engineers of the American Institute of Mining, Metallurgical, and Petroleum Engineers Paper SPE 8366, 12 p.

Lock, G. A., and Hoyer, W. A., 1973, Carbon-oxygen (C/O) log: Society of Petroleum Engineers of the American Institute of Mining, Metallurgical, and Petroleum Engineers Paper SPE 4639, 12 p.

Mardock, E. S., 1960, Radioactivity logging and its future potential: Geophysics, v. 25 , no. 4, p. 883-890.

McWhirter, V. C., 1976, Introduction to carbon logging: Society of Petroleum Engineers of the American Institute of Mining, Metallurgical, and Petroleum Engineers Paper SPE 5096, 13 p.
Meyer, V. A., and Nakhabtsev, V. S., 1965, Results of experimental use of $x$-ray radiometric logging in central Kazakhstan: Series Geoligii i Geografii no. 2, p. 65-73:, issued by the U.S. Department of Commerce, National Technical Information Service, Report TT 67-60663, 12 p.

Moxham, R. M., and Tanner, A. B., 1977, High-resolution gamma-ray spectrometry in uranium exploration: U.S. Geological Survey Journal of Research, v. 5, no. 6, p. 783795.

Muench, N L., and Osoba, J. S., 1957, Identification of earth materials by induced gamma-ray spectral analysis: Journal of Petroleum Technology, v. 9, no. 3, p. 89-92.

Peters, C. W., and Karaoglan, E. I., 1979, Calculated timecorrelated neutron-induced radiations in a sandstone formation: Bendix Field Engineering Corporation, issued by the U.S. Department of Commerce, National Technical Information Service, Report GJBX-80 79, 99 p.

Philbin, Phillip, and Senftle, F. E., 1971, Field activation analysis of uranium ore using ${ }^{252} \mathrm{Cf}$ neutron source: Society of Mining, Metallurgical, and Petroleum Engineers Transactions, v. 250, p. 102-106.

Renken, J. H., 1978, Analysis of pulsed neutron uranium logging signals to minimize effects of trace neutron absorbers in the rock formation: Sandia National Laboratory, issued by the U.S. Department of Commerce, National Technical Information Service, Report SAND 78-0328, 17 p.

Schmotzer, J. K., Jester, W. A., and Parizek, R. R., 1973, Groundwater tracing with post sampling activation analysis: Journal of Hydrology, v. 20, p. 217-326.

Schultz, W. E., and Smith, H. D., Jr., 1973, Laboratory and field evaluation of a carbon/oxygen well logging system: Society of Petroleum Engineers of the American Institute of Mining, Metallurgical, and Petroleum Engineers Paper SPE 4638, 12 p.

Scott, H. D., and Smith, M. P., 1973, The aluminum activation log: Society of Professional Well Log Analysts Annual Logging Symposium, 14th, Lafayette, La., 1973, Transactions, p. F1-F25.

Senftle, F. E., and Hoyte, A. F., 1966, Mineral exploration and soil analysis using in situ neutron activation: Nuclear Instruments and Methods in Physics Research, v. 42, no. 1, p. 93-103.

Senftle, F. E., Moxham, R. M., and Tanner, A. B., 1972, A comparison of radiative capture with decay gamma-ray method in borehole logging for economic minerals: Nuclear Instruments and Methods in Physics Research, v. 104, no. 3 , p. $485-492$.

Senftle, F. E., and others, 1971, Nickel exploration by neutron capture gamma rays: Economic Geology, v. 66, no. 4, p. 583-590.

Senftle, F. E., and others, 1977, Importance of neutron energy distribution in borehole activation analysis in relatively dry, low-porosity rocks: Geoexploration, v. 15, no. 15 , p. 121-135.

Steinman, D. K., and others, 1976, Future research in borehole assaying technology: San Diego, Calif., IRT Corp. 325 p.

Tanner, A. B., and others, 1972, A probe for neutron activation analysis in a drill hole using $151-\mathrm{Cf}$ and a $\mathrm{Ge}(\mathrm{Li})$ detector cooled by melting cryogen: Nuclear Instruments and Methods in Physies Research, v. 100, no. 1, p. 1-7. 
Wainerdi, R. E., and Fite, L. E., 1964, Activation analysis as applied to the petroleum industry: Society of Professional Well Log Analysts Annual Logging Symposium, 5th, Midland, Tex., 1964, Transactions, p. C1-C9.

Wichmann, P. A., 1971, Neutron activation for elemental determination in boreholes: Log Analyst, v. 13, no. 1, p. 10-18.

Woolson, W. A., and Gritzner, M. L., 1977, Borehole model calculations for direct uranium measurement with neutrons: U.S. Energy Research and Development Administration, issued by the U.S. Department of Commerce, National Technical Information Service, Report GJBX44(77), 114 p.

\section{NUCLEAR MAGNETIC RESONANCE}

Artus, D. S., 1969, Nuclear magnetism log can find porosity, water-cut: World Oil, v. 169 , no. 7 , p. 89-92.

Brown, R. S., and Neuman, C. H., 1982, The nuclear magnetism $\log -\mathbf{A}$ guide for field use: Log Analyst, v. 23, no. 5, p. 4-9.

Cook, J. C., 1977, Electromagnetic resonance borehole assay logging: U.S. Bureau of Mines Open-File Report 69-78, 99 p.

Gamson, B. W., and others, 1964, Nuclear magnetism logging field results: Journal of Petroleum Technology, v. 16, no. 2, p. 150-156.

Gullyev, C., 1966, An apparatus for measuring the moisture content of rocks by nuclear magnetic resonance: Razvedochnaya i Promyslovaya Geofizika, no. 10, p. 122-129, issued by Menlo Park, Calif. Addis Translations International, UCRL-Translation 10105, 12 p.

Herrick, R. C., Couturie, S. H., and Best, D. L., 1979, An improved nuclear magnetism logging system and its application to formation evaluation: Society of Petroleum Engineers of the American Institute of Mining, Metallurgical, and Petroleum Engineers Paper SPE 8361, 7 p.

Jackson, J. A., 1980, New NMR well logging/fracture mapping technique with possible application of squid NMR detection: Los Alamos Scientific Laboratory, issued by the U.S. Department of Commerce, National Technical Information Service, Report LA-UR-81-1619, 5 p.

Jackson, J. A., Brown, J. A., and Crawford, T. R., 1981, Remote characterization of tight gas formations with a new NMR logging tool: Society of Petroleum Engineers of the American Institute of Mining, Metallurgical, and Petroleum Engineers/Department of Energy Low Permeability Symposium, Denver, Colo., 1981, Proceedings, p. 313-315.

Loren, J. D., 1972, Permeability estimates from NML measurements: Journal of Petroleum Technology, v. 24, no. 8 , p. 923-928.

Neuman, C. H., and Brown, R. S., 1981, Applications of nuclear magnetism logging to formation evaluation: Society of Petroleum Engineers of the American Institute of Mining, Metallurgical, and Petroleum Engineers Paper SPE 10108, $10 \mathrm{p}$.

Timur, Aytekin, 1969, producible porosity and permeability of sandstones investigated through nuclear magnetic resonance principles: Log Analyst, v. 10, no. 1, p. 3-11.
1969, Pulsed nuclear magnetic resonance studies of porosity, movable fluid, and permeability of sandstones: Journal of Petroleum Technology, v. 21, no. 6, p. 775-786.

Timur, Aytekin, Hempkins, W. B., and Massey, G. R., 1971, Analysis of sidewall samples by nuclear magnetic resonance methods: Society of Professional Well Log Analysts Annual Logging Symposium, 12th, Dallas, Tex., 1971, Transactions, p. T1-T21.

Wyman, R. E., 1962, Nuclear magnetism log field test results: Society of Professional Well Log Analysts Annual Logging Symposium, 3d, Houston, Tex., 1962, Transactions, 14 p.

\section{OIL SHALE}

Bardsley, S. R., and Algermissen, S. T., 1965, Evaluating oil shale by log analysis: Journal of Petroleum Technology, v. 15 , no. 1, p. $81-84$.

Chancellor, R. E., Barksdale, W. L., and Dolezal, George, Jr., 1974, Occurrence of oil and gas in the Tertiary system, Rio Blanco Unit, Rio Blanco County, Colorado, in Guidebook to energy resources of the Piceance basin, Colorado: Rocky Mountain Association of Geologists, p. 225234.

Robb, W. A., and Smith, J. W., 1974, Mineral profile of oil shales in Colorado core hole no. 1, Piceance Creek basin, Colorado, in Guidebook to energy resources of the Piceance basin, Colorado: Denver, Rocky Mountain Association of Geologists, p. 91-100.

Weeks, J. B., and others, 1974, Simulated effects of oil-shale development on the hydrology of Piceance basin, Colorado: U.S. Geological Survey Professional Paper 908, 84 p.

Weeks, J. B., and Welder, F. A., 1974, Hydrologic and geophysical data from the Piceance basin, Colorado: Colorado Water Resources Basic-Data Release no. 35, 121 p.

Wolff, R. G., and others, 1974, Tectonic stress determination, northern Piceance Creek basin, Colorado, in Guidebook to energy resources of the Piceance basin, Colorado: Denver, Rocky Mountain Association of Geologists, p. 193198.

\section{PERMAFROST}

Brown, Jerry, and Gray, Shelton, 1968, Geophysical aspects of permafrost: U.S. Army Material Command, Terrestrial Sciences Center, Cold Regions Research and Engineering Laboratory Internal Report 60, $50 \mathrm{p}$.

Desai, K. P., and Moore, E. J., 1967, Well log interpretation in permafrost: Society of Professional Well Log Analysts Annual Logging Symposium, 8th, Denver, Colo., 1967, Transactions p. N1-N27.

Hobson, G. D., Beck, A. E., and Findlay, D. C., 1966, Notes on geophysical logs and borehole temperature measurements from the Muskox drilling project, in Drilling for scientific purposes-International Upper Mantle Symposium, Ottawa, 1965, Report: Geological Survey of Canada Paper 66-13, p. 108-122.

Howell, E. P., Seth, M. S., and Perkins, T. K., 1972, Temperature calculations for wells which are completed through permafrost: Society of Petroleum Engineers of the American Institute of Mining, Metallurgical, and Petroleum Engineers Paper SPE 3969, 12 p. 
Nakano, Yoshisuke, and Arnold, Robert, 1973, Acoustic properties of frozen Ottawa sand: Water Resources Research, v. 9, no. 1, p. 178-184.

Osterkamp, T. E., and Payne, M. W., 1981, Estimates of permafrost thickness from well logs in northern Alaska: Cold Regions Science and Technology, v. 5, no. 1, p. 13-27.

Pollard, D. E., and Nash, R. G., 1971, Observations on permafrost logging in the Canadian Artic: Canadian Well Logging Society Journal, v. 4, no. 1, p. 34-84.

\section{PERMEABILITY}

Bamber, C. L., and Evans, J. R., Jr., 1967, $\phi-k$ Log (permeability definition from acoustic amplitude and porosity logs): Society of Petroleum Engineers of the American Institute of Mining, Metallurgical, and Petroleum Engineers Paper SPE 1971, $12 \mathrm{p}$.

Bredehoeft, J. D., 1964, Variation of permeability in the Tensleep Sandstone in the Bighorn basin, Wyoming, as interpreted from core analyses and geophysical logs, in Geological Survey Research 1964: U.S. Geological Survey Professional Paper 501-D, p. 166-D170.

Burns, W. A., Jr., 1968, New single-well test determines vertical permeability: Society of Petroleum Engineers of the American Institute of Mining, Metallurgical, and Petroleum Engineers Paper SPE 2152, 12 p.

Coates, G. R., and Dumanoir, J. L., 1974, A new approach to improved log-derived permeability: Log Analyst, v. 15, no. 1 , p. $17-31$.

Croft, M. G., 1971, A method of calculating permeability from electric logs, in Geological Survey Research 1971: U.S. Geological Survey Professional Paper 750-B, p. B265B269.

Gaur, R. S., and Singh, Inderjit, 1965, Relationship between permeability and gamma ray intensity for the Oglicene sand of an Indian field: Oil and Natural Gas Commission of India Bulletin, v. 2, no. 1, p. 74-77.

Hodson, G. M., Fertl, W. H., and Hammack, G. W., 1975, New log data give better North Sea well completions: World Oil, v. 181, no. 4, p. 60-65.

Schimschal, Ulrich, 1981, Logging hydraulic conductivity during injection testing in fractured dolomites: Log Analyst, v. 22 , no. 6 , p. 7-12.

Seevers, D. 0., 1966, A nuclear magnetic method for determining the permeability of sandstone: Society of Professional Well Log Analysts Annual Logging Symposium, 7th, Tulsa, Okla., 1966, Transactions, p. L1-L14.

Stephens, D. R., and Lin, W., 1978, Relationships of permeability, $\mathrm{k}$, porosity, $\eta$, and formation factor, F: Lawrence Livermore Laboratory, issued by the U.S. Department of Commerce, National Technical Information Service, Report UCRL-80856, 13 p.

Timur, Aytekin, 1968, An investigation of permeability, porosity, and residual water saturation relationships: Society of Professional Well Log Analysts Annual Logging Symposium, 9th, New Orleans, La., 1968, Transactions, p. J1J18.

\section{PETROLEUM PRODUCTION}

Barlai, Zoltan, 1970, Some principal questions of well logging evaluation of hydrocarbon-bearing sandstones with a high silt/and clay/content_Experience gained by the field application of a new method: Society of Professional Well Log Analysts Annual Logging Symposium, 11th, Los Angeles, Calif., 1970, Transactions, p. 01-064.

Cahill, Jerry, 1966, Use of the drill pipe electric log: Society of Professional Well Log Analysts Annual Logging Symposium, 7th, Tulsa, Okla., 1966, Transactions, p. K1-K18.

Chilingar, G. V., Mannon, R. W., and Rieke, H. H., III, eds., 1972, Oil and gas production from carbonate rocks: New York, American Elsevier Publishing Co., 408 p.

Connolly, E. T., 1965, Resume and current status of the use of logs in production: Society of Professional Well Log Analysts Annual Logging Symposium, 6th, Dallas, Tex., 1965, Transactions, v. 1, p. L1-L78.

Fertl, W. H., and Timko, D. J., 1970, Distinction of oil and gas in clean and shaly sands as derived from well logs: Society of Professional Well Log Analysts Annual Logging Symposium, 11th, Los Angeles, Calif., 1970, Transactions, p. I1-I20.

Glanville, C. R., 1970, Log interpretation of thinly-bedded, oilproductive sands with unusually low resistivities: Society of Professional Well Log Analysts Annual Logging Symposium, 11th, Los Angeles, Calif., 1970, Transactions, p. M1-M27.

Hossin, A., and others, 1970, Application to the Hassi-Messaoud Cambrian reservoir of a new quantitative interpretation method for shaly sands: Society of Professional Well Log Analysts Annual Logging Symposium, 11th, Los Angeles, Calif., 1970, Transactions, p. H1-H28.

Meunier, D., Tixier, M. P., and Bonnet, J. L., 1971, The production combination tool-A new system for production monitoring: Journal of Petroleum Technology, v. 23, no. 5, p. 603-613.

Raymer, L. L., and Morris, R. L., 1964, A new logging program for cased-hole recompletion: Society of Professional Well Log Analysts Annual Logging Symposium, 5th, Midland, Tex., 1964, Transactions, p. G1-G14.

Schaller, H. E., 1970, Defining oil and water entries in production wells in the Permian basin: Southwest Petroleum Short Course Association Annual Meeting, 17th, Lubbock, Tex., 1970, Proceedings, p. 7-13.

Wade, R. T., and others, 1965, Production logging-The key to optimum well performance: Journal of Petroluem Technology, v. 17, no. 2, p. 137-144.

Wichmann, P. A., Hopkinson, E. C., and Youmans, A. H., 1967, Advances in nuclear production logging: Society of Professional Well Log Analysts Annual Logging Symposium, 8th, Denver, Colo., 1967, Transactions, p. T1T10.

Wood, Brian, and Campbell, Ray, 1974, Gas well completion evaluation with the production combination tool: Society of Professional Well Log Analysts European Symposium, 3d, London, England, 1974, Transactions, p. K1-K13. 


\section{POROSITY}

Barlai, Zoltan, 1970, Well logging parameters of hydrocarbonbearing sandstones composed of sand, silt, and shaleEvaluation of water saturation, porosity, and grain-size distribution: Log Analyst, v. 11, no. 2, p. 3-22.

Brown, A. A., and Bowers, Brian, 1958, Porosity determinations from neutron logs: Petroleum Engineer, v. 30, no. 5, p. B30-B34.

Burke, J. A., Campbell, R. L., Jr., and Schmidt, A. W., 1969, The litho-porosity cross plot-A new concept for determining porosity and lithology from logging methods [abs.]: Society of Professional Well Log Analysts Annual Logging Symposium, 10th, Houston, Tex., 1969, Transactions, p. Y1.

Erchul, R. A., 1972, The use of electrical resistivity to determine porosity of marine sediments [University of Rhode Island, $\mathrm{Ph}$. D. dissertation]: University Microfilms, International, Publication no. 72-22372, 127 p.

Evans, H. B., 1965, GRAPE-A device for continuous determination of material density and porosity: Society of Professional Well Log Analysts Annual Logging Symposium, 6th, Dallas, Tex., 1965, Transactions, p. B1-B25.

Fertl, W. H., 1978, Knowing basic reservoir parameters first step in log analysis: Oil and Gas Journal, v. 76, no. 21, p. 98-118.

Fertl, W. H., and Wichmann, P. A., 1977, Open hole porosity logs can be used in cased holes: Oil and Gas Journal, v. 75 , no. 14 , p. 84-86.

1977, Porosity can be determined in cased well bores: Petroleum Engineer, v. 49, no. 5, p. 13-137.

Freeman, Den, and Osoba, J. S., 1979, Porosity determined from neutron, density, and sonic logs in western tight gas sands: U.S. Department of Energy Annual Symposium on Enhanced Oil and Gas Recovery, and Improved Drilling Techniques, 5th, Tulsa, Okla., 1979, Proceedings, v. 1, p. L2/1-L2/9.

Glanville, C. R., 1970, Log interpretations of gas sands from multiple-porosity and resistivity logging programs: Log Analyst, v. 11, no. 4, p. 3-11.

Harms, J. C., and Choquette, P. W., 1965, Geologic evaluation of a gamma-ray porosity device: Society of Professional Well Log Analysts Annual Logging Symposium, 6th, Dallas, Tex., 1965, Transactions, p. C1-C37.

Husten, P. F., and Anton, Heimo, 1981, The porosity surface concept: Erdoel-Erdgas Zeitschrift, v. 97, no. 6, p. 218220.

Jenkins, R. E., 1966, Accuracy of porosity determinations: Log Analyst, v. 7 , no. 2, p. $29-34$.

Khanin, A. A., and Burova, E. G., 1964, Rock permeability as a function of pore space structure: Razvedka i Okhrana Nedr, v. 30, no. 12, p. 22-27; and Glen Ridge, N. J., Associated Technical Services, Inc., p. 1-6.

Lang, W. H., Jr., 1973, Porosity-resistivity cross-plotting: Log Analyst, v. 14, no. 1, p. 16-20.

Lucia, F. J., 1981, Petrophysical parameters estimated from visual descriptions of carbonate rocks-A field classification of carbonate pore space: Society of Petroleum Engineers of the American Institute of Mining, Metallurgical, and Petroleum Engineers Paper SPE 10073, 9 p.
Mercier, V. J., and Redford, W. H., 1957, New calibration and conversion techniques for radioactivity logs: Journal of Petroleum Technology, v. 9, no. 9, p. 11-15.

Mikaelyan, S. S., 1959, The formation factor as a function of the porosity: Geologiya Nefti i Gaza, v. 3, no. 7, p. 39-44; and Glen Ridge, N.J., Associated Technical Services, Inc., p. 1-7.

Morris, R. L., and Biggs, W. P., 1967, Using log-derived values of water saturation and porosity: Society of Professional Well Log Analysts Annual Logging Symposium, 8th, Denver, Colo., 1967, Transactions, p. X1-X26.

Patchett, J. G., and Coalson, E. B., 1979, The determination of porosity in sandstones and shaly sandstones, pt 1Quality control: Log Analyst, v. 20, no. 6, p. 3-12.

Porter, C. R., and Carothers, J. E., 1970, Formation factorporosity relation derived from well log data: Society of Professional Well Log Analysts Annual Logging Symposium, 11th, Los Angeles, Calif., 1970, Transactions, p. A1-A18.

Ransom, R. C., 1977, Methods based on density and neutron well-logging responses to distinguish characteristics of shaly sandstone reservoir rock: Log Analyst, v. 18, no. 3, p. $47-62$.

Raymer, L. L., and Biggs, W. P., 1963, Matrix characteristics defined by porosity computations: Society of Professional Well Log Analysts Annual Logging Symposium, 4th, Oklahoma City, Okla., 1963, Transactions, p. X1-X21.

Russell, J. H., and Bishop, B. O., 1954, Quantitative evaluation of rock porosities by neutron-neutron method: Petroleum Engineer, v. 26, no. 4, p. B76, B78-80, B82, B84, B86.

Savre, W. C., and Burke, J. A., 1963, Determination of true porosity and mineral composition in complex lithologies with the use of sonic, neutron, and density surveys: Society of Professional Well Log Analysts Annual Logging Symposium, 4th, Oklahoma City, Okla., 1963, Transactions, p. XI1-XI35.

Sherman, Harold, and Locke, Stanley, 1975, Effect of porosity on depth investigation of neutron and density sondes: Society of Petroleum Engineers of the American Institute of Mining, Metallurgical, and Petroleum Engineers Paper SPE 5510, $12 \mathrm{p}$.

Stetyukha, E. I., Pivovarov, V. T., and Lyshko, N. A., 1961, Relation between density, unit weight, and porosity of rocks: Izvestiya Vysshikh Uchebnykh Zavedenij, Neft' i Gaz, v. 4, no. 11, 23-27; and Glen Ridge, N.J., Associated Technical Services, Inc., p. 1-6.

Tittman, Jay, 1955, Moderation of neutrons in $\mathrm{SiO}_{2}$ and $\mathrm{CaCO}_{3}$ : Journal of Applied Physics, v. 26, no. 4, p. 394398.

Tixier, M. P., 1958, Porosity balance verifies water saturation determined from logs: Journal of Petroleum Technology, v. 10 , no. 7 , p. 161-169.

Towle, Guy, 1962, an analysis of the formation resistivity factor-porosity relationship of some assumed pore geometries: Society of Professional Well Log Analysts Annual Logging Symposium, 3d, Houston, Tex., 1962, Transactions, $29 \mathrm{p}$.

Traugott, M. O., 1970, Log evaluation of a heterogeneous carbonate reservoir, Cato San Andres field: Society of Professional Well Log Analysts Annual Logging Symposium, 11th, Los Angeles, Calif., 1970, Transactions, p. E1-E8. 
Zoeller, W. A., 1966, Dual porosity logging-A means to better evaluation of porosity and lithology in the Permian Basin: Log Analyst, v. 6, no. 5, p. 50-59.

\section{PRESSURE MEASUREMENTS}

Blakeman, E. R., 1965, Dimensionless time function tables for pressure build-up analysis: Log Analyst, v. 6, no. 3, p. $21-36$.

Boatman, W. A., Jr., 1967, Measuring and using shale density to aid in drilling wells in high-pressure areas: Journal of Petroleum Technology, v. 19, no. 11, p. 1423-1429.

Campbell, Ray, 1974, Overpressure detection using sonicdensity: Society of Professional Well Log Analysts European Symposium, 3d, London, England, 1974, Transactions, p. T1-T8.

Fertl, W. H., and Timko, D. J., 1972, How downhole temperatures affect drilling pressures: World Oil, v. 175, no. 2, p. $36-38,66$.

Groult, J., Reiss, L. H., and Montadert, L., 1965, Reservoir inhomogeneities deduced from outcrop observations and production logging: Society of Petroleum Engineers of the American Institute of Mining, Metallurgical, and Petroleum Engineers Paper SPE 1279, 26 p.

Hottmann, C. E., and Johnson, R. K., 1965, Estimation of formation pressures from log-derived shale properties: Journal of Petroleum Technology, v. 17, no. 6, p. 717-722.

Lauletta, J. F., Whittaker, A. H., and Penny, S. J., 1974, The formation balance gradient: Society of Professional Well Log Analysts European Symposium, 3d, London, England, 1974, Transactions, p. P1-P20.

Olson, C. C., 1967, Technical advancement four decades of D.S.T. [drill stem testing]: Society of Professional Well Log Analysts Annual Logging Symposium, 8th, Denver, Colo., 1967, Transactions, p. M1-M11.

Pirson, S. J., 1962, Petrophysical interpretation of Formation Tester pressure build-up records: Society of Professional Well Log Analysts Annual Logging Symposium, 3d, Houston, Tex., 1962, Transactions, 14, p.

Schlumberger Well Surveying Corporation, 1962, Gradiomanometer tool: Houston, Tex., Report 3, 14 p.

Timko, D. J., 1965, Practical applications of log calculated pressures as an aid to solving drilling problems: Log Analyst, v. 6, no. 3, p. 37-54.

Wallace, W. E., 1965, Abnormal subsurface pressures measured from conductivity or resistivity logs: Society of Professional Well Log Analysts Annual Logging Symposium, 6th, Dallas, Tex., 1965, Transactions, p. I1-I13.

1965, Application of electric log measured pressures to drilling problems and a new simplified chart for well site pressure computation: Log Analyst, v. 6, no. 4, p. 4-10.

Wichmann, P. A., 1974, A review of the use of well logs to abnormal pressure: Society of Professional Well Log Analysts European Symposium, 3d, London, England, 1974, Transactions, p. S1-S15.

\section{PROCRAMS FOR WELL LOG ANALYSES FOR HAND-HELD CALCULATORS}

Bateman, R. M., and Konen, C. E., 1977, The log analyst and the programmable pocket calculator: Log Analyst, v. 18 , no. 5 , p. $3-11$.
1977, The log analyst and the programmable pocket calculator, pt. II-Crossplot porosity and water saturation: Log Analyst, v. 18, no. 6, p. 3-11.

1977, Wellsite log analysis and the programmable pocket calculator: Society of Professional Well Log Analysts Annual Logging Symposium, 18th, Houston, Tex., 1977, Transactions, p. B1-B35.

1978, The log analyst and the programmable pocket calculator, pt. III-Dipmeter computation: Log Analyst, v. 19, no. 1, p. 3-9.

1978, The log analyst and the programmable pocket calculator, pt. IV-Dual induction-Laterolog 8: Log Analyst, v. 19, no. 3, p. 3-7.

1978, The log analyst and the programmable pocket calculator, pt. $V-R_{t}$ and $d_{i}$ from the dual laterolog $-R_{x o}$ : Log Analyst, v. 19, no. 4, p. 11-15.

1979, The log analyst and the programmable pocket calculator, pt. VI-Finding true stratigraphic thickness and true vertical thickness of dipping beds cut by directional wells: Log Analyst, v. 20, no. 2, p. 3-27.

Cooley, B. B., 1979, PPC data entry simplification and standardization: Log Analyst, v. 20, no. 2, p. 33.

Gobran, B. D., Brown, S. L., and Sanyal, S. K., 1981, A handheld calculator program for estimating water salinity from well logs: Log Analyst, v. 22, no. 2, p. 25-36.

Gobran, B. D., and others, 1980, A comprehensive mathematical approach and a hand-held calculator program for analysis of shaly gas sands: Log Analyst, v. 21, no. 5, p. 11-21.

Schoonover, L. G., and Fertl, W. H., 1979, Porosity and water saturation using handheld calculators: Oil and Gas Journal, v. 77 , no. 31 , p. $170-172$.

1979, Estimate $R_{w a}$ and water saturation with handheld calculator programs: Oil and Gas Journal, v. 77, no. 29, p. $67-68$.

Smith, S. W., and Keen, Douglass, 1979, A simplified true vertical thickness (TVT) calculation using a programmable pocket calculator: Log Analyst, v. 20, no. 2, p. 28-32.

Souder, W. W., and Williams, J. S., 1979, Interactive calculators can aid wellsite log analysis: Oil and Gas Journal, v. 77 , no. 48 , p. $69-70,75,79$.

Thompson, K. D., 1978, Well log interpretation of shaly sands with the programmable calculator: Society of Professional Well Log Analysts Annual Logging Symposium, 19th, El Paso, Tex., 1978, Transactions, p. X1-X27.

Tsang, P. B., 1979, Addendum to The log analyst and the programmable pocket calculator by $R$. M. Bateman and C. E. Konen, 1977, (in The Log Analyst, v. 18, no. 5, p. 3-11): Log Analyst, v. 20, no. 2, p. 7-27.

Turner, W. J., 1980, Hand-held calculator programs for frequently used formulas, pt. 8-Directional well surveysRadius of curvature methods: Petroleum Engineer International, v. 51 , no. 13 , p. $102-114$.

Wu, C. H., and Krug, Jack, 1978, Density-neutron crossplot analysis for shaly gas sands using hand-carried calculators: Log Analyst, v. 19, no. 4, p. 3-10.

1979, Shaly gas-sand analysis using hand-carried calculators: Log Analyst, v. 20, no. 3, p. 20-25.

\section{PULSED NEUTRON}

Allen, L. S., and Mills, W. R., Jr., 1975, Measurements of the thermal neutron absorption cross section of rock samples by a pulsed source method: Log Analyst, v. 16, no. 1 , p. 10-13. 
Allen, L. S., Mills, W. R, Jr., and Caldwell, R. L., 1965, The effects of fluid invasion in pulsed neutron logging: Society of Professional Well Log Analysts Annual Logging Symposium, 6th, Dallas, Tex., 1965, Transactions, p. H1-H8.

Al-Saif, A. S., and others, 1975, Analysis of pulsed-neutron decay-time logs in acidized carbonate formations: Society of Petroleum Engineers Journal, v. 15, no. 6, p. 453-466.

Barton, Wayne, and Flynn, J. M., 1979, Applications of the carbon/oxygen $\log$ in Johnson (Glorieta) field: Society of Petroleum Engineers of the American Institute of Mining, Metallurgical, and Petroleum Engineers Paper SPE 8453, 8 p.

Charlson, G. S., Bilhartz, H. L., Jr., and Stalkup, F. I., 1978, Use of time-lapse logging techniques in evaluating the Willard unit $\mathrm{CO}_{2}$ flood mini-test: Society of Petroleum Engineers of the American Institute of Mining, Metallurgical, and Petroleum Engineers Paper SPE 7049, 10 p.

DeVries, M. R., and Fertl, W. H., 1977, Time-lapse cased hole reservoir evaluation based on the dual-detector neutron lifetime log-The Ches II approach: Society of Professional Well Log Analysts Annual Logging Symposium, 18th, Houston, Tex., 1977, Transactions, p. V1-V15.

Dewan, J. T., and others, 1973, Thermal neutron decay logging using dual detection: Log Analyst, v. 14, no. 5, p. 13-25.

Engelke, C. P., and Hilchie, D. W., 1971, A new qualitative permeability indicator: Society of Professional Well Log Analysts Annual Logging Symposium, 12th, Dallas, Tex., 1971, Transactions, p. M1-M10.

Hamp, T. A., and Edgson, J. J., 1979, Improved techniques in pulsed neutron evaluation in the Nipisi Gilwood " $A$ " formation: Journal of Canadian Petroleum Technology, $v$. 18 , no. 4 , p. $69-76$.

Hilchie, D. W., 1970, Neutron lifetime log interpretation in in shaly sands: Houston, Tex., Dresser Atlas, $17 \mathrm{p}$.

Hilchie, D. W., and others, 1968, Some aspects of pulsed neutron logging: Society of Professional Well Log Analysts Annual Logging Symposium, 9th, New Orleans, La., 1968, Transactions, p. Q1-Q26.

Hoffman, G. W., 1971, Recognition of potentially producible oil and gas zones in cased holes with neutron lifetime logs: Society of Professional Well Log Analysts Annual Logging Symposium, 12th, Dallas, Tex., 1971, Transactions, p. V1V10.

Hoyer, W. A., and others, eds., 1976, Pulsed neutron logging (reprint volume): Houston, Tex., Society of Professional Well Log Analysts, 347 p.

Humphreys, D. R., and others, 1980, Uranium logging by prompt fission neutron technique: Sandia Laboratories, issued by the U.S. Department of Commerce, National Technical Information Service, Report CONF-801111-16, 5 p.

Itoh, Toshinobu, 1971, Pulse neutron well-logging techniques, in Geophysical exploration, drilling and production: World Petroleum Congress, 8th, Proceedings, 1971, v. 3, p. 3744.

Jensen, D. H., and others, 1980, Pulsed neutron gamma ray logging for minerals associated with uranium: Sandia $\mathrm{Na}$ tional Laboratory, issued by the U.S. Department of Commerce, National Technical Information Service, Report CONF-801111-14, 6 p.
Lawrence, T. D., 1979, Continuous carbon/oxygen log interpretation techniques: Society of Petroleum Engineers of the American Institute of Mining, Metallurgical, and Petroleum Engineers Paper SPE 8366, 12 p.

Lawson, B. L. and Cook, C. F., 1970, A theoretical and laboratory evaluation of carbon logging, pt. 2-Theoretical evaluation of oxygen interference: Society of Professional Well Log Analysts Annual Logging Symposium, 11th, Los Angeles, Calif., 1970, Transactions, p. B1-B12.

Mills, W. R., Jr., and others, 1965, Pulsed-neutron experiments in a borehole model: Nuclear Science and Engineering, v. 21, p. $346-356$.

Nelligan, W. B., and Antkiw, Stephen, 1979, Accurate thermal-neutron decay time measurements using the far detector of the dual-spacing TDT-A laboratory study: Society of Petroleum Engineers of the American Institute of Mining, Metallurgical, and Petroleum Engineers Annual Fall Technical Conference and Exhibition, 51st, New Orleans, La., 1979, Transactions, p. 59-66.

Randal, R. R., Fertl, W. H., and Hopkinson, E. C., 1981, Time derived sigma for pulsed neutron capture logging: Society of Petroleum Engineers of the American Institute of Mining, Metallurgical, and Petroleum Engineers Paper SPE 9614, 6 p.

Randal, R. R. Hopkinson, E. C. and Youmans, A. H., 1978, A study of the effects of diffusion on pulsed neutron capture logs: Journal of Petroleum Technology, v. 30, no. 12, p. 1788-1794.

Richardson, J. E., 1971, A method of calculating the capture cross section of oil for use with pulsed neutron capture logs: Society of Professional Well Log Analysts Annual Logging Symposium, 12th, Dallas, Tex., 1971, Transactions, p. I1-I17.

Smith T. J., and Stieber, S. J., 1974, Determination of residual oil saturation with pulsed neutron logs-A field experiment: Society of Petroleum Engineers of the American Institute of Mining, Metallurgical, and Petroleum Engineers Paper SPE 5120, 10 p.

Threadgold, Philip, 1971, Interpretation of thermal neutron die away logs-Some useful relationships: Society of Professional Well Log Analysts Annual Logging Symposium, 12th, Dallas, Tex., 1971, Transactions, p. L1-L16.

Tittman, Jay, and Nelligan, W. B., 1959, Laboratory studies of a pulsed neutron source technique in well logging: Society of Petroleum Engineers of the American Institute of Mining, Metallurgical, and Petroleum Engineers Rocky Mountain Petroleum Section Meeting, Casper, Wyoming, 1959, Paper 1227-G, 11 p.

Veazey, M. J., and Carlton, A. W., 1976, New logging approach to old wells: Petroleum Engineer, v. 48, no. 8, p. $30-42$.

Youmans, A. H., 1977, Carbon/oxygen log defines cased-hole oil saturation: World Oil, v. 164, no. 2, p. 39-42.

Youmans, A. H., and Hopkinson, E. C., 1975, The influence of instrument design on neutron lifetime measurements: Society of Petroleum Engineers Journal, v. 15, no. 2, p. 161-168.

\section{RADAR}

Geophysical Survey Systems, 1974, Continuous subsurface profiling by impulse radar: Hudson, N.H., 20 p. 
Holser, W. T., and others, 1971, Radar logging of a salt dome [abs]: Society of Professional Well Log Analysts Annual Logging Symposium, 12th,, Dallas, Tex., 1971, Transactions, p. U1.

\section{REDOX LOCGING}

Karaoguz, Dogu, Helander, D. P., and Kemp, M. K., 1970, An experimental study of redox logging: Log Analyst, v. 11 , no. 3, p. 8-16.

Machan, Rudolph, and Ott, Jorg, 1972, Problems and methods of continuous in situ measurements of redox potentials in marine sediments: Limnology and Oceanography, v. 17, no. 4, p. 622-624.

Pirson, S. J., 1968, Redox log interprets reservoir potential: Oil and Gas Journal, v. 66, no. 31, p. 69-75.

1969, Environmental logging and mapping in the search for minerals: Society of Professional Well Log Analysts Annual Logging Symposium, 10th, Houston, Tex., 1969, Transactions, p. I1-I47.

Roy, K. K., and Baksi, S. S., 1977, Model studies on redox logging for minerals: Journal of Geophysics, v. 42, p. 521533.

\section{RESISTIVITY}

Alger, R. P., 1966, Interpretation of electric logs in fresh water wells in unconsolidated formations: Society of Professional Well Log Analysts Annual Logging Symposium, 7th, Tulsa, Okla., 1966, Transactions, p. CC1-CC25.

Beckmann, H., and Demiray, G., 1975, The nanolog, a new way to $\log$ the resistivity of the sea floor: Geophysical Prospecting, v. 24, no. 2, p. 309-316.

Belen'kii, Y. E., Mikhailovskii, V. N., and Svenson, A. N., 1959, A multichannel telemetering device for coordinated geophysical investigation of wells: Geologiya Nefti i Gaza, v. 3, no. 1, p. 52-55, and Glen Ridge, N.J., Associated Technical Services, Inc., 5 p.

Blakeman, E. R., 1962, A method of analyzing electrical logs recorded on a logarithmic scale: Journal of Petroleum Technology, v. 14, no. 8, p. 844-850.

Bradley, J. S., 1980, Fluid and electrical formation conductivity factors calculated for a sperical-grain onion-skin model: Log Analyst, v. 21, no. 1, p. 24-32.

Brown, D. L., 1971, Techniques for quality-for-water interpretations from calibration geophysical logs, Atlantic Coastal area: Ground Water, v. 9, no. 4, p. 25-38.

Croft, M. G., 1971, A method of calculating permeability from electric logs, in Geological Survey Research 1971: U.S. Geological Survey Professional Paper 750-B, p. B265B269.

Daniels, J. J., 1977, Extending the range of investigation of borehole electrical measurements: Society of Professional Well Log Analyst Annual Logging Symposium, 18th, Houston, Tex., 1977, Transactions, p. D1-D18.

Denver Well Logging Society, 1964, Rocky Mountain formation water resistivities: Denver, Colo., Petroleum Information, $117 \mathrm{p}$.

Doll, H. G., 1955, Filtrate invasion in highly permeable sands: Petroleum Engineer, v. 27, no. 1, p. B53-B66.

Doll, H. G., Dumanoir, J. L., and Martin, Maurice, 1960, Suggestions for better electric log combinations and improved interpretations: Geophysics, v. 25, no. 4, p. 854-882.
Doll, H. G., Legrand, J. C., and Stratton, E. F., 1947, True resistivity determination from the electric log-Its application to log analysis: Oil and Gas Journal, v. 46, no. 20, p. 297-310.

Doll, H. G., and Martin, M. 1954, How to use electrical log data to determine maximum producible oil index: Oil and Gas Journal, v. 53, no. 9, p. 120-126.

Dullien, F. A. L., 1975, Prediction of tortuosity factors from pore structure data: American Institute of Chemical Engineering Journal, v. 21, no. 4, p. 820-822.

Erchul, R. A., 1972, The use of electrical resistivity to determine porosity of marine sediments [University of Rhode Island, Ph. D. dissertation]: University Microfilms, International, Publication no. 72-22372, $127 \mathrm{p}$.

Evans, H. B., 1966, Suggested modifications to the Grand Slam suite: World Oil, v. 163, no. 4, p. 99-102.

Fishel, K. W., 1976, Applications of electric logs in Appalachian coal exploration: Geological Society of America Annual Coal Geology Division Symposium, Denver, Colo., 1976, Proceedings, p. 1-18.

George, E. R., 1963, Formation evaluation in wells drilled with inverted emulsion mud compared with wells drilled with water-base mud: Society of Professional Well Log Analysts Annual Logging Symposium, 4th, Oklahoma City, Okla., 1963, Transactions, p. XVI1-XVI49.

Gianzero, S. C., and Rau, R. N., 1977, The effect of sonde position in the hole on responses of resistivity logging tools: Geophysics, v. 42, no. 3, p. 642-654.

Goryunov, I. I., 1960, Study of rock jointing by using data from electrical logging: Geologiya i Geofizika, no. 3, p. 94 102, and Glen Ridge, N.J., Associated Technical Services, Inc., $9 \mathrm{p}$.

Grubb, R. N., Orswell, P. L., and Taylor, J. H., 1976, Borehole measurements of conductivity and dielectric constant in the $300 \mathrm{kHz}$ to $25 \mathrm{MHz}$ frequency range: Radio Science, v. 11, no. 4, p. 275-283.

Guyod, Hubert, 1944, Guyod's electrical well logging: Houston, Tex., Halliburton Co., Welex Division Bulletin A132, 103 p.

1952, Electrical well logging fundamentals: Houston, Tex., Well Instrument Developing Co., 164 p.

1952, Resistivity departure charts: Oil and Gas Journal, v. 50, no. 46, p. 195-198, 210-212.

1954, Electrical well logging: The Science of Petroleum, v. 6, pt. 2,30 p.

1955, Electric analogue of resistivity logging: Geophysics, v. 20, no. 3, p. 615-629.

1957, Electric detective-Investigation of groundwater supplies with electric well logs, pt. 1: Water Well Journal, v. 11 , no. 3., p. $12-13,32,35-36$.

1966, Interpretation of electric and gamma ray logs in water wells: Log Analyst, v. 6, no. 5, p. 29-44.

Guyod, Hubert, and Pranglin, J. A., 1961, Now-Get true resistivities from conventional electric logs: Oil and Gas Journal, v. 59, no. 24, p. 1-6.

Guyod, Hubert, and Wichmann, P. A., 1971, Theoretical notes on the resistivity of shaly sands: Society of Professional Log Analysts Annual Logging Symposium, 12th, Dallas, Tex., 1971, Transactions, p. Y1-Y13.

Haanschoten, G. W., 1977, Logging tool offers greater depth: Oil and Gas Journal, v. 75, no. 2, p. 70-74. 
Haines, B. M., and Emerson, D. W., 1972, Aspects of mud properties in geophysical logging of shallow water bores: Australian Society of Exploration Geophysical Bulletin, v. 3 , no. 3, p. 33-52.

Hansen, H. J., 1967, The electric log-Geophysics contribution to ground water prospecting and evaluation: Maryland Geological Survey Information Circular 4, $11 \mathrm{p}$.

Helander, D. P., and Campbell, J. M., 1966, The effect of pore configuration, pressure, and temperature on rock resistivity: Society of Professional Well Log Analysts Annual Logging Symposium, 7th, Tulsa, Okla., 1966, Transactions, p. W1-W29.

Hilchie, D. W., 1966, An example of quantitative log analysis with little to no invasion: Log Analyst, v. 6, no. 6, p. 24-28.

Housley, R. M., and Oliver, J. R., 1977, Electrical characteristics of igneous Precambrian basement rocks of central North America, in The earth's crust: Geophysical Monographs of the American Geophysical Union, p. 181-195.

Johnson, H. M., and Beyer, R. F., 1962, Further studies in resistivity effects of various mud additives: Society of Professional Well Log Analyst Annual Logging Symposium, 3d, Houston, Tex., 1962, Transactions, p. 1-15.

Johnson National Drillers Journal, 1971, Electric logging helps driller get better wells: v. 43 , no. 1, p. 1-4.

Jones, P. H., and Buford, T. B., 1951, Electric logging applied to ground-water exploration: Geophysics, v. 16, no. 1, p. 115-139.

Keller, G. V., 1964, Compilation of electrical properties from electrical well logs: Quarterly of the Colorado School of Mines, v. 59, no. 4, p. 91-110.

1966, Statistical studies of electrical well logs: Society of Professional Well Log Analysts Annual Logging Symposium, 7th, Tulsa, Okla., 1966, Transactions, p. AA1AA19.

Koithara, Joseph, and Candra, Dinesh, 1977, Field results on the relative performance of laterolog 7 and normal devices: Geophysics, v. 42, no. 7, p. 1478-1483.

Krueger, W. C., Jr., 1968, Depositional environments of sandstones as interpreted from electrical measurements-An introduction: Gulf Coast Association of Geological Societies Transactions, v. 18, p. 226-241.

Kumar, R. M., and Helander, D. P., 1973, The effect of pressure on aqueous sodium chloride solution resistivity for varying temperatures and concentrations: Log Analyst, v. 14 , no. 4 , p. $12-17$.

Lishman, J. R., 1961, Salt bed identification from unfocused resistivity logs: Geophysics, v. 26 , no. 3 , p. $320-341$.

McFadzean, T. B., 1971, An empirical look at bed boundaries in sand shale sequences: Canadian Well Logging Society Journal, v. 4, no. 1, p. 7-23.

McNeill, J. D., 1980, Electrical conductivity of soils and rocks: Mississauga, Ontario, Canada, Geonies Limited, Technical Note no. TN-5, $22 \mathrm{p}$.

Milliard, F. S., and King, R. B., 1962, Well log evaluation of the Trenton-Black River carbonate in the Scipio-Albion Trend: Society of Professional Well Log Analysts Annual Logging Symposium, 3d, Houston, Tex., 1962, Transactions, p. 1-8.
Moussie, C., and Cazal, A., 1973, Utilisation statisique des resultats des sondages et disgraphies electriques dans l'evaluation de la mineralisation des eaux spiterraomes (French): Revue de L'Institut Francais du Petrole, v. 28, no. 4 , p. $563-586$.

Oduolowu, O. A., 1977, A case study of the determination of connate water resistivity, $R_{w}$, by repeat logging, in the Powder River basin, Wyoming: Log Analyst, v. 18, no. 6, p. 27-31.

Olhoeft, G. R., and Scott, J. H., 1980, Nonlinear complex resistivity logging: Society of Professional Well Log Analysts Annual Logging Symposium, 21st, Lafayette, La., 1980, Transactions, p. T1-T18.

Osborn, C. K., 1974, Formation evaluation through combined use of core analysis and electrical resistivity logs: Society of Petroleum Engineers of the American Institute of Mining, Metallurgical, and Petroleum Engineers Paper SPE 4809,9 p.

Oshry, H. L., and Zenor, H. M., 1962, Modification of the induction log geometric factor due to propagation effects: Society of Professional Well Log Analysts Annual Logging Symposium, 3d, Houston, Tex., 1962, Transactions, 14 p.

Overton, H. L., 1970, Resistivity logging from shale slurries: Society of Professional Well Log Analysts Annual Logging Symposium, 11th, Los Angeles, Calif., 1970, Transactions, p. $\mathrm{C} 1-\mathrm{C} 20$.

Overton, H. L., and Zeid, M. C., 1971, A progress report on shale electric log: Society of Professional Well Log Analyst Annual Logging Symposium, 3d, Houston, Tex., 1962, Transactions, p. 1-25.

Ozcandarli, T. D., 1969, The use of entire apparent resistivity curves for interpretation of normal resistivity logs: Golden, Colorado School of Mines, M.S. thesis T-1255, 104 p.

Peterson, F. L., and Lao, Chester, 1970, Electric well logging of Hawaiian basaltic aquifers: Ground Water, v. 8, no. 2, p. 11-18.

Piwinskii, A. J., and Weed, H. C., 1976, A study of rock-solution interaction and its effect on Archie's Law: Institute of Electrical and Electronics Engineers, Geoscience Electronics Transactions, v. GE-14, no. 4, p. 221-223.

Poupon, Andre, Loy, M. E., and Tixier, M. P., 1954, A contribution to electrical $\log$ interpretations in shaly sands: Journal of Petroleum Technology, v. 6, no. 6, p. 27-34.

Pranglin, J. A., 1957, Departure curves and electrode factors for the determination of true formation resistivity from electric logs obtained with roller type electrodes in air drilled boreholes not containing fluid: U.S. Atomic Energy Commission, issued by the U.S. Department of Commerce, National Technical Information Service Report RME-3147, 13 p.

Ransom, R. C., 1974, The bulk volume water concept of resistivity well $\log$ interpretation, a theory based on a new reservoir rock resistivity model: Log Analyst, v. 15, no. 1, p. 3-16.

Rodriquez, A. R., and Pirson, S. J., 1968, The continuous dipmeter as a tool for studies in directional sedimentation and directional tectonics: Society of Professional Well Log Analysts Annual Logging Symposium, 9th, New Orleans, La., 1968, Transactions, G1-G25.

Roy, Amalendu, 1975, New results in resistivity well logging: Geophysical Prospecting, v. 23, no. 3, p. 426-448. 
1982, Focused resistivity logs, in Fitch, A. A., ed., Developments in geophysical exploration methods-3: London, England, Elsevier Applied Science Publishers, p. 6194.

Roy, Amalendu, and Apparao, A., 1976, Laboratory results in resistivity logging: Geophysical Prospecting, v. 24, no. 1, p. 123-140.

Rudman, A. J., 1982, Interrelationship of resistivity and velocity logs, in Fitch, A. A., ed., Developments in geophysical exploration methods -3: London, England, Elsevier Applied Seience Publishers, p. 33-59.

Rumiantseva, N. N., 1965, The effect of clay content on the relative resistivity of sandy-argillaceous rocks: Neftegazovaya Geologiya i Geofizika, no. 6, p. 40-44.

Runge, R. J., and Hill, D. O., 1971, The role of anisotrophy in ULSEL: Society of Professional Well Log Analysts Annual Logging Symposium, 12th, Dallas, Tex., 1971, Transactions, p. J1-J23.

Runge, R. J., Worthington, A. E., and Lucas, D. R., 1969 , Ultra-long spaced electric log (ULSEL): Log Analyst, v. 10 , no. 5 , p. $20-30$.

Sanyal, S. K., Marsden, S. S., Jr., and Ramey, H. J., Jr., 1973, The effect of temperature on electrical resistivity of porous media: Log Analyst, v. 24, no. 2, p. 10-24.

Schoeppel, R. J., and Thrasher, J. E., 1966, Laboratory study of induced polarization in sandstone rocks with varying salinity and shalyness: Society of Professional Well Log Analysts Annual Logging Symposium, 7th, Tulsa, Okla., 1966, Transactions, p. T1-T42.

Schopper, J. R., and Rink, Manfred, 1974, Interface conductivity and its implications to electric logging: Society of Professional Well Log Analysts European Symposium, 3d, London, England, 1974, Transactions, p. M1-M14.

Scott, J. H., and Farstad, A. J., 1977, Electrical resistivity well-logging system with solid-state electronic circuitry: U.S. Geological Survey Open-File Report 77-144, 28 p.

Shamey, L. J., and Adams, W. M., 1971, Interpretation of electrical resistivity logs in a two-zone cylindrically symmetric geometry: Honolulu, University of Hawaii, Water Resources Research Center Technical Report no. 46, 48 p.

1971, Electrical resistivity log interpretation for three cylindrical zone model: Boulder, University of Colorado, Cooperative Institute for Research in Environment Sciences, $10 \mathrm{p}$.

Sorber, H. W., 1966, Some logging and perforating procedures in NW-Germany: Society of Professional Well Log Analysts Annual Logging Symposium, 7th, Tulsa, Okla., 1966, Transactions, p. F1-F19.

Sundberg, Karl, 1980, Effect of impregnating waters on electrical and conductivity of soils and rocks: Log Analyst, v. 21 , no. 5 , p. $19-31$.

Tixier, M. P., Morris, R. L., and Connell, J. G., 1968, Log evaluation of low-resistivity pay sands in the Gulf Coast: Log Analyst, v. 9, no. 6, p. 3-20.

Turcan, A. N., 1962, Estimating water quality from electrical logs, in Geological Survey Research 1962: U.S. Geological Survey Professional Paper 450-C, p. C135-C136.

1966, Calculation of water quality from electrical logsTheory and practice: Louisiana Geological Survey, and Louisiana Department of Public Works Resources Pamphlet 19, 23 p.
Wallace, W. E., 1965, Abnormal subsurface pressures measured from conductivity or resistivity logs: Log Analyst, v. 5 , no. 4 , p. $1-13$.

Waxman, M. H., and Thomas, E. C., 1972, Electrical conductivities in shaly sands, I-The relation between hydrocarbon saturation and resistivity index; II-The temperature coefficient of electrical conductivity: Society of Petroleum Engineers of the American Institute of Mining, Metallurgical, and Petroleum Engineers Paper SPE 4094, 41 p.

Weed, H. C., Piwinskii, A. J., and Keller, P. R., 1976, Time dependent electrical properties of rock-solution systems: Society of Petroleum Engineers of the American Institute of Mining, Metallurgical, and Petroleum Engineers Paper SPE $6609,8 \mathrm{p}$.

Wieland, D. R., Wang, G., and Helander, D. P., 1962, Laboratory resistivity evaluation of lime, gyp, and lignite-lignosulphate muds: Society of Professional Well Log Analysts Annual Logging Symposium, 3d, Houston, Tex., 1962, Transactions, p. 1-25.

Willibrand, A. F., and Mayer, Robert, Jr., 1967, Electrical logging for the engineering geologist: Dallas, Tex., Well Reconnaissance, Inc., 9 p.

Winsauer, W. O., and McCardell, W. M., 1953, Ionic doublelayer conductivity in reservoir rock: American Institute of Mining, Metallurgical, and Petroleum Engineers Transactions, v. 198, p. 129-134.

\section{SALINE WATER PROBLEMS}

Keys, W. S., and MacCary, L. M., 1973, Location and characteristics of the interface between brine and fresh water from geophysical logs of boreholes in the upper Brazos River Basin, Texas: U.S. Geological Survey Professional Paper 809-B, p. B1-B23.

Monkhouse, R. A., and Fleet, M., 1975, A geophysical investigation of saline water in the chalk of the south coast of England: Quarterly Journal of Engineering Geology, v. 8, no. 4, p. 291-302.

Moston, R. P., and Johnson, A. I., 1961, Geophysical exploration of wells as an aid in location of salt-water leakage, Alameda Plain, California, in Geological Survey Research, 1961: U.S. Geological Survey Professional Paper 424-D, p.D262-D264.

\section{SHALE AND CLAY EFFECTS}

Alger, R. P., 1962, Interpretation of the Dakota sandstone of the San Juan Basin: Society of Professional Well Log Analysts Annual Logging Symposium, 3d, Houston, Tex., 1962, Transactions, p. 1-19.

Barlai, Zoltan, 1974, Effects of fine grains and shale laminae on well $\log$ evaluation of the hydrocarbon bearing neogene sandstones in Hungary: Society of Professional Well Log Analysts European Symposium, 3d, London, England, 1974, Transactions, p. I1-I46.

Fertl, W. H., and Frost, Elton, Jr., 1979, Evaluation of shaly clastic reservoir rocks: Society of Petroleum Engineers of the American Institute of Mining, Metallurgical, and Petroleum Engineers Paper SPE 8450, 12 p.

Fons, Lloyd, Johns, Earl, and Mougne, M. L., 1970, New way to evaluate shaly formations: Oil and Gas Journal, v. 68, no. 31, p. 74-77. 
Hill, H. J., Shirley, O. J., and Klein, G. E., 1979, Bound water in shaly sands-Its relation to $Q_{v}$ and other formation properties: Log Analyst, v. 20, no. 3, p. 3-19.

King, E. E., and Fertl, W. H., 1979, Evaluating shale reservoir logs: Oil and Gas Journal, v. 77, no. 13, p. 166-168.

Overton, H. L., and Zeid, M. C., 1971, A progress report on shale electric log: Society Professional Well Log Analysts Annual Logging Symposium, 12th, Dallas, Tex., 1971, Transactions, p. B1-B21.

Thomas, E. C., 1975, The determination of $Q_{v}$ from membrane potential measurements on shaly sands: Society of Petroleum Engineers of the American Institute of Mining, Metallurgical, and Petroleum Engineers Paper SPE 5505, 7 p.

\section{SPONTANEOUS POTENTIAL}

Bogoslovsky, V. A., and Ogilvy, A. A., 1970, Application of geophysical methods for studying the technical status of earth dams: Geophysical Prospecting Supplement, v. 18, no. 4, p. 758-773.

1973, Deformations of natural electric fields near drainage structures: Geophysical Prospecting, v. 21, no. 4, p. 716-723.

1973, Electrometric observations of antifiltrational cementation curtains: Geophysical Prospecting, v. 21, no. 2, p. 296-314.

Doll, H. G., 1948, The S.P. log-Theoretical analysis and principles of interpretation: American Institute of Mining, Metallurgical, and Petroleum Engineers Technical Publication no. 2463, 40 p.

Gondouin, M., and Scala, C., 1957, Streaming potential and the SP log: Society of Petroleum Engineers of the American Institute of Mining, Metallurgical, and Petroleum Engineers Paper 864-G, 20 p.

Gondouin, M., Tixier, M. P., and Simard, G. L., 1957, An experimental study on the influence of the chemical composition of electrolytes on the SP curve: Journal of Petroleum Technology, v. 9, no. 2, p. 58-70.

Guyod, Hubert, 1964, An investigation of factors affecting the SP curve in soft formations: Society of Professional Well Log Analysts Annual Logging Symposium, 5th, Midland, Tex., 1964, Transactions, p. A1-A18.

Haines, B. M., 1978, The detection of water leakage from dams using streaming potentials: Society of Professional Well Log Analysts Annual Logging Symposium, 19th, El Paso, Tex., 1978, Transactions, p. K1-K13.

Haji-Shafie, Manoutcher, 1980, Electric log interpretation of the Sparta Formation, east central Louisiana, in Tanner, W. F., ed., Shorelines, past and present: Annual Symposium on Coastal Sedimentology, 5th, Tallahassee, Fla., 1980, Proceedings, p. 639-692.

Hallenburg, J. K., 1971, A resume of spontaneous potential measurements: Society of Professional Well Log Analysts Annual Logging Symposium, 12th Dallas, Tex., 1971, Transactions, p. H1-H15.

1978, Use of the spontaneous potential curve in a mineral mapping technique: Society of Professional Well Log Analysts Annual Logging Symposium, 19th, El Paso, Tex., 1978, Transactions, p. U1-U12.
Henry, J. D., and Cunningham, W. A., 1962, A new method for determination of formation water resistivity from the spontaneous potential curve: Society of Petroleum Engineers of the American Institute of Mining, Metallurgical, and Petroleum Engineers Paper SPE 437, 6 p.

McCall, C. M., Von Gonten, W. D., and Osoba, J. S., 1971, The effect of hydrocarbons on the SP opposite sands: Society of Professional Well Log Analysts Annual Logging Symposium, 12th, Dallas, Tex., 1971, Transactions, p. C1C20.

Ogilvy, A. A., Ayed, M. A., and Bogoslovsky, V. A., 1968, Geophysical studies of water leakages from reservoirs: European Association of Exploration Geophysicists Meeting, 30th, Salzburg, Germany, 1968, Proceedings p. 36-62.

Overton, H. L., 1970, SP Curve reflects stressed zones: Petroleum Engineer, v. 42, no. 10, p. 76-85.

Paczynski, Bronislaw, 1961, Use of the self-potential for the determination of hydrologic parameters in test pumping: Przeglad Geologiczny, v. 9, no. 4, p. 210-214; and Glen Ridge, N. J., Associated Technical Services, Inc., 8 p.

Pied, Bernard, and Poupon, Andre, 1966, SP base line shifts in Algeria: Society of Professional Well Log Analysts Annual Logging Symposium, 7th, Tulsa, Okla, 1966, Transactions, p. H1-H12.

Pirson, S. J., and Wong, K. S., 1972, The neglected SP curve: Society of Professional Well Log Analysts Annual Logging Symposium, 13th Tulsa, Okla., 1972, Transactions; p. C1C16.

Segesman, F., 1962, New SP correction charts: Geophysics, v. 27 , no. 6 , p. $815-828$.

Segesman, F., and Tixier, M. P., 1959, Some effects of invasionon the SP curve: Journal of Petroleum Technology, v. 11 , no. 6 , p. $138-146$.

Silva, Pedro, and Bassiouni, Zaki, 1981, A new approach to the determination of formation water resistivity from the SP log: Society of Professional Well Log Analysts Annual Logging Symposium, 22d, Mexico City, Mexico, 1981, Transactions, p. G1-G15.

Vonhofv, J. A., 1966, Water quality determination from spontaneous-potential electric log curves: Journal of Hydrology, v. 4, no. 4 p. 341-347.

Wyllie, M. R. J., 1970, A quantitative analysis of the electrochemical component of the SP curve in well logging, Society of Petroleum Engineers of the American Institute of Mining, Metallurgical, and Petroleum Engineers SPE Reprint Series no. 1 [1971], p. 117-126.

\section{STATISTICAL METHODS}

Daniels, J. J., Scott, J. H., and Hite, R. J., 1979, Analysis of borehole geophysical data in an evaporite sequence at Salt Valley, Utah: Society of Professional Well Log Analysts Annual Logging Symposium, 20th, Tulsa, Okla., 1979, Transactions, p. M1-M19.

Hempkins, W. B., 1977, Multivariate statistical approaches in formation evaluation: Society of Professional Well Log Analysts Annual Logging Symposium, 18th, Houston, Tex., 1977, Transactions, p. DD1-DD23.

Heseldin, G. M, 1968, The use of error ratio in least square fitting of data: $\log$ Analyst, v. 9, no. 3, p. 22-25. 
Patchett, J. G., 1977, The use of multiple linear regression analysis to calculate formation water saturation from logs: Society of Professional Well Log Analysts Annual Logging Symposium, 18th, Houston, Tex., 1977, Transactions, p. A1-A20.

\section{STRESS MEASUREMENTS}

Hoskins, E. R., and Oshier, E. H., 1974, A deep hole stress measurement device: South Dakota School of Mines and Technology, issued by the U.S. Department of Commerce, National Technical Information Service, Report AD-783304,142 p.

Keys, W. S., and others, 1979, In situ stress measurements near the San Andreas Fault in Central California: Journal of Geophysical Research, v. 84, no. B4, p. 1583-1591.

Knopoff, Leon, and MacDonald, G. J. F., 1958, Attenuation of small amplitude stress waves in solids: Review of Modern Physics, v. 30, no. 4, p. 1178-1192.

McGarr, A., and Gay, N. C., 1978, State of stress in the earth's crust: Annual Reviews of Earth Planetary Science, v. 6 , p. $405-436$.

TRW Systems Group, 1974, An optical instrument for in-situ stress measurement in rocks: U.S. Department of Commerce, National Technical Information Service, Report AD-783 301, 40 p.

Wolff, R. G., and others, 1974, Tectonic stress determination, Northen Piceance Creek Basin, Colorado, in Guidebook to energy resources of the Piceance basin, Colorado: Denver Rocky Mountain Association of Geologists, p. 193-198.

Zoback, M. D., Tsukahara, Hiroaki and Hickman, Steven, 1980 , Stress measurements at depth in the vicinity of the San Andreas Fault-Implications for the magnitude of shear stress at depth: Journal of Geophysical Research, v. 85 , no. B11, p. $6157-6173$.

Zoback, M. L., and Zoback, M. D., 1980, State of stress in the conterminous United States: Journal of Geophysical Research, v. 85, no. B11, p. $6113-6156$.

\section{SUBSIDENCE}

Bull, W. B., 1961, Causes and mechanics of near-surface subsidence in western Fresno County, California: U.S. Geological Survey Professional Paper 424-B, p. B187-B189.

Corliss, J. B., and Meade, R. H., 1964, Clay minerals from an area of land subsidence in the Houston-Galveston Bay Area, Texas, in Geological Survey Research, 1964: U.S. Geological Survey Professional Paper 501-C, p. C79-C81.

Meade, R. H., 1962, Relation of the pore volume of silty sediments to overburden load, particle size, and sorting, in Geological Survey Research, 1962: U.S. Geological Survey Professional Paper 450-E, p. E111-E114.

Poland, J. F., 1961, The coefficient of storage in a region of major subsidence caused by compaction of an aquifer system: U.S. Geological Survey Professional Paper 424-B, p. B52-B54.

1969, Status of present knowledge and needs for additional research on compaction of aquifer systems: Association Internationale d'Hydrologie Scientifique Actes du Colloque de Tokyo, Septembre Affaissement du sol, p. 11-21.

\section{TELEVISION}

Briggs, R. O., 1964, The downhole T.V. camera [abs.]: Society of Professional Well Log Analysts Annual Logging Symposium, 5th, Midland, Tex., 1964, Transactions, p. N1.

Lau, J. S. O., 1980, Borehole television survey: Canadian Institute of Mining and Metallurgy Canadian Rock Mechanics Symposium, 13th, Toronto, Ontario, 1980, Transactions, p. 204-210.

Mullins, J. E., 1966, Stereoscopic deep well photography in opaque fluids: Society of Professional Well Log Analysts Annual Logging Symposium, 7th, Tulsa, Okla., 1966, Transactions, p. N1-N9.

Storm, Erik, and others, 1979, Fisheye camera for surveying NTS boreholes, in Energy and technology review: Lawrence Livermore Laboratory, issued by the U.S. Department of Commerce, National Technical Information Service, Report UCRL-52000-79-10, p. 25-27.

\section{TEMPERATURE}

Adorni, N., and others, 1980, Construction of a probe for measuring temperature and pressure in deep wells: Geothermics, v. 9, no. 3-4, p. 251-259.

Albright, J. N., 1975, New and more accurate method for the direct measurements of earth temperature gradients in deep boreholes [abs.]: Los Alamos Scientific Laboratory, issued by the U.S. Department of Commerce, National Technical Information Service, Report CONF-750525-7, 1 p.

Anand, J., Somerton, W. H., and Gomaa, E., 1972, Prediction of thermal properties of formations from other known properties: Society of Petroleum Engineers of the American Institute of Mining, Metallurgical, and Petroleum Engineers Paper SPE 4171, 12 p.

Basham, R. B., and Macune, C. W., 1952, The Delta-log, a differential temperature surveying method: American Institute of Mining, Metallurgical, and Petroleum Engineers Transactions, v. 195, p. 123-128.

Beck, A. E., 1976, The use of thermal resistivity logs in stratigraphic correlation: Geophysics, v. 41, no. 21, p. 300-309.

Beck, A. E., Anglin, F. M., and Sass, J. H., 1971, Analysis of heat flow data-In situ thermal conductivity measurements: Canadian Journal of Earth Sciences, v. 8, no. 1, p. 2-19.

Beck, A. E., and Judge, A. S., 1969, Analysis of heat flow data-Detailed observations in a single borehole: Geophysical Journal of the Royal Astronomical Society, v. 18, no. 2, p. 145-158.

Bennett, Ken, 1965, Operating instructions-delta temperature tool: Fort Worth, Tex., Gearhart-Owen, Inc., 7 p.

Bird, J. E., and Frost, Noel, 1965, Formation productivity evaluation from temperature logs: Society of Professional Well Log Analysts Annual Logging Symposium, 6th, Dallas, Tex., 1965, Transactions, p. H1-H18.

Cocanower, R. D., Morris, B. P., and Dillingham, Mat, 1968, Computerized temperature decay an asset to temperature logging: Society of Petroleum Engineers of the American Institute of Mining, Metallurgical, and Petroleum Engineers Paper SPE 2255, 10 p.

Conaway, J. G., 1977, Deconvolution of temperature gradient logs: Geophysics, v. 42 , no. 4 , p. $823-837$. 
Conaway, J. G., and Beck, A. E., 1977, Fine-scale correlation between temperature gradient logs and lithology: Geophysics, v. 42, no. 7, p. 1401-1410.

Cooke, C. E., Jr., 1978, Radial differential temperature (RDT) logging-A new tool for detecting and treating flow behind casing: Society of Petroleum Engineers of the American Institute of Mining, Metallurgical, and Petroleum Engineers Paper SPE 7558, 8 p.

Cooke, C. E., Jr., and Meyer, A. J., 1979, Application of radial differential temperature (RDT) logging to detect and treat flow behind casing: Society of Professional Well Log Analysts Annual Logging Symposium, 20th, Tulsa, Okla., 1979, Transactions, p. UU1-UU7.

Costain, J. K., 1970, Probe response and continuous temperature measurements: Journal of Geophysical Research, v. 75 , no. 20 , p. $3969-3975$.

Curtis, M. R., and Witterholt, E. J., 1973, Use of the temperature $\log$ for determining flow rates in producing wells: Society of Petroleum Engineers of the American Institute of Mining, Metallurgical, and Petroleum Engineers Paper SPE 4637, 12 p.

Dowdle, W. L., and Cobb, W. M., 1974, Estimation of static formation temperature from well logs: Society of Petroleum Engineers of the American Institute of Mining, Metallurgical, and Petroleum Engineers Paper SPE 5036, 8 p.

Dziallas, J. W., and Hooper, L. J., 1968, Temperature distribution around a cylindrical probe in water: Water Power, v. 20 , no. 7 , p. 277-283.

Fertl, W. H., 1978, How subsurface temperature affects formation evaluation: Oil and Gas Journal, v. 76, no. 30, p. $54-62$.

Fertl, W. H., and Wichmann, P. A., 1977, How to determine static BHT from well log data: World Oil, v. 184 , no. 1 , p. 105-106.

Gearhart Owen International, Inc., 1971, An introduction to single element differential temperature logging: Fort Worth, Tex., 30 p.

Guyod, Hubert, 1946, Temperature well-logging, pt. 1-Heat conductions; pt. 2—Salt intrusions; pt. 3-Temperature distribution in the ground; pt. 4-Wells in thermal equilibrium; pt. 5 and $6-$ Wells not in thermal equilibrium, $\mathbf{A}$, rotary holes; pt. 7 -Conclusion: Oil Weekly, v. 123, no. 8 , p. $35-39$; no. 9 , p. $33-42$; no. 10 , p. $32-39$; no. 11 , p. $50-53$; v. 124 , no. 1 , p. $26-30$, $32-34$; no. 2 , p. $36-40$; no. 3, p. 38-40.

Hallock, William, 1897, Subterranean temperatures at Wheeling, W. Va. and Pittsburg, Pa.: Columbia University, School of Mines Quarterly, v. 18, p. 148-153.

Hoang, V. T., and Somerton, W. H., 1981, Effect of variable thermal conductivity of the formations on the fluid temperature distribution in the wellbore: Society of Professional Well Log Analysts Annual Logging Symposium, 22d, Mexico City, Mexico, 1981, Transactions, p. L1-L24.

Howell, E. P., Seth, M. S., and Perkins, T. K., 1972, Temperature calculations for wells which are completed through permafrost: Society of Petroleum Engineers of the American Institute of Mining, Metallurgical, and Petroleum Engineers Paper SPE 3969, $12 \mathrm{p}$.

Hutchins, J. S., and Kading, H. W., 1969, How to interpret temperature surveys-2: Oil and Gas Journal, v. 67, no. 34 , p. 96-103.
Johns, Earl, 1967, Tracing fluid movements with a new temperature technique: Society of Petroleum Engineers of the American Institute of Mining, Metallurgical, and Petroleum Engineers Paper SPE 1750, 8 p.

Johns, S. E., Jr., 1966, Tracing fluid movements with a new temperature technique: Fort Worth, Tex., GearhartOwen Industries, Inc., Bulletin no. EJ-416, 23 p.

Joslyn, C. D., and Chilton, L. F., 1970, Analysis of well problems through the use of differential temperature logs: American Petroleum Institute Spring Meeting of the Rocky Mountain District, Denver, Colo., 1970, Paper 87524-H, 13 p.

Kading, H. W., 1976, Horizontal-spinner, a new production logging technique: Log Analyst, v. 17. no. 5, p. 3-7.

Kading, H. W., and Hutchins, J. S., 1969, Temperature surveys - The art of interpretation: American Petroleum Institute Spring Meeting of the Southwestern District, Lubbock, Tex., 1969, Paper 906-14-N, 39 p.

Keller, H. H., Couch, E. J., and Baldwin, W. F., 1974, Quantitative interpretation of temperature logs: Society of Petroleum Engineers of the American Institute of Mining, Metallurgical, and Petroleum Engineers Paper SPE 5091, $8 \mathrm{p}$.

Kohout, F. A., 1967, Ground-water flow and the geothermal regime of the Floridian Plateau: Gulf Coast Association of Geological Societies Transactions, v. 17, p. 339-354.

Krige, L. J., 1939, Borehole temperatures in the Transvaal and Orange Free State: London, England, Proceedings of the Royal Society, Series A, v. 173, p. 450-474.

Morris, B. P., and Cocanower, R. D., 1968, Computers increase value of temperature logging: Petroleum Engineer International, v. 40, no. 13, p. 47-53.

Murphy, H. D., 1977, Fluid injection profiles-A modern analysis of wellbore temperature surveys: Society of Petroleum Engineers of the American Institute of Mining, Metallurgical, and Petroleum Engineers Paper SPE 6783, 8 p.

Nowak, R. J., 1953, The estimation of water injection profiles from temperature surveys: American Institute of Mining, Metallurgical, and Petroleum Engineers Transactions, v. 198, p. 203-212.

Parker, J. D., 1971, Basics of thermal conductivity, specific heat: Oil, Gas and Petrochemistry Equipment, v. 17, no. 11, p. 4-5.

Peacock, D. R., 1965, Temperature logging: Society of Professional Well Log Analysts Annual Logging Symposium, 6th, Dallas, Tex., 1965, Transactions, p. F1-F18.

Pennebaker, E. S., Jr., and Woody, R. T., 1977, The temperature-sound $\log$ and borehole channel scans for problem wells: Society of Petroleum Engineers of the American Institute of Mining, Metallurgical, and Petroleum Engineers Paper SPE 6782, 12 p.

Sammel, E. A., 1968, Convective flow and its effect on temperature logging in small-diameter wells: Geophysics, v. 33, no. 6, p. 1004-1012.

Schneider, Robert, 1962, An application of thermometry to the study of ground water: U.S. Geological Survey WaterSupply Paper 1544-B, p. B1-B16.

1972, Distortion of the geothermal field in aquifers by pumping, in Geological Survey Research 1972: U.S. Geological Survey Professional Paper 800-C, p. C267C270. 
Simmons, Gene, 1966, Temperature logging and heat flow: Society of Professional Well Log Analysts Annual Logging Symposium, 7th, Tulsa, Okla., 1966, Transactions, p. I1I9.

Smith, R. C., and Steffensen, R. J., 1970, Computer study of factors affecting temperature profiles in water injection wells: Journal of Petroleum Technology, v. 22, no. 11, p. 1447-1458.

1973, Improved interpretation guidelines for temperature profiles in water injection wells: Society of Petroleum Engineers of the American Institute of Mining, Metallurgical, and Petroleum Engineers Paper SPE 4649, 12 p.

1975 , Interpretation of temperature profiles in water-injection wells: Journal of Petroleum Technology, v. 27, no. 6, p. 777-784.

Sorey, M. L., 1971, Measurement of vertical groundwater velocity from temperature profiles in wells: Water Resources Research, v. 7, no. 4, p. 963-970.

Steffensen, R. J., and Smith, R. C., 1973, The importance of Joule-Thomson heating (or cooling) in temperature log interpretation: Society of Petroleum Engineers of the American Institute of Mining, Metallurgical, and Petroleum Engineers Paper SPE 4636, 14 p.

Stevens, H. H., Jr., Ficke, J. F., and Smoot, G. F., 1975, Water temperature-Influential factors, field measurement and data presentation: U.S. Geological Survey Techniques of Water Resources Investigations, Book 1, Chapter D1, $65 \mathrm{p}$.

Tait, D. B., 1972, Geohydrology of the Piceance Creek basin, Colorado: Society of Petroleum Engineers of the American Institute of Mining, Metallurgical, and Petroleum Engineers Paper SPE 4046, 7 p.

Van Orstrand, C. E., 1951, Apparatus for the measurements of temperatures in deep wells, and temperature determinations in some deep wells in Pennsylvania and West Virginia, in Reger, D. B., and Teets, D. D., Jr., eds., West Virginia Geological Survey County Reports of Barbour and Upshur Counties and western portion of Randolph County: West Virginia Geological Survey, p. 61, 62, 86.

Winslow, J. D., 1962, Effect of stream infiltration on groundwater temperatures near Schenectady, New York, in Geological Survey Research 1962: U.S. Geological Survey Professional Paper 450-C, p. C125-C128.

Witterholt, E. J., and Tixier, M. P., 1972, Temperature logging in injection wells: Society of Petroleum Engineers of the American Institute of Mining, Metallurgical, and Petroleum Engineers Paper SPE 4022, 12 p.

\section{TRACERS}

Alekseev, F. A., and Srebrodolsky, D. M., 1967, Radioactive tracers in geophysics, in Radioisotopes in industry and geophysics-a symposium, Prague, 1966, Proceedings: Vienna, Austria, International Atomic Energy Agency, p. 133-149.

Arnold, D. M., and Paap, H. J., 1979, Quantitative monitoring of water flow behind and in wellbore casing: Journal of Petroleum Technology, v. 31, no. 1, p. 121-130.

Baetsle, L. H. and Souffriau, J., 1967, Fundamentals of the dispersion of radionuclides in sandy aquifers, in Isotopes in hydrology - a symposium, Vienna, 1966, Proceedings: Vienna, Austria, International Atomic Energy Agency, p. $617-627$.
Churchill, T. R., 1967, Production of short-lived radioisotope tracers with an $\mathrm{Sb}:$ Be source, in Radioisotopes in industry and geophysics - a symposium, Prague, 1966, Proceedings: Vienna, Austria, International Atomic Energy Agency, p. 271-288.

Clayton, C. G., 1964, The use of a pump to reduce mixing length in the dilution method of flow measurement: Wantage, Berkshire, England, Atomic Energy Research Establishment, Report AERE-R 4623, 9 p.

1967, Measurement of flow of liquids and gases using radioactive isotopes: Isotopes and Radiation Technology, v. 4, no. 2, p. 93-108.

Clayton, C. G., Ball, A. M., and Spackman, R., 1968, Dispersion and mixing during turbulent flow of water in a circular pipe: Wantage, Berkshire, England Atomic Energy Research Establishment, Report AERE-R 5569, 13 p.

Clayton, C. G., Spackman, R., and Ball, A. M., 1967, The accuracy and precision of liquid flow measurement by radioactive isotopes, in Radioisotope tracers in industry and geophysics—a symposium, Prague, 1966, Proceedings: Vienna, Austria, International Atomic Energy Agency, p. 563-589.

Cooley, B. B., 1971, Nitrate in drilling fluid as a tracer ion: Society of Professional Well Log Analysts Annual Logging Symposium, 12th, Dallas, Tex., 1971, Transactions, p. D1D7.

Drost, Walter, 1970, Groundwater measurements at the site of the Sylvenstein Dam in the Bavarian Alps, in Isotopes in Hydrology-a symposium, Vienna, 1970, Proceedings: Vienna, Austria, International Atomic Energy Agency, p. 421-437.

Drost, Walter, and others, 1968, The borehole dilution method of measuring groundwater filtration. velocity: Munich 2, Germany, Institut fur Radiohydrometric der Gesellschaft fur Strahlenforschung M.B.H., Report GSF-Bericht R 16, $45 \mathrm{p}$.

Edwards, J. M., and Holter, E. L., 1954, How to use radioactive isotopes for water-input profiles in water-flood operations: Oil and Gas Journal, v. 54, no. 30, p. 69-70.

1962, Applications of a subsurface solid-state isotope injector to nuclear-tracer survey methods: Journal of Petroleum Technology, v. 14, no. 2, p. 121-124.

Ford, W. O., Jr., 1962, How new injectivity profiling method works: World Oil, v. 155, no. 2, p. 43-47.

Gaspar, Emlian, and Oncescu, Mircea, 1964, The sensitivity and the precision of radiometric methods for the determination of the flow rate of ground waters: Hidrotehnica, v. 9, no. 11, p. 585-590, and Glen Ridge, N.J., Associated Technical Services, Inc., $10 \mathrm{p}$.

Haaser, F. G., and others, 1978, Use of neutron activatable tracers for simulating water and chemical flow through porous media: Pennsylvania State University, Institute of Research on Land and Water Resources, $306 \mathrm{p}$.

Halevy, E., and Nir, A., 1962, The determination of aquifer parameters with the aid of radioactive tracers: Journal of Geophysical Research, v. 67, no. 6, p. 2403-2409.

Jenkins, R. E., and Koepf, E. H., 1963, New tools and methods improve fluid tracing: Oil and Gas Journal, v. 61, no. 13 , p. 102-104. 
Johnson, Wallace, and Morris, B. P., 1964, Review of tracer surveys: American Petroleum Institute, Spring Meeting of the Southwestern District, Midland, Tex., 1964, Paper 906-9-E, 25 p.

Kaveler, H. H., and Hunter Z. Z., 1952, Observations from profile logs of water injections wells: American Institute of Mining, Metallurgical, and Petroleum Engineers, Transactions, v. 195, p. 129-134.

Kelldorf, W. F. N., 1969, Radioactive tracer surveying-A comprehensive report: Society of Petroleum Engineers of the American Institute of Mining, Metallurgical, and $\mathrm{Pe}$ troleum Engineers Paper SPE 2413, 9 p.

Keys, W. S., 1967, The application of radiation logs to groundwater hydrology, in Isotopes in Hydrology-a symposium, Vienna, 1966, Proceedings: Vienna, Austria, International Atomic Energy Agency, p. 477-488.

Klett, R. D., Tyner, C. E., and Hertel, E. S., Jr., 1981, Geologic flow characterization using tracer techniques: Sandia National Laboratories, issued by the U.S. Department of Commerce, National Technical Information Service, Report SAND80-0454, $84 \mathrm{p}$.

Lafferty, R. H., Jr., 1971, Flow measurements with radioisotopes, in Isotope technology development, section II: Isotopes and Radiation Technology, v. 8 , no. 3, p. 287309.

Lewis, D. C., Kriz, G. J., and Burgy, R. H., 1966, Tracer dilution sampling technique to determine hydraulic conductivity of fractured rock: Water Resources Research, v. 2 , no. 3, p. 533-542.

Lichtenberger, G. J., 1981, A primer on radioactive tracer injection profiling: Annual Southwestern Petroleum Short Course, 28th, Lubbock, Tex., 1981, Proceedings, p. 251265.

Mairhofer, J., 1967, Groundwater flow and direction measurement by means of radioisotopes in a single well, in Stout, G. E., ed., Isotope techniques in the hydrologic cycle: Geophysical Monographs of the American Geophysical Union, Series no. 11, p. 119-129.

Marine, I. W., 1965, Correlation and water-transmitting properties of fractures: Society of Petroleum Engineers of the American Institute of Mining, Metallurgical, and Petroleum Engineers Paper SPE 1280, 6 p.

1979, Determination of the location and connectivity of fractures in metamorphic rock with in-hole tracers: U.S. Department of Commerce, National Technical Information Service, Report CONF-790320-2, P. 1-15.

Mercado, A., and Halevy, E., 1966, Determining the average porosity and permeability of a stratified aquifer with the aid of radioactive tracers: Water Resources Research, v. 2, no. 3, p. 525-531.

Millar, R. H. G., and Buckles, R. S., 1974, Tritiated water as a drilling mud tracer in Beaufort exploration wells: Petroleum Society of Canadian Institute of Mining and Metallurgy Annual Meeting, 25th, Calgary, 1974, Paper 374030, 5 p.

Morris, D. A., 1967, Use of chemical and radioactive tracers at the National Reactor Testing Station, Idaho, in Stout, G. E., ed., Isotope techniques in the hydrological cycle: Geophysical Monographs of the American Geophysical Union, no. 11, p. 130-142.
Mott, W. E., and Dempsey, J. C., 1967, Review of radiotracer applications in geophysics in the United States of America, in Radioisotopes tracers in industry and geophysics - a symposium, Prague, 1967, Proceedings: Vienna, Austria, International Atomic Energy Agency, p. 111-131.

Payne, B. R., and others, 1964, The role of radioisotope techniques in hydrology: Vienna, Austria, International Atomic Energy Agency Symposium, 1964, Proceedings, p. 226-238.

Peterson, J. E., 1972, Use of the interface survey in irregular boreholes: Society of Petroleum Engineers of the American Institute of Mining, Metallurgical, and Petroleum Engineers Paper SPE 4021, 8 p.

Richardson, J. E., 1977, Monitoring flood profiles with induction logs: Society of Petroleum Engineers of the American Institute of Mining, Metallurgical, and Petroleum Engineers Paper SPE 6785, $7 \mathrm{p}$.

Roesner, R. E., and others, 1982, Visual flow loop investigation of nuclear flolog performance in non-Newtonian fluids: Society of Professional Well Log Analysts Annual Logging Symposium, 23d, Corpus Christi, Tex., 1982, Transactions, p. JJ1-JJ18.

Scott, H. D., Paap, H. J., and Arnold, D. M., 1980, Logging method for determining horizontal velocity of water in oilfield formations: Journal of Petroleum Technology, v. 32, no. 4 , p. $675-684$.

Tittle, C. W., 1966, Applications of radioisotope instruments in geophysics, in Radioisotope instruments in industry and geophysics-a symposium, Prague, 1966, Proceedings: Vienna, Austria, International Atomic Energy Agency, p. 3-13.

Vetter, O. J., and Zinnow, K. P., 1981, Evaluation of well-towell tracers for geothermal reservoirs, pt. 1-Literature survey, pt. 2-Laboratory work: Lawrence Berkeley Laboratory, issued by the U.S. Department of Commerce, National Technical Information Service, Report LBL$11500,68 \mathrm{p}$.

Webster, D. S., Proctor, J. F., and Marine, I. W., 1970, Twowell tracer test in fractured crystalline rock: U.S. Geological Survey Water-Supply Paper 1544-I, p. I1-I22.

Wiebenga, W. A., and others, 1967, Radioisotopes as groundwater tracers: Journal of Geophysical Research, v. 72, no. 16 , p. $4081-4091$.

\section{WASTE DISPOSAL, CENERAL}

Advisory Committee on Underground injection of wastewaters, 1973, Underground injection of wastewaters in Ohio Valley region: Cincinnati, Ohio, Ohio River Valley Water Sanitation Commission, 63 p.

Black, Crow, and Eidsness, Inc., 1970, Drilling and testing of deep disposal well for Peninsula Utilities Corporation, Coral Gables, Florida: Gainesville, Fla., Engineering Report Project no. 498-70-53, 9 p.

1972, Modification to deep-well disposal system-Effect on monitoring wells and future monitoring wells and future monitoring requirements for Sugar Cane Growers Cooperative of Florida, Belle Glade, Palm Beach County, Florida: Gainesville, Fla., Engineering Report Project no. 386-71-01, 29 p. 
1972, The drilling and testing of the second deep injection well for General Waterworks Corporation at Kendale Lakes Wastewater Treatment Plant, Dade County, Florida: Gainesville, Fla., Engineering Report Project no. 498-71-01 (4), 10 p.

Kaufman, M. I., 1973, Subsurface wastewater injection, Florida: Journal of the Irrigation and Drainage Division, American Society of Civil Engineers, v. 99, no. IR1, March, p. 53-70.

Keys, W. S., and Brown, R. F., 1973, The role of borehole geophysics in underground waste storage and artificial recharge: Symposium on Underground Waste Management and Artificial Recharge, 2d, New Orleans, La., p. 147191.

Warner, D. L., 1975, Monitoring disposal-well systems: Environmental Protection Agency, issued by the U.S. Department of Commerce, National Technical Information Service, Report EPA-680/4-75-008, 99 p.

Warner, D. L., and Lehr, J. H., 1977, An introduction to the technology of subsurface wastewater injection: Environmental Protection Agency, issued by the U.S. Department of Commerce, National Technical Information Service, Report EPA-600/2-77-240, 345 p.

\section{WASTE DISPOSAL, RADIOACTIVE}

Barraclough, J. T., Robertson, J. B., and Janzer, V. J., 1976, Hydrology of the solid waste burial ground as related to the potential migration of radionuclides, Idaho National Engineering Laboratory: U.S. Department of Commerce, National Technical Information Service, Report IDO22056, $183 \mathrm{p}$.

Brown, R. E., and Raymond, J. R., 1961, The measurement of Hanford's geohydrologic features affecting waste disposal: Richland, Wash., General Electric Company, Hanford Laboratories Report HW-SA-2260, 21 p.

Burgus, W. H., and Maestas, S. E., 1976, The 1975 RWMC core drilling program, a further investigation of subsurface radioactivity at the Radioactive Waste Management Complex, Idaho National Engineering Laboratory: U.S. Department of Commerce, National Technical Information Service, Report IDO-10065, 36 p.

Davison, C. C., Keys, W. S., and Paillet, F. L., 1982, Use of borehole-geophysical logs and hydrologic tests to characterize crystalline rock for nuclear-waste storage, Whiteshell Nuclear Research Establishment, Manitoba, and Chalk River Nuclear Laboratory, Ontario, Canada: U.S. Department of Energy, issued by the U.S. Department of Commerce, National Technical Information Service, Report ONWI-418, 103 p.

de Laguna, Wallace, 1970, Radioactive waste disposal by hydraulic fracturing: Nuclear Safety, v. 11, no. 5, p. 391-400.

Eggers, D. E., 1976, The application of borehole geophysics to the selection and monitoring of nuclear waste disposal sites: U.S. Symposium on Rock Mechanics, 17th, Snowbird, Utah, 1976, Proceedings, p. 4BC-0-4B3-7.

Grisak, G. E., and Jackson, R. E., 1978, An appraisal of hydrogeological processes involved in shallow subsurface radioactive waste management in Canadian terrain: Ottawa, Canada, Inland Waters Directorate, Water Resources Branch Scientific Series no. 84, 194 p.
Horan, J. R., Wehman, George, and Schmalz, B. L., 1962, Experience in site selection at the National Reactor Testing Station, USA: U.S. Atomic Energy Commission, issued by the U.S. Department of Commerce, National Technical Information Service, Report IDO-12012, 36 p.

Jones, P. H., 1961, Geophysical research at the National Reactor Testing Station, Idaho: U.S. Atomic Energy Commission, Conference on Ground Disposal of Radioactive Wastes, 2d, Chalk River, Ontario, Canada, 14 p.

Jones, P. H., and Schmalz, B. L., 1962, Distribution of radionuclides in groundwater at the National Reactor Testing Station with particular reference to tritium: American Geophysical Union Annual Meeting, 43d, Washington, D.C., p. 1-24.

Keys, W. S., and Brown, R. F., 1973, Role of borehole geophysics in undergound waste storage and artificial recharge, in Braunstein, Jules, ed., Underground waste management and artificial recharge: Symposium on Underground Waste Management and Artificial Recharge, 2d, New Orleans, La., 1973, Proceedings, p. 147-191.

Keys, W. S., Eggers, D. E., and Taylor, T. A., 1979, Borehole geophysics as applied to the management of radioactive waste-Site selection and monitoring, in Carter, M. W., Moghissi, A. A., and Kahn, Bernd, eds., Management of low-level radioactive waste: New York, Pergamon Press, v. 2, p. 955-982.

Morris, D. A., and others, 1964, Hydrology of subsurface waste disposal, National Reactor Testing Station, IdahoAnnual progress report: U.S. Atomic Energy Commission, issued by the U.S. Department of Commerce, National Technical Information Service, Report IDO-22047-USGS, $147 \mathrm{p}$.

Nace, R. L., and others, 1975, Generalized geologic framework of the National Reactor Testing Station, Idaho: U.S. Geological Survey Professional Paper 725-B, p. B1-B49.

Nelson, P. H., Magnusson, K. A., and Rachiele, R., 1982, Application of borehole geophysics at an experimental waste disposal site: Geophysical Prospecting, v. 30, no. 6, p. 910 934.

Olmsted, F. H., 1962, Chemical and physical character of ground water in the National Reactor Testing Station, Idaho: U.S. Atomic Energy Commission, issued by the U.S. Department of Commerce, National Technical Information Service, Report IDO-22043-USGS, 81 p.

Papadopulos, S. S., and Winograd, I. J., 1974, Storage of lowlevel radioactive wastes in the ground-Hydrogeologic and hydrochemical factors: U.S. Environmental Protection Agency, issued by the U.S. Department of Commerce, National Technical Information Service, Report EPA-520/ 3-74-009, 49 p.

Pickett, G. R., 1968, Properties of the Rocky Mountain Arsenal disposal reservoir and their relation to Derby earthquakes, in Geophysical and geological studies of the relationships between the Denver earthquake and the Rocky Mountain Arsenal well, pt A: Quarterly of the Colorado School of Mines, v. 63, no. 1, p. 73-100.

Schmalz, B. L., and Keys, W. S., 1962, Retention and migration of radioactive isotopes in the lithosphere at the $\mathrm{Na}$ tional Reactor Testing Station, Idaho: U.S. Atomic Energy Commission, issued by the U.S. Department of Commerce, National Technical Information Service, Report IDO-12026, 26 p. 
Sun, R. J., and Mongan, C. E., 1974, Hydraulic fracturing in shale at West Valley, New York-A study of bedding plane fractures induced in shale for waste disposal: U.S. Geological Survey Open-File Report 74-365, 152 p.

U.S. Geological Survey, 1962, Hydrology of waste disposal, National Reactor Testing Station, Idaho-Annual progress report: U.S. Department of Commerce, National Technical Information Service, Report ID0-22044-USGS, $99 \mathrm{p}$.

Winograd, I. J., 1974, Radioactive waste storage in the arid zone: American Geophysical Union Transactions, v. 55, no. 10 , p. 884-894.

1981, Radioactive waste disposal in thick unsaturated zones: Science, v. 212, no. 4502, p. 1457-1464.

Wolff, R. G., and others, 1975, Stress determination by hydraulic fracturing in subsurface water injection: Journal of the American Water Works Association, v. 67, no. 9, p. 519-524.

\section{WATER SATURATION}

Barlai, Zoltan, 1970, Well logging parameters of hydrocarbonbearing sandstones composed of sand, silt, and shaleEvaluation of water saturation, porosity and grain-size distribution: Log Analyst, v. 11, no. 2, p. 3-22.

Fertl, W. H., and Hammack, G. W., 1971, A comparative look at water saturation computations in shaly pay sands: Society of Professional Well Log Analysts Annual Logging Symposium, 12th, Dallas., Tex., 1971, Transactions, p. R1-R18.
Khelil, Chakib, 1971, Analysis of errors in logging parameters and their effects on calculating water saturation: Society of Professional Well Log Analysts Annual Logging Symposium, 12th, Dallas, Tex., 1971, Transáctions, p. A1A17.

Krygowski, Daniel, 1977, The use of well logs to predict water saturation and recoverable hydrocarbon volumes in shaly sand reservoirs [Colorado School of Mines, Ph. D. dissertation]: University Microfilms, International, Publication no. 79-12218, 159 p.

Pickett, G. R., 1973, Pattern recognition as a means of formation evaluation: Log Analyst, v. 14, no. 4, p. 3-11.

Poupon, Andre, and Leveaux, J., 1971, Evaluation of water saturation in shaly formations [abs.]: Society of Professional Well Log Analysts Annual Logging Symposium, 12th, Dallas, Tex., 1971, Transactions, p. 01-02.

Westbrook, L. P., 1971, Average water saturation from capillary pressure data: Society of Professional Well Log Analysts Annual Logging Symposium, 12th, Dallas, Tex., 1971, Transactions, p. F1-F12.

\section{REFERENCES CITED}

U.S. Department of Commerce, 1981, National Resources and Earth Sciences: U.S. Department of Commerce, National Technical Information Service, General Catalog no. 7a, 32 p.

University of Tulsa, 1983, Petroleum Abstracts Price List: Tulsa, Okla., Division of Information Services, $10 \mathrm{p}$. 



\section{AUTHOR INDEX}

Page

Aamodt, R. L. ........... 21, 27

Abdassah, D. ............. 27

Abeele, w. V. . . . . . . . . . . 34

Abou-Sayed, A. S. .......... 2

Acevedo, L. . . . . . . . . . 20

Adams, J. A. S. . . . . . . . . . 24

Adams, W. M. . . . . . . . . . . 11, 46

Adorni, N. . . . . . . . . . . . . 27, 48 Advisory Committee on Underground Injection of

Waste Water ............. 51

Aguilera, R. ........... 7, 20

Ahmed, A. E. ............. 12

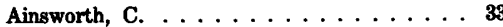

Albright, J. C. . . . . . . . . . . 16

Albright, J. N. . . . . . . . . 2, 48

Alekseev, F. A. . . . . . . . . . 50

Alger, R. P. . . . . . . . 4, 7, 10, 11, 13,

$19,22,24,34,44,46$

Algermissen, S. T. . . . . . . 7, 39

Allen, J. W. . . . . . . . . . . . . 33

Allen, L. S. . . . . . . . . . . 34, 42

Alparone, N. . . . . . . . . . . . 22

Al-Saif, A. S. . . . . . . . . . 43

Althaus, v. . . . . . . . . . 13

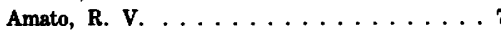

American Petroleum Institute ........ 12

Anand, J. .................. 48

Anderson, A. L. . . . . . . . . . . . 4

Anderson, J. V. ............ 31

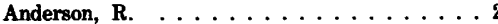

Anderson, R. A. . . . . . . . 2,

Anderson, R. N. ...........

Anderson, T. $0 . \ldots \ldots \ldots \ldots$

Anderson, w. B. .......... 7, 13

Anderson, W. L. . . . . . . . . .

Andrassy, L. . . . . . . . . . . . 22

Anglin, F. M. ............4 48

Ansell, K. H. . . . . . . . . . . 34

Antkiw, S. . . . . . . . . . . 36, 43

Anton, H. .............. 41

Apparao, A. . . . . . . . . . 46

Archuleta, J. R. . . . . . . . . . . . 27

Arditty, P. C. ............. 2

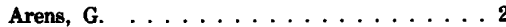

Aripzhanov,A. A. .......... 10

Arkadyev, E. A. . . . . . . . . 32

Arkfeld, T. E. . . . . . . . . . . .

Arney, B. . . . . . . . . . 28

Arnold, D. M. . . . . . . . . 34, 50, 51

Arnold, J. S. . . . . . . . . . 18

Arnold, R. . . . . . . . . . . . . . 39

Arnoult, E. B., Jr. . . . . . . . . 17

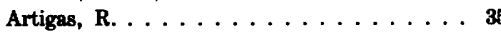

Artus, D. S. . . . . . . . . . 12, 29

Atal, B. S. . . . . . . . . . . 22

Atkinson, A. ............ 32, 38

Attali, G. . . . . . . . . . . . . 18

Atwood, J. W. . . . . . . . . . 13, 27

Aufricht, W. R. . ........... 16

Avadisian, A. ............ 22

Ayed, M. A. . . . . . . . . . . .477
Page

B

Babcock, E. A. ............20

Bacon, L. O. . . . . . . . . . . 3

Baetsle, L. H. . . . . . . . . . . . . 50

Bains, A. J. . . . . . . . . . . . . . . 14

Baker, L. E. . . . . . . . . . . . . 27

Baker, L. J. . . . . . . . . . . . .

Baker, P. E. . . . . . . . . . . . . . . 22, 37

Baksi, S. S.

Baldwin, J. L. . . . . . . . . . 26

Baldwin, W. F. . . . . . . . 22, 49

Ball, A. M. . . . . . . . . . . 50

Ball, L. w. ............. 27

Baltosser, R. W. . . . . . . . . 3, 7, 12

Bamber, C. L. . . . . . . . . . . 40

Barnanov, V. I. . . . . . . . . . . 24

Bardsley, S. R. . . . . . . . . 7, 39

Barksdale, w. L. . . . . . . . . . 39

Barlai, Z. . . . . . . . 7, 40, 41, 46, 58

Barnett, M. E. . . . . . . . . . .

Barraclough, J. T. . . . . . . . . . 29, 52

Barry, A. . . . . . . . . . . . 29

Barsukov, 0. A. . . . . . . . . 7, 11

Barth, J. J. . . . . . . . . . . 3

Barton, W. F. . . . . . . . . .

Bashan, R. B. . . . . . . . . . . 48

Basin, Y. N. . . . . . . . . . 35

Bassiouni, Z. . . . . . . . . . . 4

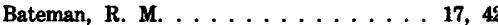

Bates, A. . . . . . . . . . . . 19

Bays, C. A. . . . . . . . . . 29

Bearden, W. G. . . . . . . . . . 32

Bebout, J. W. . . . . . . . . . . . 7

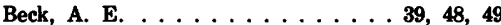

Beck, J. A. . . . . . . . . . . 12

Beckmann, H. . . ......... 4

Bedwell, J. L. . . . . . . . . . . . 32

Belcher, D. J. . . . . . . . . . . 34

Belen'kii, Ya. E. . . . . . . . . . 44

Bennett, G. D. . . . . . . . . . . 19

Bennett, K. . . . . . . . . . 48

Berezkin, V. M. . . . . . . . . . . 2

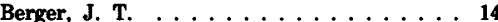

Berkoff, E. W. . . . . . . . . . 12

Berry, J. E. . . . . . . . . . . 2

Best, D. L. . . . . . . . . . 17, 39

Beyer, R. F. . . . . . . . . . 44

Bhatnagar, A. S. ........ 22

Bicker, A. R., Jr. . . . . . . . . . .

Bickham, R. E. . . . . . . . . . 28

Biggar, J. w. . . . . . . . . . 23

Biggs, W. P.

Bilhartz, H L Jr.

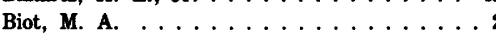

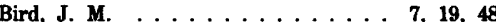

Birdwell Division ........... 32

Bishop, B. $0 . \ldots \ldots \ldots \ldots \ldots$

Bishop, J. M. . . . . . . . . . 22

Bishop, W. D. . . . . . . . . . . . 37

Bixley, P. F. . . . . . . . 19, 29

Black, Crow, and Eidsness, Inc. . . . 51, 52

Blakeman, E. R. ..........42,44

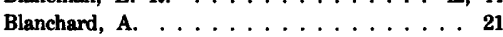

Page

Blankennagel, R. K. . . . . . . 7, 29 Blanks, G. L. . . . . . . . . . . 19, 30

Blakely, R. F. . . . . . . . . 15

Blizard, R. B. . . . . . . . . . . 3

Boatman, W. A., Jr. . . . . . . . 42

Bodare, A. ............. 6

Bodmer, R. .............. 31

Boganik, v. N. . . . . . . . . . 31

Bogoslovsky, V. A. . . . . . . . . 47

Bollman, D. . . . . . . . . . 16

Bond, L. 0. $\ldots \ldots \ldots \ldots \ldots$

Bonnet, J. L. . . . . . . . . . . 40

Boss, F. E. ............... . . 2

Bosworth, A. F. . . . . . . . . . 7

Boulogne, A. R. . . . . . . . . 34, 38

Bowden, J. C. . . . . . . . . . . . . 17

Bower, F. M. . . . . . . . . . 19

Bowers, B. . . . . . . . . . . . . . 44

Bowman, w. w. .......... 24

Boyeldieu, C. ........... 23

Boynton, G. R. . . . . . . . . . . . 24

Bradley, J. S. . . . . . . . . . . 44

Bradley, w. A. . . . . . . . . . . 23

Branisa, F. . . . . . . . . . . 13

Brannon, H. R., Jr. . . . . . . . . 24

Bredehoeft, J. D. . . . . . . . . . . 40

Brietenbach, E. A. . . . . . . . 7, 13

Bricaud, J. M. . . . . . . . . . . 18

Briggs, R. 0. . . . . . . . . . 48

Bristow, Q. . . . . . . . 21, 24, 25

Britt, E. L. . . . . . . . . . . 19

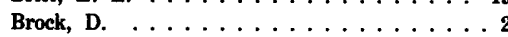

Broding, R. A. ............

Brodzinski, R. L. . . . . . . . 24, 26

Brotzen, 0. ............

Brown, A. A. . . . . . . . . 41

Brown, A. E. ............. 19

Brown, D. L. . . . . . . . . 7, 4

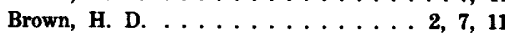

Brown, J. . . ........... 39

Brown, J. A. ............ 39

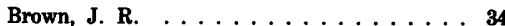

Brown, J. S. . . . . . . . . . . 7

Brown, K. W. ................ 19

Brown, M. P. . . . . . . . . 17

Brown, R. E. $\ldots \ldots \ldots \ldots \ldots \ldots \ldots \ldots \ldots$

Brown, R. F. ........ 6, 7, 52

Brown, R. S. ............ 39

Brown, S. L. ............ 42

Brown and Root, Ine. ......... 32

Browne, E. J. P. . . . . . . . 17

Brownell, L. E. . . . . . . . . . 39

Buckles, R. S. . . . . . . . . . 51

Buckner, G. 0. . . . . . . . . 14, 34

Buford, T. B. . . . . . . . . 45

Bull, w. B. . . . . . . . . . . 48

Bullard, H. M. . . . . . . . . . 19

Bunker, C. M. . . . . . . . . . 21, 23, 24

Burdin, Yu. B. . . . . . . . . . 24

Burgus, w. H. $\ldots \ldots \ldots \ldots \ldots \ldots$

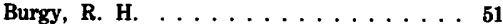

Burke, J. A. . . . . . . . . . 2, 17, 41

Burns, W. A., Jr. . . . . . . . . 40

Burova, E. G. . . . . . . . . . 41 
Bush, C. A. ........... 24 Bush, D. C. .............. 22

Byerley, K. A.

Cable, H. W.

Cahill, J.

Caldwell, J.

Caldwell, J. W.

Caldwell, R. L.

Calissendorff,

Calvert, T. J.

Camargo, 0.

Cameron, J. F

Campbell, A. B.

Campbell, A. T.

Campbell, G. S.

Campbell, J. L.

Campbell, J. M.

Campbell, R. .

Campbell, R. L., Jr.

Campbell, R. M.

Candra, D.

Carlson, R. C.

Carlton, A. W.

Carmichael, C. M.

Carothers, J. E.

Carroll, R. D.

Carter, L. G.

Carter, V. B.

(

Castagna, J. P. . . . . . . . . 2, 6

Cazal, A. . . . . . . . . . 45

Chancellor, R. E. . . . . . . . . . 39

Chaney, P. E. . . . . . . . . . . .

Chang, H-T. . . . . . . . . .

Chapman, H. T. ............ 19

Charlson, G. S. ............ 43

Chen, B. ................. 29

Chen, s. T. $\ldots \ldots \ldots \ldots \ldots \ldots$

Cheng, C. H. .......... 2,5,6

Chessmore, R. B. . . . . . . . . . 33

Chiarelli, A. . . . . . . . . . . 27

Chicko, R. S. . . . . . . . . 15

Chilingar, G. V. . . . . . . . . . 40

Chilton, L. F. . . . . . . . . . 49

Chombart, L. G.

Choquette, P. W.

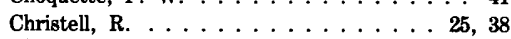

Christensen, D. M. ...........

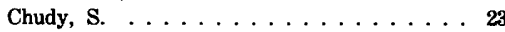

Churchill, T. R. ........... 50

Churinova, I. M. . . . . . . . . 15

Clayton, C. G. . . . . . . . 8, 33, 36, 50

Clements, J. R. . . . . . . . . . . 8

Close, D. A. . . . . . . . . . 25

Clothier, A. T.

Coalson, E. B

Coates, G. R.

Cobb, W. M

Cocanower, R. D. . . . . . . . . 32, 48, 49

Cochran, L. E. . . . . . . . . . 27

Cochrane, J. E. . . . . . . . . . . 12

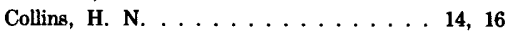

Comb, J.

Commission on Standardization of Laboratory

and Field Tests

Conaway, J. G.

Connell, J. G.

Conner, D. C.

Connolly, E, T.

Cook, C. F.

Cook, J. C.
Cooke, C. E., Jr. . . . . . . . . . . . 49

Cooley, B. B. . . . . . . . . . 42, 50

Coolidge, J. E. . . . . . . . . . . . 8

Core Laboratories, Inc. . . . . . . . . . 2

Corey, J. C. . . . . . . . . 16, 23, 34

Corliss, J. B. . . . . . . . . . . 48

Costain, J. K. . . . . . . . . . . 49

Cotecchia, V. .............. 34

Cotterell, C. H. . . . . . . . . . 2

Couch, E. J. . . . . . . . . . . . 49 49

Courtois, G. . . . . . . . . . 23

Couturie, S. H. $\ldots \ldots \ldots \ldots \ldots$

Cox, J. W. . . . . . . . . . . . . 18

Cox, P. T. . . . . . . . . . 17

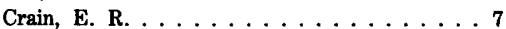

Cram, M. E. . . . . . . . . . . 12

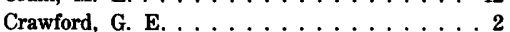

Crawford, T. R. . . . . . . . . . 39

Crew, M. E. . . . . . . . . . . . . 12

Croft, M. G. . . . . . . . . . . . 40,44

Crosby, J. W., III $\ldots \ldots \ldots \ldots \ldots$. . $\ldots \ldots, 31$

Culver, R. B. . . . . . . . . . . 37

Cunningham, J. D. $\ldots \ldots \ldots \ldots \ldots$

Cunningham, M. J. . . . . . . . 7

Cunningham, W. A. ......... 47

Currie, R. L. . . . . . . . . . . . . . . . . . 34

Curtis, M. R. . . . . . . . . . 49

Cuthbert, J. F. . . . . . . . . . . 12

Cuykendall, T. R. . . . . . . . . 34

Czubek, J. A. . . . . . . . 8, 16, 21, 23,

33, 37

\section{D}

Dahl, J. B. . . . . . . . . . . . . 21

Dailey, P. . . . . . . . . . . . 18

Dakhnov, v. N. . . . . . . . . . 8, 31

Daniel, G. . . . . . . . . . . . . . . . . . . . 30

Daniell, G. J. . . . . . . . . . . . 33

Daniels, J. J. . . . . . . . . 8, 13, 14, 31,

Darnley, A. G. . . . . . . . . . . 25

Davidson, J. M. . . . . . . . . . . . . . . 23, 37

Davis, C. E. . . . . . . . . . . . 31

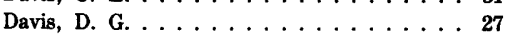

Davis, J. C. ............. 11

Davis, R. R. . . . . . . . . . . . 34

Davis, R. W. . . . . . . . . . . 29

Davison, C. C. . . . . . . . . . 52

Dawson-Grove, G. E. . . . . . . . . . 12

Day, E. A. . . . . . . . . . . 28

Deadrick, F. J. . . . . . . . . . . . . . 21

Decker, G. J. . . . . . . . . . . . 17

de Laguna, $w . \ldots \ldots \ldots \ldots \ldots . \ldots . . \ldots 52$

Delano, J. M. . . . . . . . . . . 17, 18

Demiray, G. ............. 44

Dempsey, J. C. . . . . . . $\ldots \ldots \ldots \ldots \ldots$

Dempsey, T. ............. 26

Dennis, B. R. . . . . . . . . . . . . 27

Denoo, S. . . . . . . . . . . 20, 34

Denver Well Logging Society . . . . . 20, 44

Desai, K. P. . . . . . . . . . 7, 10, 20, 39

Desbrandes, R. . . . . . . . . 3, 8, 11

deVergie, P. C. . . . . . . . . 14, 15

DeVries, M. R. . . . . . . . . . 9, 43

deWaal, P. J. . . . . . . . . . . . . . . . 17

Dewan, J. T. . . . . . . . 21, 34, 43

Diad'kin, I. G. . . . . . . . . . 23

Dietl, H. . . . . . . . . . . 8

Dillingham, M. . . . . . . . . 48

Dines, K. A. . . . . . . . . . . . 32

Dobecki, T. L. . . . . . . . . . . 20

Dodd, P. H. . . . . . . . . 8, 22, 23

Doh, C. A. . . . . . . . . . . .
Page

Doig, R. . . . . . . . . . . 25

Dolezal, G., Jr. . . . . . . . . . . 39

Doll, H. G. .......... 8, 30, 44, 47

Donovan, w. S. . . . . . . . . . . 21

Dougherty, E. E. . . . . . . . . 27

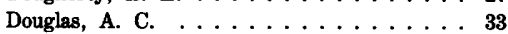

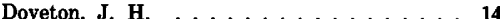

Dowdle, w. L. . . . . . . . . 49

Dreiling, L. A. . . . . . . . . . 35

Dresser Industries . . . . . . . . . 32

Droschak, D. M. . . . . . . . . . . 3

Drost, W. . . . . . . . . 29, 50

Droullard, R. F. . . . . . . . . . . 22, 23

Duda, J. R. . . . . . . . . . . 8

Dudgeon, C. R. . . . . . . . . . . . 19

Duesterhoeft, W. C., Jr. . . . . . . . . . 31

Duffey, D. . . . . . . . . . 25, 37

Dullien, F. A. L. . . . . . . . . . . 44

Dumanoir, J. L. . . . . . . 17, 23, 31, 40, 44 Dumestre, A. C. . . . . . . . . . 18

Duran, $0 . \ldots \ldots \ldots \ldots \ldots \ldots$

Duray, J. R. . . . . . . . . . . . . 22

Dyck, A. V. . . . . . . . . . . 8, 18

Dyck, J. H. . . . . . . . . . . 8

Dziallas, J. W. . . . . . . . . . . . . . . . . . . 49

\section{$\mathbf{E}$}

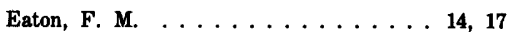

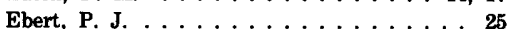

Edgson, J. J. $\ldots \ldots \ldots \ldots \ldots$

Edmundson, H. N. . . . . . . . 8

Edwards, J. M. . . . . . . 8, 13, 23, 34, 50

Edwards, L. M. . . . . . . . . . . 8

Eggers, D. E. . . . . . . . . . . . 52

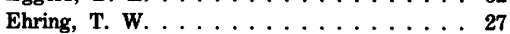

Eldridge, J. S. . . . . . . . . . 25

El-Kady, A. . . . . . . . . . . 25, 37

Elkington, P. A. S. . . . . . . . . . 34

Elliott, D. G. . . . . . . . . . . 27

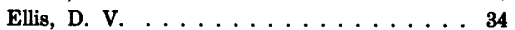

Ellithorpe, J. E. . . . . . . . . . . 17

Emerson, D. W. . . . . . . . . . . . 8, 44

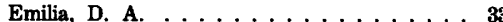

Engelke, C. P. . . . . . . . . 43

Engesser, F. C. . . . . . . . . 37

Enniss, D. 0. . . . . . . . . . . 27

Enrique, H. J. . . . . . . . . . . . 34

Erchul, R. A. . . .......44, 44

Ershaghi, I. . . . . . . . . . . 27

Etnyre, L. . . . . . . . . . . 20

Evans, H. B. . . . . . . . . 2, 8, 14, 23,

$25,26,41,44$

Evans, J. R., Jr. . . . . . . . . . . 40

Evans, M. L. . . . . . . . . . . 25

Evans, R. D. . . . . . . . . . 20

Evans, W. M. . . . . . . . . . . . . . 16

Farrel, w. E. ............. 6

Farstad, A. J. . . . . . . . . . 32, 46

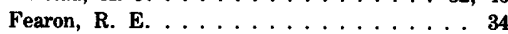

Fehler, M. C. . . . . . . . . . 3

Feigl, F. J. . . . . . . . . . .

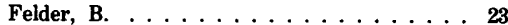

Feldman, I. I. . . . . . . . . . 34, 35

Ferm, J. C. . . . . . . . . . . 14

Ferronsky, V. I. . . . . . . . . . 9, 35

Fertl, w. H. . . . . . 9, 10, 13, 14, 25, 27, $28,40,41,42,43$, $46,49,53$

Fetzner, R. W. 46,49 , 
Feves, M.

Page

Ficke, J. F. . . . . . . . . . . 29, 30, 50

Filipek, S. . . . . . . . . . . . . 19

Filippov, E. M. . . . . . . . . 24

Findlay, D. C. . . . . . . . . . 39

Finklea, E. E. . . . . . . . . . 14

Fischer, J. S. . . . . . . . . . . . 19

Fishel, K. W. . . . . . . . . . . 23, 44

Fite, L. E. . . . . . . . . . . . . . 39

Fitzgerald, D. D. . . . . . . . . . 12, 18

Flaum, C. . . . . . . . . . . 37

Fleet, M. . . . . . . . . . . . 46

Fletcher, J. W. . . . . . . . . . . 37

Flores, R. M. . . . . . . . . . 13

Flynn, J. M. . . . . . . . . . . . 43

Folk, S. H. . . . . . . . . . . 29

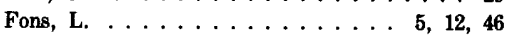

Foote, R. S. . . . . . . . . . . . 17

Ford, M. E. . . . . . . . . . 14

Ford, W. 0., Jr. ......... 32, 50

Foster, J. T. . . . . . . . . . . 17

Fowler, F. . . . . . . . . . . 22

Fowlis, W. W. . . . . . . . . . 19

Fraser, C. D. . . . . . . . . . 20

Freedman, R. .............. 17

Freeman, D. . . . . . . . . . . 41

Frischknecht, F. C. . . . . . . . 11

Froelich, B. . . . . . . . . . 3

Frost, E., Jr. . . . . . . . . . 14, 46, 48

Frost, N. . . . . . . . . . . . 48

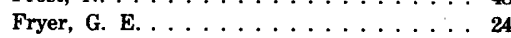

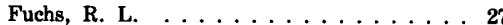

Fujinaga, Y. . . . . . . . . . . 23

Fuller, C. A. . . . . . . . . . 13

Furen, J. E. . . . . . . . . . . . 16

Furgerson, R. . . . . . . . . . . . . 28

\section{G}

Gale, J. E. . . . . . . . . . . . 30

Gallagher, M. J. . . . . . . . . . . . . 37

Gamson, B. W. . . . . . . . . . . 39

Gans, P. . . . . . . . . . . 14

Garb, F. A. . . . . . . . . . 9

Gardner, G. H. F. . . . . . . . . . 3

Gardner, J. S. . . . . . . . . . . 17, 23, 26

Gardner, R. P. . . . . . . . . . 23, 35

Gardner, W. . . . . . . . . . . . 35

Gardner, W. H. . . . . . . . . . . . 23, 33

Gartner, J. E. . . . . . . . . . . . 18, 21

Gaspar, E. . . . . . . . . . . . 50

Gauntt, J. C.

Gaur, R. S.

Gay, N. C.

Gaymard, $R$.

Gearhart Industries

Gearhart Owen International . . . . . . . 49

Geophysical Survey Systems . . . . . . 43

George, D. D.

George, E. R.

Geyer, R. L.

Ghaemian, S.

Gianzero, S. C.

Gill, D. . . . . . . . . . . . . 2

Gilreath, J. A.

Ginn, W. G.

Givens, W. W.

Gladwin, M. T.

Glanville, C. R.

Glenn, E. E.

Glenn, W. E.
Gobran, B. D. . . . . . . . . . . . 4

Godbey, J. J. . . . . . . . . . . 33

Godbey, J. K. . . . . . . . . . . . . 19

Goldberg, I. . . . . . . . . . . . . 35

Goldman, D. . . . . . . . . . . . . 29

Goldman, L. H. . . . . . . . . . . 25

Gomez-N, P. . . . . . . . . . . . 10

Gondouin, M. . . . . . . . . . 47

Gordon, E. . . . . . . . . . . . 17

Gorshkov, G. V. . . . . . . . . . . 38

Goryunov, I. I. . . . . . . . . . 44

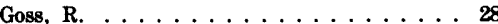

Gowd, T. N. . . . . . . . . . 3, 20

Grady, D. E. . . . . . . . . . 5

Granberry, R. J. . . . . . . . . 16, 22

Grasty, R. L. . . . . . . . . . . . 25

Gratsinskiy, V. G.

Graves, R. W.

Gray, D. A.

.. 3

$\ldots \ldots \ldots \ldots 1,20$

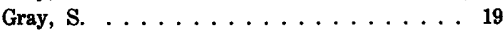

Greacen, E. L. . . . . . . . . . 35

Green, M. J. . . . . . . . . . . . . 19

Greenfield, R. J. . . . . . . . . . 30

Greenkorn, R. A. ............6

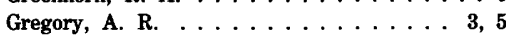

Griffiths, D. H. ............ 30

Grijalva, V. E. ........... 2

Grine, D. R. . . . . . . . . . . 3

Grisak, G. E. . . . . . . . . . . 52

Gritzner, M. L. . . . . . . . . . . . . 37, 39

Grose, L. T. . . . . . . . . . . 31

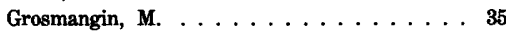

Gross, F. . . . . . . . . . . . . . . . . . . . . .

Groult, J. . . . . . . . . . . . 42

Grubb, R. N. . . . . . . . . . 44

Guberman, Sh. A. . . . . . . . 37

Gullyev, C. . . . . . . . . . . . . . 39

Guy, J. 0. . . . . . . . . . . . . 3, 35

Guyod, H.

$9,11,30,32$,

$44,47,49$

\section{H}

Haanschoten, G. W. . . . . . . . . 3, 44

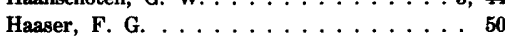

Haccoun, A. .......... 36

Hagstrum, J. T. . . . . . . . . 31

Haines, B. M. . . . . . . . 8, 44, 47

Haji-Shafie, M. . . . . . . . 47

Hale, L. A. . . . . . . . . . . . 22

Halevy, E. . . . . . . . . 50,51

Hall, E. G.

Hall, H. E.

50,51
34

Hall, J. E. . . . . $\ldots \ldots \ldots \ldots \ldots \ldots \ldots$

Hall, J. D. . . . . . . . . . . 15

Hallenburg, J. K. . . . . . 17, 22, 27, 32, 47

Hallock, W.

Hammack, G. W. . . . . . . . 9, 40, 53

Hamp, T. A. . . . . . . . . . . 43

Hancock, R. L. . . . . . . . . 17

Handy, L. L. . . . . . . . . . . 27

Hannah, J. L. . . . . . . . . . . . 28

Hansen, H. J.

Hanson, J. C.

Hanson, M. E.

Harms, J. C.

Harris, M. H.

Hartley, K. B. . . . . . . . . . .

Hartline, R. E. . . . . . . . 31

Haskell, R. E. . . . . . . . . . . 8

Hassen, B. R.

Hauck, A. M., III

Hauser, V. L.
Page

Hawkins, w. K. . . . . . . . . . 9, 22

Hayes, D. W. . . . . . . . . . 16, 23

Heacock, J. G., Jr. . . . . . . . . . . 23

Head, M. P. . . . . . . . . . 14, 23

Healy, J. H. . . . . . . . . . . . . 4, 21, 31

Hearst, J. R. . . . . . . . . 9, 23, 29, 35

Heath, R. L. . . . . . . . . . 25

Heflin, H. D. . . . . . . . . 9, 25

Heflin, J. D. . . . . . . . . . . 20

Heintz, K. 0. . ............ 29

Heise, H. . . . . . . . . . . . . . 9

Helander, D. P. . . . . . . . 3, 9, 18, 44, 45

Hempkins, W. B. . . . . . . . . 39, 47

Henderson, G. J. $\ldots \ldots \ldots \ldots \ldots \ldots \ldots$

Henry, J. D. . . . . . . . . . . . 47

Hensel, w. M. . . . . . . . . . . . 16

Henson, W. L. . ........... . .

Hepp, V. ................ 18

Herkelrath, w. N. .......... 23

Herolz, R. A. . . . . . . . . . 5

Herrick, R. C. . . . . . . . . . 39

Hertel, E. S., Jr. . . . . . . . . . . 51

Hertzog, R. C. . . . . . . . . 26, 38

Heseldin, G. M. . . . . . . . . . . 47

Heslop, A. . . . . . . . . . . 22, 32

Hess, A. E. . . . . . . . . . . 19

Hickman, J. B., Jr. . . . . . . . . 37

Hickman, S. ................ 48

Hicks, B. . . . . . . . . . . . 23

Hilchie, D. W. . . . . . . 9, 11, 12, 21,

$38,43,44$

Hill, D. A. . . . . . . . . . . 31

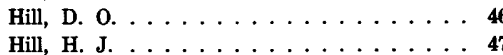

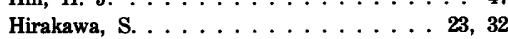

Hite, R. J. . . . . . . . . . . 8, 47

Hoang, V. T. ............ 49

Hobson, G. D. . . . . . . . . . 39

Hodges, H. D. . . . . . . . . . 22

Hodson, G. M. . . . . . . . . . . 40

Hoffard, S. H. . . . . . . . . . .

Hoffman, F. ................... 16

Hoffman, G. L. . . . . . . . 13

Hoffman, G. W. ............ 43

Hohman, G. W. . . . . . . . . 33

Holgate, M. M. . . . . . . . . 35

Hollenbach, R. E. . . . . . . . . . 5

Holser, W. T. . . . . . . . . . 44

Holt, O. R. . . . . . . . . . 18

Holter, E. L. . . . . . . . . . 50

Honea, C. . . . . . . . . . . 12

Hooper, L. J. . . . . . . . . . . 49

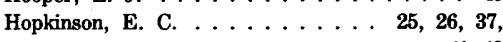

Horan, J. R. . . . . . . . . . 52

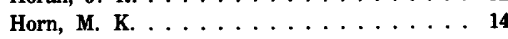

Horonjeff, R. .......... 35

Horton, J. H. ............ 34

Horvath, S. B. . . . . . . . . . 14

Hoskins, E. R. . . . . . . . . 48

Hossin, A. ............ 9, 40

Hottmann, C. E. . . . . . . . . 27, 42

Housley, R. M. . . . . . . . . 44

Houston, W. N. ............ 3

Howard, A. Q., Jr. . . . . . . . . 31

Howell, E. P. . . . . . . . . . . . 39, 49

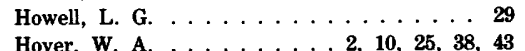

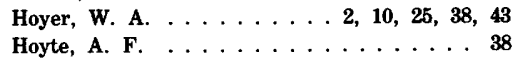

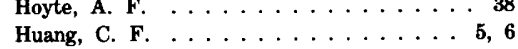

Hubbert, M. K. . . . . . . . . 30

Hughen, R. L. . . . . . . . 27

Hulen, J. B. . . . . . . . . . . . 27

Humphreys, D. R. ......... 43 
Hunter, J. A. $\ldots \ldots \ldots \ldots \ldots \ldots, 6$

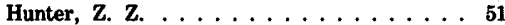

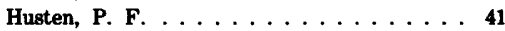
Hutchins, J. S. $\ldots \ldots \ldots \ldots \ldots \ldots \ldots$

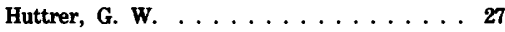
Hynes, S. D.

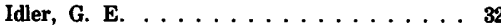

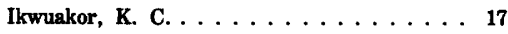
Ingram, D. S. . . . . . . . . . . Institut Francais du Petrole . . . . . . . 33 International Atomic Energy Agency . . . . 9 9 Isaacson, R. E. Isenhour, T. L. Itoh, $\mathrm{T}$.

Jack, R. S

Jackson, J. A. $\ldots \ldots \ldots \ldots \ldots \ldots \ldots \ldots \ldots$ Jackson, P. D. . . . . . . . . .

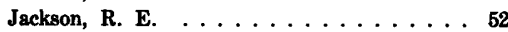

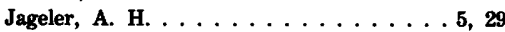
Jain, M. . . . . . . . . . . 25

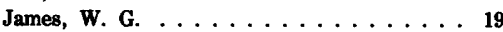
Jameson, J. B. . . . . . . . . . 38 Jankowsky, w. . . . . . . . . . Janzer, V. J. . . . . . . . . . . 52

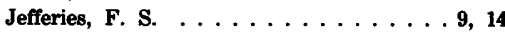
Jenkins, J. C. . . . . . . . . . . 9 Jenkins, R. E. . . . . . . 16, 22, 23, 41, 50

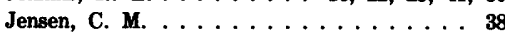
Jensen, D. H. . . . . . . . . . 43 Jensen, R. D. . . . . . . . . 29 Jester, W. A. . . . . . . . . . . 38 Johns, E. . . . . . . . . . . . 46, 49 Johns, S. E. . . . . . . . . . . . . 49 Johnson, A. I. . . . . . . 9, 29, 32, 35, 46

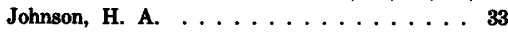
Johnson, H. M. . . . . . . . . . . 9, 14, 44 Johnson National Drillers Journal . . . . . 45 Johnson, R. K. . . . . . . . . . 27, 42

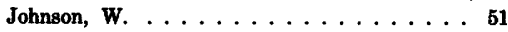
Johnson, W. M., Jr. . . . . . . . . 12 Johnston, D. H. . . . . . . . . . 6

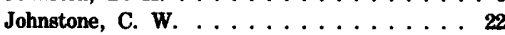
Jones, A. H. . . . . . . . . . . . . 2, 3, 6 Jones, B. . . . . . . . . . . . . 9 Jones, B. R. . . . . . . . . . . . . . . 29 29

Jones, 0. R. . . . . . . . . . . . 7 Jones, P. H. . . . . . . . 9, 27, 29, 45, 52 Jorda, R. M. . . . . . . . . . . . . 16

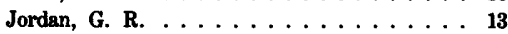
Josyln, C. D. . . . . . . . . . 49

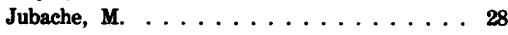

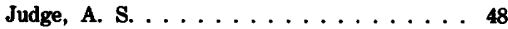

Juprasert, S. . . . . . . . . . . 28

\section{K}

Kading, H. W.

19, 49

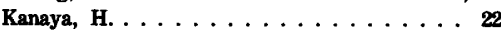

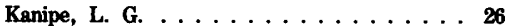

Kansara, M. . . . . . . . . 24

Karaoglan, E. I. . . . . . . . . . . . 38

Karaoguz, D. . . . . . . . . . . 44

Kasameyer, P. W. . . . . . . . . 29, 35

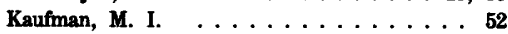

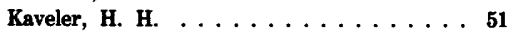

Keech, R. W. . . . . . . . . . Keen, D. . . . . . . . . . . 42
Keener, M. H. L. . . . . . . . . . 14 Kehrman, R. F. . . . . . . . . . 21

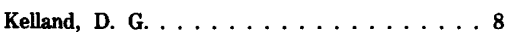
Kelldorf, W. F. N. . . . . . . . . . 51 Keller, G. V. . . . . . 9, 11, 16, 31, 45 Keller, H. H.

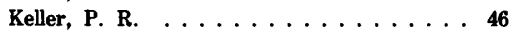
Kelley, D. R. . . . . . . . . . . 9

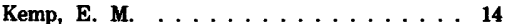

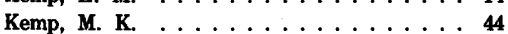
Kempton, N. H. . . . . . . . . . 13

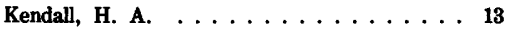
Kendall, K. K. . . . . . . . . . . . 5 Kessler, C. . . . . . . . . . . . . 2 21 Keys, W. S. $5,6,7,8,10,11$ $15,17,21,25,28,30,31$ $32,38,46,48,51,52$

Khalevin, N. I.

Khanin, A. A.

Khelil, C. A. . .

Khristianova, L. A. . . . . . . . . . 24

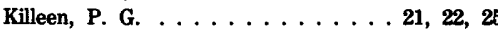

Killion, H. W. . . . . . . . . 22

Killpack, T. J. . . . . . . . . . . 14

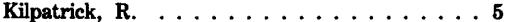

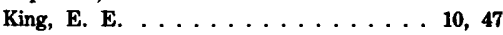

King, M. $\mathbf{s .} \ldots \ldots \ldots \ldots \ldots \ldots \ldots 4,21$

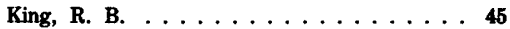

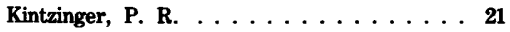

Kirkham, D. . . . . . . . . 35

Kirkpatrick, J. R. . . . . . . . 10

Kithas, B. A. . . . . . . . . .

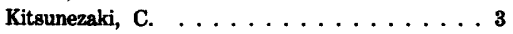

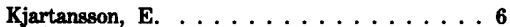

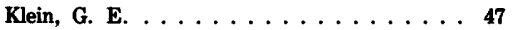

Klett, R. D.

Knopoff. L.

$12,15,17$

Knox, C. C.

Koelle, A. R.

$\ldots 21$

Koepf, E. H. $\ldots \ldots \ldots \ldots \ldots \ldots 16$, 50

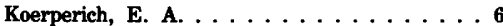

Kohout, F. A.

Koithara, J.

Koizumi, C. J. . . . . . . . . . . .

Kok, K. D.

Kokesh, F, P. $\ldots \ldots \ldots \ldots \ldots$

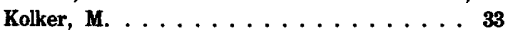

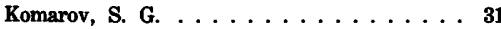

Konen, C. E.

Kosanke, K. L.

Koski, $\mathbf{K}$.

Kotov, P. T. .

Kovach, R. L.

Kowalski, J. J.

Kozik, H. G. .

Kratz, H. R.

Kreft, A. .

Krige, L. J.

Kriz, G. J.

Krueger, W. C. ,Jr.

Krug, J.

Krygowski, D.

Kukharenko, N. K

Kulinkovich, A. E.

Kumar, J.

Kumar, R. M. . . . . . . . 21, 45

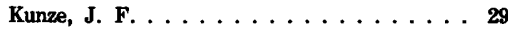

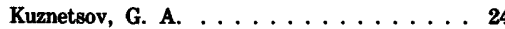

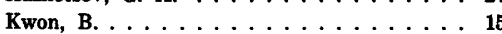

\section{L}

Labo, J.

Ladeira, F. L. .

Lafferty, R. H.,Jr. $\ldots \ldots \ldots \ldots \ldots \ldots \ldots$ 51

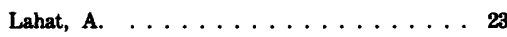

Lahman, H. S. . . . . . . . . 31

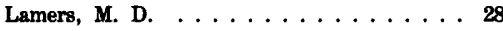

Lamont, $\mathbf{N} . \ldots \ldots \ldots \ldots \ldots$

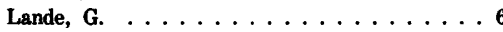

Landstrom, $0 . \ldots \ldots \ldots \ldots \ldots$. . . 25, 38

Landt, J. A. . . . . . . . . . . . 21

Lane, R. A. . . . . . . . . . . . 27

Lane-Wells Company . . . . . . . . . 35

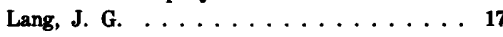

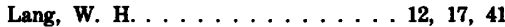

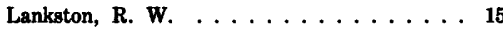

Lao, C. . . . . . . . . . . 31, 45

Lara, J. M. . . . . . . . . . . . 223

Larionov, v. v. . . . . . . . . 22

Latishova, M. G. . . . . . . . . 31

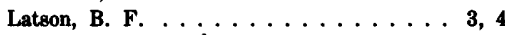

Lau, J. s. $0 . \ldots \ldots \ldots \ldots \ldots \ldots \ldots 48$

Laughlin, A. W. . . . . . . . 26, 29

Lauletta, J. F. . . . . . . . . 42

Lauzon, A. F. . . . . . . . . . 25

Lavers, B. S. . . . . . . . . 10

Lawal, A. S. . . . . . . . . . 5

Lawrence, H. W. . . . . . . . . 7

Lawrence, T. D. . . . . . . . . 38, 43

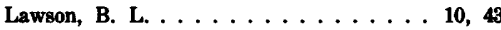

Lebourg, M. . . . . . . . . . . 10

Lebreton, F. . . . . . . . . . . 6, 10

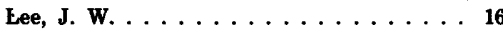

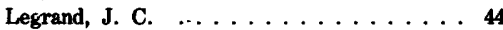

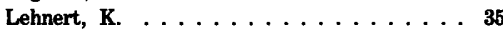

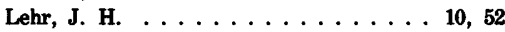

Leon, P. A. . . . . . . . . . . . 28

Leonardson, E. G. . . . . . . . . 11

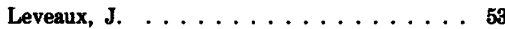

Lewis, D. C. . . . . . . . . 51

Lichtenberger, G. J. . . . . . . . . . 51

Lin, w. . . . . . . . . . 40

Lindseth, R. 0. . . . . . . . . . . 10

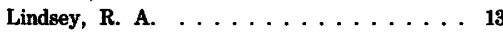

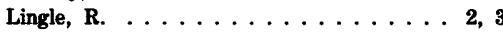

Lishman, J. R. . . . . . . . . . . 45

Liu, $0 . \ldots \ldots \ldots \ldots \ldots \ldots \ldots \ldots$

Livnat, R. . . . . . . . . . 23

Ljunggren, K. . . . . . . . 25

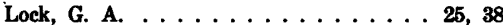

Locke, s. . . . . . . . . . . 12, 41

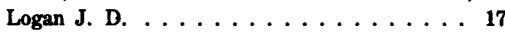

Logan, M. H. . . . . . . . . . 15

Loren, J. D. . . . . . . . . . . . 39

Lovborg, L. . . . . . . . . . . . 25

Loveless, G. W. . . . . . . . . . . . 5

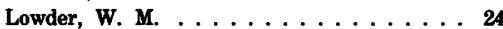

Lowe, R. B. . . . . . . . . . . 20 20

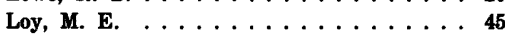

Lucas, D. R. . . . . . . . . . 46

Lucia, F. J. . . . . . . . . . 41

Lukavchenko, P. I. . . . . . . . . . 29

Lukes, J. . . . . . . . . . . . . . 10

Lynch, E. J. . . . . . . . . . . . 12

Lyons, D. J. . . . . . . . . . . . 28

Lyshko, N. A. . . . . . . . . . . 41

Lysne, P. C. . . . . . . . . . . . . . 17

Lytle, R. J. $\ldots \ldots \ldots \ldots 6,18,21,32$

\section{$M$}

MacCary, L. M. . . . . 10, 12, 15, 20, 32, 46 MacDonald, G. J. F. . . . . . . . . 48 Machan, R. . . . . . . . . . 44

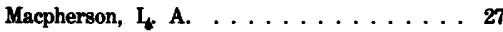

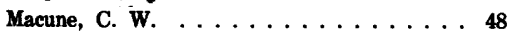

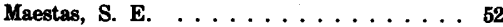

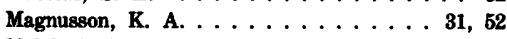

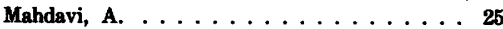


Mairhofer, J. . . . . . . . . . . . . 51

Majerezyk, J. . . . . . . . . 35

Mannon, R. C.

Marchant, L. C

12,16

Mardock, E. S.

Maricelli, J. J.

Marine, I. W.

Marquis, G. L.

Marr, H. E.

Marsden, S. S., Jr.

Marshall, A. G. B.

Martin, $M$.

Martinez, S. J.

Massey, G. R.

Mathews, M. A.

Matiisen, A. . . . . .

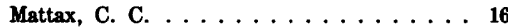

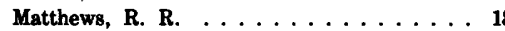

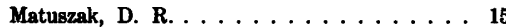

Matveev, B. K. . . . . . . . . . 19

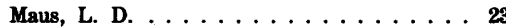

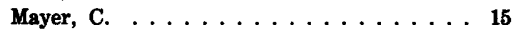

Mayer, R., Jr. . . . . . . . . . . . 23, 46

McCall, C. M. . . . . . . . . . . 47

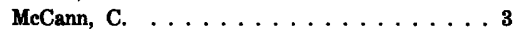

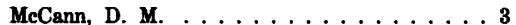

MeCardell, W. M. . . . . . . . . 46

MeConnell, B. V. . . . . . . . . . . 21

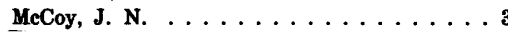

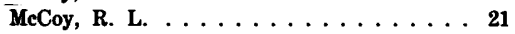

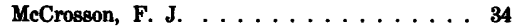

MeCulloh, T. H. . . . . . . . . 29

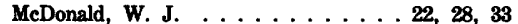

McDonnell, W. R. . . . . . . . . . . . 35

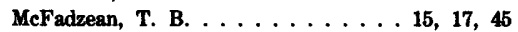

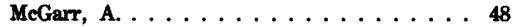

MeGhee, J. . . . . . . . . . . 20

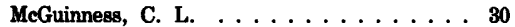

McHenry, J. R. . . . . . . . . 35

McKenzie, C. $\mathbf{K} . \ldots \ldots \ldots \ldots \ldots \ldots$

MeKinlay, P. F. . . . . . . . 35

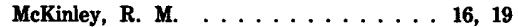

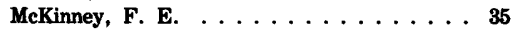

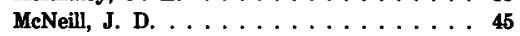

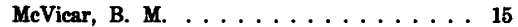

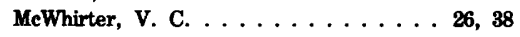

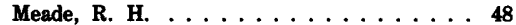

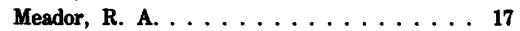

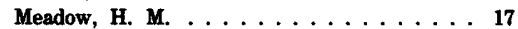

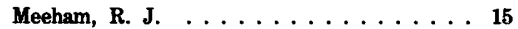

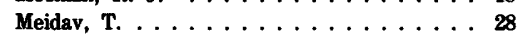

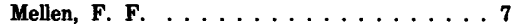

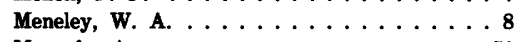

Mercado, A. . . . . . . . . 51

Mercier, v. J. . . . . . . . . . . 41

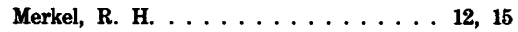

Meunier, D. . . . . . . . . . 40

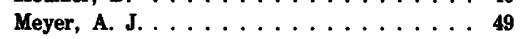

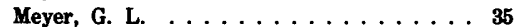

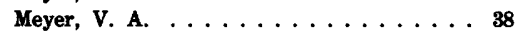

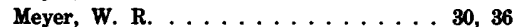

Miesch, E. P. . . . . . . . . 16

Mikaelyan, s. S. . . . . . . . . . 41

Mikhailovskii, v. N. . . . . . . 44

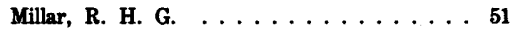

Millard, F. S. . . . . . . . . 45

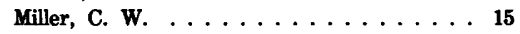

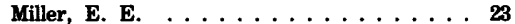

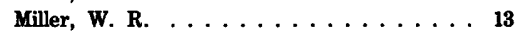

Millett, M. R. . . . . . . . . 33

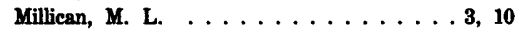

Mills, w. R., Jr. $\ldots \ldots \ldots \ldots$ 7, 34, 35,

Misk, A. .......... 10

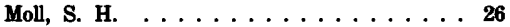

Monaghan, R. . . . . . . . 37

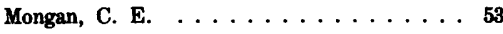

Monkhouse, R. A. . . . . . . . 46

Montadert, L. . . . . . . . . . . . 42

Montana Bureau of Mines and Geology . . . 13

Mooney, R. T., III . . . . . . . . . 32

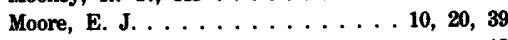

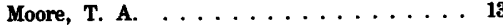

Mooring, J. F. . . . . . . . . 36

Moran, J. H. $\ldots \ldots \ldots \ldots \ldots \ldots$ 10, 15, 18

Morris, B. P. $\ldots \ldots \ldots \ldots \ldots 4$ 48, 49, 51

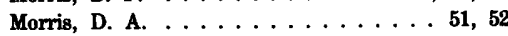

Morris, R. L. . . . . . . 3, 34, 40, 41, 46

Morris, T. S.

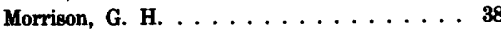

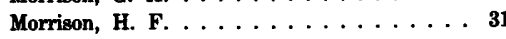

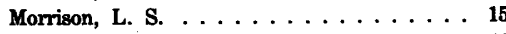

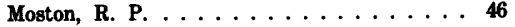

Mott, W. E.

26,51

Mougne, M. L.

Moussie, C.

Moxham, R. M. . . . . . . . 26, 38

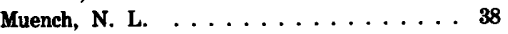

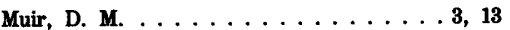

Muller, D. C. $\ldots \ldots \ldots \ldots \ldots \ldots \ldots$. 33

Mullins, J. E. . . . . . . . . . . 48

Murphy, H. D. $\ldots \ldots \ldots \ldots \ldots \ldots$ 28, 49

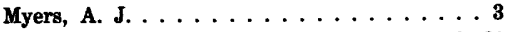

Myung, J. I. . . . . . . . . . . . 3, 18, 21

\section{$\mathbf{N}$}

Nace, R. L. . . . . . . . . . 52

Nakano, Y. . . . . . . . . . . 40 40

Nakhabtsev, v. S. . . . . . . . 38

Narasimhan, T. $\mathbf{N} . \ldots \ldots \ldots \ldots \ldots$

Nargolwalla, S. S. . . . . . . . . . 32

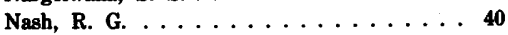

Nations, J. F. . . . . . . . . . 6

Neal, J. K. . . . . . . . . 31

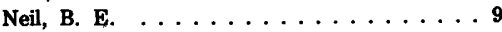

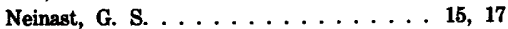

Nelligan, w. B. . . . . . . . 36, 43

Nelms, C. A. . . . . . . . . . 13

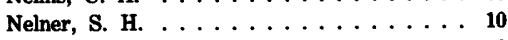

Nelson, P. H. . . . . 10, 22, 30, 31, 36, 52

Nettleton, K. A. . . . . . . . 25

Neuman, C. H. . . . . . . . . . 39

Newcome, R., Jr. . . . . . . . . 20 20

Nielsen, D. R. . . . . . . . . . 23, 37

Nielson, D. L. . . . . . . . . . . . 24, 27

Nielson, H. L. . . . . . . . . . . 26

Nir, A ............ 50

Nix, D. W. . . . . . . . . 26

Nolte, E. . . . . . . . . . . 3

Nooteboom, J. J. . . . . . . . . . . . 17

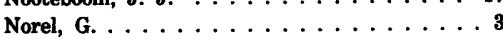

Norris, S. E. . . . . . . . . . 22

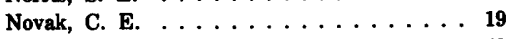

Nowak, R. J. . . . . . . . . . .49

Nur, A. M. . . . . . . . 3, 6

\section{o}

Oakes, T. W.

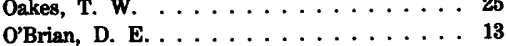

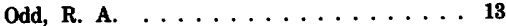

Odegaand, H. . . . . . . . . 21

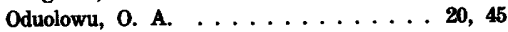

Offshore Service Technology . . . . . . 15

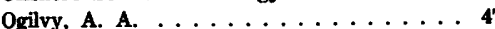

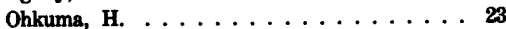

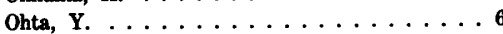

Oil and Gas Journal . . . . . . . . . 19, 33

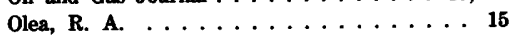

Olgaand, P. L. . . . . . . . . . 36

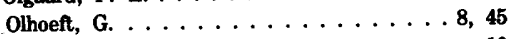

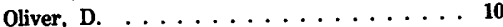

Oliver, J. R. . . . . . . . . . . 44

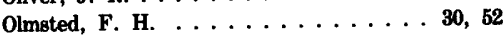

Olson, C. C. . . . . . . . . . 42

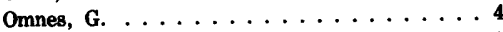

Onceseu, M. . . . . . . . . 50

Orswell, P. L. . . . . . . . . . 45

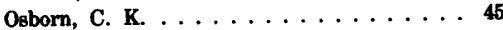

Oshier, E. H. $\ldots \ldots \ldots \ldots \ldots \ldots \ldots$ 48

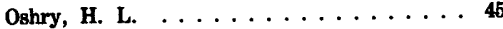

Osoba, J. C. . . . . . . . 24, 38, 41, 47

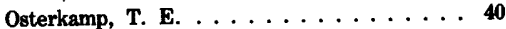

Ott, J. . . . . . . . . . 44

Ottinger, N. H. . . . . . . . 8

Overton, H. L. $\ldots \ldots \ldots \ldots \ldots$ 4, 5, 45, 47

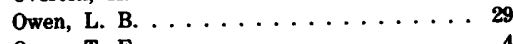

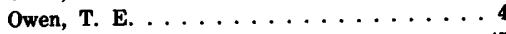

Ozcandarli, T. D. . . . . . . . 45

\section{$\mathbf{P}$}

Paap, H. J. $\ldots \ldots \ldots \ldots \ldots \ldots$ 36, 50, 51

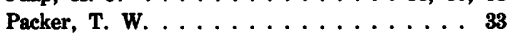

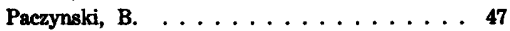

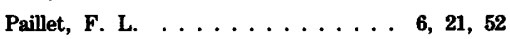

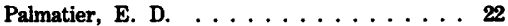

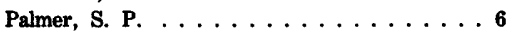

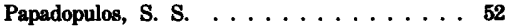

Parizek, R. R. . . . . . . . . 38

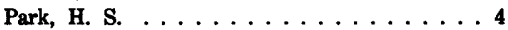

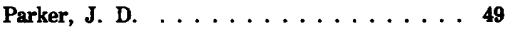

Parker, R. L. . . . . . . . . . 33

Parks, P. B. . . . . . . . . . . 34

Patchette, J. G. . . . . . . . 41, 48

Patten, E. P., Jr. . . . . . . . . . . . 19

Patterson, J. A. . . . . . . . . 15

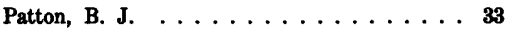

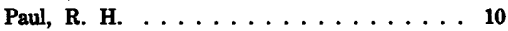

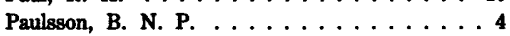

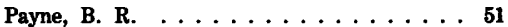

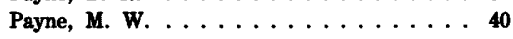

Peacock, D. R. . . . . . . . . 49

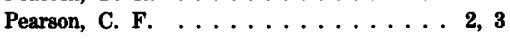

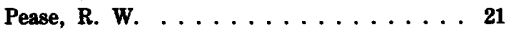

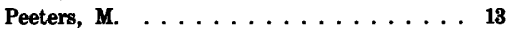

Pemberton, R. R. . . . . . . . 30, 31

Pennebaker, E. S., Jr. . . . . . . . . 49

Penny, s. J. . . . . . . . . . . . 42

Perez-Rosales, C. . . . . . . . . . 20

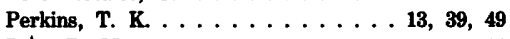

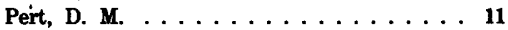

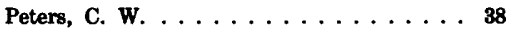

Peterson, F. L. $\ldots \ldots \ldots \ldots \ldots \ldots$ 31, 36, 45

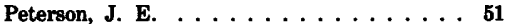

Petroleum Engineer . . . . . . . 36

Pettitt, B. E. . . . . . . 20

Pettitt, R. A. . . . . . . . 28

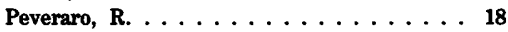

Philbin, P. . . . . . . . . 38

Pichugin, N. I. $\ldots \ldots \ldots \ldots \ldots \ldots$

Pickell, J. J. . . . . . . . . . . . 23

Pickett, G. R. . . . . . 4, 10, 12, 136, 13,

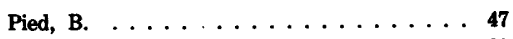

Pierce, C. 1. . . . . . . . . . 8, 20

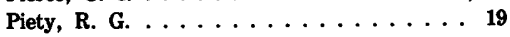

Pilkington, P. E. $\ldots \ldots \ldots \ldots \ldots \ldots \ldots$

Pilles, D. . . . . . . . . . . . 14

Pirie, G. $\ldots \ldots \ldots \ldots \ldots \ldots \ldots \ldots \ldots$

Pirson, S. J. . . . . . . . . 10, 12, 22, 31, 42,

$44,45,47$

Pittard, G. $\ldots \ldots \ldots \ldots \ldots \ldots \ldots \ldots \ldots \ldots \ldots \ldots \ldots$
Pittman, D. $\ldots \ldots \ldots \ldots$ 
Pivovarov, V. T'.

Piwinskii, A. J.

Plasek, R. E.

Pointer, R.

Poland, J. F.

Poley, J. P.

Pollard, D. E.

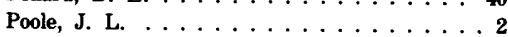

Porter, C. R. . . . . . . . . 20, 41

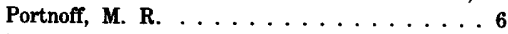

Potter, R. M. . . . . . . . . . 28

Poupon, A. . . . . . . 10, 18, 32, 45,

47,53

Powell, N. J.

Powell, N. J. $\ldots \ldots \ldots \ldots \ldots \ldots \ldots \ldots \ldots$
Power, D. v. $\ldots \ldots \ldots \ldots \ldots \ldots \ldots \ldots$

Powers, R. P. . . . . . . . . . 26

Pranglin, J. A. . . . . . . . . . 45

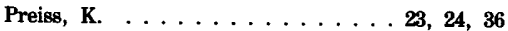

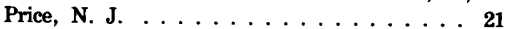

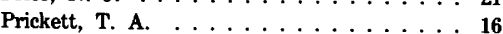

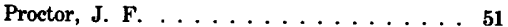

Przewlocki, K. . . . . . . . . 36

\section{Q}

Quirein, J. A. 26

\section{$\mathbf{R}$}

Rabe, C. L. . . . . . . . Rabson, w. R. . . . . . . . 36

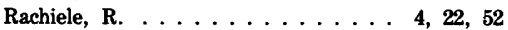
Rader, D. . . . . . . . . . . 6

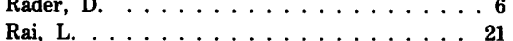
Raiga-Clemenceau, J. . . . . . . . . . . 20 Ralston, D. R. . . . . . . . . . 36 Ramananantoandro, R. . . . . . . . 6 Ramey, H. J., Jr. . . . . . . . . . . 46 Ramirez, A. L. . . . . . . . . . . 21 Randal, R. R. . . . . . . . . 43 Randall, W. $10,41,45$ Ransom, R. C. Rasmus, J. C. . . . . . . . . . . 21 Rasmussen, N. F. . . . . . . . . 29 Ratliff, J. R. . . . . . . . . . . . 15

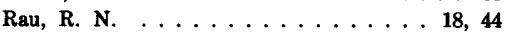

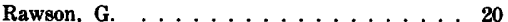
Ray, J. W. . . . . . . . . . 35 Raymer, L. L. . . . . . . 2, 8, 10, 40, 41 Raymond, J. R. . . . . . . . . . . 52 Reardon, P. . . . . . . . . . . 28

Rechtien, R. D. . . . . . . 4, 6 Redford, W. H. . . . . . . . . 41

Reeder, H. 0. . . . . . . . . . 7

Reiss, L. H. . . . . . . . . . . 42

Renkin, J. H. . . . . . . . . . 38

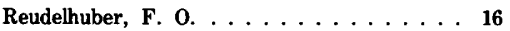

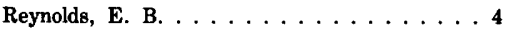

Rhodehamel, E. C. . . . . . . . . 10

Rhodes, D. F. . . . . . . . . . 26

Richardson, J. E. . . . . . . . 41, 51

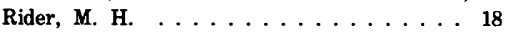

Riddle, G. . . . . . . . . . 6

Riecker, R. E. . . . . . . . . . 27

Rieke, H. H., III . . . . . . . . . 25, 40

Rigby, F. A. . . . . . . . . 21, 28

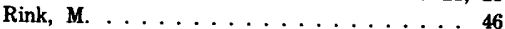

Ritch, H. J.

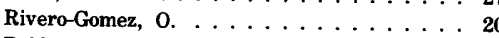

Robb, W. A. . . . . . . . . . . . 39

Robbins, S. L. . . . . . . . 24, 29

Roberts, H. V. . . . . . . . . . . 15

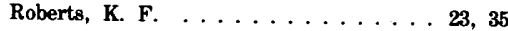

Roberts, W. F., Jr. . . . . . . . . . 33

Robertson, A. S. . . . . . . 11, 20

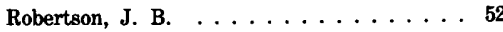

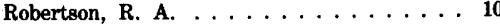

Robinson, A. E. . . . . . . . . . 19

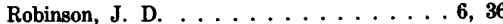

Robinson, w. S. . . . . . . . . . 4, 11

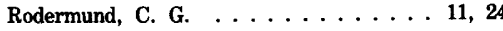

Rodriquez, A. R. . . . . . . . 45

Roesner, R. E. . . . . . . . . . 51

Roetman, E. L. . . . . . . . . . . .

Roller, J. C. . . . . . . . . . . . 31

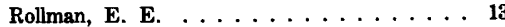

Roney, J. R. . . . . . . . . . . . 24

Rosen, R. L. . . . . . . 11

Ross, E. W. . . . . . . . . . . 28, 36

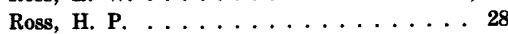

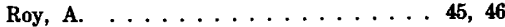

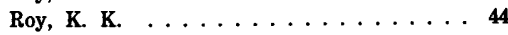

Rudman, A. J. $\ldots \ldots \ldots \ldots \ldots$ 15, 46

Ruedrich, R. A. . . . . . . . . 13

Rumble, R. C. . . . . . . . . . 19

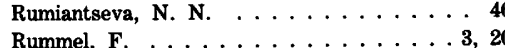

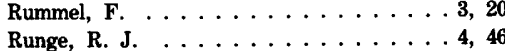

Russell, J. H. . . . . . . . . . . 41

Ryapolov, v. A. . . . . . . . . 31

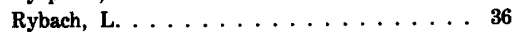

\section{S}

Sack, H. s. $\ldots \ldots \ldots \ldots \ldots \ldots \ldots$. 34 Salisch, H. A. . . . . . . 7, 11, 34

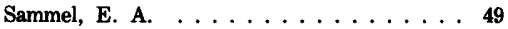
Samsahl, K. . . . . . . . . . 38

Samworth, J. R. . . . . . . . 13, 24

Samworth, R. J. . . . . . . . 24

Sanders, L. C. . . . . . . . . . 36

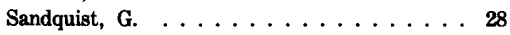

Sano, S. I. . . . . . . . . . . . 22

Sanyal, S. K. . . . . 12, 17, 27, 28, 42, 46 Sass, J. H. . . . . . . . . . . . . . 48

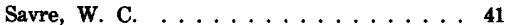

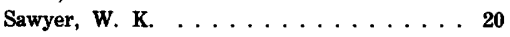
Sayer, S. . . . . . . . . . . . 28

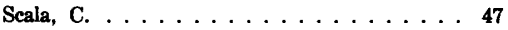

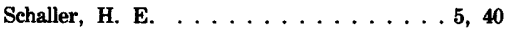
Schenewerk, P. A. . . . . . . . . 26 Schimschal, U. . . . . . . . 19, 26, 30, 40

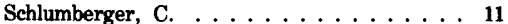
Schlumberger, M. . . . . . . . . . . 11 Schlumberger Well Surveying Corporation . 32, 42

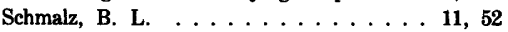
Schmidt, A. W. . . . . . . 13, 15, 17, 41

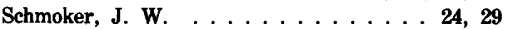

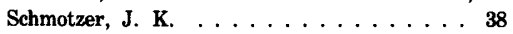

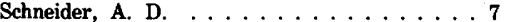
Schneider, R. . . . . . . . . 49 Schoenberg, M. . . . . . . . . . 4 Schoeppel, R. J. . . . . . . . . . . . 46 Schooner, L. G. . . . . . . . . . . 18

Schoonover, L. G. . . . . . . . . . 18, 42 Schopper, J. R. . . . . . . . . . . . 46

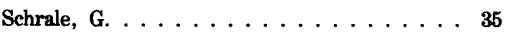

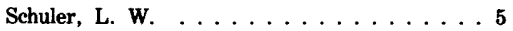

Schultz, A. L. . . . . . . . . . . . 12

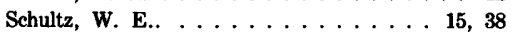
Schulze, R. P. . . . . . . . . . 14 Schuster, C. L. . . . . . . . . . 20 Scientific Software . . . . . . . . . 15

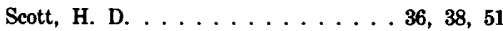

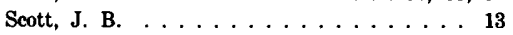

Scott, J. H. $\ldots \ldots \ldots 4,8,11,12,13,14$, $15,16,22,24,31$

Seeley, R. L.
Seeman, B. . . . . . . . . . . . 3 Seevers, D. $0 . \ldots \ldots \ldots \ldots \ldots \ldots$. 40

Segesman, F. F. $\ldots \ldots \ldots \ldots \ldots 11,36,47$

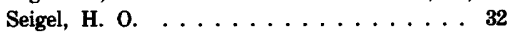
Seismic Service Corporation . . . . . . 4 Selecki, A. . . . . . . . . . . . 19 Sembodo, P. B. V. D. . . . . . . . . . 31

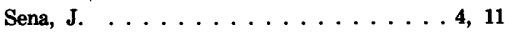
Senftle, F. E. . . . . . . . 25, 26, 36, 37,38

Serra, $0 . \ldots \ldots \ldots \ldots \ldots \ldots 26$

Seth, M. S. $\ldots \ldots \ldots \ldots \ldots \ldots$ 39, 49

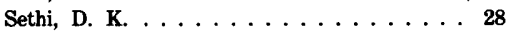

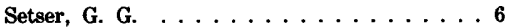

Shamey, L. J. . . . . . . . . 11, 46

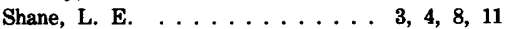

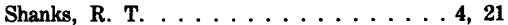

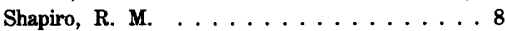

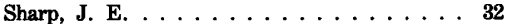

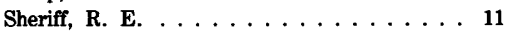

Sherman, H. . . . . . . . . 12, 34, 41

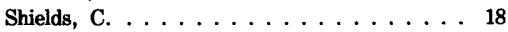

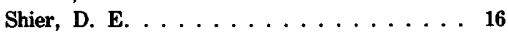

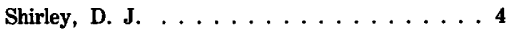

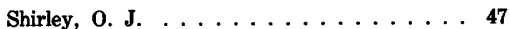

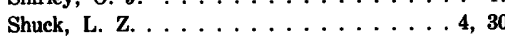

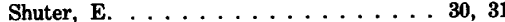

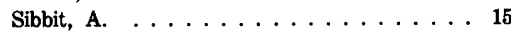

Siegfried, R. W. . . . . . . . . . 3, 6

Signor, D. C. $\ldots \ldots \ldots \ldots \ldots \ldots$ 7

Silva, J. B. C. . . . . . . . . . 33

Silva, P. . . . . . . . . . 47

Simard, G. L. . . . . . . . . . . 47

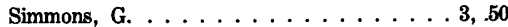

Simmons, R. W. . . . . . . . . . 17

Simpson, A. I. . . . . . . . . . . 34

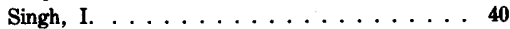

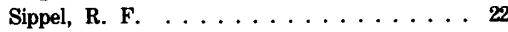

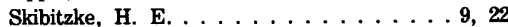

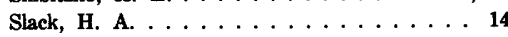

Slichter, C. S. . . . . . . . . . . . 19

Smedmor, w. J. . . . . . . . . . . 19

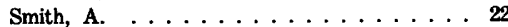

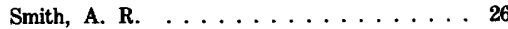

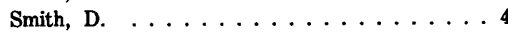

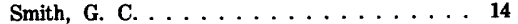

Smith, H. D., Jr. $\ldots \ldots \ldots \ldots \ldots 34,36,38$

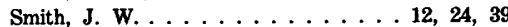

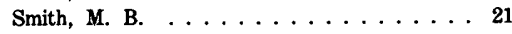

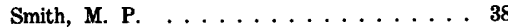

Smith, P. G. . . . . . . . . 6

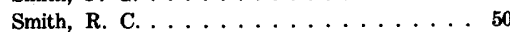

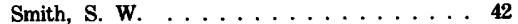

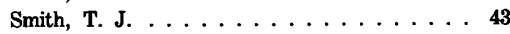

Smith, W. D. M. . . . . . . . . 3, 24, 35

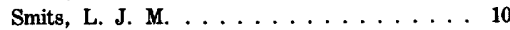

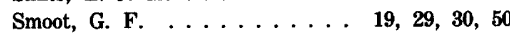

Snodgrass, J. J. . . . . . . . . . . 12

Snyder, D. D. . . . . . . . . . . . 12

Society of Professional Well Log

Analysts $\ldots \ldots \ldots \ldots \ldots \ldots \ldots \ldots \ldots$
Sokhranov, N. N. $\ldots \ldots \ldots \ldots \ldots \ldots \ldots \ldots$

Somerton, W. H. . . . . . . . . 48, 49

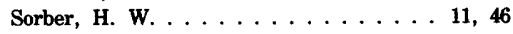

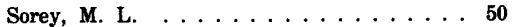

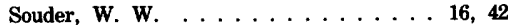

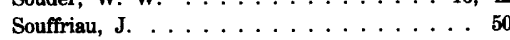

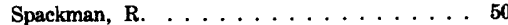

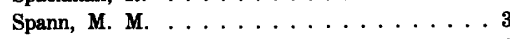

Spencer, J. W., Jr. . . . . . . . . . .6

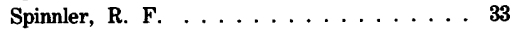

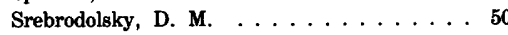

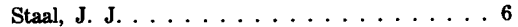

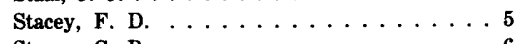

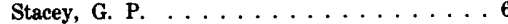

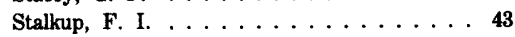


Staron, P. . . . . . . . . . 2 Stefansson, V. . . . . . . . . . . . ${ }^{\mathbf{2} 8}$

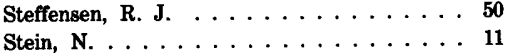

Steingrimsson, B. . . . . . . . . . 28 Steinman, D. K. . . . . . . . . . . 36, 38

Stephansson, 0. ........... 6

Stephen, W. F. . . . . . . . . . 12

Stephens, D. R. . . . . . . . . . . 40

Sterner, T. E. . . . . . . . . . 19

Stetyukha, E. 1. . . . . . . . . . 41

Stevens, H. H. . . . . . . . 29, 30, 50

Stevens, 0. D. . . . . . . . . . 17

Stieber, S. J. . . . . . . . . . 43

Stierman, D. J. . . . . . . . . 4, 21

Stoker, R. C. . . . . . . . . . 29

Stokoe, K. H. . . . . . . . . . 6

Stoll, R. D. . . . . . . . . . 6

Stone, F. A. . . . . . . . . . . 38

Stone, 0. L. . . . . . . . . . . . 34

Storm, E. . . . . . . . . . 48

Stouthamer, P. . . . . . . . . 34

Strabala, J. M. . . . . . . . . 2, 7

Stratton, E. F. ............ 44

Stratton, R. ............. 5

Strecker, I. . . . . . . . . . . 10

Stripling, A. A. . . . . . . . . . .

Stromswold, D. C. . . . . . . . . . . 26

Stroud, S. G. . . . . . . . . . . 13

Stuart, T. P. .............. 26

Suau, J. . . . . . . . . . 21, 30

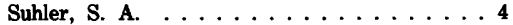

Sullivan, J. K. . . . . . . . . . 5, 28

Sun, R. J. . . . . . . . . . . . 5

Sundberg, K. ............ 46

Supe, C. ............... 2

Svenson, A. N. ............ 4

Swanson, B. F. ............ 16

Syms, M. C. . . . . . . . . . . 19, 29

Syms, P. H. . . . . . . . . . . . 19, 29

\section{$\mathbf{T}$}

Tait, D. B. . . . . . . . . 50

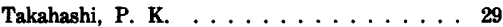

Tammemagi, H. Y. . . . . . . . . . 31

Tanguy, D. R. . . . . . . . . . 5, 11

Tanner, A. B. . . . . . . . 25, 26, 36, 38

Tanner, H. L. . . . . . . . . . . . . 35

Tarron, R. D. . . . . . . . . . . 14

Tate, T. K. .......... 11, 20

Tatham, R. H. . ..........4

Taylor, D. . . . . . . . . . . 24

Taylor, J. H. . . . . . . . . . 45

Taylor, K. $0 . \ldots \ldots \ldots \ldots \ldots \ldots \ldots$

Taylor, P. A. ............ 32

Taylor, T. A. . . . . . . . . . 52

Teasdale, W. E. . . . . . . . . . 29

Telford, w. M. . . . . $\ldots \ldots \ldots \ldots \ldots$

Thadani, S. G. . . . . . . . . . . 15

Theriod, J. C. . . . . . . . . . . 18

Thomas, E. C. . . . . . . . . . 16, 46, 47

Thomas, H. E. . . . . . . . . 12, 19, 24

Thomsen, H. S. . . . . . . . . . 31

Thompson, K. D. . . . . . . . . 42

Thompson, W. E. . . . . . . . . . 37

Thrasher, J. E.

Threadgold, $\mathbf{P}$.

$11,32,33,43$

Throop, W. H

Thurber, C. H.

Tibbetts, B. L.

Timko, D. J. . . . . . . . . . 4, 9, 27, 40, 42

Timur, A. . . . . . 4, 5, 11, 27, 39, 40

Tinch, D. H.
Tindell, w. A. . . . . . . . . . . . 31 Tittle, C. W. . . . . . . . . . 36, 51 Tittman, J. . . . . . . . 11, 24, 36, 41, 43 Tixier, M. P. . . . . 4, 11, 16, 31, 40, 41, $45,46,47,50$

Todd, B. E. . 27

Toksoz, M. N

$2,5,6$

Toth, J. C.

Towle, G. . . . . . . . . .

Traugott, M. $0 . \ldots \ldots \ldots \ldots \ldots$. . . . . 41

Traynor, B. V., Jr. . . . . . . . . 33

Trudell, L. G. . . . . . . . . . . 24

Trudgen, P. ............ 16

Truman, R. B.

Trunz, J. P., Jr.

TRW Systems Group

Tsang, P. B.

Tsukahara, $\mathrm{H}$.

Tsvetkov, 0. S. . . . . . . . . . 38

Tuman, V. S. . . . . . . . . 16

Turean, A. N., Jr. . . . . . . . . 46

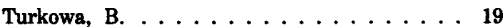

Turner, W. J. . . . . . . . . . . 42

Tyner, C. E. ............. 51

\section{$\mathbf{U}$}

Ullo, J. J. . . . . . . . . . . . . . 34, 36

Umbarger, C. J. . . . . . . . . 26

Upp, J. E. . . . . . . . . . . . . 13

U.S. Forest Service . . . . . . . . . 36, 37

U.S. Geological Survey . . . . . . . . . 13, 53

Utegenov, S. M. . . . . . . . . . . 37

Utkin, V. I. . . . . . . . . . . . 24

\section{V}

Vacquier, V.

van Baaren, $C$

van de Kamp, P. C. . . . . . . . . . 28

Van Orstrand, C. E. ........... 50

van Poolen, H. K. . . . . . . . 7, 20

Van Rooy, D. L. . . . . . . . . . . 19

Varvarin, G. B. . . . . . . . . . . 24

Veach, C. L. ............ 37

Veazey, M. J. ............. 43

Veneziani, I. I. . . . . . . . . . 11

Vercellino, W. C. . . . . . . . . . 16

Vesperman, F, A. . . . . . . . . . 19

Vetter, 0. J. ............. 51

Vincent, P. . . . . . . . . . . . 18

Vogel, C. B. . . . . . . . . . . . . 5

Vogiatzis, J. P. ............ 17

Von Gonten, W. D. . . . . . . . . . 47

Vonhof, J. A. . . . . . . . . . . 47

Vozoff, K. . . . . . . . . . . . 31

\section{W}

Wade, R. T

Wahl, J. S.

Wainerdi, R.

Wait, J. R.

Walker, E. B.

Walker, $\mathbf{T}$.

Wallace, W. E

Waller, W. C.

Wallis, G. R.

Walstrom, J. E.

Walter, F

Walter, J.

Walters, E. J.
Walton, w. C. . . . . . . . . . 16

Wang, G. . . . . . . . . . . . . 46

Ward, P. R. B. . . . . . . . . . . 19

Ward, s. H. . . . . . . . . . . 31

Warner, D. L. . . . . . . . . . . 52

Warpinski, N. R. ........... 21

Waters, K. H. ............. 6

Watson, J. T. .............. 26

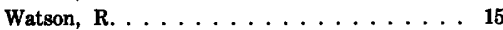

Watt, H. B. ............. 16

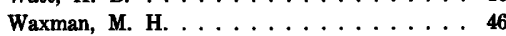

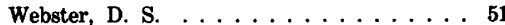

Webster, s. S. $\ldots \ldots \ldots \ldots \ldots \ldots$

Wedderburn, L. A. . . . . . . . . . 17

Weed, H. C. . . . . . . . . . . . 45, 46

Weeks, J. B. . . . . . . . . . . . . . . 39

Wehman, G. . . . . . . . . . . 52

Welder, F. A. . . . . . . . . . . . 39

Welex Division . . . . . . . . . . . 5, 32

Welhan, J. A. . . . . . . . . . . 30

Welker, D. . . . . . . . . . . . . 25

Wells, J. C. . . . . . . . . . . . . 16

Wells, L. E. . . . . . . . . . . . 12, 18

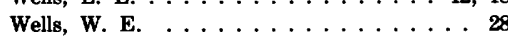

Wenner, C. G. . . . . . . . . . . . 38

West, F. G. . . . . . . . . . 21, 26, 29

West, G. F. . . . . . . . . . . 18

West, L. . . . . . . . . . . 26

Westaway, P. . . . . . . . . . 26

Westbrook, L. P. . . . . . . . . . 59

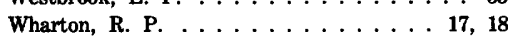

Wheatley, J. C. . . . . . . . . . . . 37

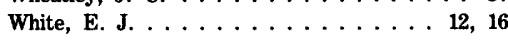

White, J. . . . . . . . . . . 30

White, J. E. . . . . . . . . . 5

Whittaker, A. H. . . . . . . . . 42

Wichmann, P. A. . . . . . 18, 26, 37, 39, 40

$41,42,4449$

Wiebenga, W. A. ........... 51

Wieland, D. R. . . . . . . . . . 46

Wiercinski, G. M. . . . . . . . . . 5

Wiley, B. F. . . . . . . . . . . 19

Wiley, R. . . . . . . . . . . . 5, 26, 32

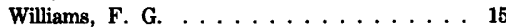

Williams, G. B. $\ldots \ldots \ldots \ldots \ldots \ldots \ldots$. $\ldots \ldots, 21$

Williams, J. S. . . . . . . . . . . . . 42

Willibrand, A. F. . . . . . . 46

Willis, D. G. . . . . . . . . . 30

Willis, M. E. ............ . 2

Wilshusen, R. C. . . . . . . . . 16

Wilson, B. F. . . . . . . . . . 37

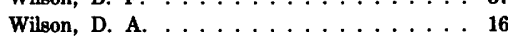

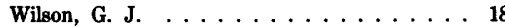

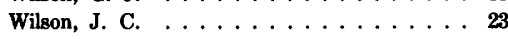

Wilson, L. G. . . . . . . . . . . 34

Wilson, R. D. ............ 26

Wilson, R. G. . . . . . . . . . . . 37

Winn, R. H. ............ 13, 37

Winnie, D. D. ............ 4

Winograd, I. J. . . . . . . . . . 52, 53

Winsauer, W. $0 . \ldots \ldots \ldots \ldots$

Winslow, J. D. . . . . . . . . 50

Witherspoon, P. A. . . . . . . . . 29

Witterholt, E. J. . . . . . . . 10, 19, 49, 50

Wogman, N. A. . . . . . . . . . . . 26

Wolff, R. G. . . . . . . . . . 31, 39, 48, 53

Wollenberg, H. A. . . . . . . . . . 26

Wong, K. S. . . . . . . . . . . . . . . 47

Wonn, J. W. . . . . . . . . . . . 5, 29

Wood, B. . . . . . . . . . . . . . . 40

Wood, R. D. . . . . . . . . . 37

Woods, R. D. ............ 6

Woodhouse, R. ............. 31

Woody, R. T. . . . . . . . . . 49

Woolson, W. A. . . . . . . . . . 37, 39

Work, P. L. . . . . . . . . . . 17 
Page

...............

Worthington, A. E. . . . . . . . 46

Worthington, P. F. .......... 30

Wu, C. H. . . . . . . . . . . 42

Wurzel, P. . . ........... 19

Wylie, K. M. ............

Wyllie, M. R. J. . . . . . . . . 3, 11, 47

Wyman, R. E. . . . . . . . . . . 39

$\mathbf{Y}$

Yakubson, K. L. . . . . . . . . . 37

Yemelyanov, v. A. . . . . . . . . . 37
York, P. L

Youmans, A. H. 3, 35, 36, 37

40, 43

Youngblood, w. E. . . . . . . . . 26

Yu, T. R.

Zablocki, C. J. . . . . . . . . . . 11

Zangwill, J. . . . . . . . . . . 16

Zanier, A. M. .......... 2, 4, 5, 11

Zappe, S. O. . . . . . . . . . 4
Page

Zebal, G. P. . . . . . . . . . . 28

Zeid, M. C. . . . . . . . . . 45, 46

Zemanek, J. . . . . . .

Zenor, H. M. . . . . . . . 30, 45

Zhadin, v. V. ............... 5

Zimmerman, C. W. ............ 2

Zinnow, K. P. . . . . . . . .

Zittel, R. J. . . . . . ...... 26

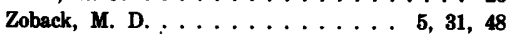

Zoback, M. L. . . ...........48

Zoeller, W. A. . . . . . . . . 3, 5, 42

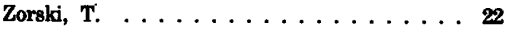

Zuber, A. . . . . . . . . $\ldots \ldots$ 




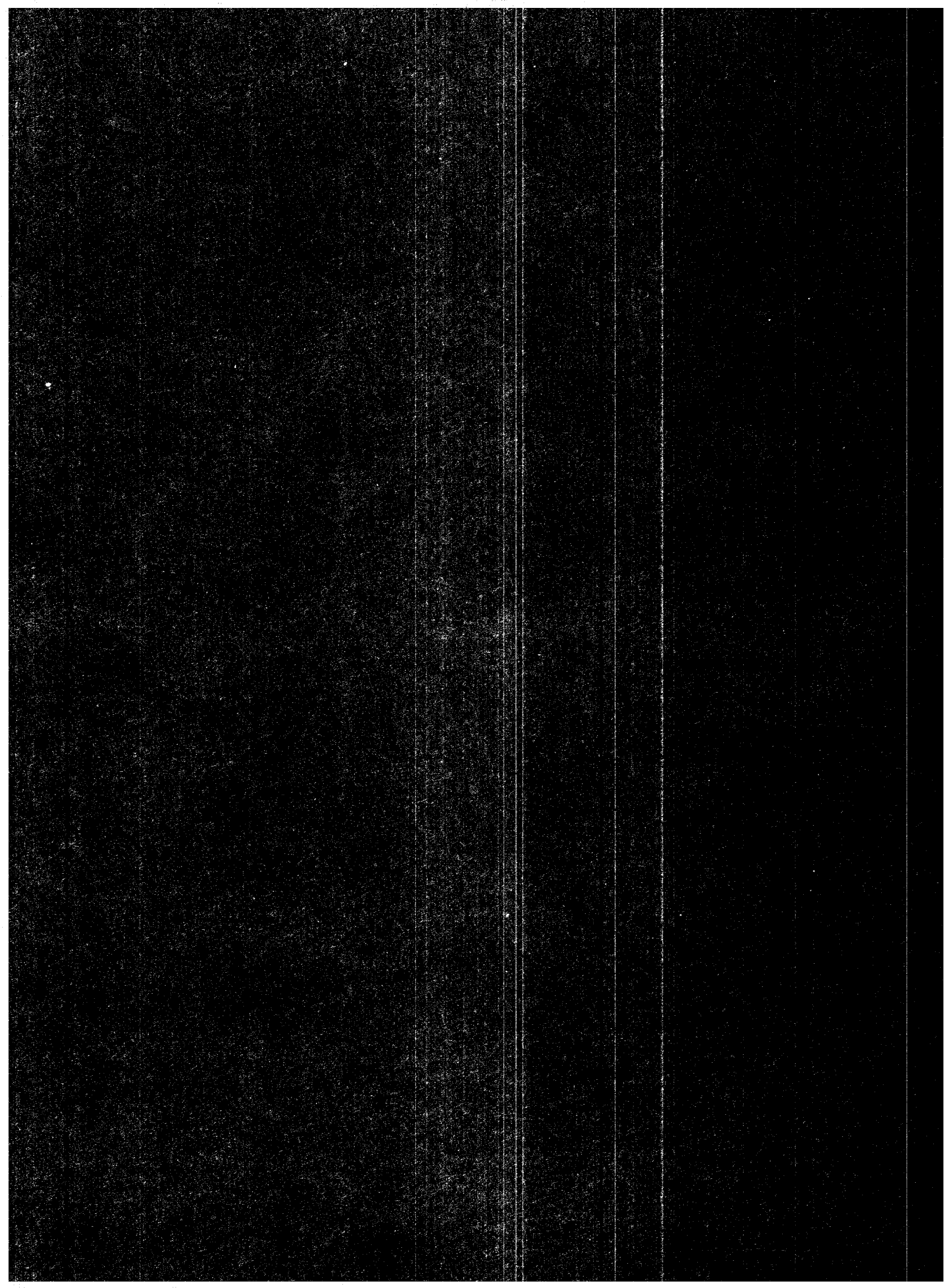


1
3

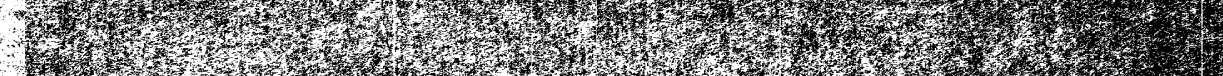

Hy

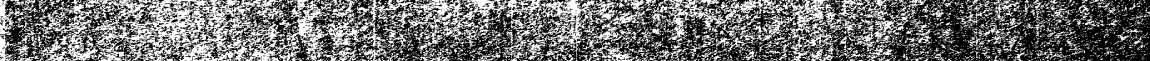

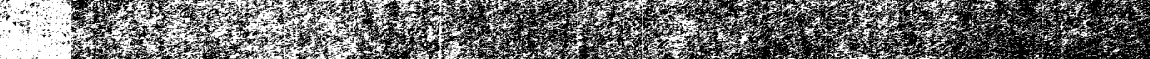

m.

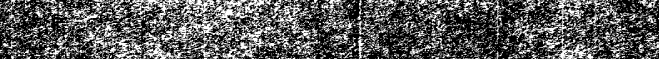

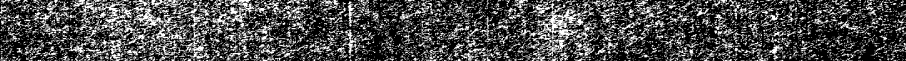

m

T.7.

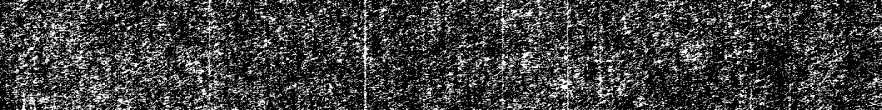

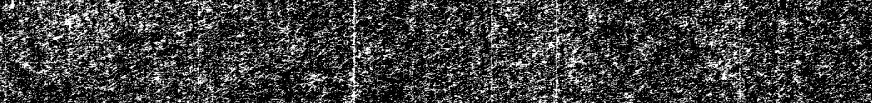

10.6.

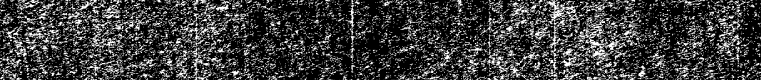

3.

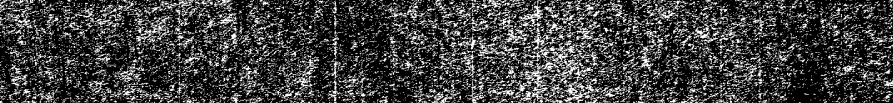

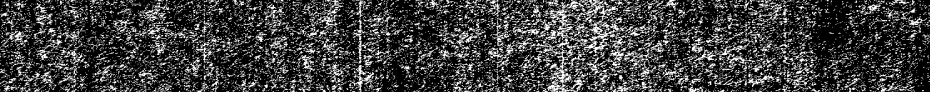

2.

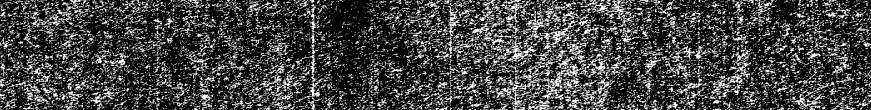

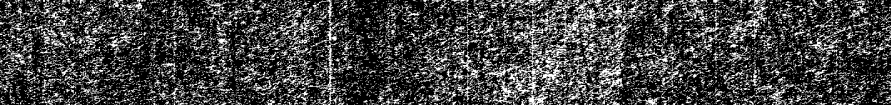

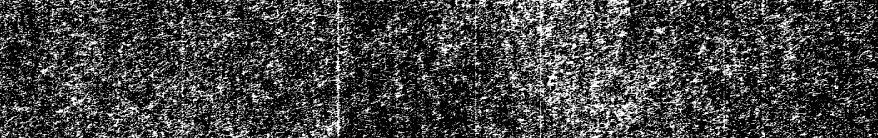

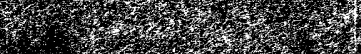

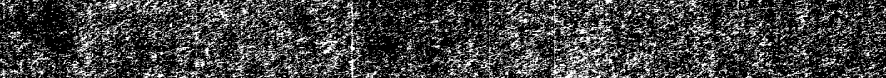

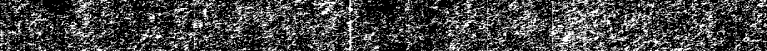

U.

I.

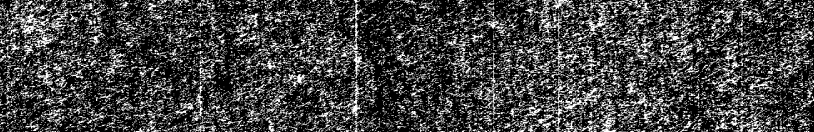

xys

H

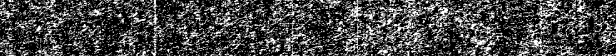

20.5.

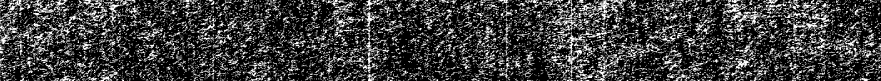

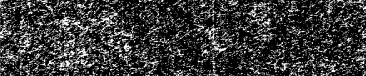

